University of Nebraska - Lincoln

DigitalCommons@University of Nebraska - Lincoln

Faculty Publications and Creative Activity, School of Art, Art History and Design

Art, Art History and Design, School of

1978

\title{
Unequal Lovers: A Study of Unequal Couples in Northern Art
}

\author{
Alison G. Stewart \\ University of Nebraska-Lincoln, astewart1@unl.edu
}

Follow this and additional works at: https://digitalcommons.unl.edu/artfacpub

Part of the History of Art, Architecture, and Archaeology Commons

Stewart, Alison G., "Unequal Lovers: A Study of Unequal Couples in Northern Art" (1978). Faculty Publications and Creative Activity, School of Art, Art History and Design. 19.

https://digitalcommons.unl.edu/artfacpub/19

This Article is brought to you for free and open access by the Art, Art History and Design, School of at DigitalCommons@University of Nebraska - Lincoln. It has been accepted for inclusion in Faculty Publications and Creative Activity, School of Art, Art History and Design by an authorized administrator of DigitalCommons@University of Nebraska - Lincoln. 


\section{Unequal Lovers}




\section{Unequal Lovers A Study of Unequal Couples in Northern Art}

\section{Alison G.Stewart}

ABARIS BOOKS •NEW YORK 


\section{Copyright 1977 by Walter L. Strauss}

International Standard Book Number 0-913870-44-7

Library of Congress Card Number 77-086221

First published 1978 by Abaris Books, Inc.

24 West 40th Street, New York, New York 10018

Printed in the United States of America

This book is sold subject to the condition that no portion shall be reproduced in any form or by any means, and that it shall not, by way of trade, be lent, resold, hired out, or otherwise disposed of without the publisher' s consent, in any form of binding or cover other than that in which it is published. 
TO MY PARENTS 


\section{CONTENTS}

Acknowledgements 9

$\begin{array}{lll}\text { Chapter } 1 \text { A Universal Theme } & 11\end{array}$

Chapter 2 Literary Sources from Plautus to Shakespeare 13

Chapter 3 Artistic Predecessors 35

Chapter 4 Symbolic and Iconographic Elements 47

$\begin{array}{lll}\text { Chapter } 5 \text { Conclusion and Interpretation } & 101\end{array}$

Notes 125

$\begin{array}{ll}\text { Handlist } & 137\end{array}$

Bibliography 183

$\begin{array}{ll}\text { Index } & 195\end{array}$ 


\section{ADDENDA AND CORRIGENDA}

line 19: change "they to "thy"

line 5: read "Fool's Caps"; line 30: delete the comma after "or"

The source of the illustration is: Berlin, Staatsbibliothek, preussischer Kulturbesitz

line 20: change "next" to "nest"; line 30: change "1549" to "1529"; line 31 : after (fig. 28) add footnote "139"; line 35: after "unsatisfied" add footnote "140". Change the date of the caption for illustration 28 to " 1529 "

line 31: after "pelf" insert "he blames both partners"

line 16: read "skillfully"

line 14: read "in the first place they [women]"

line 21: read "I will also release you from this lock"

line 23: read "Locks don't help against a woman's lust"

line 2: read "Staatliche Museen preussischer Kulturbesitz"

caption, line 2: add (?) after "Woman's"

caption: add "the woodcut has been attributed to Erhard Schoen, c. 1533"

footnote 139 becomes 140 ; footnote 140 becomes 139

add footnotes 283 thru 287 :

283: Von der Osten and Vey 1969, p. 215.

284: For the woman in profile and the five grotesque men, both in Windsor (12447R and 12495R), see Clark and Pedretti 1968, vol. 2, figs. 12447r and 12495r; vol. 1, p. 73, dates the drawing of the woman in profile to ca. 1491 and Pedretti 1957, p. 33, to ca. 1492. The Five Grotesques are placed around the same time-ca. 1490 by Popham (1945, p. 42) and ca. 1494 by Clark and Pedretti (1968, vol. 1, p. 85). For interpretation and a copy after the Five Grotesques, see Gombrich 1976, p. 71 (and fig. 183), and Bia Xostocki 1959, pl. 4.

285: Larsen 1950, p. 174, and Krönig 1950, pp. 174, and 10f., n. 24.

286: Major and Gradmann [1942] , p. 21, no. 38, and fig. 38.

287: Opinions expressed were by Wolfgang Eckhardt in Hamburg and Johann Michael Fritz, Karlsruhe, based on photocopies of the medallion. Their cooperation is greatly appreciated. I would like to thank Mark Zucker for bringing this example to my attention.

line 4: delete "N"

line 6: read "Quinten"

line 3: (The Crayfish Master)

text line 9 and footnote 287

line 1: Altniederländische Schaubühne; line 23: read Meckenem; line 25: read Hälfte

line 15: italienische

line 19: Einflüsse

line 35: Schembart; line 47: delete $s t$

line 36: $d . \ddot{A}$.

right, line 23: Dream of the Idler

left, line 5: Melencolia I

right, line 12: Schwankerzählungen 


\section{ACKNOWLEDGEMENTS}

My study of Unequal Lovers began at Queens College of the City University of New York as a master's thesis, completed in September 1976. It was partially supported by a graduate assistantship from the college. The present work revises, updates, and adds to the thesis, especially in the literary and concluding chapters. Revision for publication took place primarily in the fall of 1977 while I was completing course work at Columbia University, during which time my studies were supported by a University fellowship. A grant from the Photographic Collection of Columbia University supported the acquisition of photographs for this book.

I would like to thank the many friends and colleagues who have given their advice and shown interest in this project, among them: Mark J. Zucker, University of Wisconsin at Milwaukee, for suggesting the topic and for his helpful discussions during the initial stage of this study; Leonard J. Slatkes, my thesis advisor, above all for his untiring willingness to talk over ideas and for suggesting that I take advantage of European collections, which formed an integral part of this work; Keith P.F. Moxey, University of Virginia, Charlottesville, especially for generously providing many examples of Unequal Lovers in Netherlandish literature, cited individually below; and Christiane Andersson, my advisor at Columbia University, for her expertise in German graphics and her many helpful suggestions, in particular her extensive revisions of the thesis text. Special thanks to Walter Strauss for his enthusiastic support of the project, for accepting an essentially unfinished manuscript and tirelessly revising it, and above all for making possible its publication. Laurie Sucher's sympathetic and expert editorial function turned many a less than poetic phrase into what you see before you. Finally to my parents for their unfailing faith, support and interest, and to Laura, who never ceases to amaze me with her understanding and friendship. 


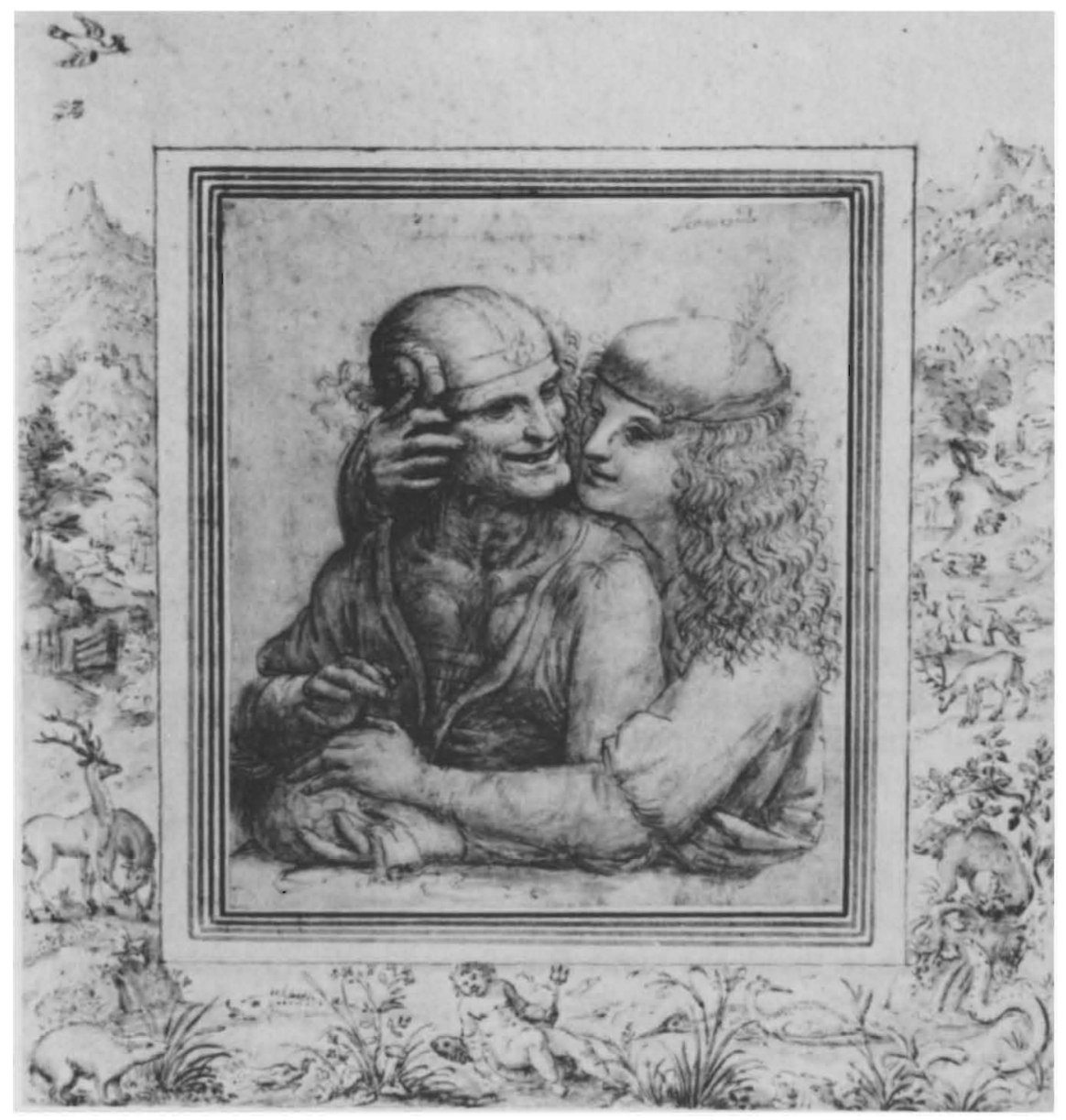

Jakob Hoefnagel (d. 1630), Old Woman with Young Man (after Leonardo da Vinci) 


\section{Chapter 1}

\section{A Universal Theme}

David Hume once wrote that humanity is "so much the same in all times and places, that history informs us of nothing new or strange in this particular. Its chief use is only to discover the constant and universal principles of human nature." I

Love between the old and the young is a theme that has interested artists and audiences since antiquity, when Plautus (d. 184 B.C.), working after Greek originals, set down in writing the first representations of this theme that have come down to us.

That it is a "constant and universal principle of human nature" is suggested not only by its inclusion in the folk literature of Europe and Asia, ${ }^{2}$ but also by the existence of artifacts like a pre-Columbian whistle which dates between 600 and 900 A.D. ${ }^{3}$ The theme was highly popular in the literature of the late Middle Ages and the Renaissance, and numerous representations of it appear in the visual arts from the Renaissance to the Baroque. Unequal Lovers became popular in another guise during the late seventeenth century in Restoration plays such as those by William Wycherley and William Congreve. ${ }^{4}$

Nor is the twentieth century excluded from this historical continuum. Jokes and cartoons center on the theme. Picasso's Courtship, a drawing of 1905-6 (New York, Guggenheim Museum), and movies like Harold and Maude (which dealt with the relationship of an old woman and a young man, based on love, not money) take it up as well.

The old woman-young man combination still makes news:

FORTALEZA, Brazil (AP), December 10, 1975. Cosmo Vidal de Silva, 22, and Rozena Borroso Lima, 71, were married yesterday in this northern port city.

The bride has nine children, 47 grandchildren and six great-grandchildren. Her youngest child is 32 and her oldest grandchild is 35 . 
Unequal Couples are sometimes designated as Ill-Matched or Ill-Assorted Couples, though the term Unequal Couples is used in this study. On the other hand, the term Unequal Lovers encompasses all representations of the theme, and includes both Unequal Couples and Love Triangles.

The scope of this work is primarily the fifteenth and early sixteenth centuries, a period in which conditions were such that the Unequal Lovers theme attained a new popularity and was first depicted as an independent representation in the visual arts. This popularity was most pronounced in northern Europe, especially Germany, and it is this greatest period of German efflorescence (ca. 1470-1535) that delineates the time span covered here. The invention of engraving and the other graphic arts; the growth of the middle class, for whom money took on a new accessibility; the invention of the printing press, which of course revolutionized communications and the spread of ideas; the increasing interest in secular and satirical subjects: each of these related factors accounts partially for the particular appeal of this theme to the audience of the time. It is therefore a fruitful period for the study of the Unequal Lovers theme, and we shall limit ourselves, at least in the visual arts, to it.

Few authors have addressed the theme. Raimond van Marle and Anton Pigler listed numerous representations in the Renaissance and Baroque. ${ }^{6}$ Paul Wescher (1938) and Lawrence Silver (1974), with greater insight and depth, have dealt with individual representations. ${ }^{7}$ Only W. A. Coupe (1967) examined the subject more comprehensively. ${ }^{8}$

This study will attempt to catalogue for the first time the numerous representations that appeared around 1500 (see Handlist, p.138), and deal with the following questions: How popular were Unequal Lovers in the literature and visual arts of that time? Does contemporary literature help clarify the significance of these representations? What were the meanings of these works of art? And who were their audience? 


\section{Chapter 2}

\section{Literary Sources from Plautus to Shakespeare}

\section{Plautus}

The history of Unequal Lovers in literature is a long one. As early as the third century B.C. the Roman comic poet Titus Maccius Plautus (ca. 251-184 B.C.) wrote at least four comedies dealing with old men who unsuccessfully court young women. ${ }^{9}$ In The Merchant, which is referred to in Erasmus's Praise of Folly, the sixty-year-old Demipho falls madly in love with Pasicompsa, the young mistress whom his son Charinus has acquired on a business trip to Rhodes. ${ }^{10}$ Confusion ensues when a helpful neighbor harbors the girl in his house only to be surprised by his own wife's premature return from the country, and her (natural) conclusion that the harlot is her husband's.

The play closes with an address to the audience by Eutychus, the neighbor's son. He proclaims that any man over the age of sixty, regardless of marital status, who "consorts with harlots ... shall be considered stupid," and will come running for help only after the harlots have "wasted his property and possessions." Old Demipho is described at other times as a "dirty old fellow [who] tried to make her [Pasicompsa]," and Demipho calls himself "an absolute madman" because of his love for the prostitute. Yet another aside to the audience underlines the absurdity of old men's love for young women, as Demipho is called "a senile, decrepit old man [who] is just as good a lover as a mural."

In addition to the stupidity, lustfulness, and absurdity attributed to the old man, this rendition of the theme of Unequal Love partakes of the fifteenth-century attitude that carnal love has ruined many a man. The young lover, Charinus, goes even further when he states that love "is usually accompanied by all these faults: care, sorrow, and excessive luxury . . . stupidity, folly, and thoughtlessness, insane inconsiderateness, immoderation, impudence, lust." 


\section{Hroswitha of Gandersheim}

Over one thousand years passed between the appearance of Plautus's comedies and the next Unequal Couple in western literature which we shall consider. Hroswitha of Gandersheim (ca. 935-ca. 1002), working in the Benedictine monastery in the Saxon town of that name, penned Paphnutius around the middle of the tenth century. ${ }^{11}$ This drama, one of six, centers around the attempts of the old hermit Paphnutius to reform the ways of his former courtesan Thais. (Her name seems to be borrowed from an Athenian prostitute who lived during the time of Alexander the Great.)

Paphnutius is unlike the lusty old men in Plautus's comedies. His affection for Thais is obvious. The sense of decorum and elevation of virtue employed by the dramatist, who considered chastity a great virtue, seems to differentiate the early medieval treatment of the theme from the more raucous and satirical renditions of Plautus and his later revivers. Where Plautus's writings center around a basically humorous and chaotic situation that reveals the inevitable failure of Unequal Love relationships, Hroswitha's deals with an old man's desire to save a young woman from her sordid lifestyle. Hroswitha's message is clearly a moral one, though with Plautus the moral or message-if there is one-is hidden amid the fun.

\section{Marie de France}

Among the first stories in the medieval chivalrous vein of "love for love's sake" are the short poems or lays written in the twelfth century by Marie de France. ${ }^{12}$ Best known for her lays and fables, she lived at the time of Henry II, who was, presumably, the "noble king" to whom her lays are dedicated in their prologue. Marie wrote for an audience that included castlefolk, nobles, and particularly ladies. Sometime after the middle of the twelfth century she left Normandy to settle in England, where she produced translations of Aesop's fables in English and French. ${ }^{13}$

The popularity of Marie's works is evident from their inclusion in no less than five manuscripts dating from the thirteenth to the fourteenth century. ${ }^{14}$ Among these works was the "Lay of Yonec," which tells the story of an old man who marries a young and beautiful woman and then keeps her secluded in a tower. ${ }^{15}$ The young woman is not happy with her elderly mate, who has failed in his minimal marital obligations. Bemoaning her fate, she cries, "Very greatly are my parents and my kin to blame for giving me to this jealous old man, and making us one flesh." Marie, as narrator, concurs in one of the morals of the story: "Great was their sin who married the maiden to this aged man."

Locked up alone in her tower, the young wife considers the fact that other women get themselves lovers and wonders whether she should also. To her surprise, a hawk flies through the open window of her chamber, and is suddenly transformed into a beautiful young knight who professes his love for her. Happy at last, she continues to see the knight, who comes to her in 
this same guise until her old husband, suspicious of her newly found happiness, discovers her devotion to the bird and has it shot. Her sorrow is somewhat assuaged, however, by the child she has conceived with the knight, a boy named Yonec. We soon discover that the maiden's lover was actually a king whose court now lacks a ruler. Yonec learns the truth of the circumstances surrounding his father's death when his mother faints atop his father's grave. The avenging Yonec then strikes his mother's elderly husband, cuts off his head with chivalrous revenge, and claims the throne.

The story, then, centers around a Love Triangle that does not involve money. One of its messages may well be that old men who wish to marry young women and keep them locked up delude themselves, for if a woman so desires, she will discover a way to extricate herself from an unpleasant situation. Marie imparts a tone of tolerance and acceptance to her account of this infidelity because the motivating factor is love, an element that was noticeably absent from the young woman's marriage. The real moral of the story may be that "Love is only lasting between like and like," as the author declares in her "Lay of Equitan.",16

\section{Roman de la Rose}

This great thirteenth-century work, possibly the most popular poem of the Middle Ages, ${ }^{17}$ not surprisingly appears to glorify love. ${ }^{18}$ Begun around 1237 by Guillaume de Lorris and completed some forty years later by Jean de Meun, the Roman mentions mercenary love, another way of being unequally matched, but ignores the subject of love between unequal ages. In chapter 22, "Reason Contrasts Youth and Old Age," Jean de Meun writes:

Youth leads a man to folly and debauch, To ribaldry, outrage, and lechery, ... . But Age retrieves from folly ... .

For no one loves or prizes Age enough.

Further on in the chapter the author speaks of

Unworthy whores who sell themselves for coin And whose vile life unfits them for all joy. She who would yield herself for any price Cannot do good. One should have naught to do With any woman who her body sells . . . Most wretchedly deceived is one who thinks That such a woman loves him, just because She smiles and feasts him, calling him her dear...

But let them guard

Against Love's follies, which enflame and burn The heart, and let their love unselfish be; For selfishness incites false hearts to greed. True love should have its birth from noble heart, Not of the carnal will that masters men. ${ }^{19}$ 
The poet thus touches on the two most common characteristics of Unequal Love-male carnal lust and the mercenary intentions of young women-as two of love's follies, an idea that is prominent in representations of Unequal Lovers in the visual arts some two hundred years later. Lust and money were not acceptable reasons for affairs of the heart where love should preside. Nevertheless, the tone of the poem informs the reader of a new literary tendency toward satire. Instead of stressing pure love, as do the lays by Marie de France, the Roman emphasizes the more lascivious, titillating, and mercenary aspects, using moral admonitions as an excuse for mentioning them at all.

\section{Exempla}

Moralizing anecdotes called exempla were used by the mendicant orders in the thirteenth century to spice up their sermons when their parishioners' interest was clearly flagging. The themes of the exempla derived not only from everyday life, but also from epics and fables, popular tradition, and literary sources. Alphabetized compendia of exempla became available to the clergy in the second half of the thirteenth century. ${ }^{20}$ Franciscans and Dominicans were now preaching in the vernacular, indicating that the pulpit had become a source of learning and refinement for those lower and middle sectors of society that had no access to the romantic minstrelsy of the nobility and aristocracy. Through the pulpit, the tradition of a serio-comic satire grew up in English popular verse-a tradition which has persisted down to modern times. ${ }^{21}$ Exempla undoubtedly became well known to the medieval person-on-the-street, since they were preached in streets, taverns, marketplaces and, of course, churches, where up to five of these anecdotes were recited after each sermon. ${ }^{22}$

The use of exempla was popular until about the mid-fourteenth century when mendicants' reputations began to wane. At that time a few references to marrying women, even old women, for money or lust occur in English exempla. The following dates from around 1360:

\footnotetext{
But money wedd hem wyvys for her worldly goodes, for her grete kynne, other for ther fleschely lust: . . . Som had lever to take an olde wedow, though sche be ful lothelyche and never schall have cheldren. And, fro the tyme that he hathe the mocke that he wedded her for, and felethe her breth foule stynkynge and her eyen blered, scabbed and febyll, as old wommen buthe, then they spend a-pon strompettes that evyll-getyn goodes. ... It seemeth, then, they wedden the goodes more than the woman. 23
}

By all indications, the rather unpleasant description of the old wife and the idea of wedding an old woman for her possessions were very popular, since they are also found in later German works discussed below.

Somewhat later, around 1370, the English Dominican John Bromyard devoted a chapter of his Summa Predicantium to marriage, yet only a small 
part of it is devoted to the dignity and worth of that institution. Drawn mostly from thirteenth-century sources, the chapter mentions the deleterious effects of marrying for money or lust, without, however, referring to differences in age:

Daily experience suffices to show that those who wed for beauty, for sensual pleasure or for riches swiftly lose peace of heart and rest of body, and are changed into states of the greatest hatreds, discords, blows and adulteries. 24

Less than a century later, the idea of marrying for money could be found in an Italian sermon entitled "Wives and Widows," delivered by St. Bernardino in the public square of Siena in August and September of 1427:

Consider now and think of such as choose their wives for other reasons [than goodness]; for example, of such as take a wife for her good dowry's sake; if then they be affianced, and the dowry come not, what (thinkest thou) shall be the love betwixt them both? A love stuck together with spittle! . . . Whereof I say to you, lady, take not for thine husband the man who would fain take thy money and not thy self; take rather him who would take thee first and afterwards they money with thee; for if he love thy money more than thee, thou art in evil case...25

The close contact between France and England at this time, and the availability of Franco-Flemish manuscripts in the Netherlands, as well as the appearance of similar sermon themes in England and Italy, suggest that both the illustrations and the content of manuscripts were fairly homogenous throughout Europe in the thirteenth and fourteenth centuries. Undoubtedly this also applied to the theme of Unequal Lovers.

\section{Gesta Romanorum}

Possibly the most popular stories of the late Middle Ages were compiled in the Gesta romanorum, drawn from the history and legends of Rome, later stories of the lives of the saints, anecdotes, and probably even the moralizing anecdotes or exempla of Jacques de Vitry (died ca. 1240) and Odo of Cheuton. ${ }^{26}$ These colorful tales were originally intended for preachers who would draw on their symbolic application of moral and religious virtue, at the same time enlivening their sermons. The tales were probably compiled by 1300 if not much earlier, and the author was probably English although possibly German. The earliest extant manuscript of the Gesta romanorum, in fact, is English and was written in Latin in 1342. ${ }^{27}$ Soon thereafter the Gesta became quite popular and were found in numerous manuscripts, mostly in Latin, until the early sixteenth century.

The Gesta "Of Worldly Glory and Luxury" seems to derive from Marie de France's "Lay of Laustic." Also called "The Old and the Young 
Knight," this tale recounts the conflict between a wealthy old knight who marries a young maid for her beauty, and a poor young knight who marries an old woman for her wealth. Needless to say, the two young people fall in love. The young knight kills the old one, and when the former's old wife dies the two young lovers are united and live happily ever after. The theme or moral of this tale seems again to be that lovers of the same age form not only the happiest, but also the most natural couples.

\section{Sotterniën}

The dramatic counterparts to exempla in the Netherlands in the fourteenth century were the sotternien, satirical works performed at the end of mystery plays, abele plays, which dealt with love, and other dramatic works. The sotternie is the oldest form of the Netherlandish farce; it is short in length and presents a colorful slice of folklore. The subjects of the sotterniën, like those of the exempla, were drawn from domestic life and sometimes include relations between the sexes, especially faithless and cunning females who deceive their husbands and struggle for power within the home. ${ }^{28}$

Unequal Love would certainly not be out of place in the sotternie. Die Buskenblaser is a sotternie in which an old man in an unequal marriage pays another man handsomely, with a full purse he has obtained by selling his good cow. ${ }^{29}$ This he does because he has been promised youthfulness, a nice voice, beauty and the ability to satisfy his young wife. When the old man blows on the busken or small can, the miraculous transformation is expected to take place. Instead, the old man makes a fool of himself and receives only ridicule from his wife for his senseless behavior and foolish expectations.

\section{Boccaccio, "The Decameron"}

With Boccaccio the theme of Unequal Love takes a turn toward the comical, recalling Plautus's plays rather than the chivalrous verse of Hroswitha and Marie de France, or the more serious although satirical exempla. Nevertheless, there are similarities between Marie de France's "Lay of Yonec" and a passage from Boccaccio's Decameron that was probably begun by $1350 .{ }^{30}$

In Boccaccio's story (Second Day, Tenth Story) a wealthy old judge, Messer Ricciardo di Chinzica, marries a young and beautiful woman whom he has taken great pains to find, but rather disappoints her, even on their wedding night when "he only managed to come at her once in order to consummate the marriage, and even then he very nearly fell out of the game before it was over." The judge is obviously quite mistaken in his belief that "he could satisfy a wife with those same talents that he brought to his studies." He uses saints' days and indeed any religious holiday as an excuse for not sleeping with his wife. One day, while the gentlefolk are fishing, their boats go adrift and the ladies' boat is overtaken by the pirate Paganino. It comes as no surprise that the pirate abducts Ricciardo's lovely wife. 
Eventually landing in Monaco, the two are blissfully happy, the pirate providing what Ricciardo had so anxiously avoided. After futile attempts to recover his wife, the old man finally locates her. She acknowledges him only after he asserts that he loves and cares for her. She points out that he has never cared for her womanly desires and that he

should certainly have had the gumption to realize that a fresh and vigorous young woman like myself needs something more than food and clothes, even if modesty forbids her to say so. And you know how little of that you provided.

Defending her captor, who has treated her with kindness and affection, she also tells Ricciardo, "I only wish my parents had displayed an equal regard for it [my honor] when they handed me over to you!' She bids him be off without her, and he complies, admitting through the narrator "how foolish he had been to take a young wife when he was so impotent." He soon dies and his wife and Paganino marry. Thus it is love that triumphs, not marriage to an impotent, older partner. Boccaccio adds humor and satire, thereby departing from the earlier, more overtly moral approach and coming closer to Plautus.

In "The Pear Tree Tale," which goes back at least to the Italian novellino prose novels of about $1300,{ }^{31}$ Boccaccio again tolerates the physical union of people in love, just as he does not, here and in at least one other instance, seem to censure extramarital relations. ${ }^{32}$ Young Lydia marries old Nicostratus, who does not fulfill her sexual desires-desires which Lydia effectively communicates to young Pyrrhus. One day as the unequal couple and the young man are strolling in Nicostratus's garden, Lydia feigns illness and retires. Pyrrhus climbs a pear tree to pick some fruit for her, and, from the tree, exclaims to Nicostratus that he sees two people making love! When Nicostratus climbs the tree himself, he finds that the two are none other than Pyrrhus and Lydia. The tree plays tricks on the eyes, and the old man is both a cuckold and a fool. In both of these Decameron stories, the old man's foolishness consists in first wedding a much younger wife, and then in imagining that she will remain faithful despite his inability to satisfy her. In "The Pear Tree Tale," Nicostratus's foolishness is compounded by the cunning of the young wife and her willing accomplice.

This story includes nearly all of the necessary components of the theme of the Unequal Couple or the Love Triangle: a well-to-do old man, his young wife, and her young lover. (Although Nicostratus's financial situation is never explicitly described, the implication is that he possesses sufficient funds to marry a young and attractive woman.)

$$
\text { Chaucer, "The Canterbury Tales" }
$$

Boccaccio's pear tree tale may have been known to Chaucer, who made use of it for the ending of the "Merchant's Tale" in his Canterbury Tales, 
probably written in the 1390s. Sixty-year-old January, "white-haired and old, and almost, God knows, at the brink of his grave," marries the beautiful and young May, of low estate and age twenty at most. ${ }^{33}$ Despite January's exceedingly affectionate nature, May falls for the young Damian, who returns her feelings. January becomes blind, but his sight will be restored, according to legend, if his wife and her lover dally in a tree. Only too willing to help with so pleasant a remedy, but quite unwilling to let January in on their game at first, May and Damian climb into the pear tree. in January's enclosed garden while the blind, unaware old man stands on the ground, his arms encircling the base of the tree to ensure that no man climbs into it with his wife, who is supposed to be gathering fruit. As he hears noises, he regains his eyesight. When he accuses his wife of being a harlot, he must forgive all as she explains that she was only trying to restore her poor husband's eyesight.

At the beginning of this tale the merchant avows that

It is a glorious thing to take a wife, Especially when a man is old and hoary:

Then a wife is the best part of his treasure;

Then he should take a young and beautiful wife

On whom he can engender an heir

And lead his life in joy and in delights.

Yet further on in the tale the old man is warned, "if you take a wife into your keeping, you may very easily become a cuckold . . . [especially since] the youngest man in this group has enough trouble to keep his wife to himself."

Later versions of this tale are found in Germany in the fifteenth century and will be discussed below.

The Book of the Chevalier de la Tour Landry

Written in 1371 and popular throughout the Renaissance in England, France and Germany, this manual on comportment was penned by the Chevalier de la Tour Landry for his three daughters. ${ }^{34}$ As a soldier and gentleman-writer, the author composed a frank, tender and deeply pious book using examples from contemporary tales, the classics and the Bible to encourage such virtues as charity, chastity, courtesy, modesty, obedience, piety and temperance. Known in Germany as the Ritter vom Turn, it was provided with forty-five woodcuts by Dürer for the edition published in Basel by Michael Furter in 1493. ${ }^{35}$

In chapter 62, the chevalier recounts the Old Testament story of Judah and Tamar as a cautionary tale about marital infidelity. This story has also been suggested as an explanation for Dürer's engraved Unequal Couple (fig. 1). ${ }^{36}$ Tamar lured her aged father-in-law Judah to her in order to continue the family line after the death of her evil husband Henam. Despite her good 


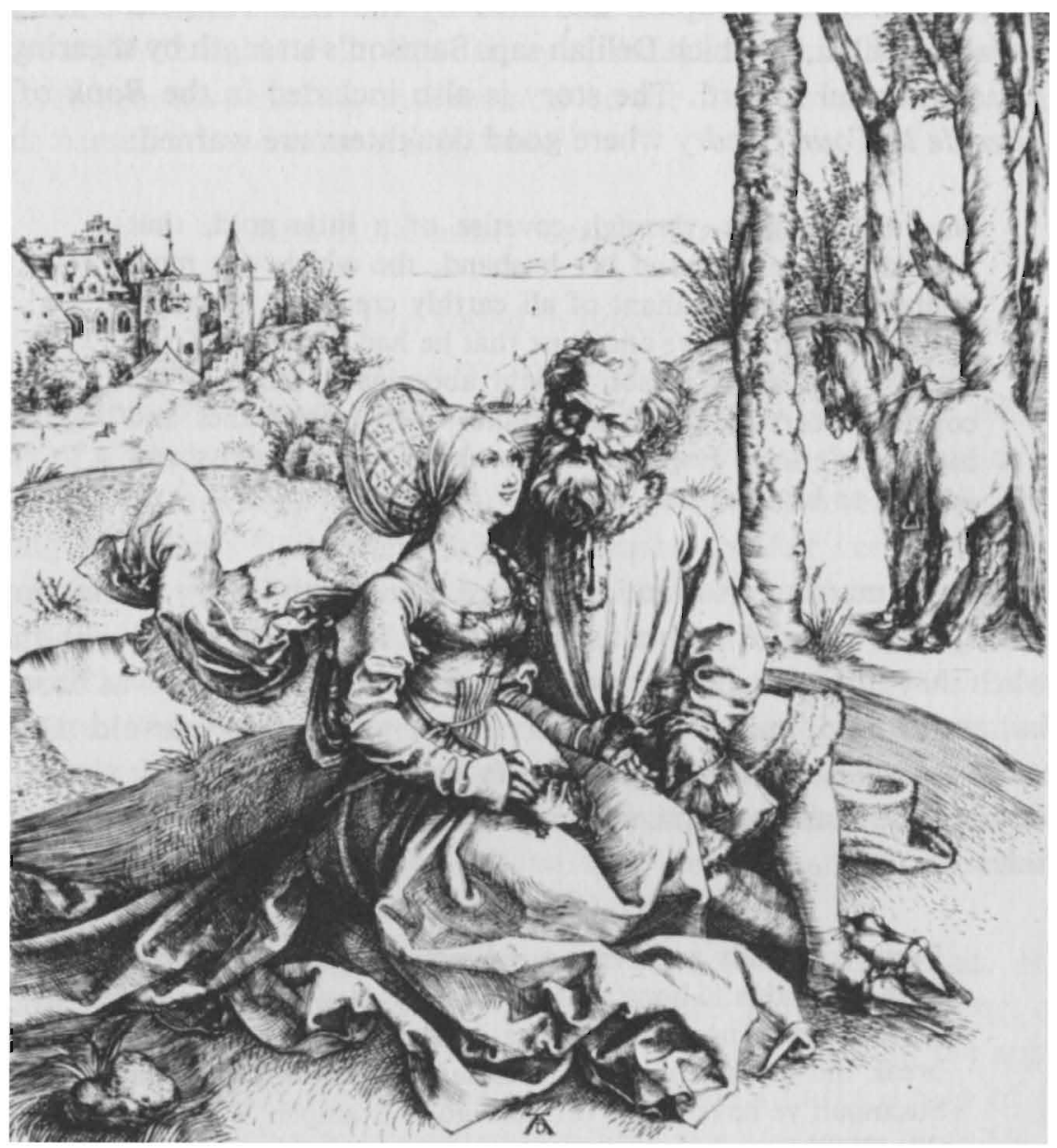

1. Albrecht Dürer, Old Man and Young Woman, ca. 1495, engraving

intentions, only bad came of it. Tamar gave birth to two children "wherefore many tribulations and evils befell afterward. For the children that be not of true marriage, they be they by whom the great heritages and ancestry be lost." 37 After citing a contemporary example, the chapter concludes:

And therefore beware, daughters, of this adultery, and that ye take no man save him that is ordained you by sacrament of marriage, and keepeth and holdeth him to you truly. 38

The moral clearly warns against infidelity. The specific example of Judah and Tamar, however, cautions against incest, which of course may well involve partners of unequal ages. 
The association of money and deceitful love is shared by representations of Unequal couples, and also by the Old Testament story of Samson and Delilah, in which Delilah saps Samson's strength by shearing his hair for a financial reward. The story is also included in the Book of the Chevalier de la Tour Landry where good daughters are warned:

Now behold how, through covetise of a little gold, that wicked woman betrayed her husband, the which was most doubted and most valiant of all earthly creatures, notwithstanding the great love and trust that he had unto her. Truly covetise is in every person a right abominable sin. For the covetous heart dare well undertake to do great follies and inconveniences. For covetise maketh ... maidens and widows to be strumpets. ${ }^{39}$

Fidelity in marriage is mentioned once more in the story of Susannah and the Elders, who spied on her as she bathed. Refusing to sleep with them even when they threatened to accuse her of infidelity, Susannah was brought to trial and found guilty of adultery. The wise, five-year-old Daniel suggested that the Elders be made to testify separately. When their testimony did not jibe, the court recognized Susannah's innocence. La Tour Landry concludes:

Every good lady and every good woman ought evermore to have her faith and hope in God and in his law, nor for worldly joy, nor pain, nor dread of death, to consent to sin, nor to break the sacrament of her marriage, as by this good lady Susannah ye have heard fair and good example. Wherefore, fair daughters, I pray you that ye withhold this example in your heart evermore. 40

Marital fidelity is so important to the author that he prefers death to adultery. Marriage is even more important than love, the main consideration in the tales of Marie de France, Boccaccio and Chaucer.

\section{Other Fourteenth-Century Sources}

There are other fourteenth-century sources that involve an old man who marries a young woman. Eustache Deschamp's (died 1406?) Miroir de Mariage includes comments on the pros and cons of taking a wife, as do the opening words of the "Merchant's Tale" (see p.20).4l Elderly Franc Voulois describes the type of woman he would like to marry: kind, hard-working, chaste, meek and young-between fifteen and twenty years old! 42

In Boccaccio's Ameto an old man also takes a young wife, though here the description of the old man is much like that of January in the "Merchant's Tale." Agapes longs for a beautiful, young husband but 
instead is married to a rich old man who is described as a withered stag. His sparse white hair, thick stubbly beard and flabby neck are just as repulsive to his young wife as his teeth, lips and eyes, though it is his nocturnal snoring and fruitless love-making that seem to be the final straw for Agapes, who finds herself a handsome young man. 43

\section{Fifteenth-Century German Manuscripts}

The fruit tree theme, first found in Boccaccio's Decameron and later in Chaucer's Canterbury Tales, also occurs in two fifteenth-century German manuscripts. Von einem plinten, a tale dating around $1425-76,{ }^{44}$ relates the story of a blind, sixty-year-old man married to a young woman described as nit sere alt ("not very old"). As in the Boccaccio-Chaucer renditions, the young wife wants fruit from a tree and climbs up after her student-friend. While in the tree she happily enjoys the company of her partner, as her husband obligingly guards against such horseplay by wrapping his arms around the trunk of the tree. New, however, is the addition of St. Peter and the Lord. Passing by the tree and seeing the improper behavior of the wife, the Lord restores the dotard's eyesight. When confronted, his clever mate explains her actions as the means by which she was hoping to restore her husband's vision. Grateful for this miracle, her husband thanks both his wife and the student for their thoughtful deed! 45

The blind old man-fruit tree story was quite widespread. It also appeared in a Low German manuscript that dates from the last part of the century. ${ }^{46}$ As in the tale just cited, the fruit is that of the Fall, the apple. A similar tale is also related in Heinrich Steinhöwel's Latin Aesop of about 1476 or 1477 , which was translated into French a few years later. ${ }^{47}$

The existence of a Russian version of this story that probably goes back to the Middle Ages, ${ }^{48}$ an Italian jest by Lodovico Domenichi probably collected about $1478,{ }^{49}$ and a French account of 1480 by Julien Macho or Julien des Augustins, which is mostly a translation of Steinhöwel's Latin Aesop, 50 suggest that the fruit tree tale was well known in Europe in the fifteenth century.

In none of these is the old man described as rich, though a young woman's marriage to an old man probably implied that he had some wealth. The old man is specifically termed rich only in a version in the Italian novellino prose tales of about $1300^{51}$ which predate even Boccaccio's Decameron.

\section{Carnival Play}

A fifteenth-century carnival play (Fastnachtspiel) entitled Vom Heiraten Spil ("A Play About Marriage") ${ }^{52}$ offers an unusual slant to the presentation of Unequal Love. It departs from earlier examples by the inclusion of obscene description, and by its division into blocks of dialogue 
suggesting contemporary ideas and expressions. Written in verse, like all the German examples cited above, the play begins with a peasant who addresses the host or innkeeper and introduces his nine young male companions who "have little wisdom to spare" and who tell us a little about their marital affairs. The first man declares that he wanted to marry a young woman but was beaten to it by a weak and misshapen old man who is "like a ridden-out horse ... [and] is worthless at night in bed." 53 Youth paired with youth, we are told, is better than youth paired with wealthy old age, since a young man can at least satisfy his young wife's lust.

The second man proclaims himself a silly young fool who is desired by an old woman. Despite his desire to marry, young maidens run away from him because he had once "geigen gespillt"' [fiddled], a euphemism for illicit sexual activity, illustrated in a drawing by Urs Graf (fig. 2).

The sixth man is also desired by an old woman who has proposed to. him. He gives an obscene description of her mouth ("Als in ain russigs arsloch"), and a crude one of her breasts-which fall like two empty saddlebags ("So storzen ir di milchflaschen,/Reht samm zwu lere sateltaschen").

Spruch

A more folksy type of German literary genre is the Spruch, a saying or long poem that was intended to be sung. The following lines have been taken from one and may have even been known around 1500 through word of mouth, as Anton Springer has suggested to explain the subject of Dürer's engraved Unequal Couple (fig. 1):

Oh, the cunning of woman, how diverse

Are your surprises and your power

To the one who experiences your spiteful trick! . . .

The wild youths want to tame you

The old fools want to lame you, with their purses. ${ }^{54}$

\section{French Song}

The French also set Unequal Lovers to music. Included in a very popular class of song called Maumariée, or, "Of Those Badly Married," is a Love Triangle in which a young woman decries her parents for marrying her to an old man. She professes love for another, undoubtedly a man closer to her own age. ${ }^{55}$

Humorous Tales

The writers of humorous tales or Schwankerzählungen have preserved carnival plays for us through their works. ${ }^{56}$ One of these stories, probably from the fifteenth century, is entitled Die Buhlschaft auf dem Baume, ${ }^{57}$ 


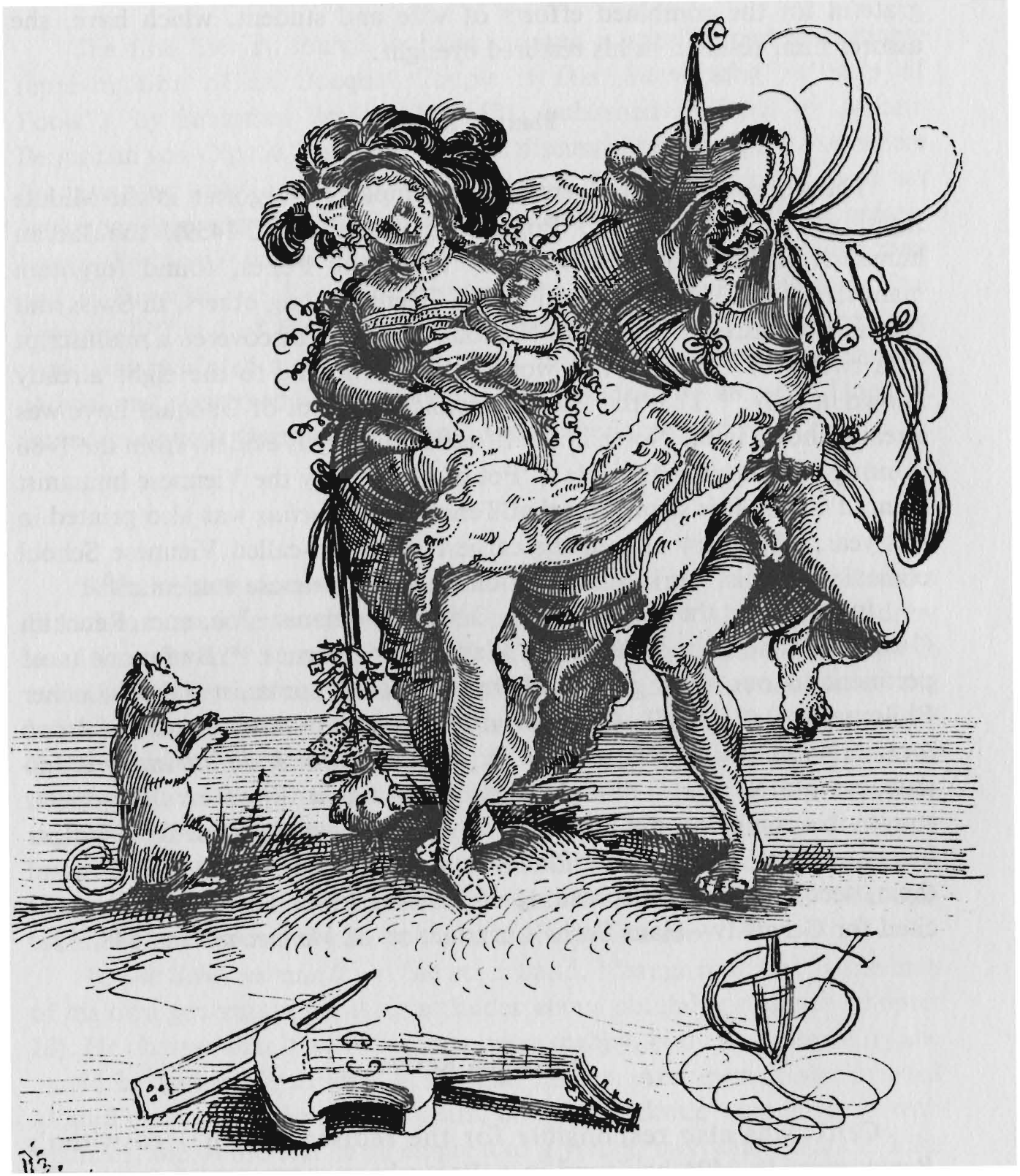

2. Urs Graf, Lustful Old Fool and Woman with Baby: Allegory of Fiddling, drawing, Basel, Kupferstichkabinett

which loosely translates as " "Love' in the Tree." Again, it deals with the fruit tree tale, possibly reflecting a lost carnival play of the theme. It is interesting to note that the blind old man tries to keep his young wife faithful by placing her thighs in an iron halter, or what we would call today a chastity belt. Despite his efforts, the young woman and the student do their will in the tree as in the earlier accounts, and again St. Peter and the Lord walk by. The old man's sight is restored and he accuses his wife of being a whore 
("Hure"), but she turns the situation around so that her husband is actually grateful for the combined efforts of wife and student, which have, she assures him, resulted in his restored eyesight.

\section{Plautus Revival}

The works of Plautus were almost completely forgotten in the Middle Ages, yet as early as 1415 Poggio Bracciolini (1380-1459), the Italian humanist and scholar, and secretary to several Popes, found forgotten manuscripts by Plautus, Lucretius and Cicero, among others, in Swiss and German monasteries. ${ }^{58}$ In 1429 Nicholas of Treves discovered a manuscript with twelve of Plautus's lost works, thereby adding to the eight already known in Italy. ${ }^{59}$ That the Plautine comic treatment of Unequal Love was already known in the North in the fifteenth century is evident from the 1486 printing of Plautus's Aululuia ("Pot of Gold"), by the Viennese humanist Conrad Celtis. It is significant that Terence's Eunuchus was also printed in this year, which saw as well the earliest of the so-called Viennese School comedies, that is, works presented on stage by Viennese students. ${ }^{60}$

In addition, the works of the German humanist Johannes Reuchlin (1455-1522) show the influence of Plautus and Terence. ${ }^{61}$ By far the most pertinent to our study is a work by the noted humanist Jakob Locher Philomusus (1471-1528), Ludicrum drama: plautino more/fictum: a Jacob locher Philomuso: de sene amato/ re: filio corrupto: \& dotata muliere: (no date, no place). ${ }^{62}$ The title alone indicates that it draws on the popular comic situation of an old woman in love with a young man. R.R. Bolgar has noted that imitations of Plautus's works, rather than translations of them, accounted for the spreading of Plautine ideas. One example can be cited for Germany-Hans Sachs's production of Menaechmi in 1548. ${ }^{63}$

\section{Hroswitha Revival}

Celtis was also responsible for the rediscovery of Hroswitha's Paphnutius. In 1494 he found in a Regensburg monastery a manuscript for which we are much indebted to him, as it included almost all of her now-known works-sacred legends, dramas, poems and dedications. ${ }^{64} \mathrm{Six}$ of Hroswitha's works were published by Celtis in Nuremberg in 1501, after having been forgotten for some six hundred years. They were illustrated by eight woodcuts attributed to Direr and his circle-including Hans von Kulmbach, Wolf Traut and others. ${ }^{65}$ The widespread and enthusiastic appreciation of her work around 1500 is demonstrated by the Greek distich penned in her honor by that ever-clever writer of inscriptions, Willibald Pirckheimer, Dirrer's humanist friend. He called her a muse and remarked that if Sappho was the tenth, then she should be the eleventh. ${ }^{66}$ 
The first literary source to have inspired a specific and identifiable representation of an Unequal Couple is Das Narrenschiff ("Ship of Fools") by Sebastian Brant (1458-1521), published in Basel by Johann Bergmann von Olpe in 1494. The work is discussed below (pp.58-59), where the chapter entitled "Marrying for the Sake of Goods" and an accompanying woodcut by Direr (fig. 32 ) will be dealt with at greater length. For now it will suffice to note the presence of a foolish young man and a shrewish, wealthy old woman. The importance of Brant's Das Narrenschiff and of Dürer's woodcut should not be underestimated. The work was reprinted more than ten times during the next twenty years, in official and pirated editions, thus spreading the idea and image of Unequal Love throughout Germany, England, the Netherlands and France.

\section{Thomas Murner}

Brant's most important and closest disciple in Germany was the Franciscan preacher and writer Thomas Murner. ${ }^{67}$ Although he drew heavily on Brant's Das Narrenschiff, Murner's lively, entertaining tone is essentially different from Brant's serious moralizing. Murner touches on the subject of Unequal Love in both Narrenbeschwörung ("Exorcism of Fools") and Die Schelmenzunft ("Guild of Rogues") published in Strasbourg and Frankfurt in 1512.68 Murner's Narrenbeschwörung not only used the Narrenschiff woodcuts but also rehashed the content of Brant's book. ${ }^{69}$ Though drawing on Brant, Murner's coverage of the subject of Unequal Love is much less extensive. Murner merely cautions, "He who takes a wife in order to gain goods and money is a fool." 70

In Die Schelmenzunft, on the other hand, Murner reprimands the men of his own generation for their attitudes about obtaining dowries (chapter 20). He charges that if an old woman were scabby, blind and disgusting she would be acceptable as long as she had money. And even if she crawled around on a crutch for twelve years, and her backside were covered with wrinkles, she would still be an empress to a young, mercenary man. ${ }^{71}$ Like his precedessor Brant, Murner concentrates on the more unusual Unequal Couple in which the woman is old.

\section{Pamphilus Gengenbach}

Pamphilus Gengenbach (fl. 1509-24) was also schooled in the language and style of Brant and was known for developing the carnival play into serious moral satire. ${ }^{72}$ In the introduction to "Der Alt Gouch" ("The Old Fool") from his Gouchmatt ("Meadow of Fools") published around 1516 "against adultery and the sin of unchastity," Gengenbach merely touches on the subject of Unequal Love: ${ }^{73}$ 
If you had a lot of money in your purse

That you have certainly already eaten into

Then perhaps you would consider my money bag

And also allow me to be your beloved man. ${ }^{74}$

And in his "Lied von der Narrenkappe" ("Song of the Fool's Cap") from the same work, an old man grabs the backside of a young woman who then demands his full purse. She adds that if the purse belonged to her she would see him no longer. Age, she continues, provides for women so that old men can no longer play skittles (that is, indulge in sexual activity). For that reason, these men are presented with fools' caps. ${ }^{75}$

\section{Desiderius Erasmus}

The discussion of Unequal Lovers by the humanist Desiderius Erasmus (1469?-1536) in his Praise of Folly first printed in 1511, referred to below (p.61), remains the most detailed description of both sets of aged lovers consorting with younger partners. Erasmus, however, speaks of mercenary love only in the case of the old woman who hires a young man for large sums of money. He says that the old man, on the other hand, can very well take a young woman as his wife according to common practice.

In the 1523 edition of Erasmus's Colloquies, five stories deal with various aspects of love and marriage. ${ }^{76}$ In "Marriage," Xanthippe discusses her terrible husband with her old friend Eulalia, who suggests love and understanding as a means of increasing marital harmony. In the course of the conversation Eulalia makes reference to an Unequal Couple:

Eulalia: I know you're acquainted with Gilbert the Dutchman.

Xanthippe: I know him.

Eulalia: As you're aware, when he was in the prime of life he married a woman already in her declining years.

Xanthippe: Perhaps he married the dowry, not the wife. ${ }^{77}$

In another Colloquy, "A Marriage in Name Only, or, The Unequal Match," first printed in 1529 in Basel, a syphilitic is married to a beautiful young woman. One of the narrators remarks,

I've sometimes heard theologians discussing marriage between unequals. Surely this could be called with perfect justice a marriage of unequals-as though you set a jewel in lead. ${ }^{78}$

The implication, of course, is that marriage between individuals of unequal ages or appearances was a well-known matter for theological debate. Earlier in the work Erasmus assures the reader that many British and Italian girls marry septuagenarians, and that ancient authority acknowledges the 
appropriateness of these matches, at least from the groom's side. ${ }^{79}$ Unfortunately, Erasmus never discloses the identity of the ancient authority.

Also closely associated with Erasmus are the rederijker or rhetoricians' poems and prose novels, written in the early sixteenth century in the Netherlands, and discussed later in this work (p.69).

\section{Hans Wandereisen}

One of the few Unequal Couples executed as a single-leaf woodcut complete with text was printed at Bamberg in 1519, among the earliest works of the astronomer-printer Georg Erlinger (d. 1542). ${ }^{80}$ Designed by Hans Wandereisen (d. 1548?), ${ }^{81}$ the woodcut (fig. 3) bears the caption, "A young man's adventure/Is an old man's atrocity." 82 It depicts a trim young

3. Hans Wandereisen, Old Man and Young Wife, 1519, woodcut

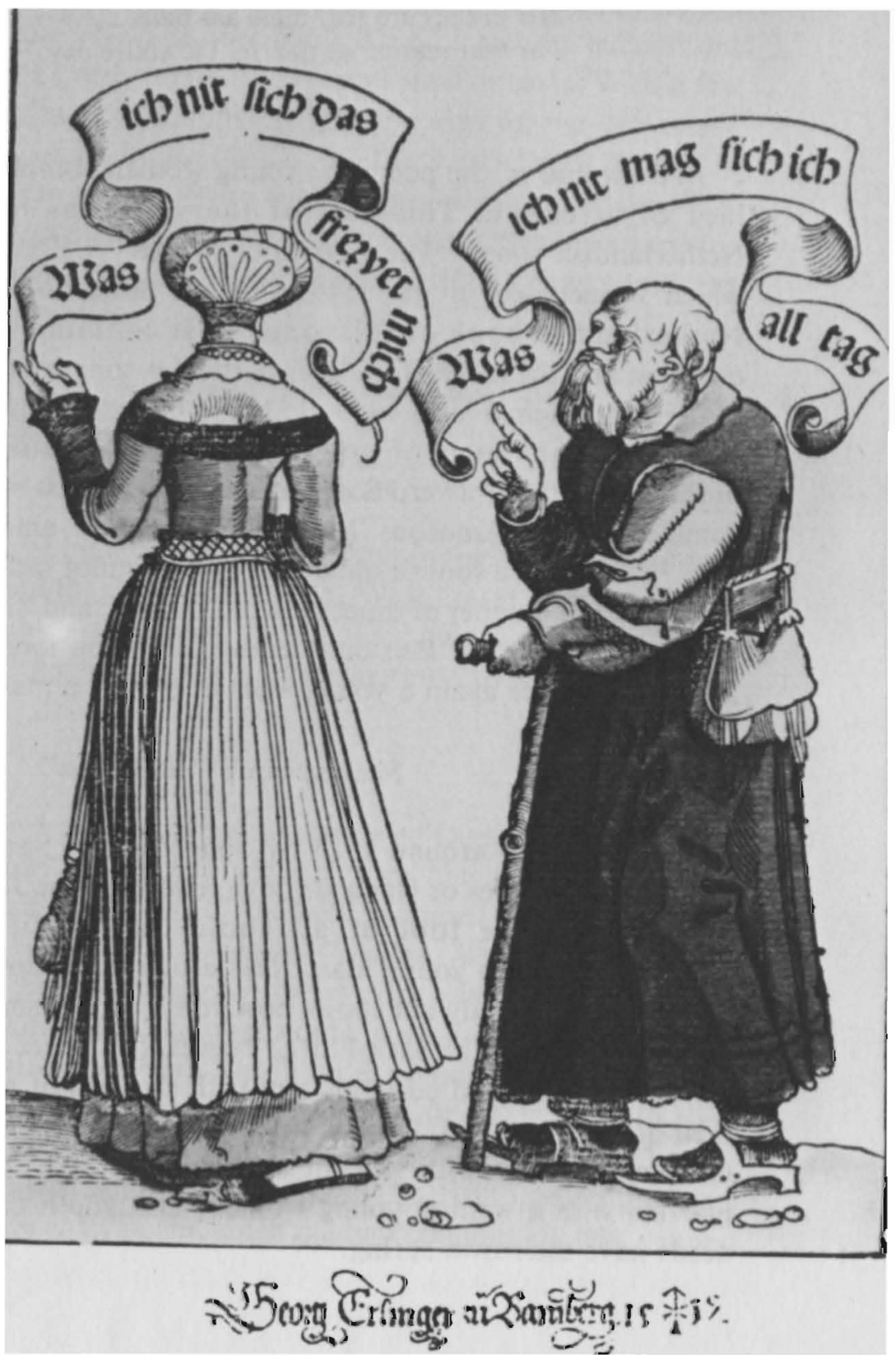


woman who, in a banderole above, says, "What I don't see [young men], I like." Her husband responds with, "What I don't like [my wife], I see every day." The text, which ran beneath the print and is missing in the illustration here, further explains, first in the husband's words and then in the wife's, their less than joyous union. The man bemoans his age and its unpleasant effects on lovemaking, and his wife's desire for young men. She in turn is unhappy with her mate, whom, she admits, she married for his wealth. She longs for a young man.

The most poignant declaration of the couple's differences is made by the old man:

My love is young, and I am old, She is very hot, and I am cold, Her hair is yellow, and mine is gray Her cheeks are red, mine are blue, ... .

For that reason we quarrel the entire day, 83

At the end of the poem the young woman complains of the old man's lack of affection. This part of the work has been compared to a Netherlandish song, "The Arrival of Winter" ("Den Winter comt aen"), which is included in the 1544 Antwerp Songbook (no. 26), the oldest Netherlandish book of folksongs. ${ }^{84}$ It contains works from popular tradition and the rederijkers. This particular song is believed to be based on a German original printed in $1536 .{ }^{85}$ Included among numerous other Netherlandish songs of young women complaining about their old husbands, in the Antwerp Songbook, are two which may be singled out for comment: "An Amorous Little Song" ("Een amoreus liedeken"; no. 193), ${ }^{86}$ in which a foolish old doctor, who cannot satisfy his young patient, syringes her a number of times between the legs; and "An Old Man Spoke to a Young Woman" ("Een oude man sprack een ionck meysken an"; no. 263), where once again a young woman prefers a man her own age.

\section{Shakespeare's "Jestbooks"}

First printed around 1525 by John Rastell, Shakespeare's Jestbooks include three stories of Unequal Love related by the Jacke of Dover, who is in search of the fool of all fools. In the first, "The Foole of Buckingham," 87 a young man tricks a rich old widow into marrying him. The tale ends happily but shows how youth can outsmart old age, as it does also in another, "The Sack-Full of Newes." 88 There a young woman fools her old husband and cuckolds him with the help of a young man living in their house. Lastly, in "The Foole of Bedford" 89 the fool proclaims his own unequal marriage with, "I am an old man, and not the first that have married with a wanton young woman, and youth coupled with age must needs have their own spring." 90 


\section{Netherlandish Farce}

Unequal Love was also included in another type of Netherlandish literature, the farce. In Cornelis Everaert's Van Stout ende Onbescaemt ("Of the Naughty and Unashamed") of 1527, another lusty wife complains of her old husband, who is no longer capable of marital joys. With this in mind she arranges to meet the sexton, though as it happens, their meeting will be interrupted. ${ }^{91}$

\section{Tyrolean Carnival Play}

A most unusual work dealing with this theme is an old Tyrolean carnival play of 1529 entitled Eine Ehescheidung ("A Divorce"). ${ }^{92}$ The rather lengthy piece centers around an old husband and a younger wife who wish to be divorced on the grounds of sexual incompatibility. In not always the subtlest of terms, the wife describes her husband's meager endowment and he comments on her overly large measure and small breasts. With a few obscenities to the side, a midwife investigates the size of the old man's genitals and discovers, much to her dismay, that he has relieved himself in his gown. Disgusted, she cries, "Puh, du hast ins Hemd geschissen!" A discussion ensues among men of various regions, and a Swabian explains that in the south German regions of Bavaria and Swabia a man should be nine thumbs in length:

\footnotetext{
He should certainly reach through the hair, Standing a while and afterwards hanging. Nine thumbs in length he should afterwards be, That is correct in Bavaria and Swabia. ${ }^{93}$
}

Master Arnold introduces himself and explains that in the Netherlands both length and size are prized for good lovemaking. With this in mind the judge hands down his decision, stating that the couple should be divorced, and should seek compatible partners, ones more their respective sizes.

\section{Hans Sachs}

The last literary work documenting the theme of Unequal Love before 1535 is the poem Zweierlei Ungleiche Ehen ("Two Unequal Marriages") written in 1533 by Hans Sachs (1494-1576). Like Erasmus's Praise of Folly, Sachs's poem includes both sets of Unequal Couples. A young mercenary man woos a rich old woman with dry, wrinkled skin, and they are married despite her suspicions concerning his sweet words. A young woman similarly flatters an old man who is in love with her, in order to gain possession of his money. The old man dons a fool's cap, which adds one more fool to the many old people Sachs tells us have already joined the fools' ranks. ${ }^{94}$

A woodcut of somewhat later date (1570) is considered to reflect the lost original accompanying Sachs's poem, since the two columns of text below 
4. Netherlandish, after a design by Virgil Solis, Unequal Couple: Old Woman with Moneybag and Young Man, ca. 1570, woodcut

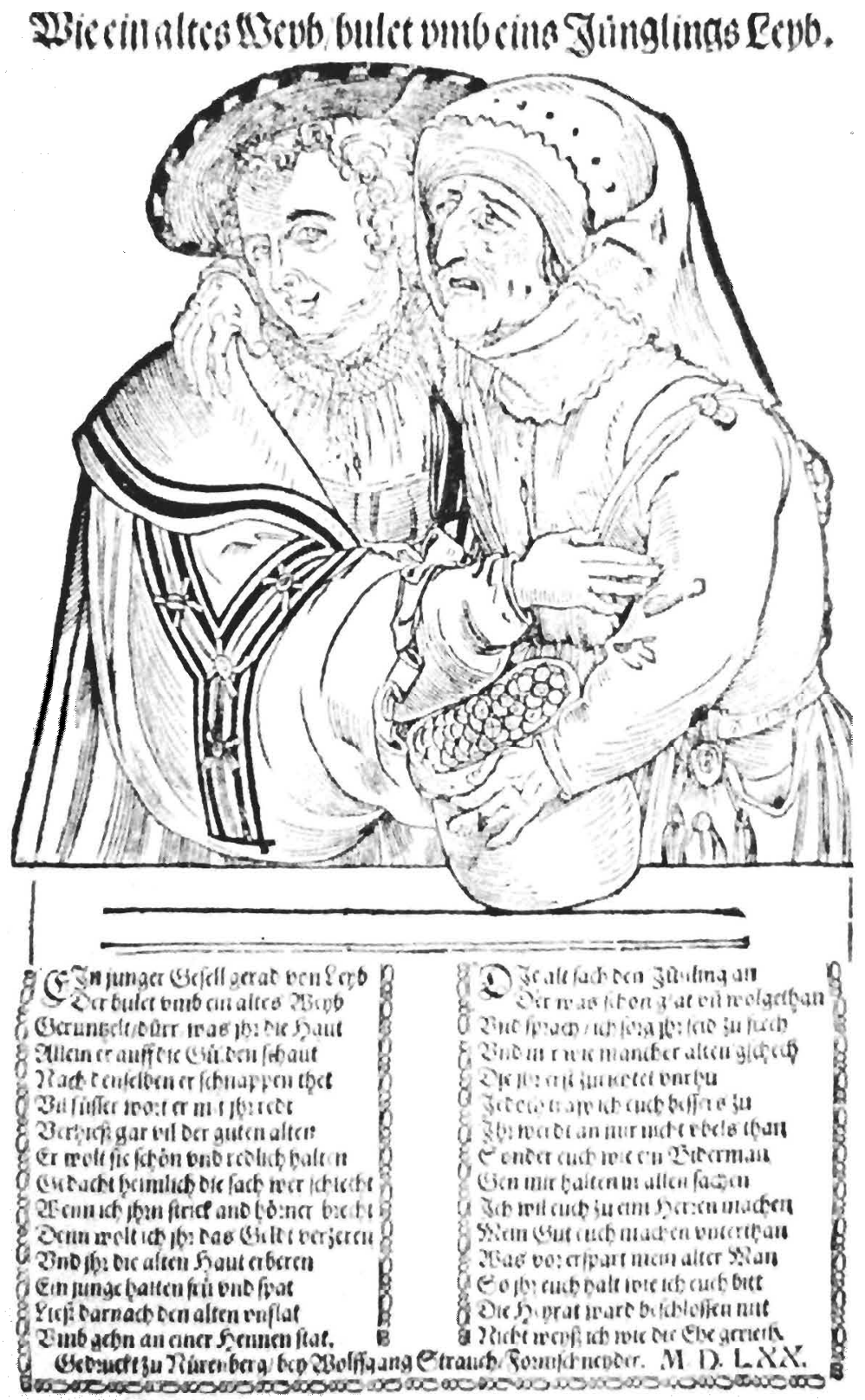

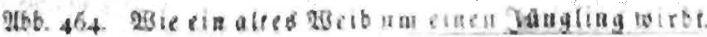

the woodcut (fig. 4) are identical with the last thirty lines of Sachs's work. The Nuremberg graphic artist Virgil Solis (1514-62) is credited with the design of the woodcut. ${ }^{95}$ The first thirty lines of Sachs's poem have come down to us beneath an anonymous Netherlandish woodcut (fig. 5), entitled Van die valsche ontrouwe Liefte ("Of False, Untrue Love"). The illustration, which in form undoubtedly goes back to Urs Graf's woodcut (fig. 6) of around 1511, was printed at Campen by Pieter Warnersz. Woenende, probably around the middle of the century. ${ }^{96}$ 
2. Com die balletie ontronbe ziefte.

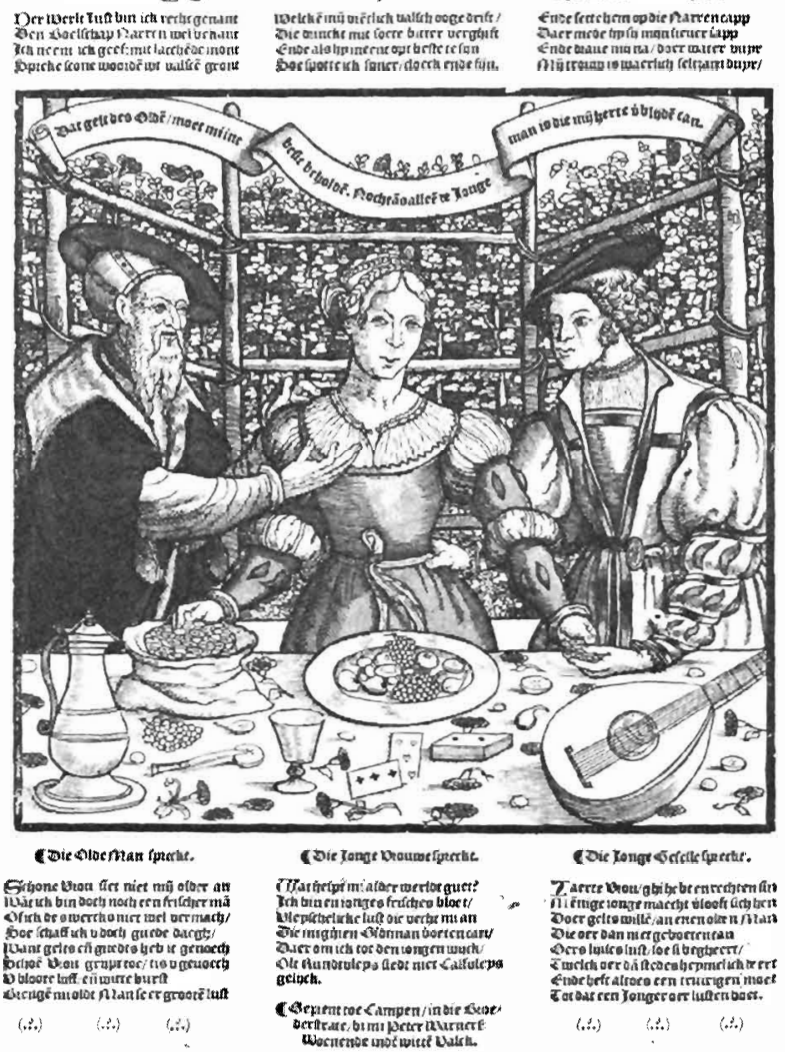

5. Netherlandish, Iove Triangle with Symbols of Pleasure and Transience: "Van die valsche ontrouwe liefte," ca. 1550, woodcul
6. Urs Graf, Love Triangle with Symbols of Pleasure and Transience, ca. 1511 , woodcut

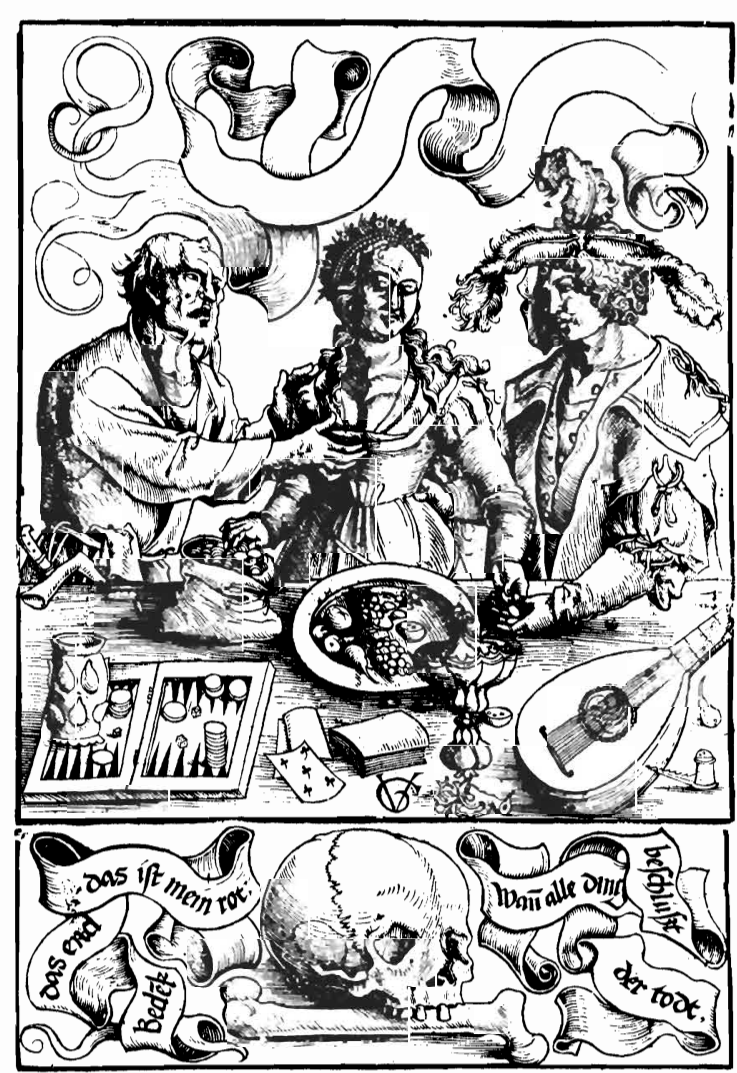




\section{Conclusion}

Carnival plays, humorous stories, and tales found in manuscripts, as well as the dramas of the Hroswitha and Plautus revivals, among others, served as the literary inspiration for representations of Unequal Lovers in northern Europe from about 1475 to 1535 . In most cases both the humor of the unequal relationship and the satirical approach to it are readily apparent. Beyond the satirical undertones, there seems to have been little, if any, attempt at moralizing. The old partners, who are mostly male, are portrayed as foolish for having chosen young partners and for believing that they would remain faithful. The young women, on the other hand, are described as conniving, mercenary, and deceitful. Ultimately the women are viewed as more powerful in Love, although theirs is a power that is considered less than positive, certainly not commendable. By the same token, the women come in for more criticism than their male counterparts-young women are deceitful and cunning, old women disgusting. Men, either old or young, are merely foolish. In any case, such a misogynous literary bias should come as no great surprise.

The interest in Unequal Lovers in literature crossed class boundaries. That the fruit tree tale was included in two manuscripts indicates that the wealthy manuscript audience was interested in literature oriented toward the erotic and the satirical. The presence of St. Peter and the Lord therein may have functioned as the justification for these works. The Unequal Lovers theme was also included in the more raucous and obscene carnival play, which suggests a different audience, one that included a less monied and educated and more down-to-earth class. Carnival plays need not, of course, have been as outspoken as the works discussed above. The inclusion of another Power of Women theme, that of Aristotle and Phyllis, in a carnival play that has recently been linked to a German court, ${ }^{97}$ suggests that carnival plays were viewed by high and low alike, and thus by the entire range of late medieval society.

Certainly the ideas underlying the visual representation of Unequal Lovers were common enough, and need not have been direct pictorial responses to specific literary sources. In fact, we have seen that only Brant, Erasmus, and Sachs penned works that inspired specific works of art. It seems unlikely that different works of literature would have been solely responsible for three basic types of composition in painting and graphics, as broken down in the Handlist below (p 137). More likely, the common ideas found in these literary works were part of the general spirit of the time that satirized the pairing of old and young while delighting in the folly and titillation involved. The large number of representations of Unequal Couples and Love Triangles, and the variety of literary works that included the theme indicate that it was indeed a popular topos in northern Europe around 1500. 


\section{Chapter 3}

\section{Artistic Predecessors \\ Unequal Lovers before ca. 1470}

Old men and young women are rarely found together in northern works of art, until they appear as the Unequal Couple in the last quarter of the fifteenth century. It is curious, however, that the first representation of an isolated old man and a young woman is depicted in an English psalter of ca. 1310-25 (fig. 7). In the Gorleston Psalter illumination, which is, of course, part of a larger work, a bearded old cleric empties his money sack while a young woman with long, unbound hair acknowledges his action by raising her left hand. ${ }^{93}$ The old man's beard and stooped posture indicate that he is much older than his partner, whose youth is suggested by her hairstyle. ${ }^{99}$ The only visible connection between the two is the gesture and possibly a glance. Although this psalter decoration appears to be serious in tone, the mere depiction of such a subject may have been intended as satiric.

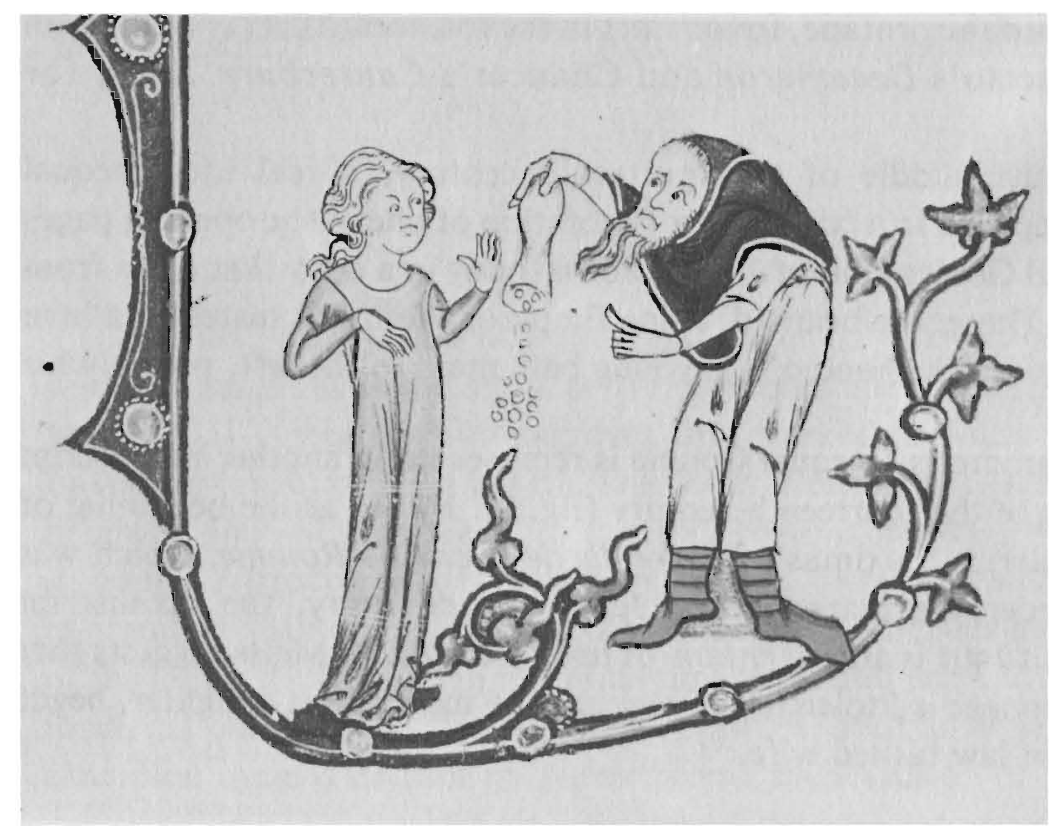

7. English, Old Cleric Dumping Coins Before a Young Woman, illumination from the Gurleston Psalter, ca. 1310-25, London, British Library, Add MS. 49622 


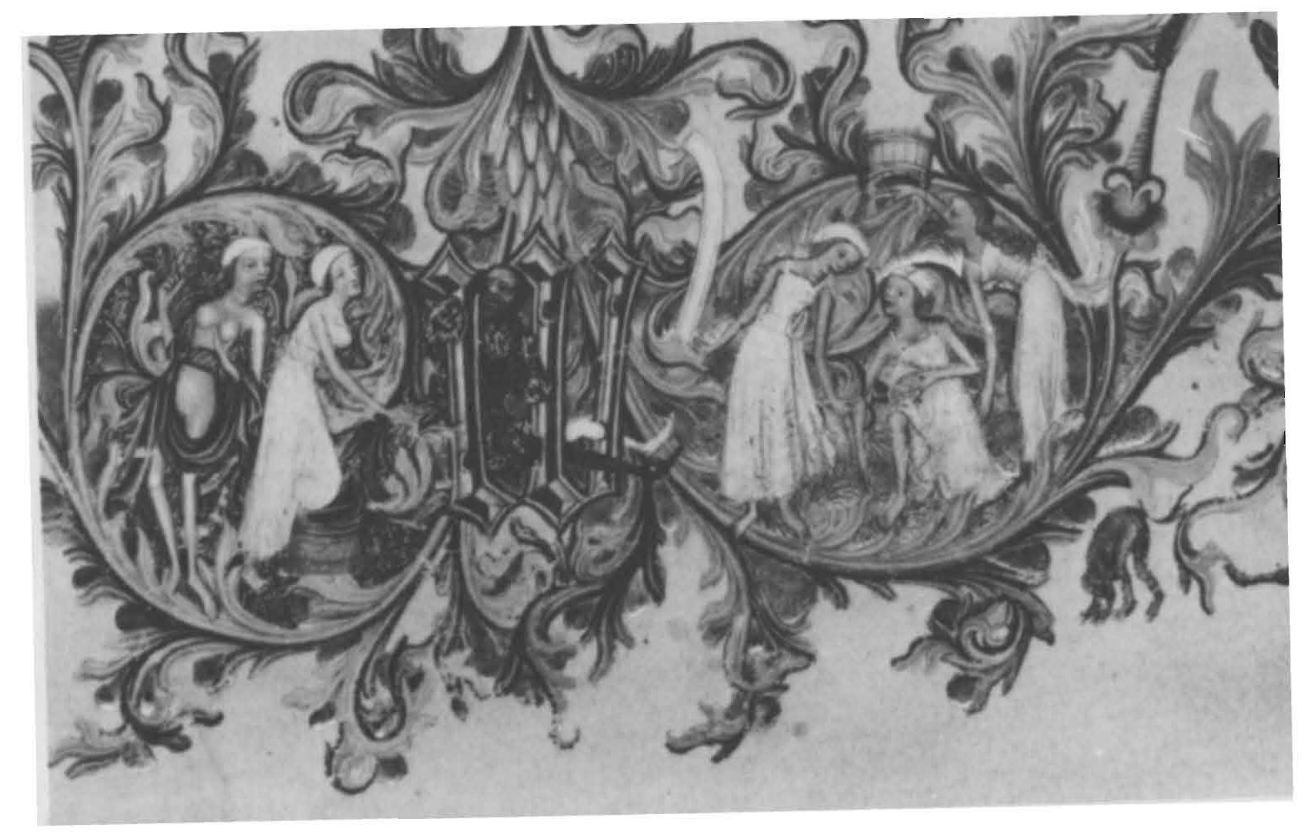

8. Anonymous Bohemian, Emperor Wenzel Seated in a Love Knot with a Bath Maid, illumination from the Imperial Golden Bull, ca. 1390, Vienna, Oesterreichische Nationalbibliothek, Cod. $338 \mathrm{f} \mathrm{Ir}$

Might such a representation have been the visual equivalent of exempla, those sketches from everyday life or classical mythology that were used by the mendicant orders in the fourteenth century to spice up their sermons? In other words, depictions of subjects like this one may have been intended to bring renewed interest to religious books. However, the inclusion of such titillating subjects may simply reflect an increasing literary and artistic tendency toward the profane, found later in the fourteenth century in ivories and in Boccaccio's Decameron and Chaucer's Canterbury Tales, for example.

Around the middle of the fourteenth century, a real life Unequal Couple was depicted in a bas-de-page decoration of one of the opening pages of the Imperial Golden Bull of 1356, known today in a copy that dates from around 1390. There, the bearded, aging Emperor Wenzel is seated in a love knot, reaching for the hand of the young bath maid to the left, possibly his wife (fig. 8). ${ }^{100}$

A more amorous Unequal Couple is represented in another manuscript from the turn of the fourteenth century (fig. 9). Placed at the beginning of book 9 of Valerius Maximus's Fais et dis de la cité de Romme, which was translated under the patronage of Jean, duc de Berry, the manuscript illumination of 1401 is an exemplum of luxury or luxure. Meiss suggests that the royal personage is Ptolemaeus Physcon who married his daughter, begot by his sister-in-law turned wife. ${ }^{101}$ 


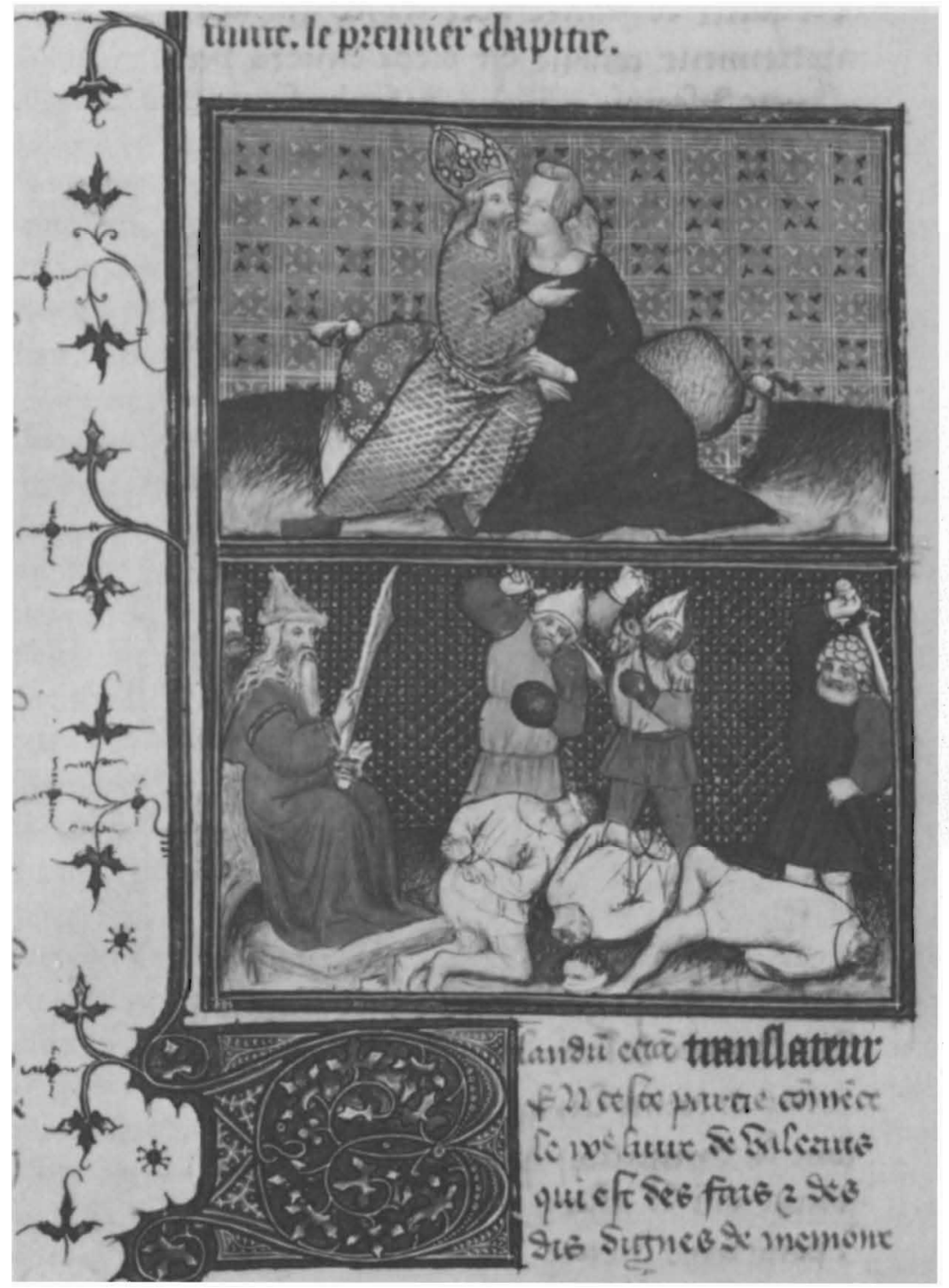

9. Franco-Flemish, Old Prince Fondling a Young Woman (Ptolemaeus Physcon with his Daughter?), illumination from Valerius Maximus, Fais et dis de la cité de Romme, 1401, Paris, Bibl. nat. fr. 282 , fol. 345

Related to the Gorleston illumination in its possibly anticlerical and sexual intimations is the letter $b$ (fig. 10) from the Fantastic Alphabet of Master E.S., the goldsmith-engraver who worked in South Germany near Lake Constance around 1450-67. This letter is one of two in E.S.'s alphabet of about 1466-67 that seem to involve relations between the sexes. ${ }^{102} \mathrm{~A}$ standing, aristocratic lady, probably young, forms the stem of a Gothic miniscule $b$ while an older man, possibly a clerk, comprises most of the bowl of the letter. ${ }^{103}$ Dressed in rather elegant gown and robe, the lady does not touch her companion. Their gazes do not meet and, as in the two previous examples, there is no money. Nevertheless, the inclusion of birds and dogs 
10. Master E.S., Letter $b$, from the Fantastic Alphabet, ca. 1466-67, engraving

11. Master E.S., Letter $m$, from the Fantastic Alphabet, ca. 1466-67, engraving
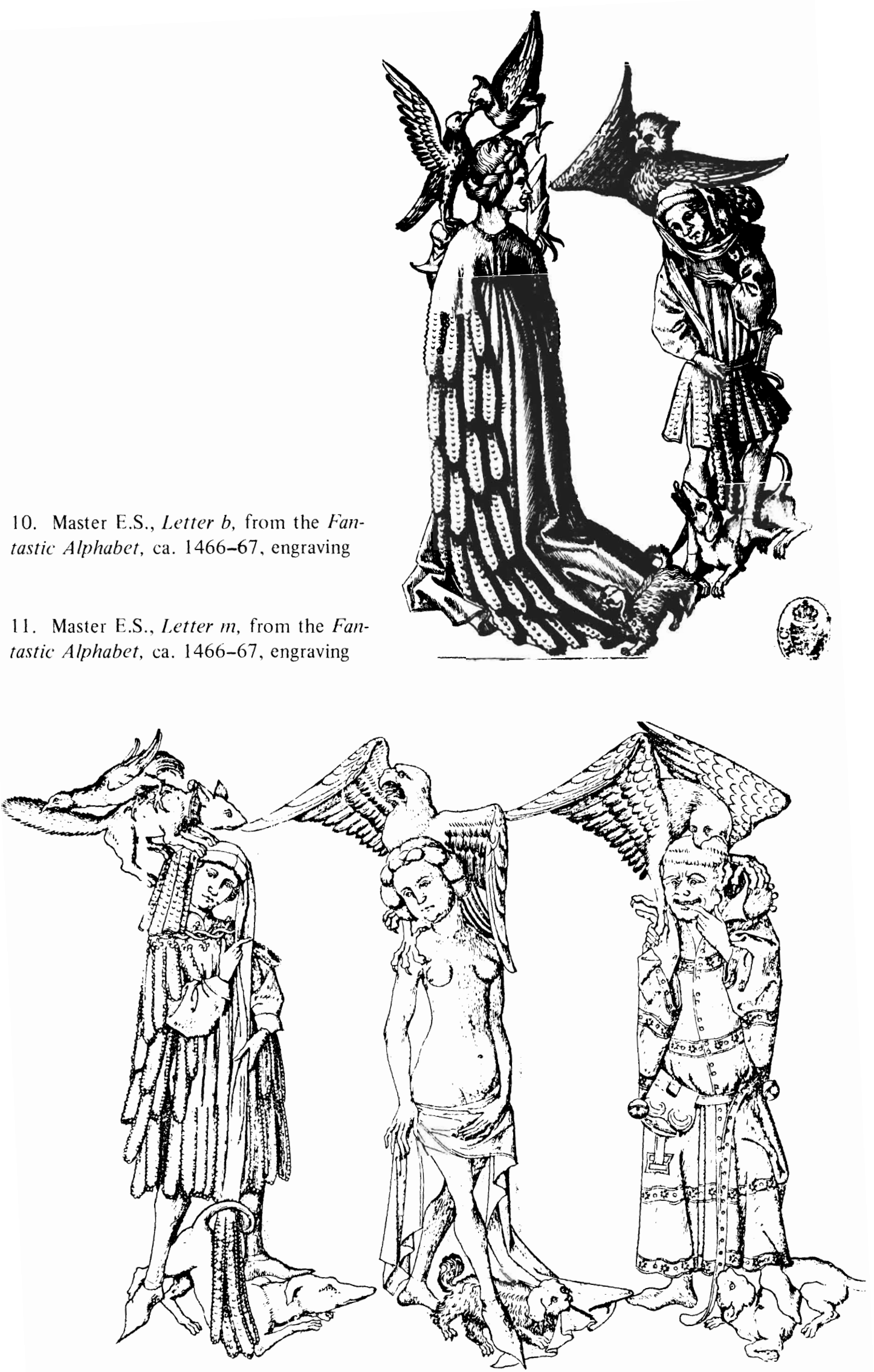
filling the spaces between the figures, both in this letter and in the letter $m$ (fig. 11) points to the satirical tone of the engraving: dogs and birds in such contexts were considered to denote lust. ${ }^{104}$ The claw(?) the woman holds may have been associated with falconing and therefore with the hunt, which was often used, in literature and art of the time, as an allegory of love. It is tempting to suggest that the woman's larger size symbolized the power that she, and women in general, were believed to hold over men in love affairs, though Master E.S. may merely have liked the visual aspect of this size distribution for this letter.

The satirical intent is heightened and becomes more explicitly related to Unequal Love in the same master's initial $m$. There, a nude young woman covered only by a cloth held over her genitals, stands between a gallant and a caricatural, lustful old man or monk in fool's costume. Since the woman seems to be the object of both men's attentions, the composition may have been the type of precursor that served to inspire the later Love Triangle, which expanded the Unequal Couple composition in the second decade of the sixteenth century. The lascivious overtones suggested by the men's gestures, as well as by the inclusion of dogs and birds, suggest that this composition may have been intended as the visualization of the initial letter of Minne, physical or impure love, a word banned from polite usage within the next fifty years because of its obscene connotations. ${ }^{105}$ Similarly, E.S.'s initial $b$ may have stood for Buhlerei or lechery. ${ }^{106}$ The bird that is pecking away at the fox's tail in the initial $m$ may have been intended, as Louis Maeterlinck quite unconvincingly suggested, to symbolize the oppression of wisdom and faithfulness by feminine foolishness. ${ }^{107}$ The placement of these animals over the young man more appropriately implies his loss of wisdom because of his sexual attraction for the young woman. Thus woman's sexual power and man's corresponding weakness for her are satirically represented by E.S. in these two letters, both portraying old men with young partners.

At least one other example of old men exhibiting their lascivious interest in young women has come down to us from the second half of the fifteenth century. In a Franco-Flemish minature (fig. 12) depicting a bathhouse scene, ${ }^{108}$ a number of men, probably old, join in a repast of bread and something from a bowl, possibly soup or mush. ${ }^{109}$ They wear nothing but head wraps and they are seated in wooden tubs opposite pretty young women who also wear nothing but necklaces and headdresses. While these old men delight in this activity, another old man directly behind them places his hand on his companion's genitals as the two step into a bed chamber, making the object of their association clear to the viewer.

The lighthearted tone of this miniature is shared by an engraving of the same theme, which indicates the folly of such activities. In the satirical Bathhouse (fig. 13) engraved by the Master of the Banderoles, who was active around 1450-75, possibly in the north Netherlands, a fool appears with his genitals exposed by a woman who pulls his gown aside as she steps outside the bath enclosure. Behind her another woman offers her own 


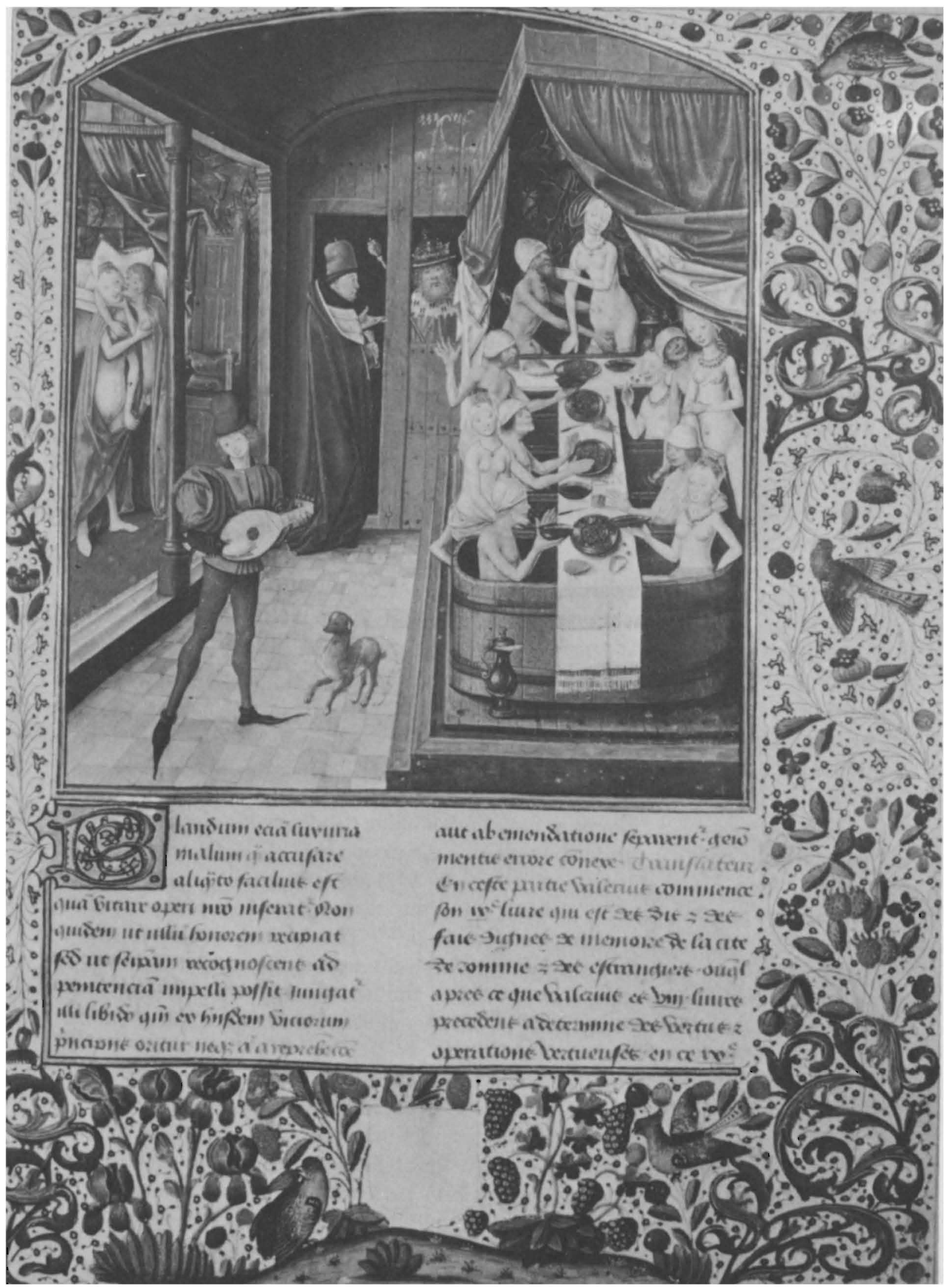

12. Anonymous Burgundian(?), Repast in a Bathhouse, 1450-1500 


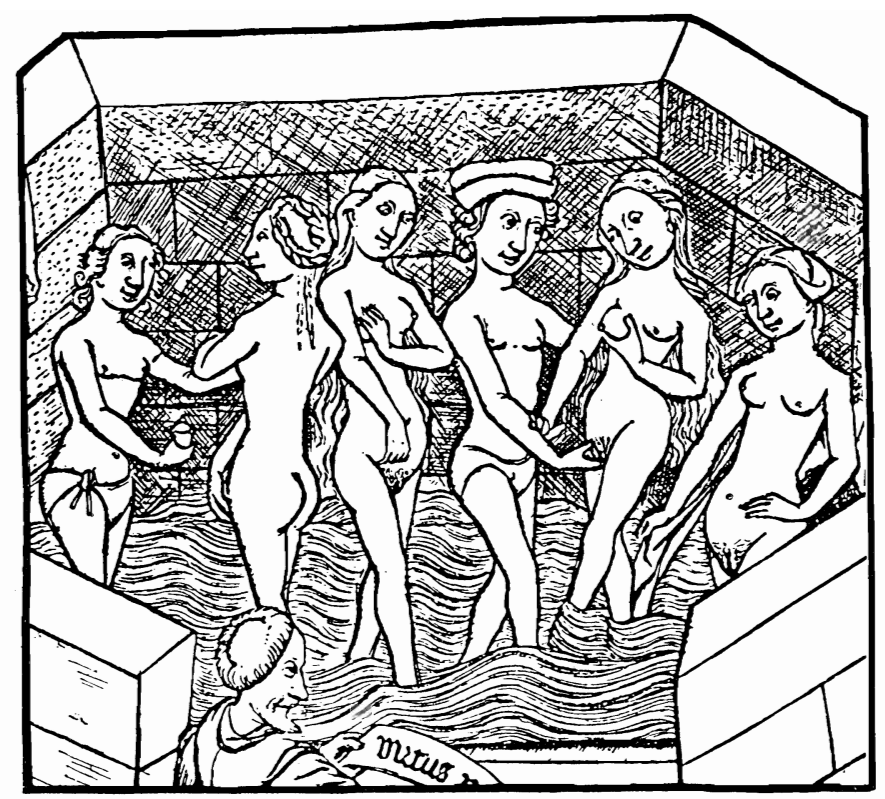

13. Master of the Banderoles, Bathhouse as Brothel, ca. 1450-75, engraving

breast. ${ }^{110}$ The exposure of the man's penis, the source of his foolish behavior, is in keeping with the interpretation of such "love" scenes as satiric. The inclusion of the adjoining bedchamber supports the general belief that bathhouses frequently doubled as houses of prostitution.

Whether as an independent work of art or as part of a larger representation, the old man with a young lover was most likely viewed, in the second half of the fifteenth century, as an old fool fallen under the power of woman's physical charms. This interpretation can easily be applied to the Housebook Master's Unequal Couples, especially to his Old Man and Young Woman (fig. 14) where the young woman appears to look slyly over

14. Housebook Master, Old Man and Young Woman, ca, 1472-75, drypoint

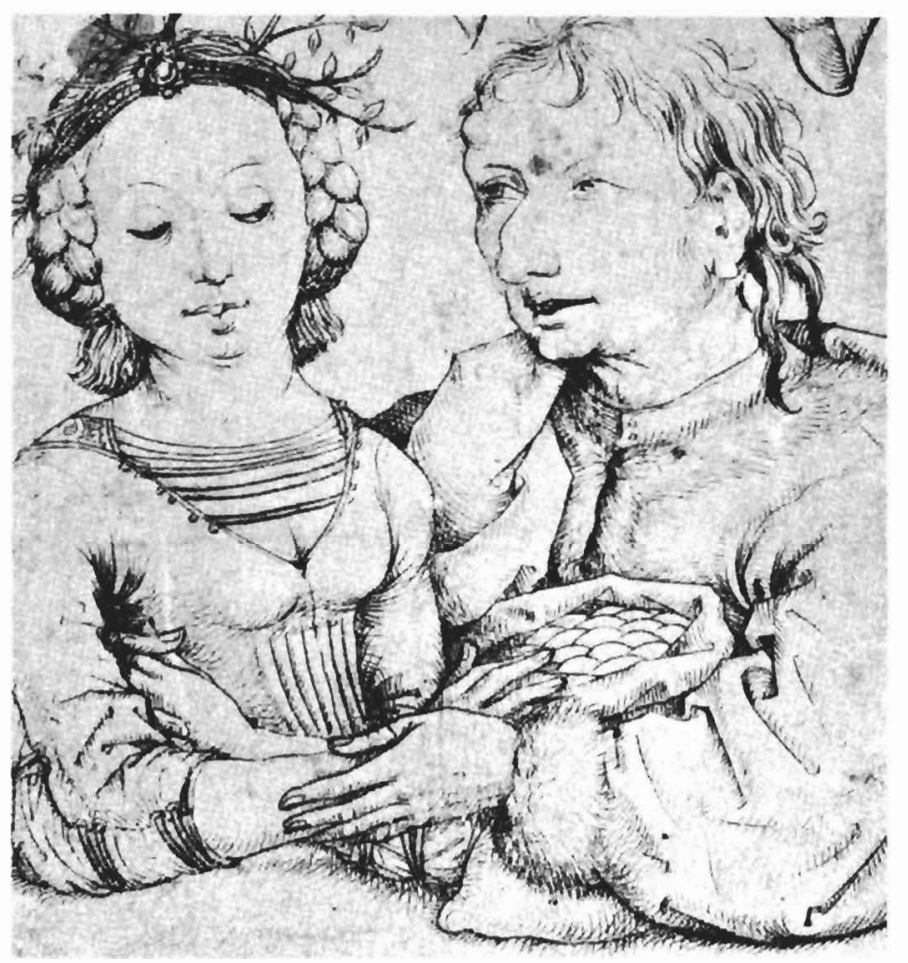


at her old partner, whose money she accepts as she allows his hand to inch toward her breast. Thus the old man is a fool and the woman a wily deceiver.

Form

Embracing couples, depicted in a manner both satirical and didactic, are typical of Unequal Lovers and related fifteenth-century prints. Embracing lovers, for example, can be found in the Master of the Love Gardens' Small Garden of Love engraving (fig. 15) of about 1445-50, ${ }^{11}$ in which a man, seated on the ground in the second tent from the right, embraces his partner while slipping his free hand under the bodice of her dress. The men in this engraving wearing turbanlike head coverings are certainly exotic and may even have been intended as old men in contrast to the obviously younger men with long, flowing hair. A similar though more overtly erotic gesture appears around 1450 in an early engraving by Master E.S., Amorous Couple on a Grassy Bench. There a young gallant gingerly fondles his young companion's breast as she gently and halfheartedly pushes him away. Included are a tiny lapdog and a falcon that hunted small game, which may refer to luxuria and to the hunt as an allegory of love. ${ }^{112}$ It is perhaps not coincidental that the placement of the young man's sword is sexually suggestive and that the center of the engraving is located at the woman's lap.

A vigorously amorous embrace, like that in many Unequal Couples, is seen in a woodcut from Strasbourg that dates around 1460. "Du solt nit unkeusch sein" (fig. 16), announces the seventh commandment, which warns against the unchastity depicted beneath it. ${ }^{113}$ Placed within a walled garden, two young lovers seated on the ground have been brought together with the assistance of the demon above their heads. The warning against improper sexual involvement is implied by the embrace and the demon and spelled out by the inscription.

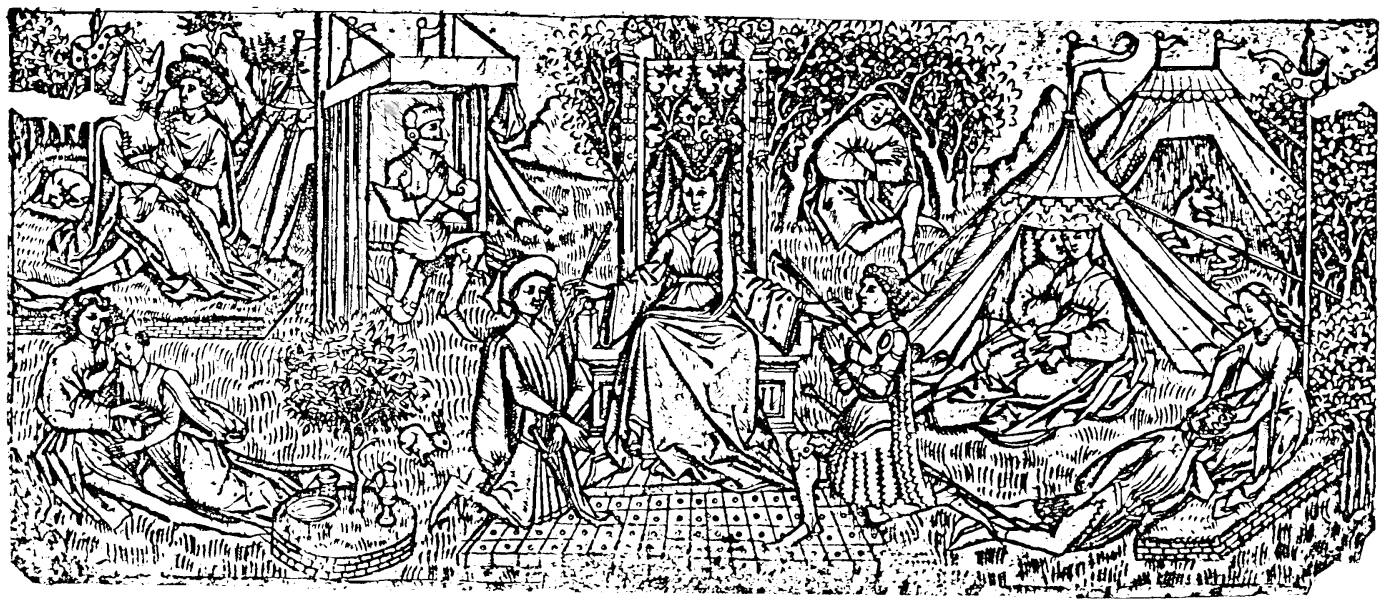

15. Master of the Love Gardens, Small Garden of Love, ca. 1445-50, engraving 


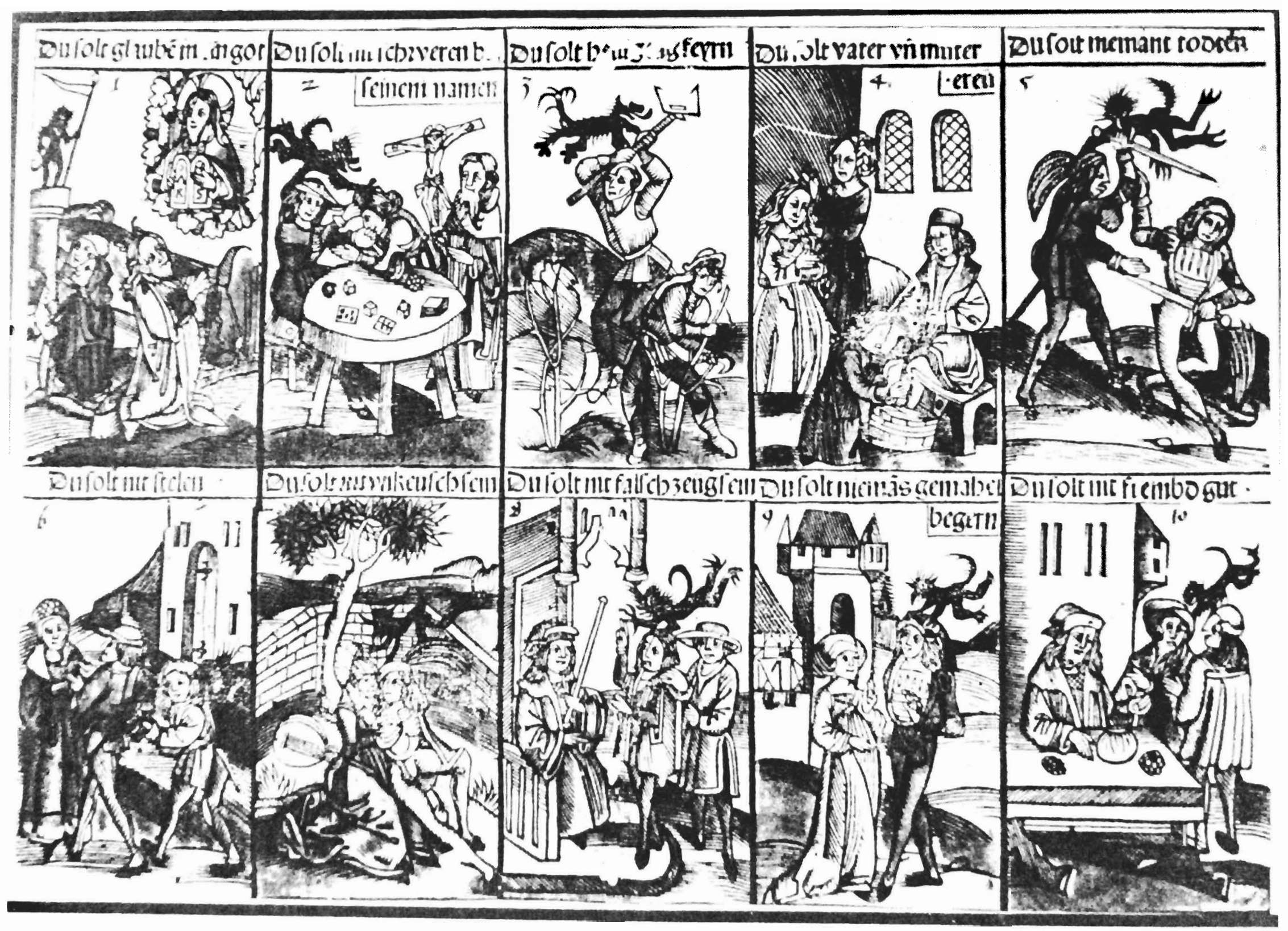

16. Anonymous Strasbourg, Thou Shalt Not be Unchaste, Seventh Commandment from the Ten Commandments, ca. 1460, woodcut 


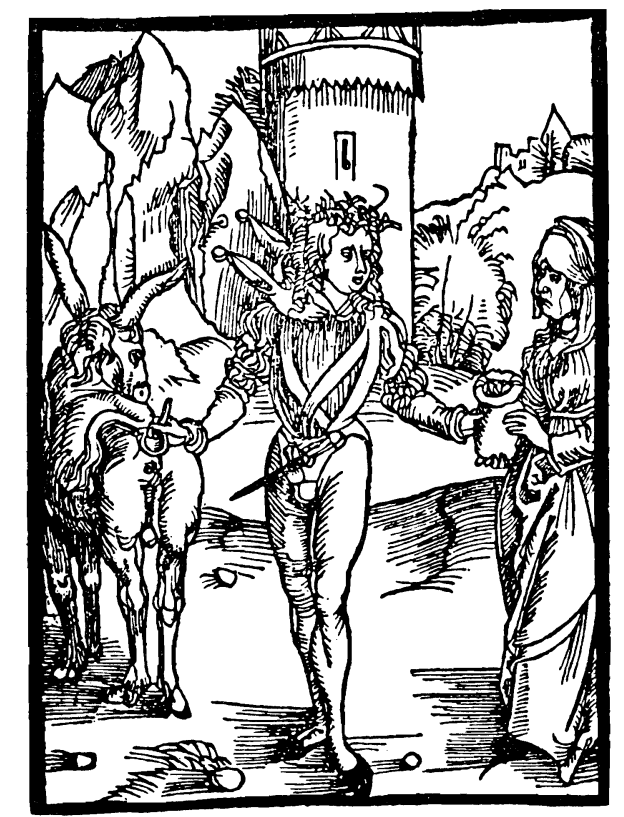

17. Albrecht Dürer, Old Wife and Young Fool, from Sebastian Brant's Narrenschiff, 1494, woodcut

The ninth scene in the Strasbourg woodcut bears a compositional resemblance to another by Dürer in Brant's Das Narrenschiff (fig. 17). This scene, illustrating the ninth commandment and captioned "Du solt niemās gemahel begern"' ("You shall not covet your neighbor's wife') portrays a young man who is similar in type to Dürer's "Young Fool," and the tower in the background of both prints may have had an iconographic significance that has been lost to us today.

Illustrations of the Ten Commandments in woodcut continue to be printed during the last quarter of the century, when an embracing couple brought together by a demon and also seated on the ground in an enclosed garden (fig. 18) was included in the Büchlein das du heisset der Sele trost

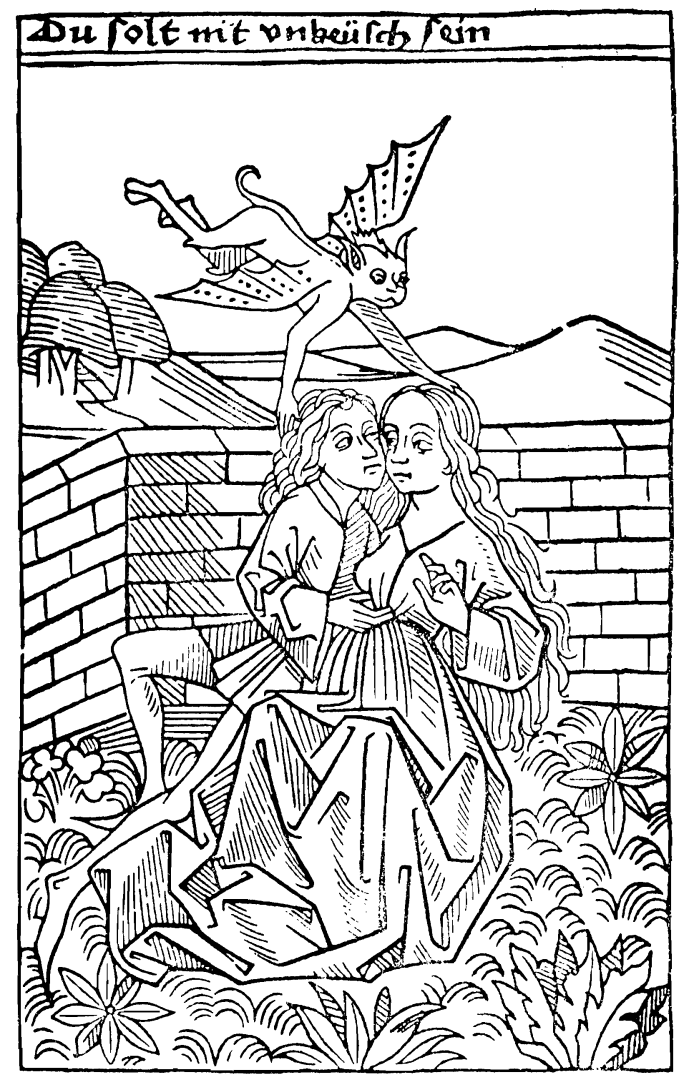

18. Augsburg(?), Embracing Couple with Demon, from Büchlein das du heisset der Sele trost, 1478, woodcut

19. Lucas Cranach, Ten Commandments, 1516, panel, Wittenberg, Lutherhalle 
("Book of the Soul's Consolation"), published in Augsburg (Anton Sorg) in 1478. ${ }^{114}$ The popularity of the Commandments as a theme for artists seems to have continued, and in 1516 Lucas Cranach arranged his ten painted rectangular scenes (fig. 19) five over five as in the earlier Strasbourg woodcut. ${ }^{115}$ The unchaste lovers of the seventh commandment have been placed within a much lusher landscape setting, and the older man's offer of a drink seems to have been a convention for sexual invitation in northern art from the fifteenth through the seventeenth centuries. The ninth commandment, the admonition against adultery, on the other hand, is placed within an interior setting and shows an old man asleep in bed while his wife consorts with a younger man standing to the right of their bed. A winged demon with pendulous breasts encourages these evil activities, as in Niklaus Manuel's almost contemporary drawing, Old Woman, Young Man and a Demon (fig. 37). ${ }^{116}$

The Unequal Couple seems to have taken a form similar to that of the embracing lovers found in love gardens or other scenes of lascivious activity, including scenes from the Ten Commandments in art around 1500. Whether the Unequal Couple form was consciously derived from these representations is debatable, since the themes are so related that the association would have been obvious to a viewer of the time. The tone of such woodcut representations as the Ten Commandments, however, should be clearly differentiated from that of Unequal Couples in engravings, since the woodcut tradition and its audience in the fifteenth century seem to have been more conservative and traditional and open to a greater degree of moralizing. Thus we find far fewer Unequal Couples in woodcuts than in engravings. Nevertheless, the embracing lovers, whether in woodcuts or engravings, had a marked association of unchastity. In the new context of the Unequal Couple, unchastity became much more lighthearted. The didactic and moralizing tone gave way to the satirical, and even to frank interest in the lascivious and the titillating.

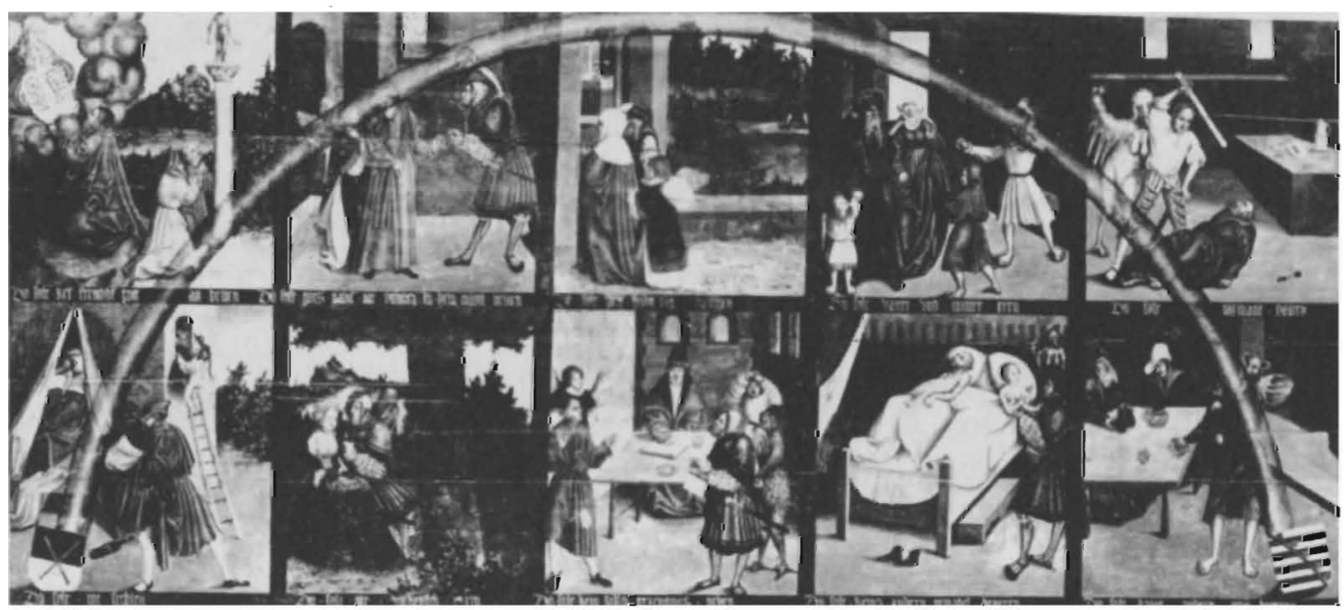




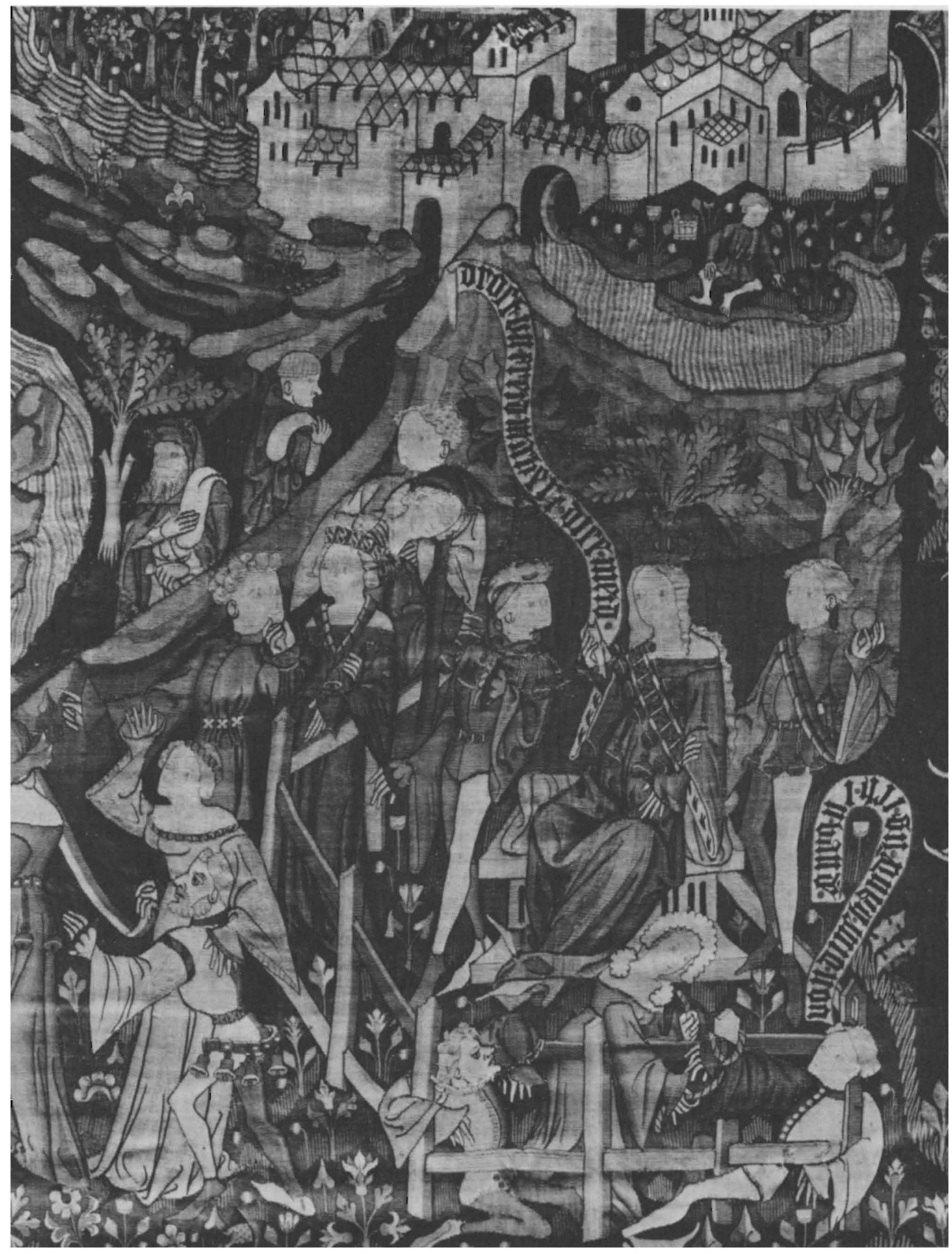

20. Rhenish. Dame Venus Presiding Over the Court of Love with Men Tied to Its Fence, ca. 1400-1425, tapestry, Nuremberg, Germanisches Nationalmuseum 


\title{
Chapter 4
}

\section{Symbolic and Iconographic Elements}

\author{
Dame Venus
}

Dame Venus may have been the most influential figure in fifteenthcentury northern literature and art, one who affected the contents of many a page, print and tapestry. The influence of this beautiful woman extended not only over the ostensibly pure courtly lovers, romping in love gardens, but also to couples engaged in more intimate embraces.

This lady's influence was nothing new, for much of the absurd behavior described in texts since antiquity characterizes lovers as blathering dolts, who, whether it is stated or not, have Dame Venus to thank for their improprieties. She is included in some early fifteenth-century tapestries (fig . 20) as the queen of love, in command of both male and female lovers. As that late Gothic century progressed-especially after 1450-Dame Venus was implied rather than depicted outright in art.

Sebatian Brant's Das Narrenschiff, published in Basel in 1494, is one of the exceptions to this rule. In the chapter "Of Amours"' ("von buolschafft") Brant describes Venus's influence on various pairs of lovers as they appeared throughout history, citing classical and biblical examples of their foolish behavior at her hands. Dürer's illustration for this chapter (fig. 21) effectively transforms Brant's words into an image, depicting in woodcut the goddess of love holding an ape, an ass, a fool and a cuckoo on leashes; there is a similarity to an earlier print by the Master of the Power of Women (fig. 22). Lovers were fatuous and women were cast in the mold of Venus. Many a male lover and husband would lose honor and money because of woman's sexual power, which in turn was inherited from Venus. Brant writes, in the persona of Venus,

My rope pulls many fools about, Ape, cuckold, ass, and silly lout, Whom I seduce, deceive, and flout. ${ }^{117}$ 


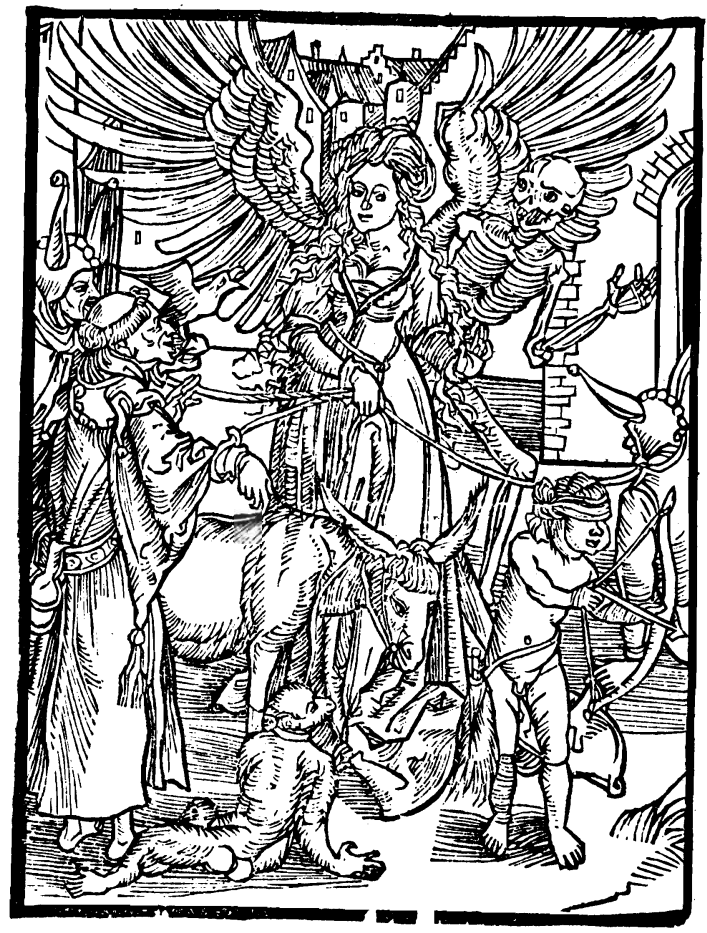

21. Albrecht Dürer, Dame Venus

Holding Cleric, Ass, Monkey and Fool on Leashes, from Sebastian Brant, Narrenschiff, 1494, woodcut

He continues:

Dame Venus, I, with rump of straw, Fools do regard me oft with awe, I draw them toward me with a thrill And make a fool of whom I will. . . . Whom Cupid strikes, Amor ignites, So that the fire his vitals bites And he cannot put out the flame That killed Dido of ancient fame David would not take Bersabë [Bathesheba], Samson would not trust Dalitë [Delilah], As horse the wise man [Aristotle] would not fare And Vergil would not hang in air, ...

Who sees too much of woman's charms His morals and his conscience harms; He cannot worship God aright Who finds in women great delight ... Such love is still more foolish when It seizes older wives and men . . . For wisdom's treasure rich and pure Cannot be mingled with amour; A lover's oft so blind indeed, He thinks no one his loves will heed. Such folly I can but deride, This dunce cap's pasted to his hide. ${ }^{118}$ 
The poet first describes Venus's power to transform lovers into fools and idiots, then cites some ancient examples. He concludes that "woman's charms" come between man and God and that wisdom and love cannot coexist. Furthermore, it is older folk who are the most foolish lovers.

Brant by no means invented the equation of love and folly. In the thirteenth century, for example, folly was already identified with the pursuit of love for its own sake rather than for procreation, the ideal Christian purpose of sex. This view was put forth in the last quarter of that century in the Roman de la Rose (see Chapter 2). There Raison scorns love and desire, since her object is to obtain wisdom or raison. Amis, on the other hand, describes the tools appropriate to lovers-deceit, force, flattery, hypocrisy, contempt of marriage and bribes. ${ }^{19}$ An old woman, La Vieille, is another character in the Roman who imparts a bit of worldly wisdom to her sisters. She recommends "love," not constancy, in affairs of the heart, adding that the former is a good means of acquiring wealth. Thus old age and mercenary love join hands. Elsewhere in the Roman, Jean de Meun states that the old are not allowed to enter the garden of delights. ${ }^{12} 0$

Other ideas were professed earlier by Andreas Capellanus, a twelfthcentury writer of uncertain origin. Andreas's De Amore (1174?), written for Countess Marie of Champagne at the court of Poitiers, 121 is influenced by the Etymologiae of Isidore of Seville (ca. 560-636); Andreas too concerns himself with the origins of words. Amor, "love," he argues, through the character of one Walter, who has never been satisfactorily identified, ${ }^{122}$ is derived from the Latin amus, "hook," since the man who is in love wishes to capture his beloved with a hook. Amor is the type of unworthy love that Andreas describes as "bent by sensual desire."

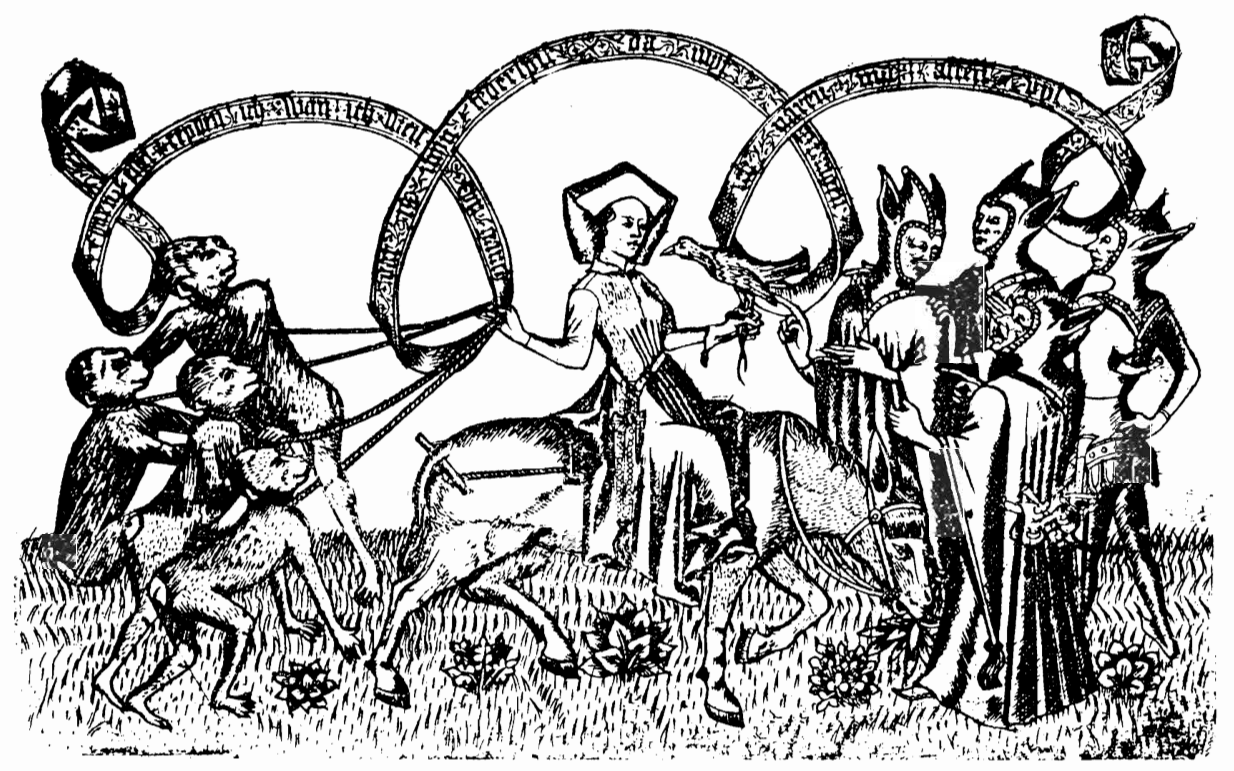

22. Master of the Power of Women, Dame Venus Holding Cuckoo and Fools and Apes on Leashes, ca. 1450-75, engraving 


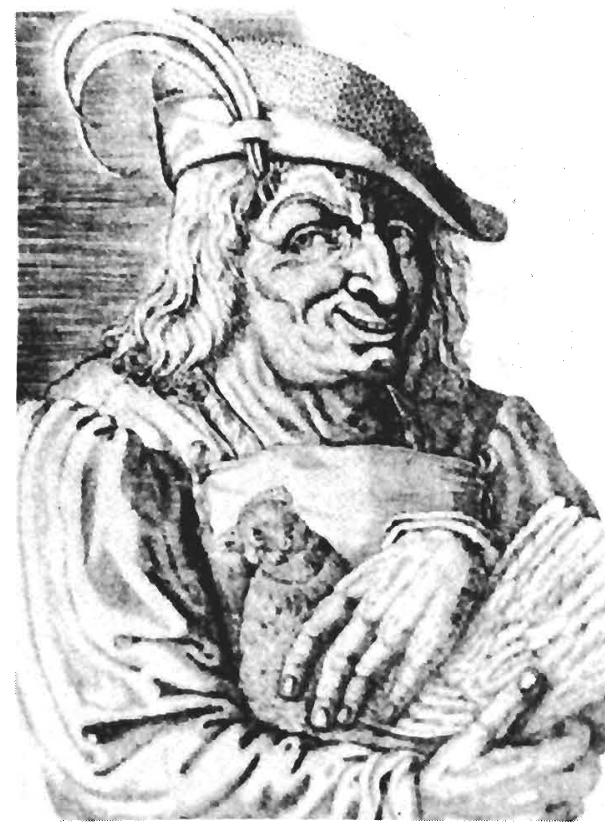

23. Master ISD, Lustful Old Man Fondling

Chicken, ca. 1550-75, engraving

Some six hundred years earlier, Isidore of Seville had proposed that amicus, "friend," derived from animi custos, "guardian of the soul"; this, Andreas affirms, is true love, as opposed to impure sensual desire. Andreas alerts his audience to the dangers of lust, which may impede true love. $\mathrm{He}$ feels that blindness and old age are likely to do the same. ${ }^{123}$

Thus, the notions of lust as a trap, and of the particular susceptibility of the old, were by no means new when Unequal Couples first entered the pictorial arts of the late fifteenth century in northern Europe.

\section{Lustfulness of the Old}

The attitude that lust is unbecoming to the old, especially in light of the wisdom that is expected to accompany old age, probably goes back to antiquity. It was not, however, explicitly depicted in northern art until the last quarter of the sixteenth century when, for example, the monogrammist ISD, active in Antwerp as an engraver around 1546-80, executed a lustful old man fondling a chicken (fig. 23). ${ }^{124}$ This visual metaphor for lascivious activity is inscribed: "And do not feel my little hen too closely/For it would become somewhat like a sprout."'125 Cornelis Bloemaert (1603-84) depicted a similar idea; we are to "see how the old man feels the hen,/A dried up old hag[?] would also like to do something.",126

Approximately a century prior to these works, Sebastian Brant stated that the old were foolish and that old men in particular demonstrated their folly in lust.

My foolish conduct mocks my age,

I'm very old but am not sage,

A naughty child of hundred years,

A youthful dunce cap o'er my ears; . . .

Old age today is bare of sense.

Susannah's judges showed us why

On older men we can't rely. ${ }^{127}$ 


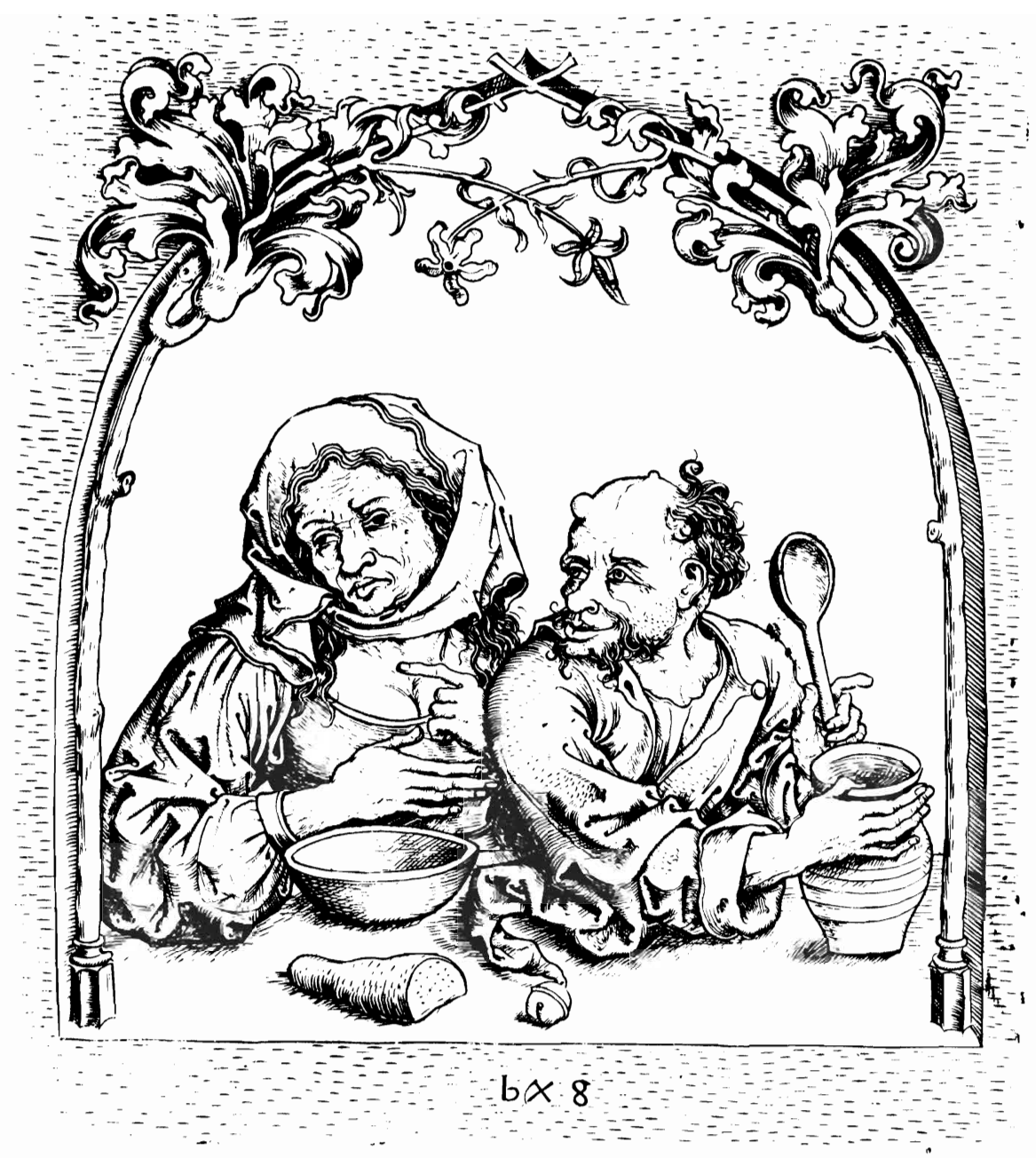

Examples of lustful old people can also be found in northern art before 1500 , though they seem to be more symbolic than explicit. An engraving by Master bxg, based on a lost work by the Housebook Master that may represent the popular fifteenth-century comic pair Marcolf and Polikana, ${ }^{128}$ depicts an old couple in half length with bowl, bread and jug set before them (fig. 24). An engraved copy by Nicolas de Bruyn (1571-1656; fig. 25) is inscribed: "I eat like a pig and stuff my belly with mush and still

25. Nicolas de Bruyn, Old Woman and Old Fool with Bread and Mush (Marcolf and Polikana?), ca. 1600-25, engraving

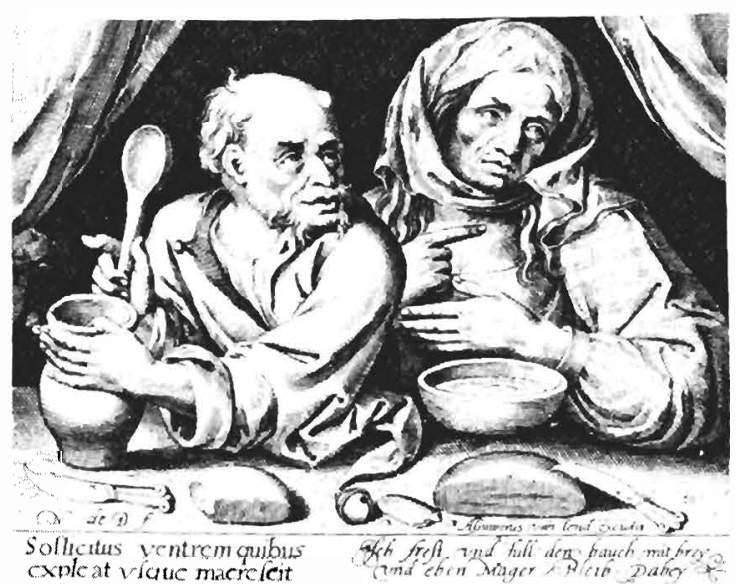


remain thin." ${ }^{29}$ Bruyn here adds an additional loaf of bread, changes the shape of the two knives and loaf of bread, and adds mush to the bowl. The inscription, which implies that some other activity-probably lovemakingkeeps the couple's weight down, may reflect the meaning of the original by the Housebook Master, especially since the verb "to eat" was a metaphor for sexual activity in Germany at that time. ${ }^{130}$ Moreover, the bread, not mentioned in the inscription, may have been understood as a symbol of lasciviousness. A classical expression in Terence's Eunuchus, probably known in German, since it has come down to this century, has it that "without Ceres and Bacchus Venus freezes."131 In other words, love requires bread and wine. Sebastian Brant tells us too that wine usually leads to fornication. ${ }^{132}$ The jug may have had similar connotations, as well as associations with the foolish-and the old man wears bells and carries a spoon, both attributes of the fool. ${ }^{133}$ Bells were common trim on the fool's costume in the later Middle Ages, and the German word for spoon, Löffel, at the time meant fool as well. The old woman carries no specific attributes of the fool, as was usually the case with women; perhaps folly was seen as a natural part of the female character. The low-cut dress and long unbound hair of the woman, both considered more appropriate for young women, may have been the older female equivalent of bells and spoon.

Two female fools, identified as such by the inscription "Narryn," are included in two Austrian tarot cards of about 1453-57. These women carry none of the traditional attributes of the fool: instead, one raises her dress and exposes her calves; the other sports uncovered unbound hair and holds a mirror. ${ }^{134}$ Some seventy-five years later, Hans Sebald Beham engraved male and female fools together (see fig. 29).

26. Master bXg, Old Peasant Couple Carrying Loaves of Bread and Jug, ca. 1475-1500, engraving

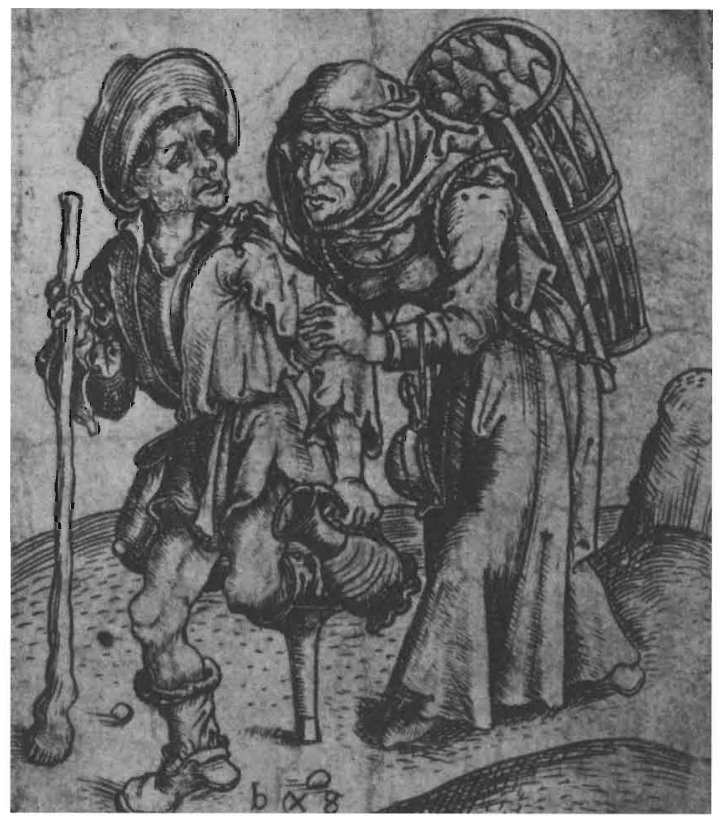




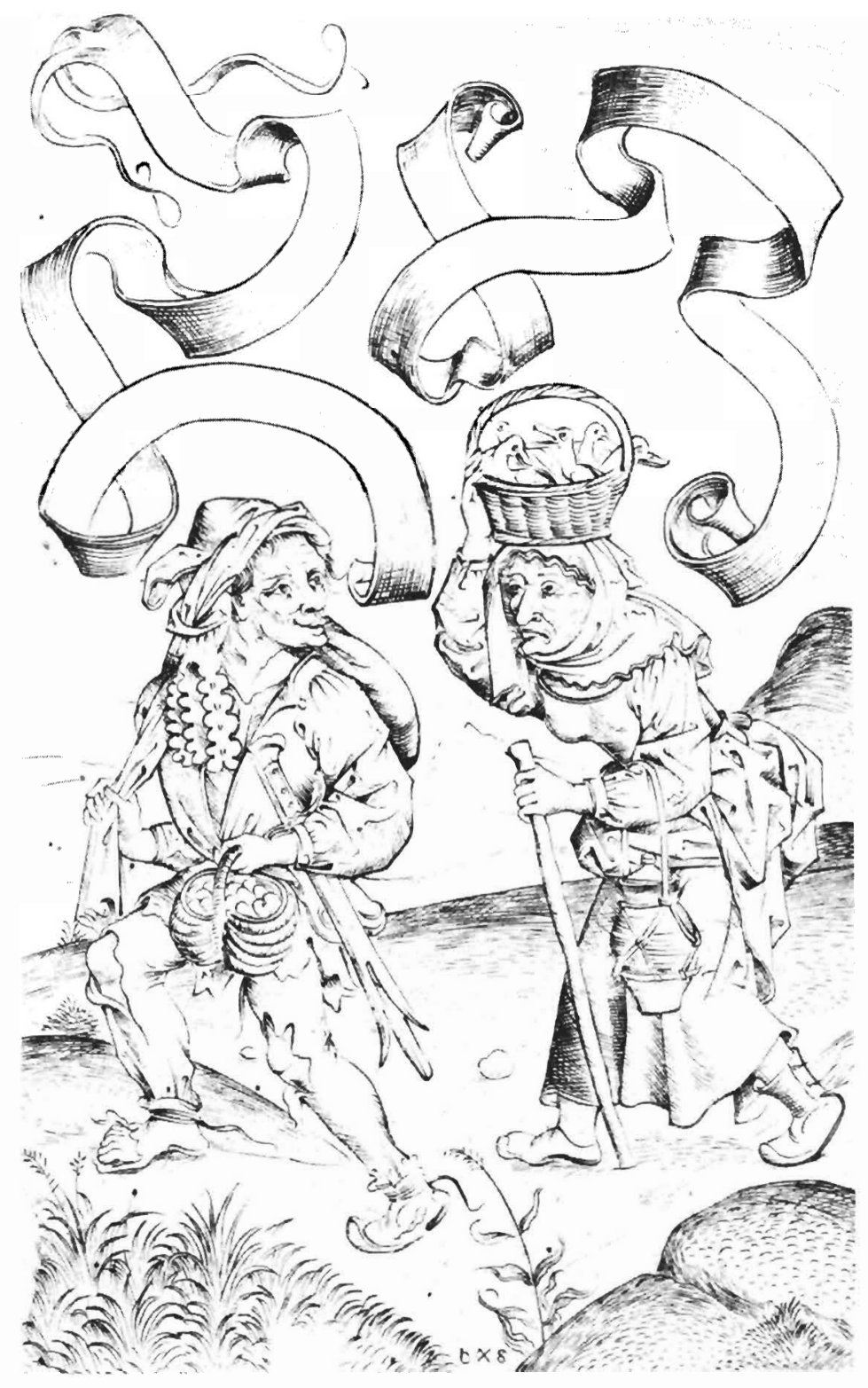

27. Master bxg, Old Peasant Couple Carrying Ducks and Eggs, ca. 1475-1500, engraving

Master bxg depicted a number of old couples, including a decrepit beggar couple (fig. 26). ${ }^{135}$ The woman, who dangles a flask from her arm, is bent over by the weight of her backpack filled with long loaves of bread. As we have seen, the bread is probably symbolic of lust, and represents more than a tendency toward genre.

The most covert sexual symbolism in Master bxg's engravings of lustful old people is to be found in one that depicts a peasant couple carrying eggs and ducks as if en route to market (fig. 27). The sexual connotations of 


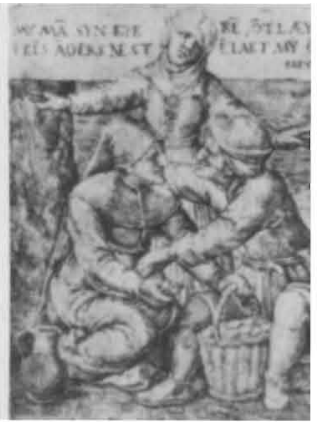

28. Cornelis Massys, Allegory of Adultery:

Woman Taking Basket of Eggs from Another

Woman's Husband, 1549, engraving

the noun bird are still current today, and the verb, "vögeln," was obscene, meaning "to copulate." Ducks and other waterbirds were probably considered the most lustful of all birds. ${ }^{136}$ This seemingly innocuous engraving may, therefore, have once more signified the lustfulness of the old. Like the Unequal Couple, it may well have been a visual representation of current ideas.

Eggs were viewed in a similar sexual light; to this day they are symbols of fertility. In the context of such works, however, eggs probably functioned as emblems of sexual activity or of the male's testicles. A fifteenth-century carnival play employs this double meaning of eggs and speaks of the male member as the eleventh finger with eggs attached ("dem ainliften finger/Und die eier, die daran kleben"). ${ }^{137}$ Brant tells us as much in the chapter called "Of Adultery" ("von eebruch"). If Menelaus had not given his hospitality to Paris, Brant points out, Helen would not have been carried off to Troy. If Agamemnon had not left his house to the crafty Aegisthus, his troubles would never have been. Married couples should avoid guests whom they cannot trust:

\footnotetext{
For life's full of strategem... .

A miser's better as a guest

Than other's eggs in one's own next.

Who often far afield will go

A sparrow soon will be, I know.

Who'd boast a lap of burning coal, Whose trusting bosom snakes enfold, Who in his pocket rears a mouse, Such guests are bad in any house.
}

The guest who sleeps with the lady of the house is compared to the cuckoo who lays eggs in the nest of the sparrow. ${ }^{138}$

Eggs can be found in a more explicitly licentious context, one that dates, however, over fifty years later. In this 1549 Netherlandish work by Cornelis Massys (fig. 28), a woman abandons her basket of eggs for a moment, then watches with dismay as it is taken from between her husband's legs by an old woman who gazes fondly at him as he reaches to place an egg in her lap. The wife's lament is inscribed above: "My husband lays his eggs/In the nest of another and leaves me unsatisfied." 
The power of Dame Venus and the lustfulness of the old combined in the last thirty years of the fifteenth century to inspire representations of Unequal Couples that satirized, for the most part, woman's greed and her power to acquire money through the folly of an old man's lust, which in turn prevented his noticing or, for that matter, caring about any expense. The foolishness of the older partner was especially emphasized, and he, or sometimes she, was presented as the dupe of the younger. The younger partner clearly had the upper hand and would have been well aware of the consequences of acquiring money from an older partner. The foolishness of the old at that time was reflected in contemporary Dutch and probably also German expressions ("hoe ouder hoe sotter" and "Alter schützt vor Torheit nicht")—still known today-that are approximately equivalent to the English "there's no fool like an old fool." Early in the development of the Unequal Couple the combination of this idea and the notion of women's power over men transformed into a visual symbol depicting the old lover's unbecoming and foolish behavior: the fool's cap or costume.

The fool or jester had merrily entertained men and women of courts and town since antiquity. The second-century Greek writer Lucian described the fool's appearance in his Lapithae: his head is shaved, except at the crown where a cockscomb-like formation of hair remained. The Roman epigrammist Martial (ca. 40-ca. 104) comments that fools wear long pointed ears on their heads. Another of the fool's attributes, his staff or bauble, was derived from the antique comic actor's long wooden sword. By the fifteenth century, however, the staff had shortened and a fool's face often decorated one end; the bauble varied in shape and assumed simpler forms as well, including that of a leather cudgel that could be hung over the arm. The fool's hood or cap was decorated with ass's ears and bells. The bells were used simply because of their popularity in the late Middle Ages, and were not derived from any antique source. ${ }^{141}$

29. Hans Sebald Beham, Male and

Female Fools with Lewd Bauble, ca. 1530-40, engraving

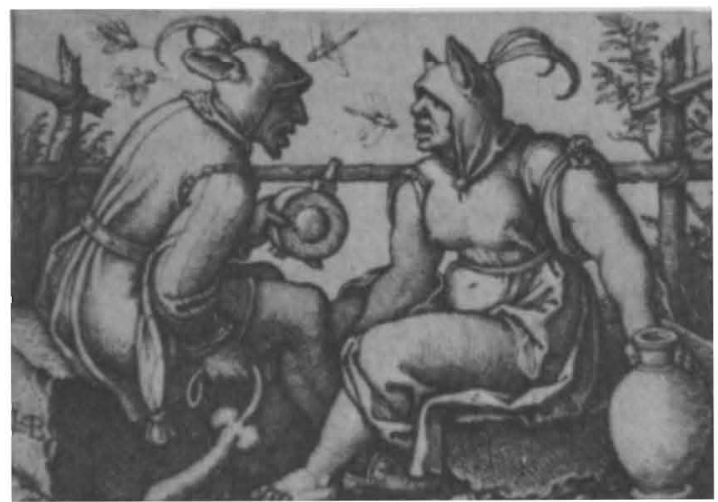


The association of folly and wrong-doing persisted into the Middle Ages. In twelfth-century Germany, wrong-doers were referred to as fools. By the fifteenth century, the insulting words gouch, narr, affe, tore and esel were in common use to describe those who behaved foolishly. ${ }^{142}$

The earliest fools in fifteenth-century northern prints, as in contemporary carnival plays, are depicted in sexual contexts. The fool is preoccupied with the satisfaction of his sexual desires, almost always as the servant of Dame Venus. Folly was, therefore, linked with sexuality; from the early fourteenth century, the term folly meant lewdness. This association is suggested by the European court jester's having a bladder shaped like a phallus attached to the end of the bauble (see fig. 29). In addition, the English fool is believed to have derived etymologically from the Latin follis, meaning bellows, windbag or even scrotum. Willeford quite convincingly suggests that the connection between foolishness and lewdness is reflected in contemporary obscene expressions ("balls!" meaning "nonsense "). ${ }^{143}$

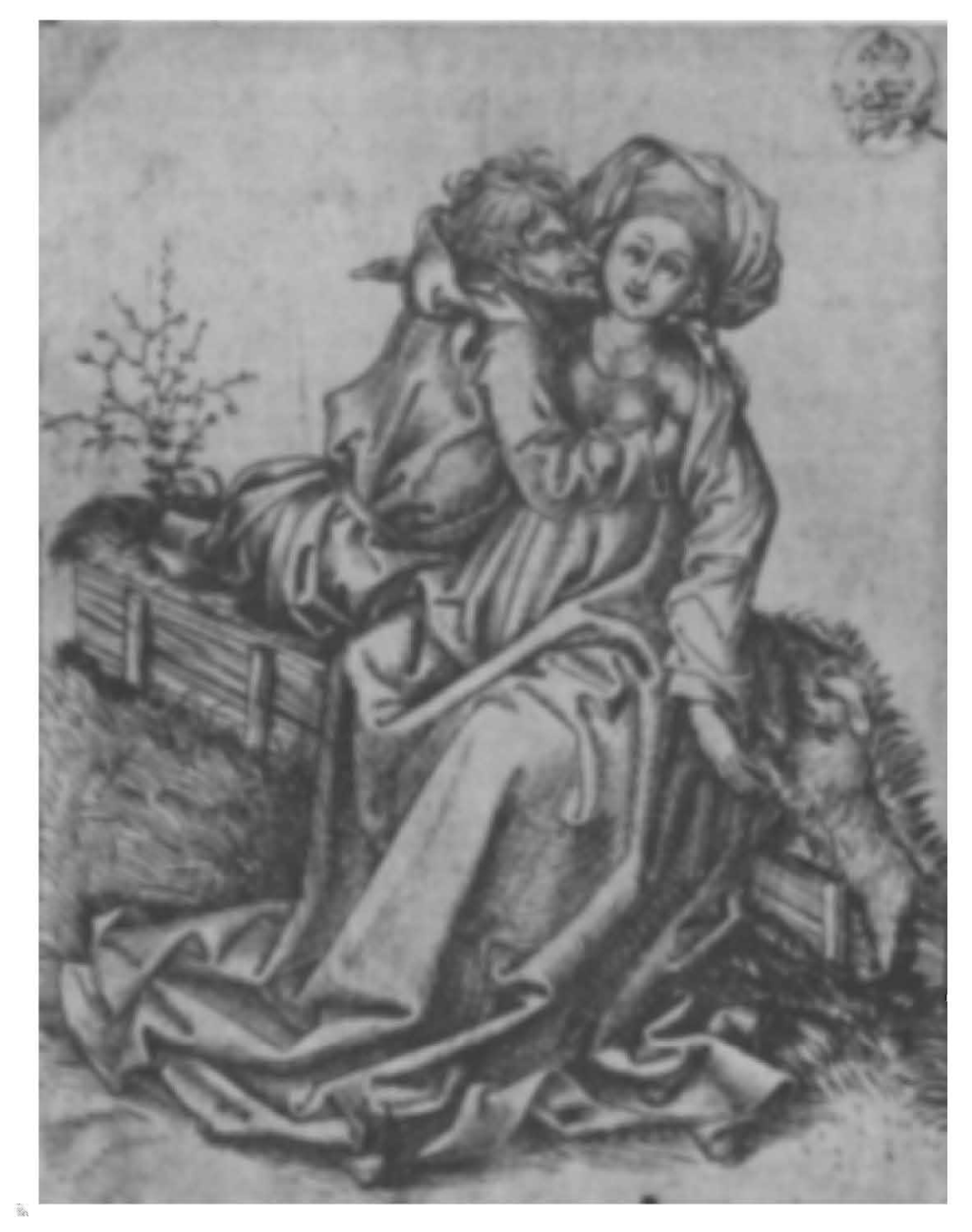


31. Master of the Power of Women, $\mathrm{Na}$ ked Woman with a Rose, 1450-1475. engraving

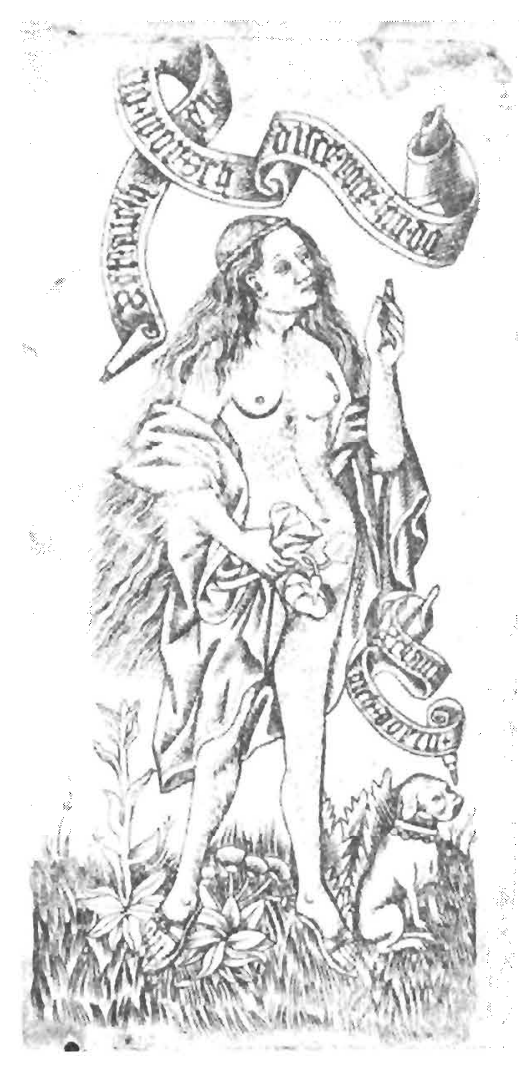

The fool seems to have been at once a comic and a lewd figure, as in Master bxg's Old Woman and Old Fool with Bowl and Jug (fig. 24). The old man's behavior in representations of Unequal Couples was probably considered foolish from the first, yet was not specifically depicted as such until the 1490s, when Dürer and Master B R executed a woodcut and engraving of the theme. Master B R's work (fig. 30) represents an old fool decorated with a fool's cap. He holds a young woman in a lascivious embrace. The placement of the man's right hand under her arm has recently been interpreted as indicating his lustful and good-for-nothing character. ${ }^{144}$ She is attended by a dog, who is standing nearby on its hind legs, and who probably represents.luxuria, in keeping with the association of folly and lust.

Similar lapdogs can be found in Hans Memling's Bathsheba and Vanity where two full-length nude women are each accompanied by a small dog. ${ }^{145}$ Most interesting and to the point is the Master of the Power of Women's engraving, Naked Woman with a Rose (fig. 31). There, a woman, naked except for a large swath of drapery, holds a rose before her genitals, while a dog is seated in the grass to the right. The curling banderole above her states, "Everybody look where I put this rose," while the smaller banderole over the dog is inscribed, "Shame on you.", 146 It is also interesting to note that lapdogs were later owned by Italian courtesans, a custom that suggests that this little dog may signal that the woman is a prostitute. ${ }^{147}$ 


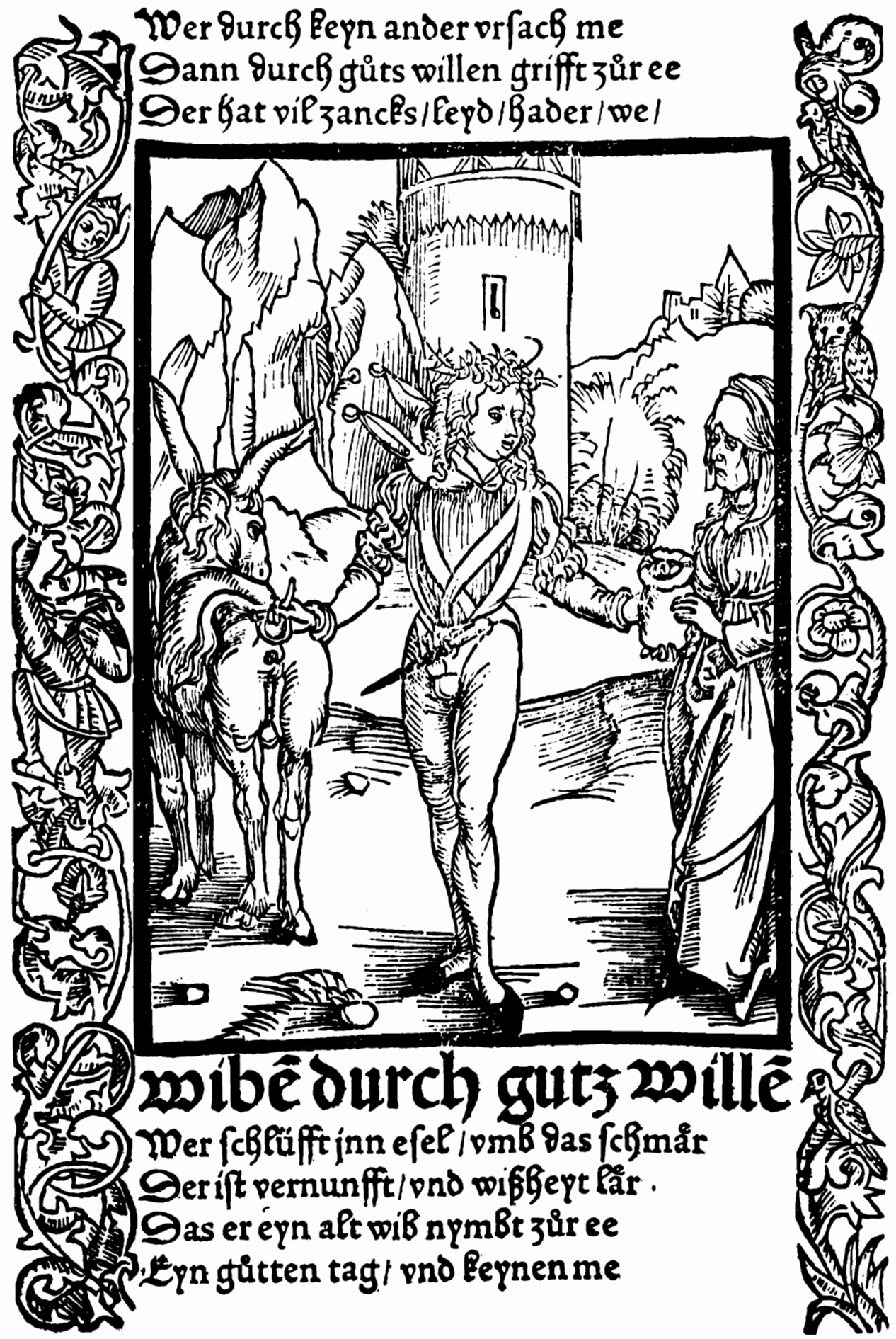

32. Albrecht Dürer, Old Wife and Young Fool, from Sebastian Brant, Narrenschiff, 1494, woodcut 
Dürer's 1494 woodcut from Das Narrenschiff (fig. 32) likewise represents the male lover as a fool, though here the fool is a foppish young man. Brant clearly states the reason for the young man's folly-marrying an old woman for her money. The gaily dressed lad, replete with fashionable long locks, wears a cap decorated with ass's ears and trimmed with bells. $\mathrm{He}$ grasps the tail of the ass on the left, while holding on to the money sack offered by the old woman on the right, which also marks him a fool. This gesture is a literal illustration of images used in the poem to typify absurdity and senselessness: flaying a donkey for its fat and marrying an old woman for her money. In the preamble tristich Brant warns:

Who weds and for naught else is fain

Than growth of property and gain

Will suffer quarrels, woe, and pain. ${ }^{148}$

The poem proper begins below Dürer's woodcut and reads:

Who flays a donkey for its fat

He has no brains beneath his hat, Who weds an old wife just for gain

Makes one grand splurge, then ne'er again,

And he has very little joy,

No children, either girl or boy

And happy, carefree days he lacks

Save when he sees the money sacks. ${ }^{149}$

Brant's conservative, moralizing attitude may well be contrasted with the more carefree, humorous approach of Master B R's engraving (fig. 30), which is more related to the lighthearted, comic tone of German carnival plays. Though both literary sources are satirical, Brant equates folly with sin, and this sets his work apart from the more popular and raucous plays. Brant's warning is clear: don't marry an old woman for her money, because that will be your only reward, and it is certainly no consolation for living with an unbearable shrew. Brant has some doubts about a young man who sells himself for pelf, but his emphasis is on the dreadful life that the young man will have to endure with his old wife. Once again the woman, even though here she is the old partner, is viewed as the worse of the two, this time on grounds of physical decrepitude and personal unattractiveness.

The basic two-figured Unequal Couple expanded around 1511-Urs Graf then designed the earliest extant Love Triangle (fig. 6) and Jacob Cornelisz. van Amsterdam painted a composition that includes both sets of Unequal Couples and a fool (fig. 33). ${ }^{150}$ Jacob Cornelisz. was active in Amsterdam during the first third of the sixteenth century. Some fifty years ago his painting was dated soon after 1511 , on stylistic grounds. ${ }^{151}$ In the background of this representation, the first Unequal Lovers with a sense of interior space, a fool can be seen over a balustrade inscribed " $L X$ SIIN TIIT. " This expression, condensed from the Dutch "elk sijn tijt," proclaims that in time everyone becomes a fool. The punning abbreviation of " $e l k$ "' 


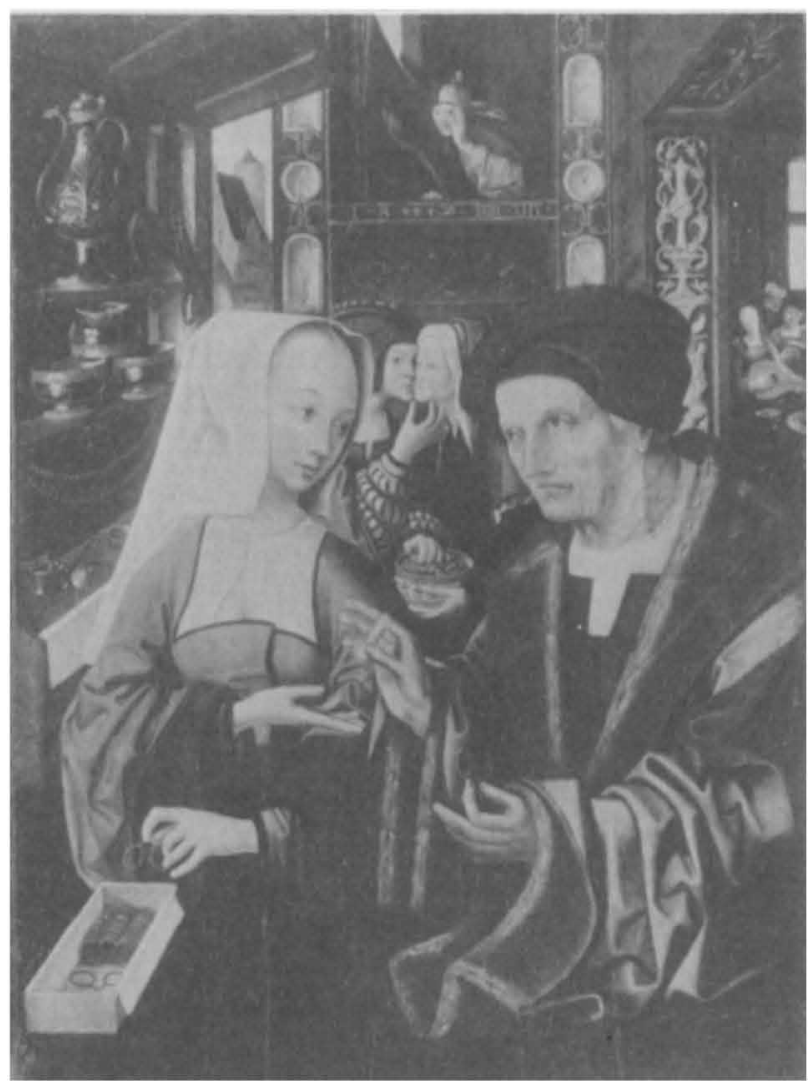

33. Jacob Cornelisz. van Amsterdam, Young Woman Selling Spectacles to Old Man and Young Man Embracing Old Woman, with a Fool, ca. 1511 , panel, Groningen, Museum van Oudheden

into the Roman numeral " $L X$ " was probably intentionally utilized to indicate the folly of sixty-year-olds.

The fool holds his bauble in one hand while looking through the fingers of the other. This gesture is used by people who are unable to recognize a fault as such, 152 and in this context the fault may be adultery, as in Dirrer's illustration of that chapter in Brant's Narrenschiff. In the Dïrer woodcut a fool looks through his fingers while a young woman, probably his wife, tickles his nose with a reed, implying distraction through flattery. ${ }^{153}$ The gesture was also used in a later Unequal Couple (fig. 34) by the Petrarch Master (Hans Weiditz). Brant's chapter 'On Adultery” begins:

If through his fingers one can see And lets his wife promiscuous be, As cat she views the mice with glee. ${ }^{154}$

The lovers' folly, indicated by the fool in the Cornelisz. painting, is enhanced by the activity of the couple in the foreground. There a young woman sells a pair of pince-nez glasses to an old man. The Dutch expression "'brillen verkopen," like the German "jemand Brillen verkaufen," means 


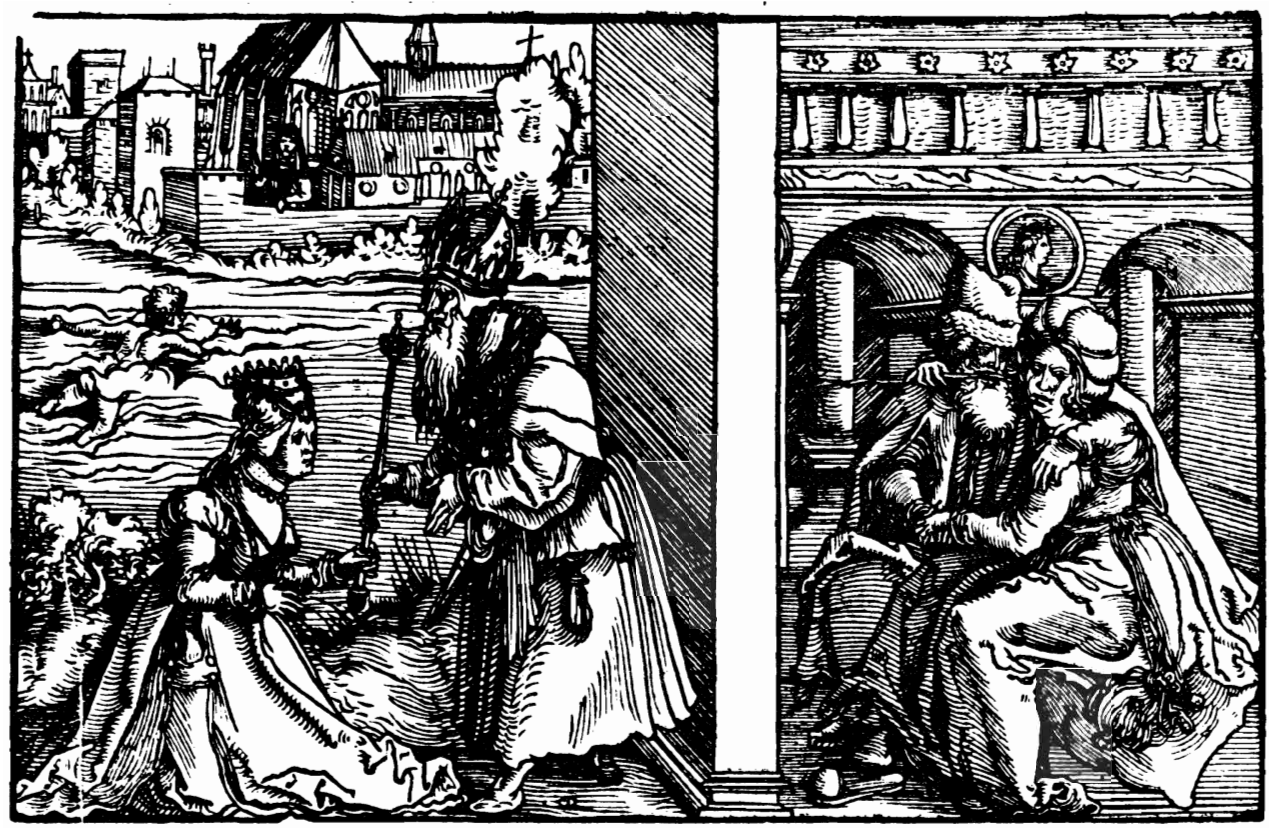

34. Petrarca Master (Hans Weiditz), Young Woman Flattering Old Man by Tickling his Nose with a Reed, ca. 1520, woodcut

both "to sell glasses" and "to fool through deception",15s and its illustration here underlines the foolishness of the old man. The artist may also have intended to indicate that the young lovers too were engaged in foolish activity, for another Dutch expression, "hem met een schoon gezicht bedodden" means both "the fool with the beautiful face" and "to fool the person with the beautiful face." 156 The former interpretation is more appropriate, since only the younger partners have beautiful faces. They would certainly have been considered fools for selling themselves to wrinkled old lovers.

The inclusion of two unequal couples within one composition is very unusual. Only one other representation of this type has come down to us, a German woodcut that probably dates from the same decade (fig. 35). The presence of both couples, the satirical tone set by the fool and the general manner in which they are presented, suggest a passage from Erasmus's Praise of Folly, ${ }^{157}$ written in 1509 but not printed until 1511. Dame Folly is speaking:

It is my doing that there are old men everywhere who are as old as Nestor, and scarcely have a man's shape: stuttering, senile, toothless, gray-haired, bald; or in the words of Aristophanes, "Nasty, bent, wretched, shriveled, bald, toothless and sexless." Yet they're so delighted with life and 
they wish so to be thought young, that one dyes his gray hair; another covers his baldness with a wig; another'gets a new set of teeth; another falls desperately in love with a girl and outdoes any young man in nonsense. For nowadays any old dotard with one foot in the grave can marry a juicy young girl, even if she has no dowry-it is so common that men almost expect to be praised for it! But the best of all is to see the old women, almost dead and looking like skeletons who have crept out of their graves, still mumbling, "Life is sweet!" As old as they are they're still in heat, still seducing some young Phaon they have hired for large sums of money. Every day they plaster themselves with makeup and tweeze their pubic hairs; they expose their sagging breasts and try to arouse desire with their thin voices; they drink, dance with the girls and write their silly love-letters. People laugh at these things, as they should; and yet these old women are mightily pleased with themselves, and they live a life of joys and pleasures, and in a word are happy-through my good graces! 158

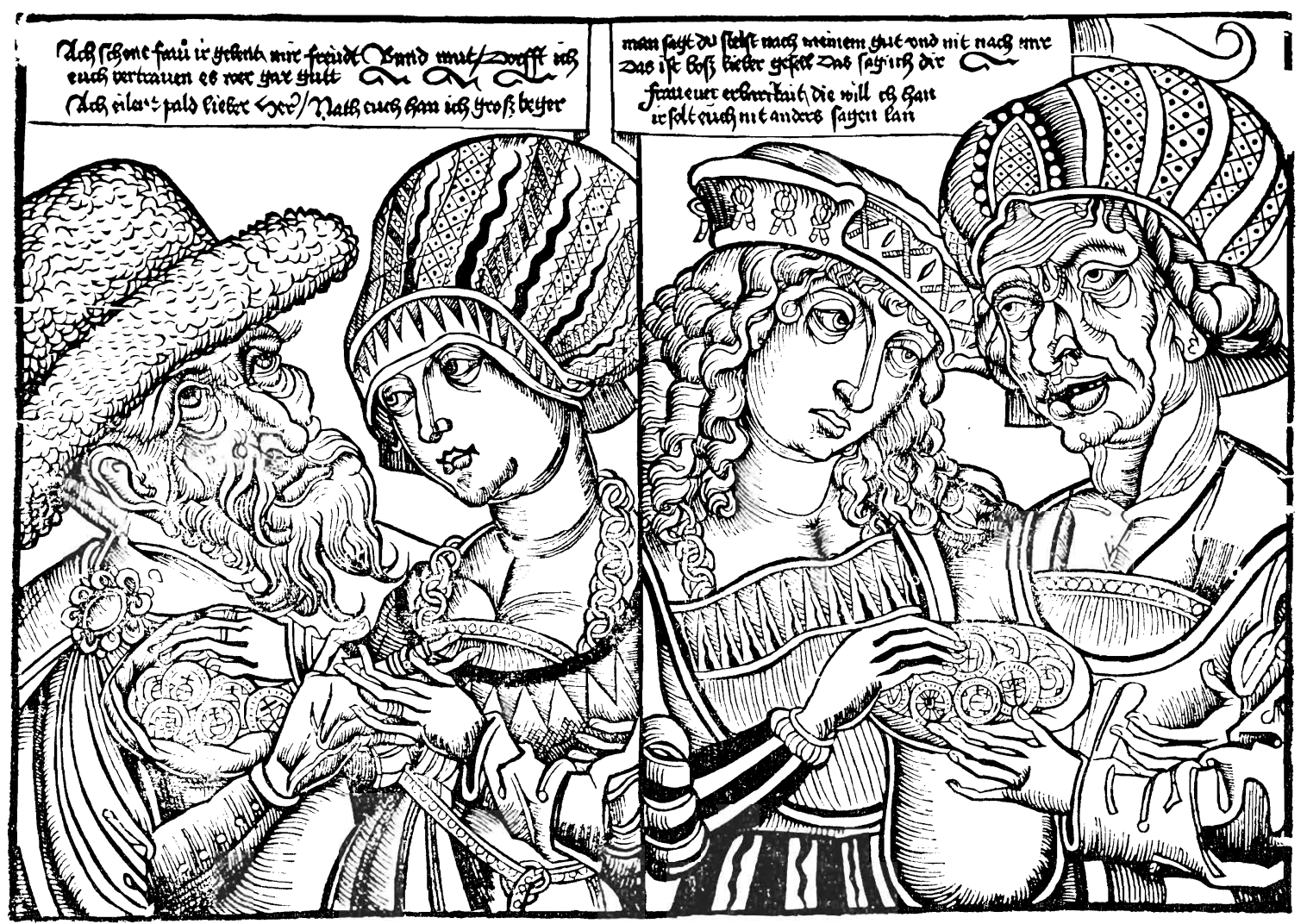

35. Cieman, Old Man with Young W'oman and Yommg Man with Old W'oman, ca. 1510-20, woodcut 
Erasmus mentions, though briefly, both unequal couples together once more, and also remarks on those who would marry a rich old widow for her money. 159

Elsewhere in his Praise of Folly, Erasmus states that folly is "being swayed by the dictates of the passions," a definition that clearly underscores the foolishness of the old man in the Cornelisz. painting, a man whose

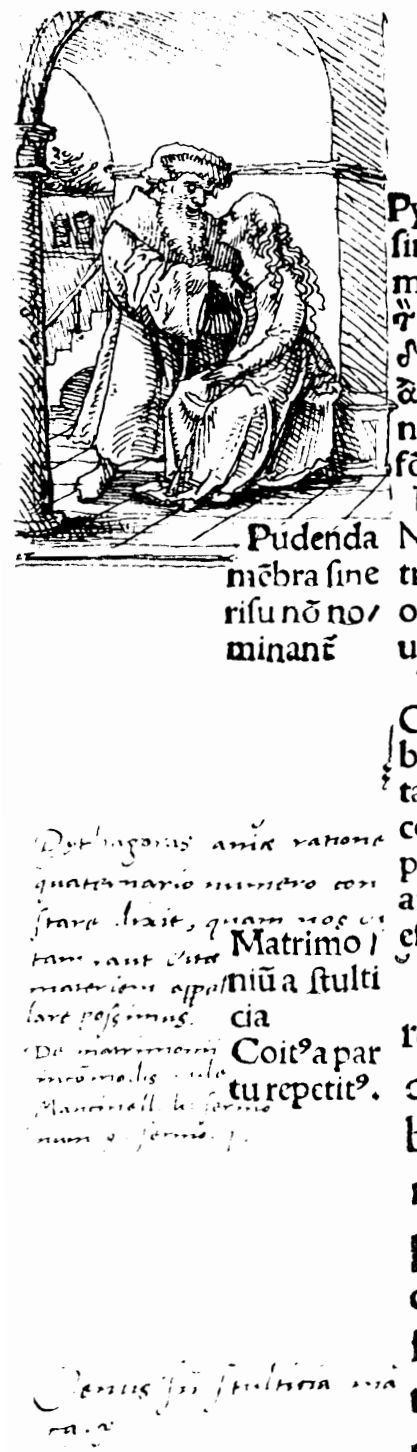

Pythagoricus) Allui fit ad carmẽ uulgatiffi mũ Pythagorx, vai $\mu \dot{\alpha}$

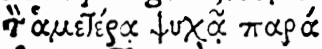
fovT $\pi \varepsilon \xi \alpha x \tau \dot{\psi} \mu \pi \alpha r \alpha \mu$

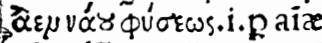
ñ̄̉xdãtem ăternionẽ ōtem ppetux naturx. Reclamãte Lucretio ) Nam is in carmic fuo tribuit Veneri rerum omniũ gignendarum uim, ac principatum. Vulgus Monachos) Quod olim apud $\mathrm{He}$ brros crant filti , pphe tarũ, quod apud Grra/ $\cos 8$ Indos philofor phi,hoc apud Chrifti, anos monachi uident́ efle. At fit fan) Oftẽ, det ftultis
M QPIAE ERKSMION

adamätina, ineptiendum ac delirandiu aliquantifper.In fumma me, me in $\tilde{\phi}_{\mathbf{W}} \sqrt{a}$ piês ille accerfat oportet, fi modo pater effe uelit.Et cur non apertius meo mor re uobifcú fabuler: Quxefo num caput, num facies, num pectus, num $m$ anus, num auris, qux partes honefteputant. progenerant dcos aut homines? Non opinor,imo ca pars adco ftulta,adeo $\$$ ridicula, ut nec noiari citra rifum poffit, hũani generis cft ppagatrix.Is eft facer ille fós, unde uitā hauriút oia ucrius, $\widetilde{\mathscr{C}}$ ille $P$ ythagoric ${ }^{9}$ quternio. Age uero quir obfecio matrimoní capiftro uclit pra, berc os, fi quéadınodü ifti fapiêtes face, re cölucuerunt,pri9 ci' uitx incómoda fecú perpéderit,aut qux tan dé mulicr uirú admiffura fit, fi partus piculofos la, borcs, fi cducationis molc ftiam, ucl norit, ucl cogitarit:Por ro fi coniugî́s debctis uitam, cöiugium autem debetis « «ooiz pediffequa, mihi nimirum quid debeatis, intelligitis. Tum

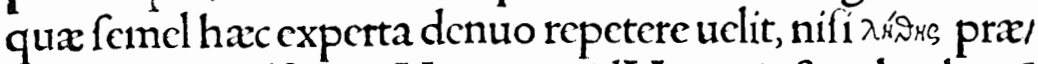
fens nom en adfucrit. Neq; ucro idVenus ipfa ucl redama re Lucretio ur: $\ddot{\beta}$ inficias iucrit, fine noftri numinis accefli o ne, fuam uim mancam atq irritam cffe. Itaq; ex noftro illo temulento ridiculog; lufu,proucniút, \& fupcrciliofi philofo phi, in quorum locum nunc fucceffcre, quos uulgus Xonas chos appellat, \& purpurei reges, \& pij facerdotes. Pooftremo, totus ctiam ille deorú poctico $z$ coetus, adco fiequés, ut tur, Cõmoda bam uix iã ipfe capiat olympus, tametfi fpaciofiflimus. At uitze ex ftul fane parum mihi uitx feminarium, ac fontem deberi, nifi
tucia.

36. Hans Ilolbein the Younger, Unequal Couple: Old Man l:mbracing

Young Woman, drawing from Myconius, Praise of Folll. 1515. Basel.

Kupferstichkabinet 


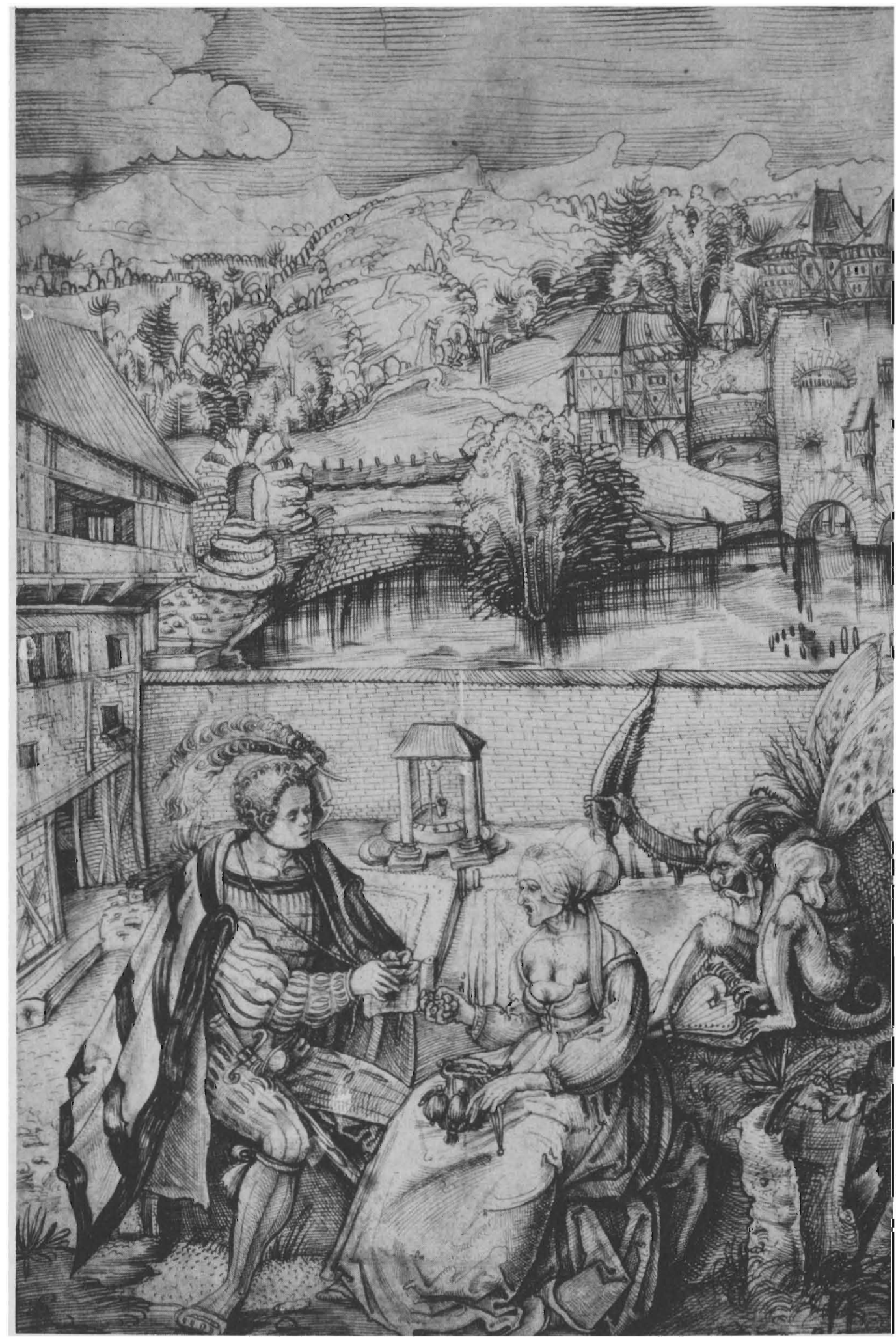

37. Niklaus Manuel, Old Woman, Young Man and a Demon, ca. 1515, drawing, Basel, Kupferstichkabinett, Kunstmuseum 
passion blinds him to reality. 160 Foolishness could have been implied even without the fool or his attributes. For example, Hans Holbein's drawing of an Unequal Couple (fig. 36), sketched for the schoolmaster Myconius's copy of the 1515 edition of Erasmus's Praise, depicts a wealthy old man who fondles the breast of his young companion. Even though foolish behavior is implied, no specific attributes identifying the lovers as such are included. Holbein, curiously enough, juxtaposed this drawing with a text dealing with the folly of marriage in general, rather than with the unequal couples passage.

Erasmus's old people are clearly an object of derision, and there is even less emphasis here on youthful folly than in the Narrenschiff by Brant. Erasmus concentrates on the old and states elsewhere in the Praise of Folly that "nothing is better than youth, nothing so hateful as old age." He goes on to allude to the Dutch proverb, "hoe ouder, hoe sotter Hollander" ("the older a Dutch person the more stupid he or she is"). ${ }^{161}$ Erasmus therefore skillful and humorously rails against the old, indicating, through his satirical approach, that fools may also be young.

The attributes of the fool were sometimes rendered in a less obvious manner. Niklaus Manuel's pen drawing of about 1515 (fig. 37) ${ }^{162}$ depicts an old woman handing a fistful of coins to a young gallant, and contains two possible allusions to her foolishness. Her purse appears to be decorated with an ass's ear with a bell at the end similar to those decorating fools' caps. In addition, a demon is seated behind her, pumping a bellows at her back while readying a wing over her head. Willeford states, and dictionaries confirm, that "windbag" or a "pair of bellows" is the most common derivation for the word "fool," which derives from the Latin follis. ${ }^{163}$ But if this definition of folly was not familiar at the time, the association of the bellows with the devil and lust certainly was. In Durer's Dream of the Idler engraving, which dates around 1498 (fig. 38), for example, a pampered old man sits cozily before a warm stove and dreams of a nude young woman. ${ }^{164}$

His idleness is proclaimed by the pillow under his head, for "idleness is the devil's pillow." Here, as in Manuel's drawing, a demon is responsible for the evil that takes place. Dürer even includes a putto attempting to stand on stilts, suggesting perhaps the futility of an old man's love for a young woman. The association of idleness with lust was noted above for Master B R's engraving (see fig. 30).

It is curious and probably more than coincidental that the lustful motivations of the old people in these two works are related to bellows and heat. Bellows, of course, are used to ignite the glowing cinders of a fire, and they came to be used as visual emblems of the idea of inciting lust or the flames of passion; thus their association with the devil. More specifically, the bellows may be related to the idea of burning with lust, a concept still familiar today, but known since antiquity when Eros was identified with the element fire. ${ }^{165}$ Direr's stove would have served a twofold purpose: as the warm and comfortable inducement to sleep and sloth, and as a physical 
reminder of that which the demon is stirring up with a bellows, i.e., the fires of lust.

Manuel's drawing can only conjecturally be placed within the same realm of interpretation, when we attempt to explain what it is that the demon holds in his other hand. The questionable identification of the object as an

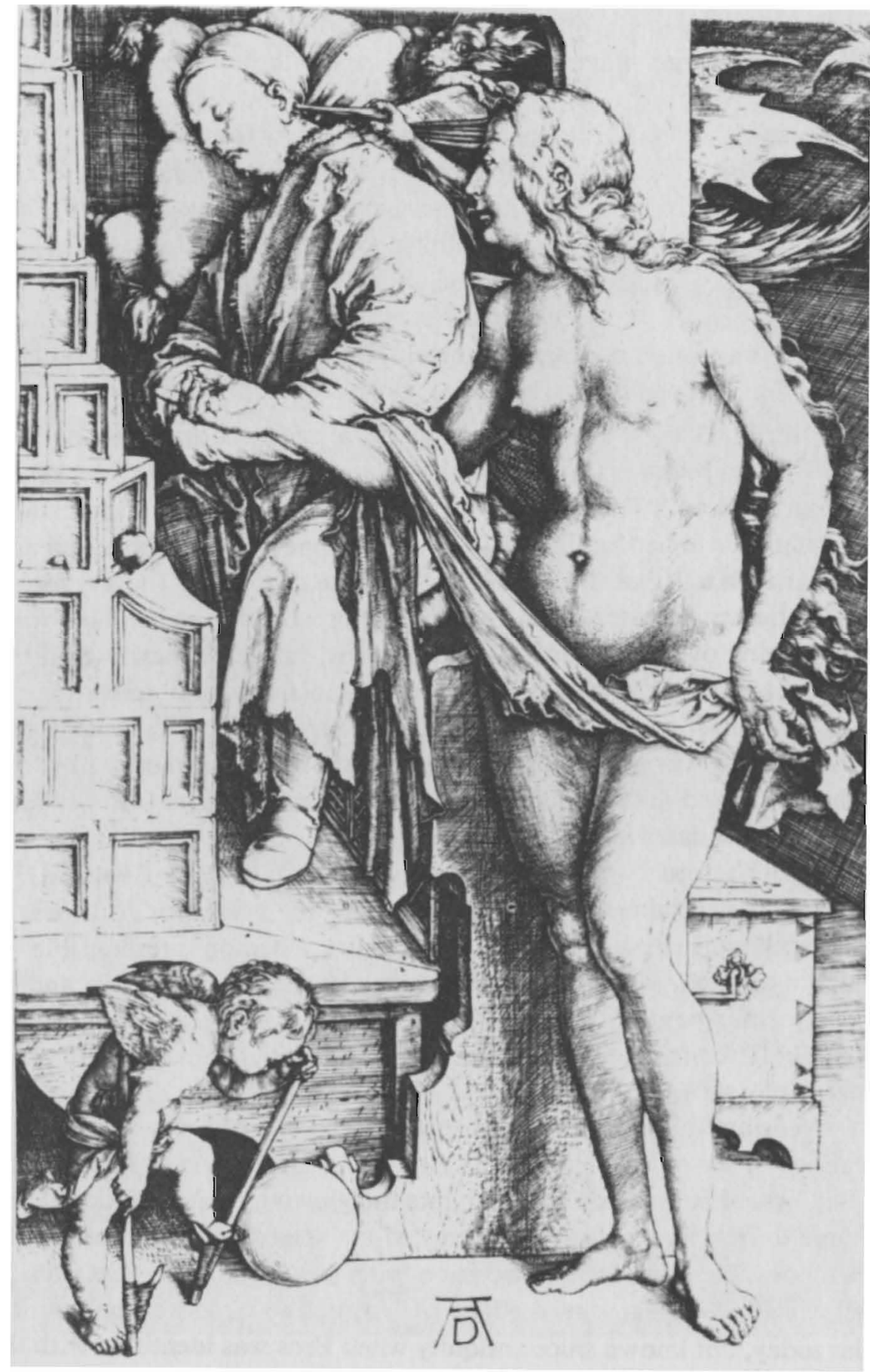

38. Albrecht Dürer, Dream of the Idler, ca. 1498, engraving 


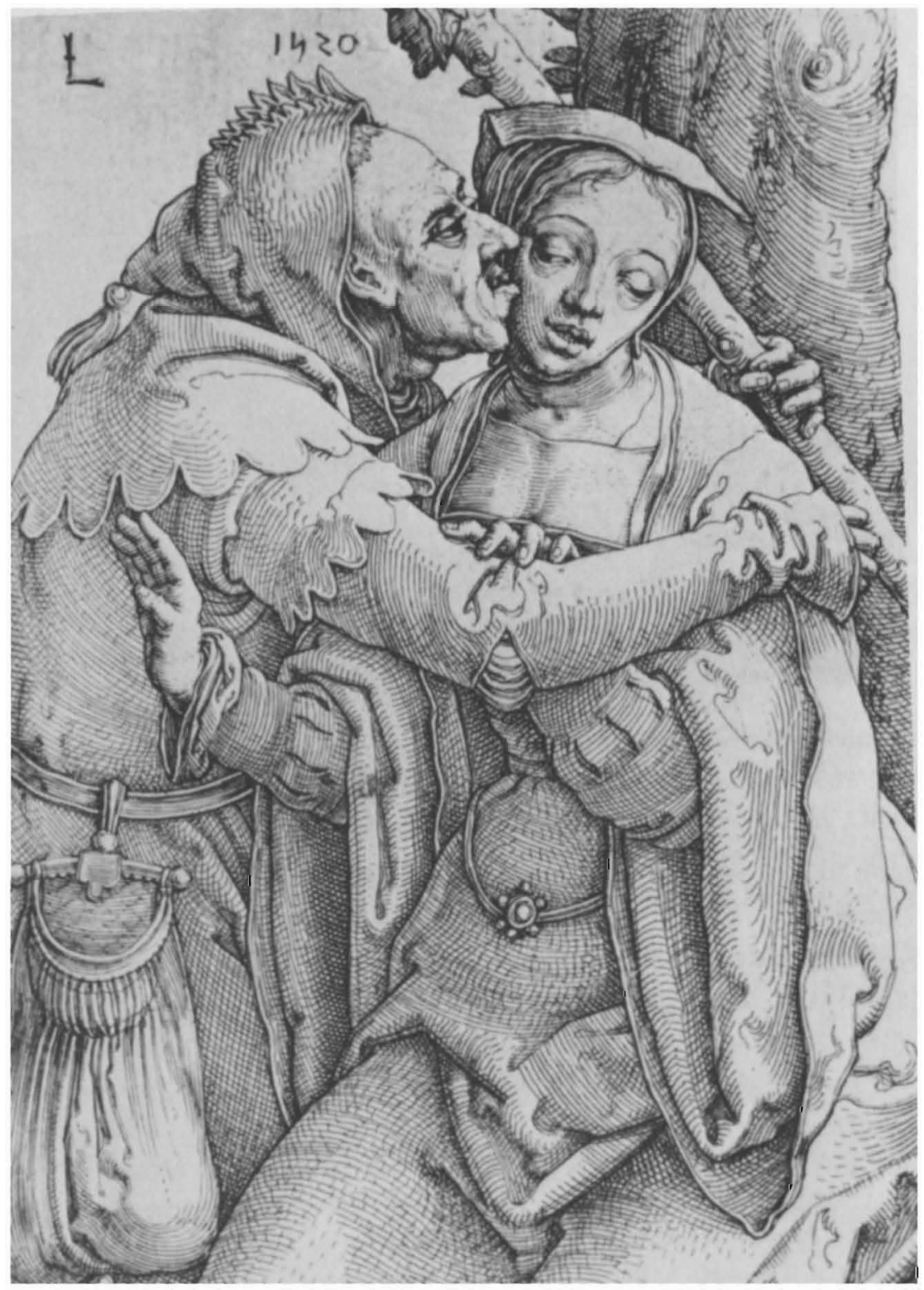

39. Lucas van Leyden, Old Fool Embracing Young Woman, 1520, etching with engraving

ass's ear or, better, a wing, relates this drawing to another, executed in brown ink by Martin Schongauer, signed and dated $1469 .{ }^{166}$ There, a very young woman fans the flames of a fire. If the wing is also related to fire and, by extension, to lust, then the demon encourages the old woman's lust in the Manuel drawing, not only through the bellows, but also through contact with the wing.

The lecherous intentions of the old fool in Lucas van Leyden's 1520 etching (fig. 39) are made clear by his eager embrace and toothy kiss, which recall the engraving of Master B R (fig. 30). His partner's displeasure or even 


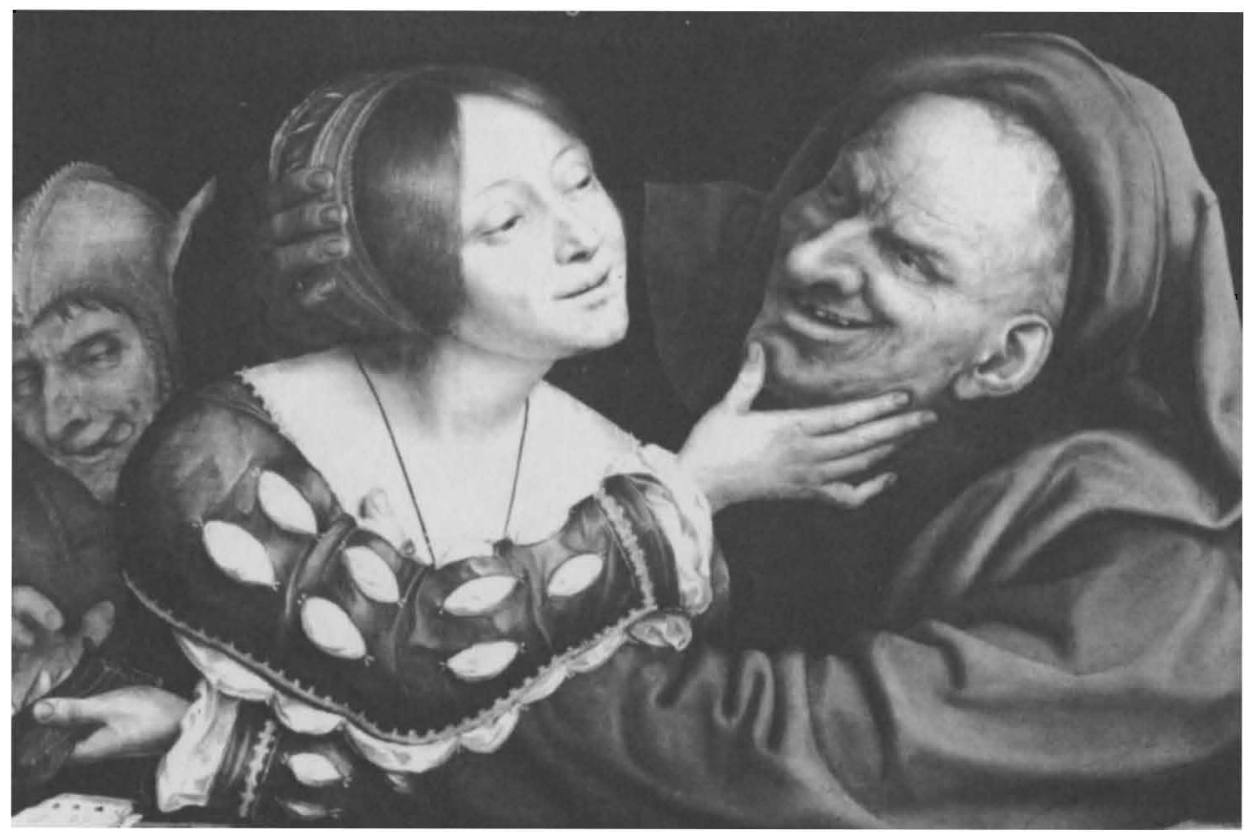

40. Quinten Massys, Old Man, Young Woman and Fool, ca. 1522-23, panel, Washington, National Gallery

revulsion at her unattractive mate is indicated by her hand, raised as if in silent protest.

Quinten Massys added the fool to the basic Unequal Couple composition in his panel of ca. 1522-23 (fig. 40). ${ }^{167}$ Departing from the standard vertical format, Massys juxtaposes a grinning, stubble-faced old man with a young, smooth and pale-skinned beauty, whom he gropes as she passes his purse to her accomplice, a fool. Earlier (fig. 33), Jacob Cornelisz. had portrayed the fool as a character distinct from the two unequal lovers. Massys's fool, on the other hand, is actually involved in the action, not just looking on. Massys thereby expands the basic two-figured composition into a quasi-Love Triangle, one that adheres in its basic form to the half-length close-up arrangement of the Unequal Couple. The pack of cards at the left indicates that love is depicted as a game between the sexes, a theme that was dealt with earlier in Israhel van Meckenem's Card-Playing Couple and in Master M Z's The Ball, both engravings from about 1500. ${ }^{168}$ In Love Triangle in a Card Game Outdoors painted by Lucas van Leyden (fig. $41),{ }^{169}$ the theme is represented once again.

It is interesting that Massys's inclusion of the fool as a new member of the Unequal Couple composition may have been a response to the same literary source that seems to have inspired the Cornelisz. painting, despite the ten or twelve years that separate them, although the response is not to a specific passage. In the Praise of Folly, Erasmus rails in humorous, satirical 
prose against the foolish old men and women who paint and redo themselves in order to attract and woo young lovers. He even includes physical descriptions of such old men, adding that their taking young wives is common practice. But the woman in Massys's painting seems to be using her charms, rather than the makeup that Erasmus mentioned, to obtain the old man's purse. Likewise, Massys seems to have been unaffected by Erasmus's discussion of such a couple's marrying, for he makes no mention of it. Massys's reliance on or relation to Erasmus's text then seems to be general, drawing on its satirical tone, and the concept of folly it expresses.

Another section of Erasmus's work may have influenced Massys more directly, for it deals with the contrast in appearance between old men and young women. Woman's beauty is a powerful and important tool, but it is also a manifestation of her lack of wisdom:

In the first place [women] have the gift of beauty which they rightly value above everything else, for it ensures their power to tyrannize over tyrants themselves. Besides, that unkempt look, rough skin, bushy beard and all the marks of old age in a man can only come from the corrupting influence of wisdom, seeing that a woman always has smooth cheeks, gentle voice, soft skin and a look of perpetual youth. ${ }^{170}$

Massys may have also been familiar with other contemporary Netherlandish literary sources, such as prose novels and rederijker (rhetorical) drama, which employed, respectively, concrete and allegorical figures. ${ }^{171}$ Especially noteworthy is a rederijker poem by an Antwerp colleague of Massys - both were members of the Saint Luke's guild

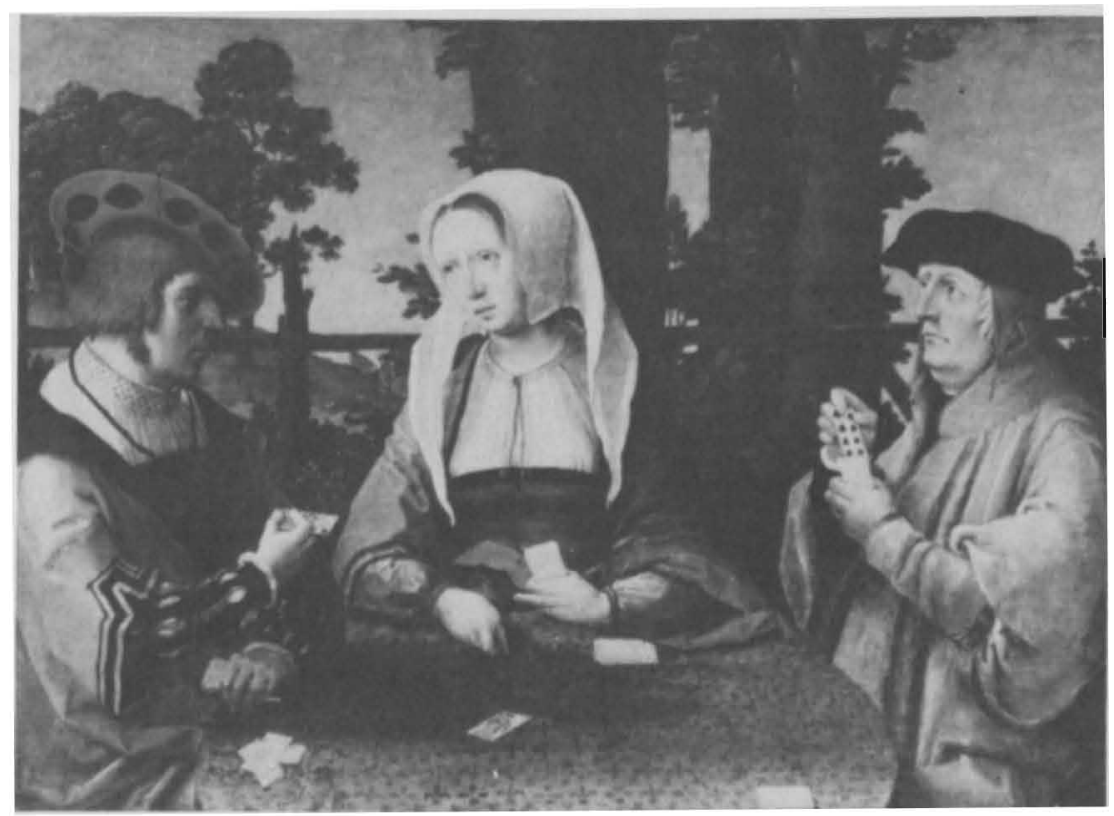

41. Lucas van Leyden, Love Triangle in a Card (iame Outdoors, ca. 1512, Castagnola, Thyssen-Bornemisza Collection, Schloss Rohoncz Foundation 


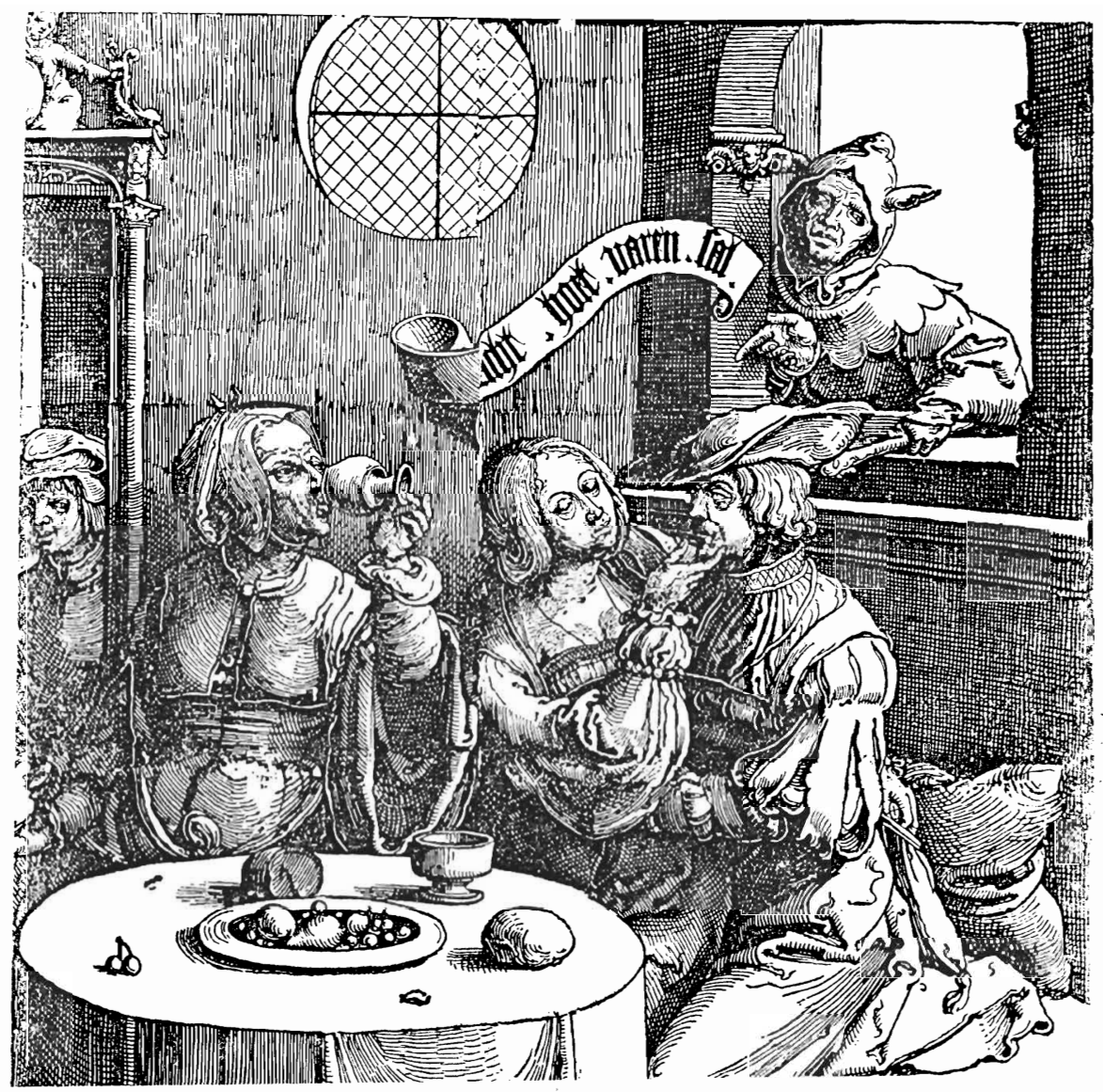

42. Lucas van Leyden, Prodigal Son(?) in a Tavern: Young Woman Passing Old Man's Purse to Her Accomplice, ca. 1519, woodcut

beginning in 1508-named Jan van Doesborch, who later became a leading painter and publisher. He printed the following poem around 1530, but Massys may have known it even earlier; it may have influenced his rendering of the couple's contrast in appearance, as well as the inclusion of the cards for "spoilsport."

A rover-short, old, and free, With purse running over with gold, Took a Venusberg lass for a spree Who took clients like him in her hold. That lass has her loose, lowly wiles, Undoing his purse with its glut, While showing a face full of smiles, Like the grin of a flat halibut. And she wouldn't arrange place or date, For she had to sit home in her chair, Despite whispers before it got late. In exchange, she taught "spoilsport" for pairs, So he had to go seeking elsewheres. He's no wiser, despite this mean trick; Eat your fill when you're offered your pick. ${ }^{172}$ 
It is interesting to note here that Massys, in his panel, adopted the basic form of the embracing couple from Lucas van Leyden's woodcut of around 1519, The Prodigal Son (?) in a Tavern (fig. 42). In Lucas's print, a fool points to the couple, proclaiming "wacht hoet varen sal," that is, "wait and see which way the wind turns." 173 Massys combined the figure of Lucas's fool and boy-accomplice for his own fool, the recipient of the old man's purse. 174

Three prints of around 1525, each depicting a Love Triangle, share with the Massys painting a three-figured core group. An etching after Lucas (fig. 43), a Nuremberg woodcut by Erhard Schön (fig. 44), and an engraving formerly attributed to the Crayfish Master (Frans Crabbe van Esplegem; fig. 45), each impart the sense of a domestic cuckolding, for not only are the prints set indoors, but in each a fool indicates with the "horns" gesture that the old man is being sexually deceived by his young partner, and with the assistance of his own money.

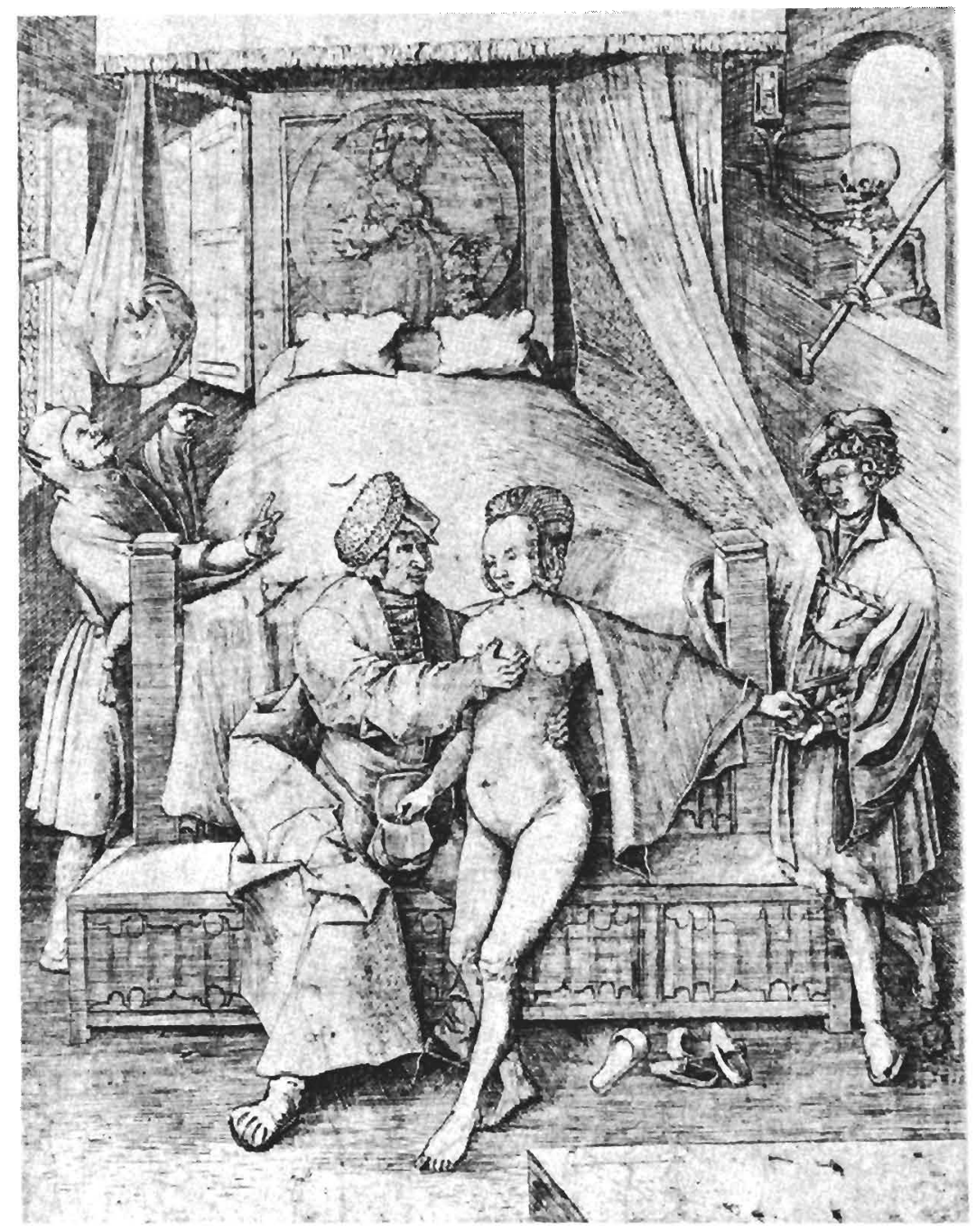

43. After Lucas van Leyden, Love Triangle in a Bedroom with Death and a Fool, ca. 1520-1530, etching 


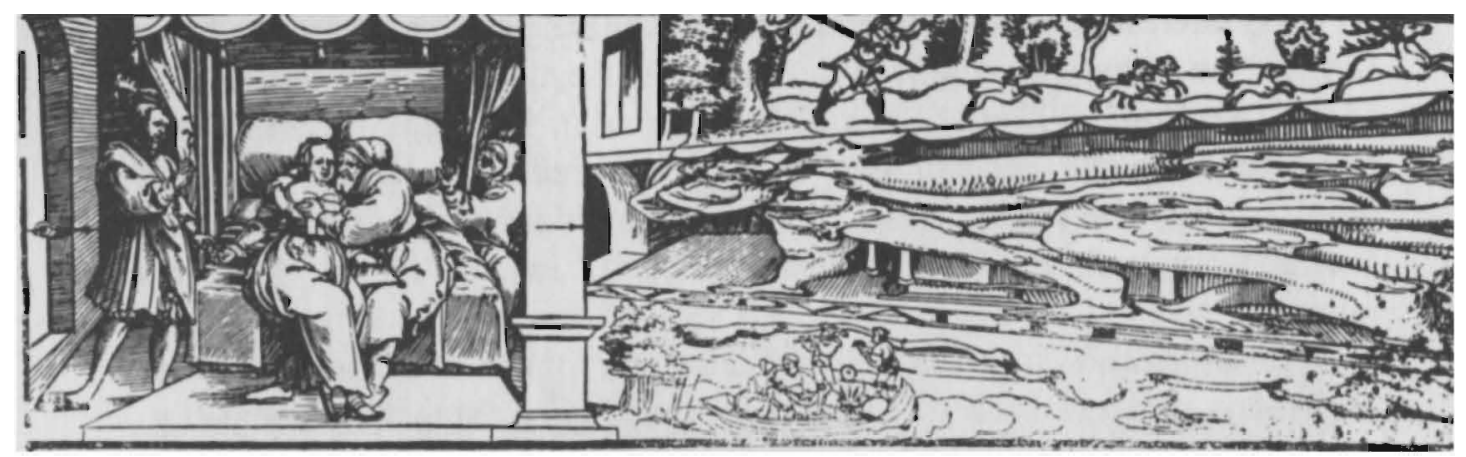

44. Erhard Schön, Love Triangle with a Fool with Anamorphic Old Woman and Young Man: "What do You See?" 1538, woodcut

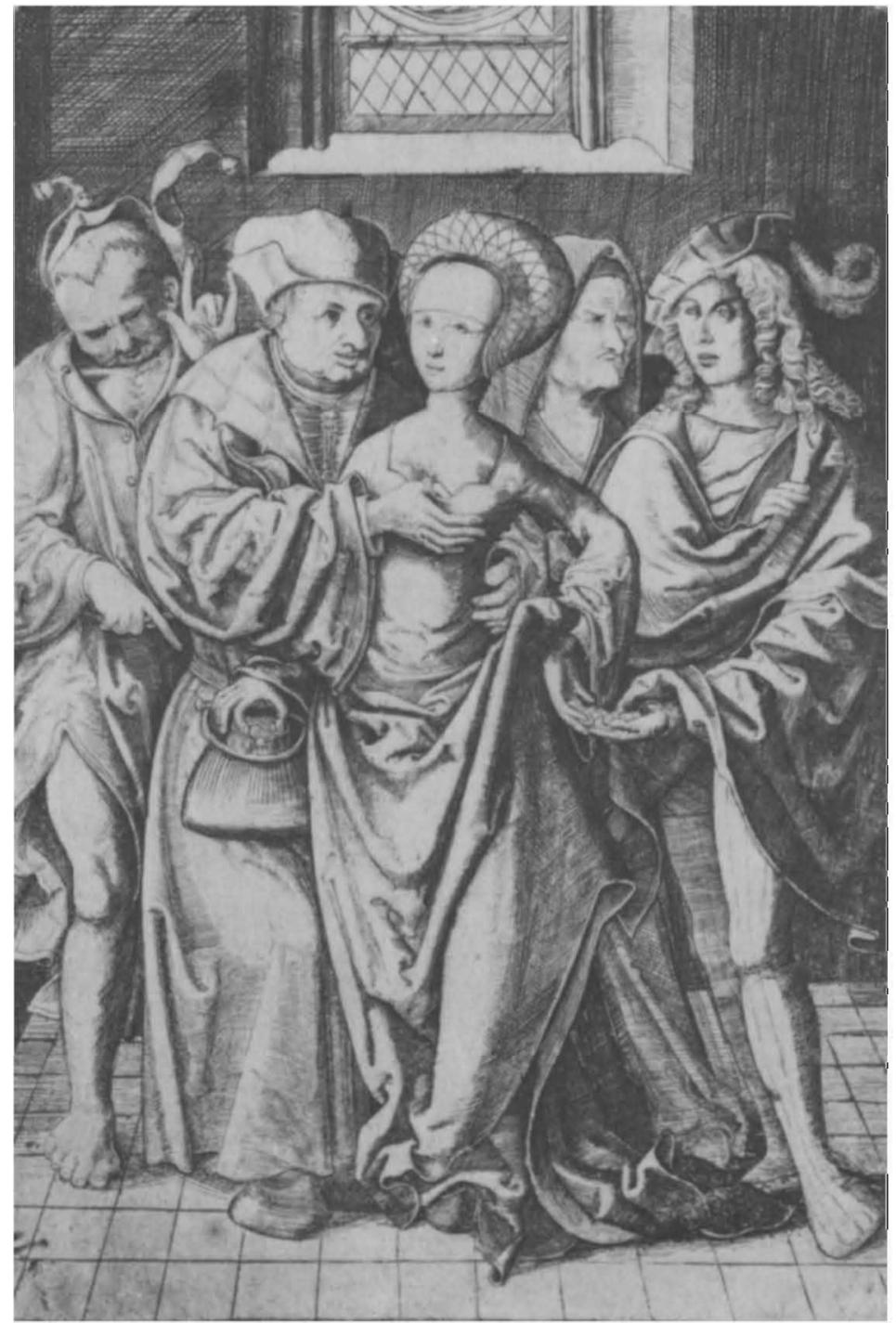

45. Formerly Attributed to the Crayfish Master, Love Triangle with a Fool and Old Woman, (or Two Unequal Couples with a Fool?), engraving, ca. 1520-30 
The "horns" gesture made by the fool indicates that someone is being cuckolded or insulted. In the Dutch language, "making someone a cuckold" is rendered as "placing the horns on someone" ("jemand hoornen opzetten"). ${ }^{175}$ This expression originated from the fanciful belief that cuckolds wore horns on their brows, and "cuckolding"' refers to an earlier practice of growing a castrated cock's spur on the root of the amputated comb where the "horn" often grew to several inches; this idea was known about 1500 in England. ${ }^{176}$ It was also known in Italy, where a Florentine engraving, dating from the last third of the century, The King of the Goats: A Satire on Cuckolds (fig. 46) depicts many horned men. ${ }^{177}$ A young man feebly embraces a nude young woman, and the old man whom they have cuckolded is dubbed as such by a goat, as the old man objects, "I plead guilty, the sin is not mine." 178 A young man in the center states, "He is more a goat than I," 179 probably referring to the old man beside him, one of whose horns another young man saws off. The inscription below, "Whoever is not a goat will become one,"180 appears to be the message of the print.

Whether Italian or German, however, the burden of responsibility seems, in the artists' conceptions, to fall upon the women, for it is the younger partner who dupes the elder, and in most cases women are the

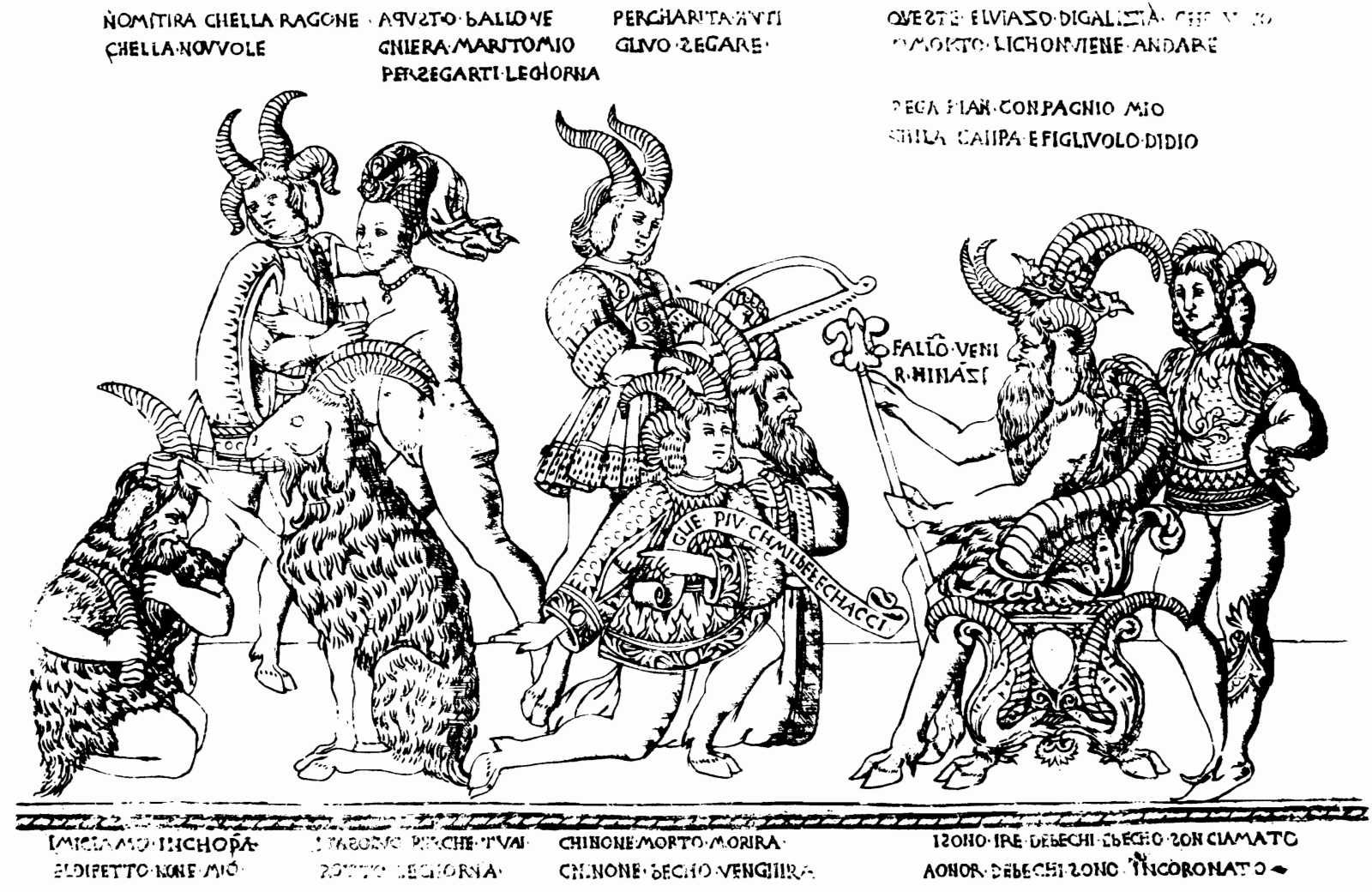

46. Florentine, The King of the Goats: A Satire on Cuckolds, ca. 1470-90, engraving 


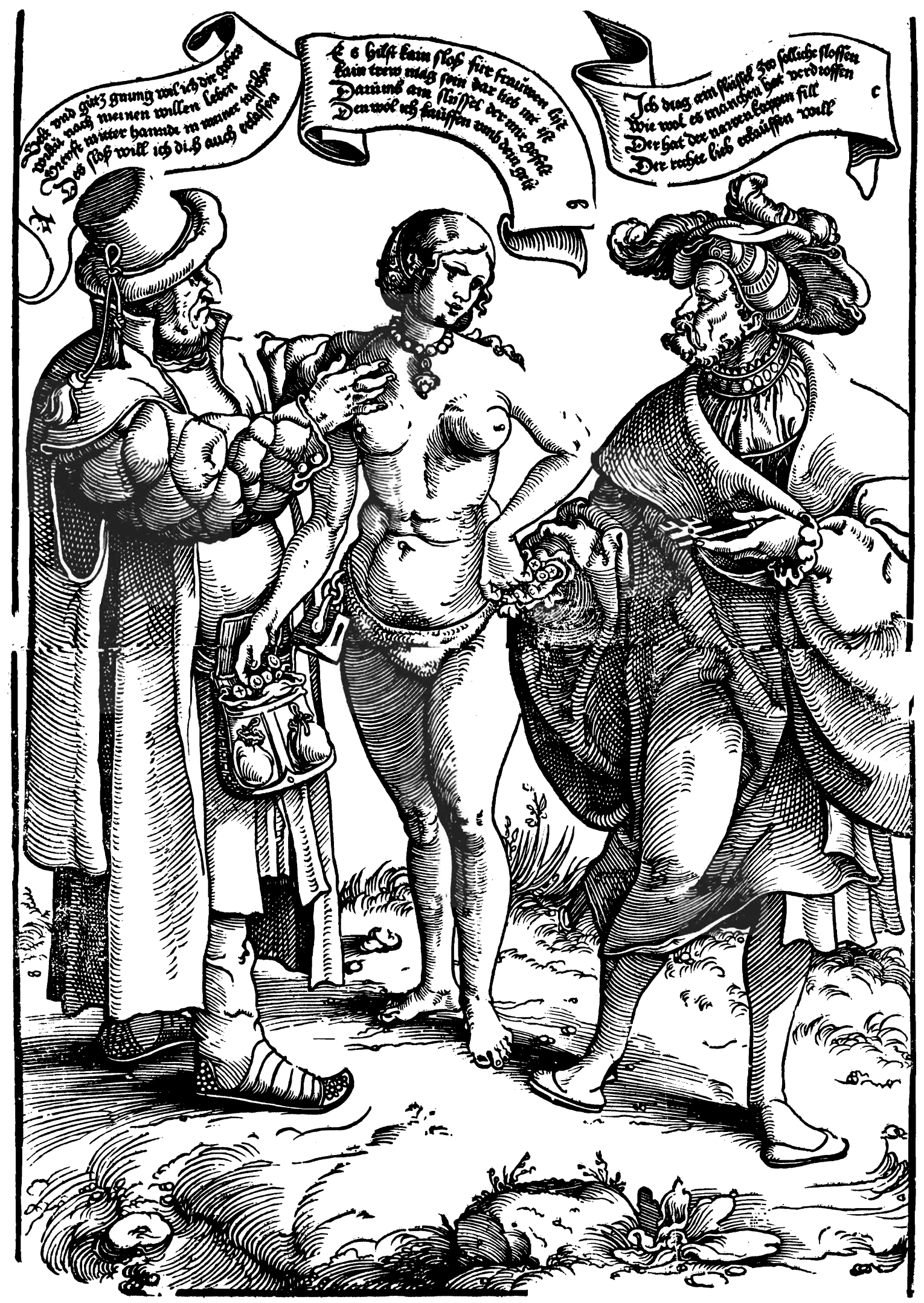

47. Anonymous Nuremberg Artist, Love Triangle with Chasity Belt and Key, ca. 1525-30, woodcut 
young partners. In the etching after Lucas (fig. 43), the power that young women hold over old men-gained by allowing them to fondle their breasts-is indicated by what appears to be a relief sculpture on the bed's headboard, depicting Judith holding the decapitated head of Holofernes, a subject also within the realm of the Power of Women theme. A similar topic, again dealing with the power of women, may have decorated the partiallyincluded glass roundel in the engraving that was formerly attributed to the Crayfish Master (fig. 45).

The folly of an old man who attempts to purchase love is stated outright in a contemporary Nuremberg woodcut of ca. 1525-30 (fig. 47), which has been variously attributed to such Nuremberg artists as Heinrich Vogtherr, Hans Baldung, and Erhard Schön. In this print, known in three variations (figs. 48-50), the basic three-figured Love Triangle composition is retained. As an old man touches his companion's shoulders, she passes coins from his purse to a younger man who holds the key to her chastity belt, and thus to her freedom to indulge her sexuality. The banderoles above record their conversation, which the old man begins by saying:

I will give you money and goods enough

If you will live after my intention

Place your hand in my purse and

I will also release you with this key.

She responds with:

Keys don't help against a woman's lust

For there can be no faith where there is no love

Therefore a key that pleases me

I will buy with your money.

The young man holds out the key, saying:

I carry a key for such matters

As well it many has displeased.

He who fills the fool's cap

Wants to buy true love. ${ }^{181}$

The old man is thus proclaimed a fool for trying to buy his young partner's love and for actually believing that he can keep her content, especially considering the availability of the young man's key, certainly also a euphemism for penis. ${ }^{182}$

Very similar ideas can be found in a chapter from Brant's Das Narrenschiff entitled "Of Guarding Wives"' ("von frowen huetten"): 


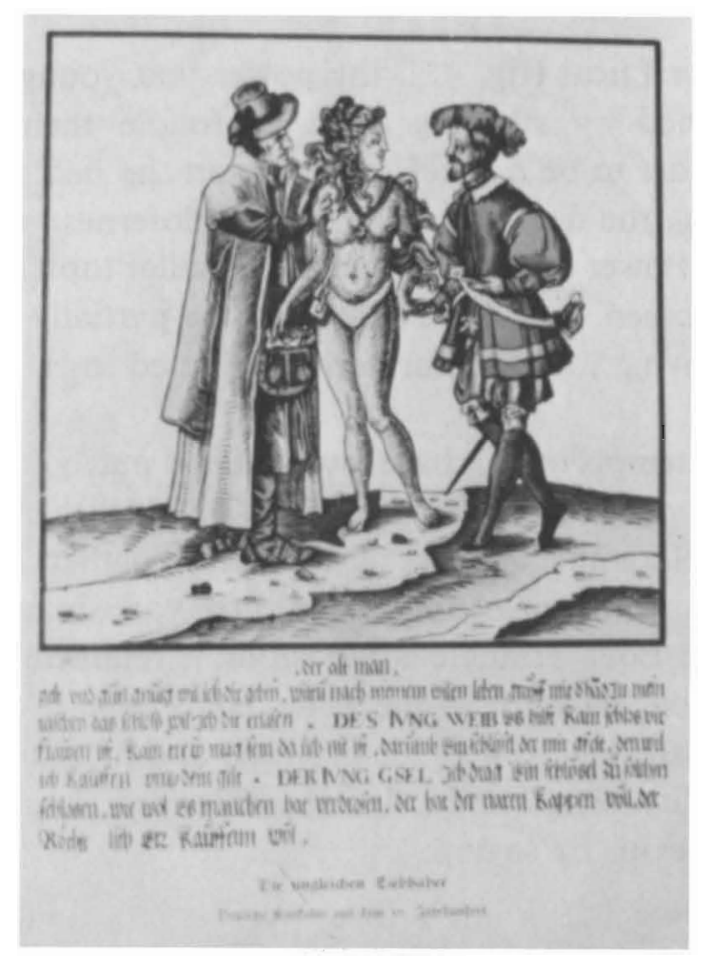

48. Nuremberg, Love Triangle with Chastity Belt and Key, ca. 1525-30. woodcut

49. Erhard Schön, Love Triangle with Chastity Belt and Key, ca. 1525-30, woodcut

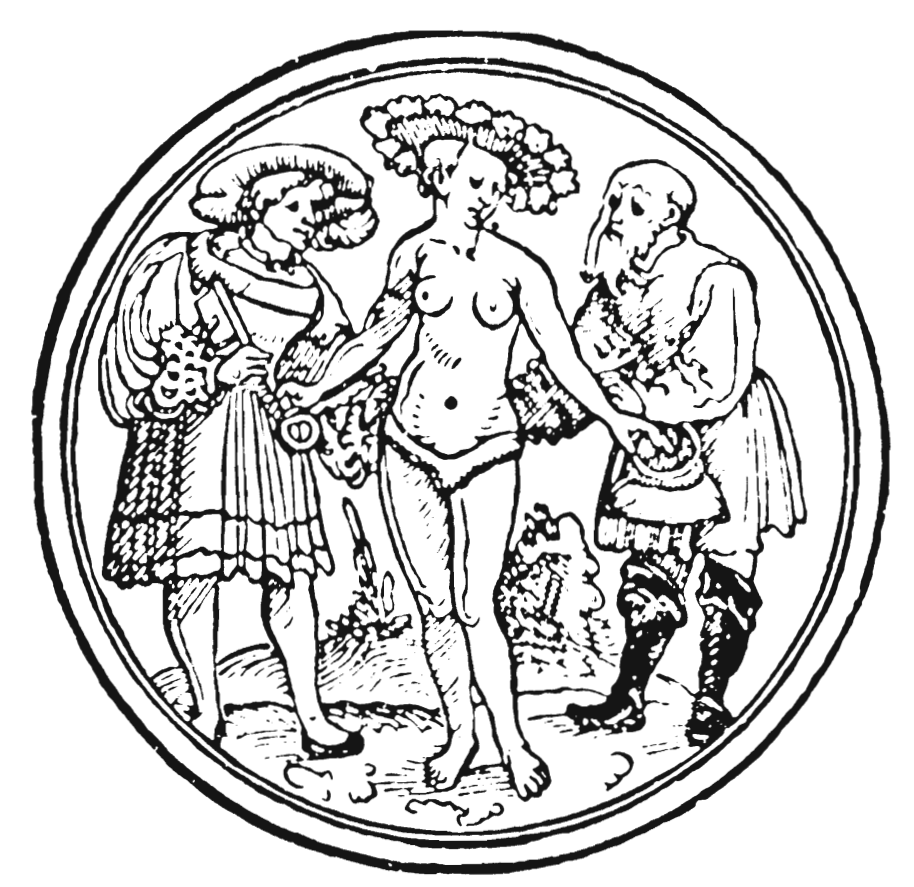


They harvest folly, sheer despair, Who always watch their wives with care, For she who's good will do the right, And she who's bad will sin for spite And manage well to perpetrate Her evil plans against her mate. For e'en a padlock placed before The entrance, be it gate or door, And many guards about the house Can't keep her honest toward her spouse. Danae, held in tower, grieved, And none the less a child conceived.

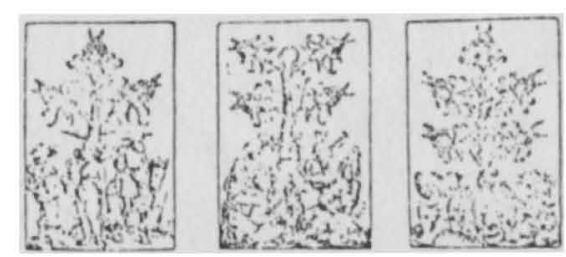

50. Erhard Schön, Love Triangle with Chastity Belt and Key with Old Man on Horseback, ca. 1530 , playing card, woodcut

Here, as in Brant's discussion of the young man who marries an old woman for her money alone (see p.59), folly is associated with the men, though the women are by no means viewed favorably. In the Nuremberg woodcut the woman is characterized as lustful and headstrong, while in Brant's poem she is a shrew. Moreover, in the woodcut the old man is shown up as a fool for believing that even a chastity belt would keep his partner faithful, and Brant's description of the "padlock before/The entrance, be it gate or door," is surprisingly close to the concept behind the chastity belt utilized in the Nuremberg woodcut.

When the chastity belt, which is believed to have been invented in the twelfth century, was introduced into France, some half a dozen jealous husbands purchased belts at a St. Germain fair, according to one report. ${ }^{184}$ But, the story goes, locksmiths soon began to produce duplicate keys that of course nullified the "protection" that they had bought for their wives or, rather, for themselves. The younger man in the Nuremberg woodcut has successfully effected his young companion's freedom by selling her a key that will unlock her chastity belt. (The devices are supposed to have been presented to a wife after the consummation of a marriage, as a token of the couple's mutual faith and understanding!) The early report from France mentioned above, and others from Germany recorded by Brant and Fischart, among others, caution that feminine cunning and wiles will prevail over steel plates and padlocks. ${ }^{185}$ 
in (1) will

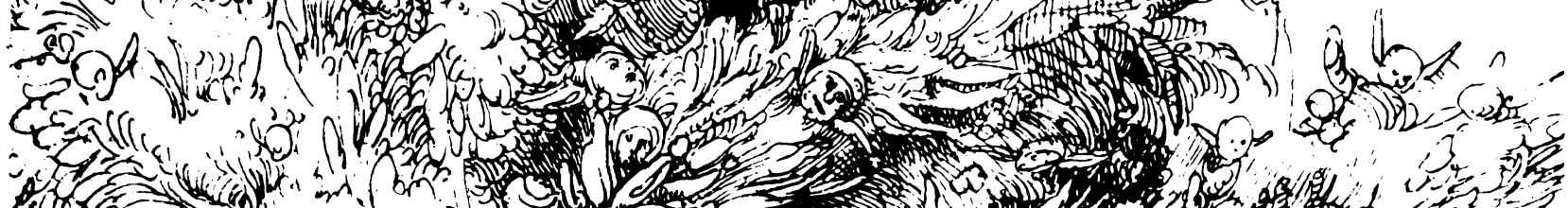

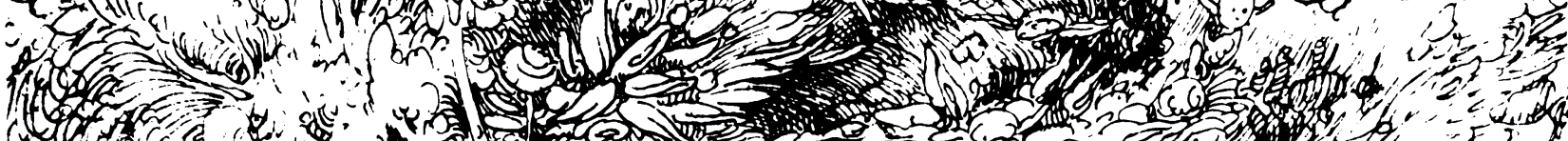
(2)

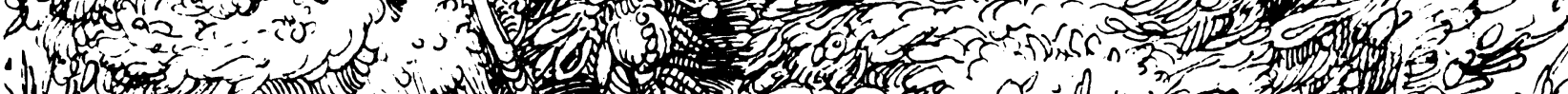
3 1)

(1) 7502020

1 (3)

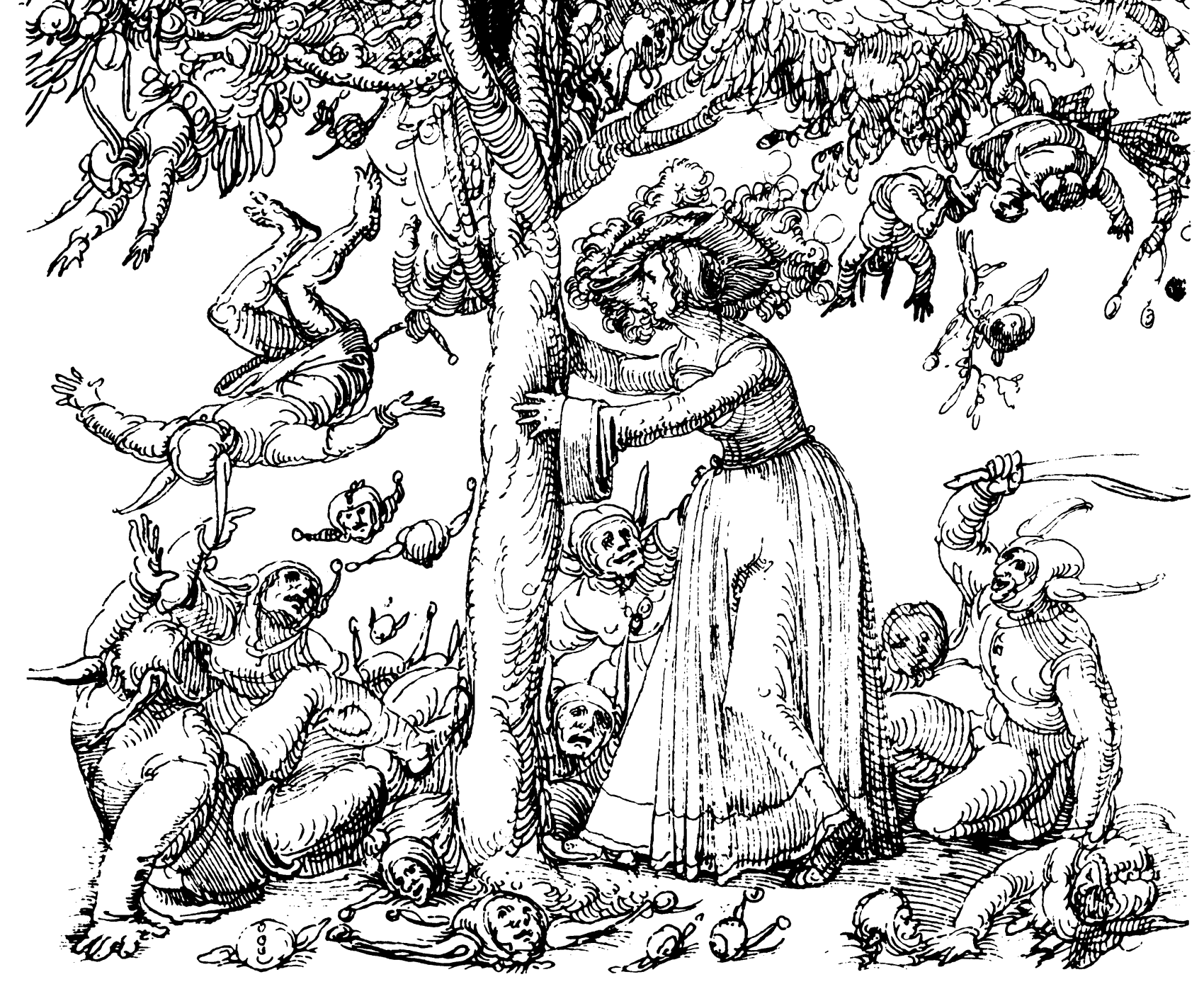

51. Hans Leu or the Petrarca Master (Hans Weiditz), Tree of Fools: Young Woman Shaking Fools from a Tree, ca. 1526, drawing, Veste Coburg, Kunstsammlungen 


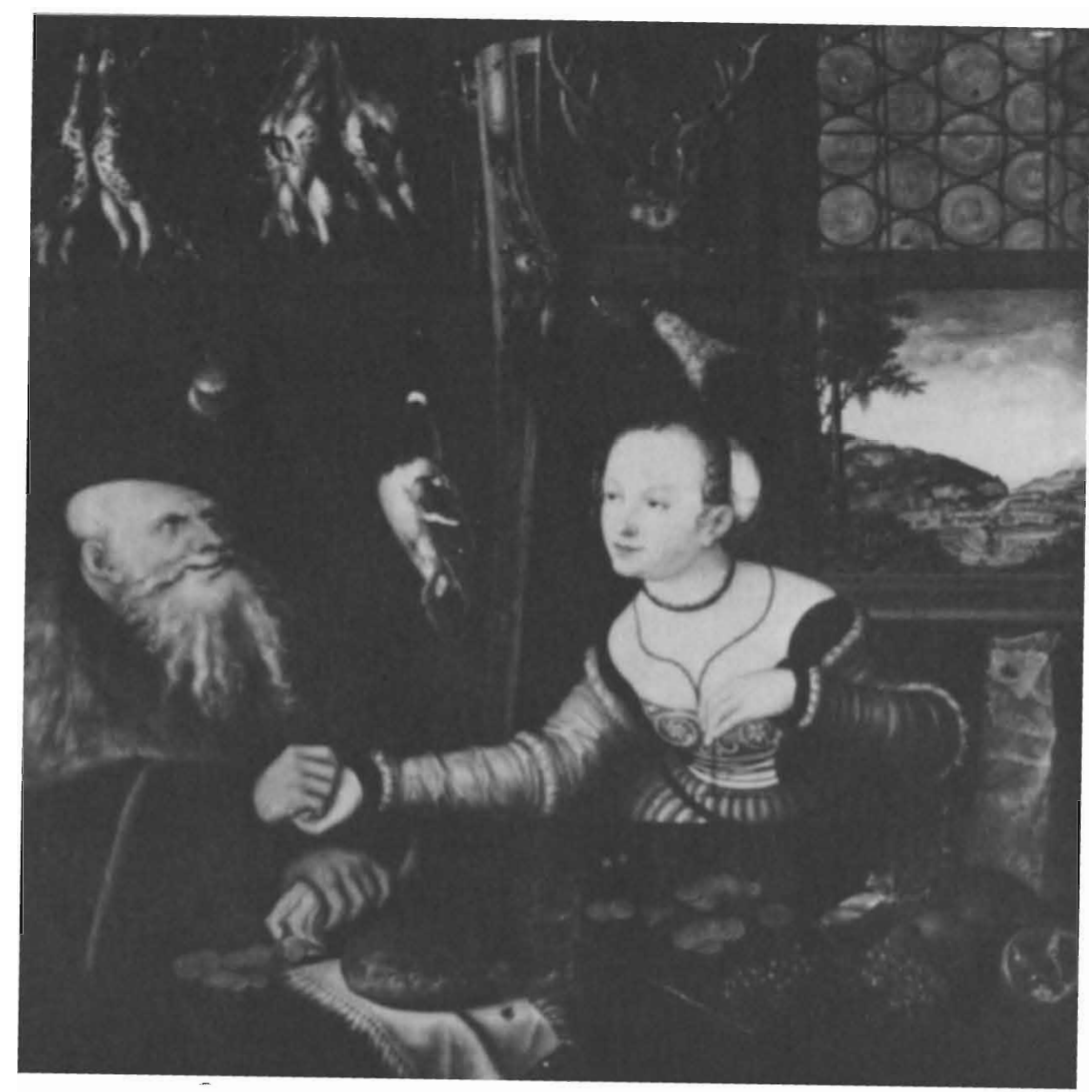

52. Lucas Cranach, The Payment: Old Man Hands Over Money to Young Woman, with Hunting Gear, 1532 panel, Stockholm, National Museum

The chastity belt as depicted in prints like these may have been only a symbol of the futility of man's attempt to tame woman, for the resistance that was called "feminine wiles," "cunning" and "contrary nature" would triumph, especially if other men were willing to help her out of her unpleasant situation. Nevertheless, woman was depicted as the culprit.

Folly continued to be attributed to male lovers in the art of the time. A contemporary drawing of a Tree of Fools (fig. 51), attributed variously to Hans Leu (ca. 1490-1531) or to the Petrarca Master (Hans Weiditz), attests to this. ${ }^{186}$ Dated around 1526, the sheet depicts a well-dressed young woman shaking the trunk of a tree out of which have fallen many fools, and fools' heads and caps. The woman's ability to shake so many fools from the tree, that is, to make men act according to her will, accords with the interpretation of folly discussed above: folly is associated with male passion and women's sexual power over it.

Lucas Cranach's Payment (fig. 52) may also have proclaimed the foolish behavior of an old man, who hands a fistful of gold coins to his 


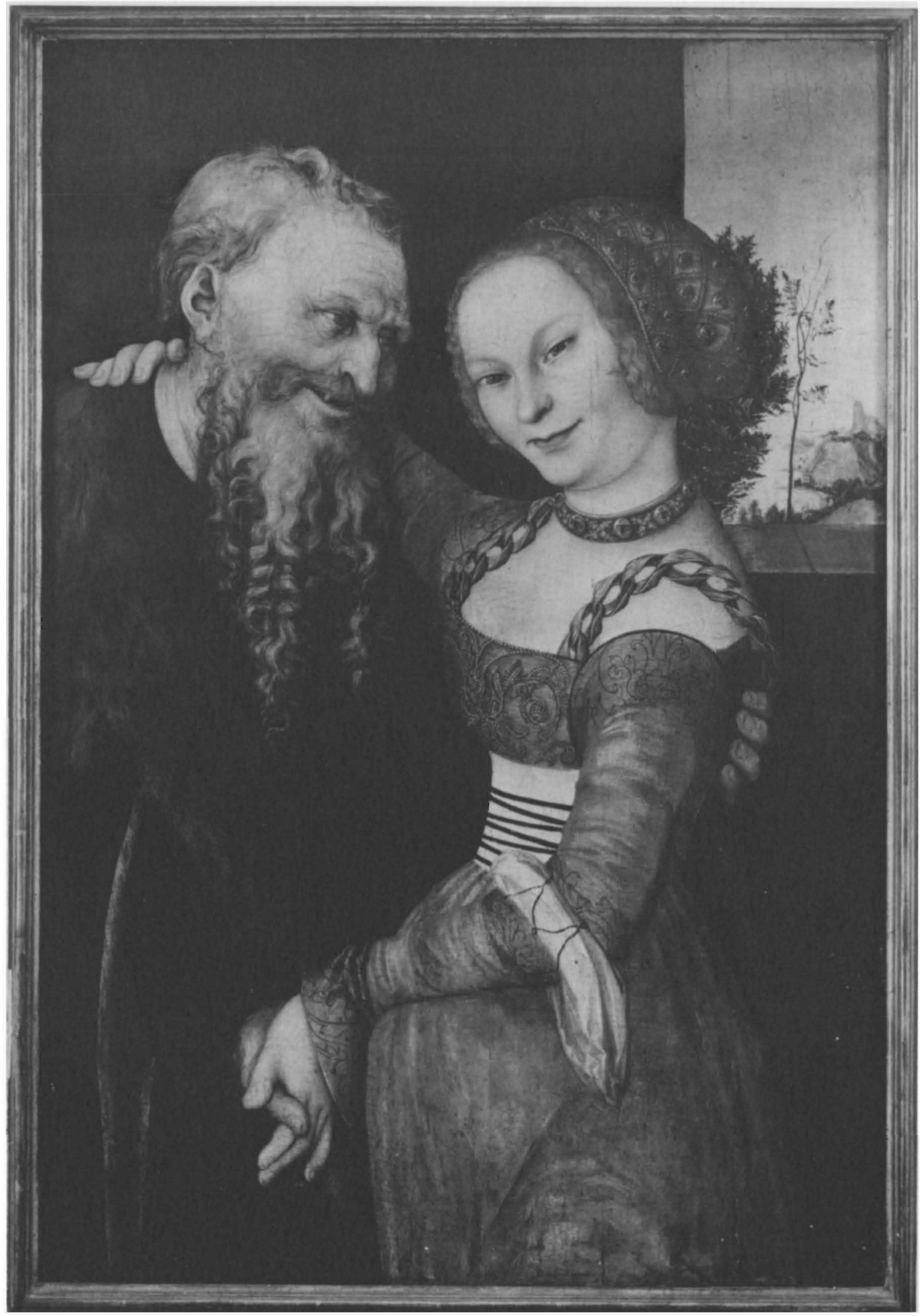

53. Lucas Cranach, Old Man and Young Woman, ca. 1530, panel, Nuremberg Germanisches Nationalmuseum 
young companion. ${ }^{187}$ On the wall behind them hang dead birds, a rifle, a powder horn, stag horns and a watch. The rifle and horns once again suggest the hunt as an allegory of love, or of the pursuit of love, as it was in German literature already before $1300 .^{188}$ On the table can be seen a pomegranate (a symbol of fertility) and a loaf of bread and glass of wine, mentioned above for their associations with lust, ${ }^{189}$ here especially with the old man, who wears a lecherous grin. His young partner, on the other hand, carries on her transaction with businesslike efficiency and appears to ready herself for the weighing of her newly acquired coins. 190

The illicit and therefore foolish nature of this relationship appears to be underscored by the dead birds hanging on the back wall. The obscene use of the word bird ("vogel") in seventeenth-century Dutch has been discussed in an article, and this use of vogel was used even earlier and more widely in northern Europe. ${ }^{191}$ The Grimm brothers have noted an obscene sense for this verb in German, as well as the neutral ones of "teasing, hoaxing or fooling." In addition, and not surprisingly in view of contemporary slang, they list "penis" as a further definition. ${ }^{192}$ It is interesting, in connection with this, to note a particularly ambiguous detail in an Unequal Couple painting by Cranach, known in a version in Nuremberg (fig. 53). ${ }^{193}$ In a variant the woman holds something strongly suggestive of, and identified by Fuchs as, the penis. ${ }^{194}$

It may be significant that the birds in Cranach's Stockholm painting are dead, suggesting that the old man's spirit is willing, but his flesh is not. On the other hand, it may have been unfeasible to include live birds in such an interior scene. Dead birds hanging on the back wall may have been preferable, since they fulfilled the twofold function of referring to the hunt as an allegory of love and denoting the couple's obscene intentions. The goose, placed in the center of the panel, directly over the transaction, probably emphasized its especially lustful nature, for the waterfowl was possibly the most lascivious type of bird. ${ }^{195}$

The tall, chiseled-looking object at the right on the table may be a large piece of cheese, which could have symbolized folly, as it did in both late medieval and Renaissance art. ${ }^{196}$ The representation of folly in a new guise here would expand the visual repertory for folly in Unequal Lovers scenes. As nicely as this would fit, however, the presence of other still-life objects that appear to be nothing more-the grapes, for example-suggests the possibility that the cheese carried no allegorical significance; and the object itself is of questionable identification. 


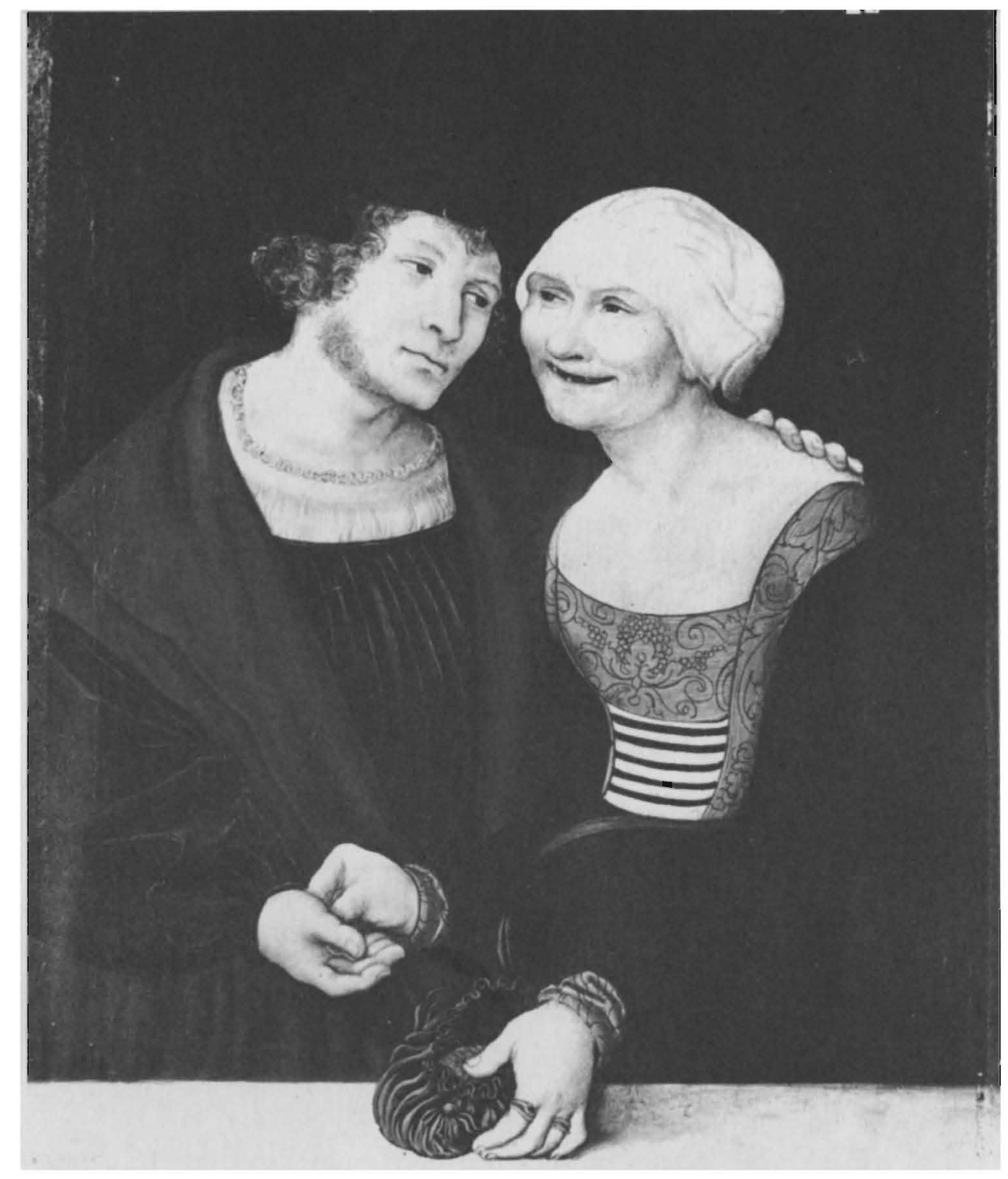

54. Lucas Cranach, Old Woman and Young Man, ca. 1520-22, Budapest, Szépmüvészeti Múzeum

\section{Costume}

The costume of around 1500 as a rule reflected the social standing of the person wearing it. A brief investigation of the types of costume worn by unequal lovers should therefore help to clarify the classes to which the lovers belonged as well as to ascertain what, if any, dynamics of class were involved. 
55. Hans von

Kulmbach, Old Man and Young Woman, ca. 1510-1530, panel Private Collection.

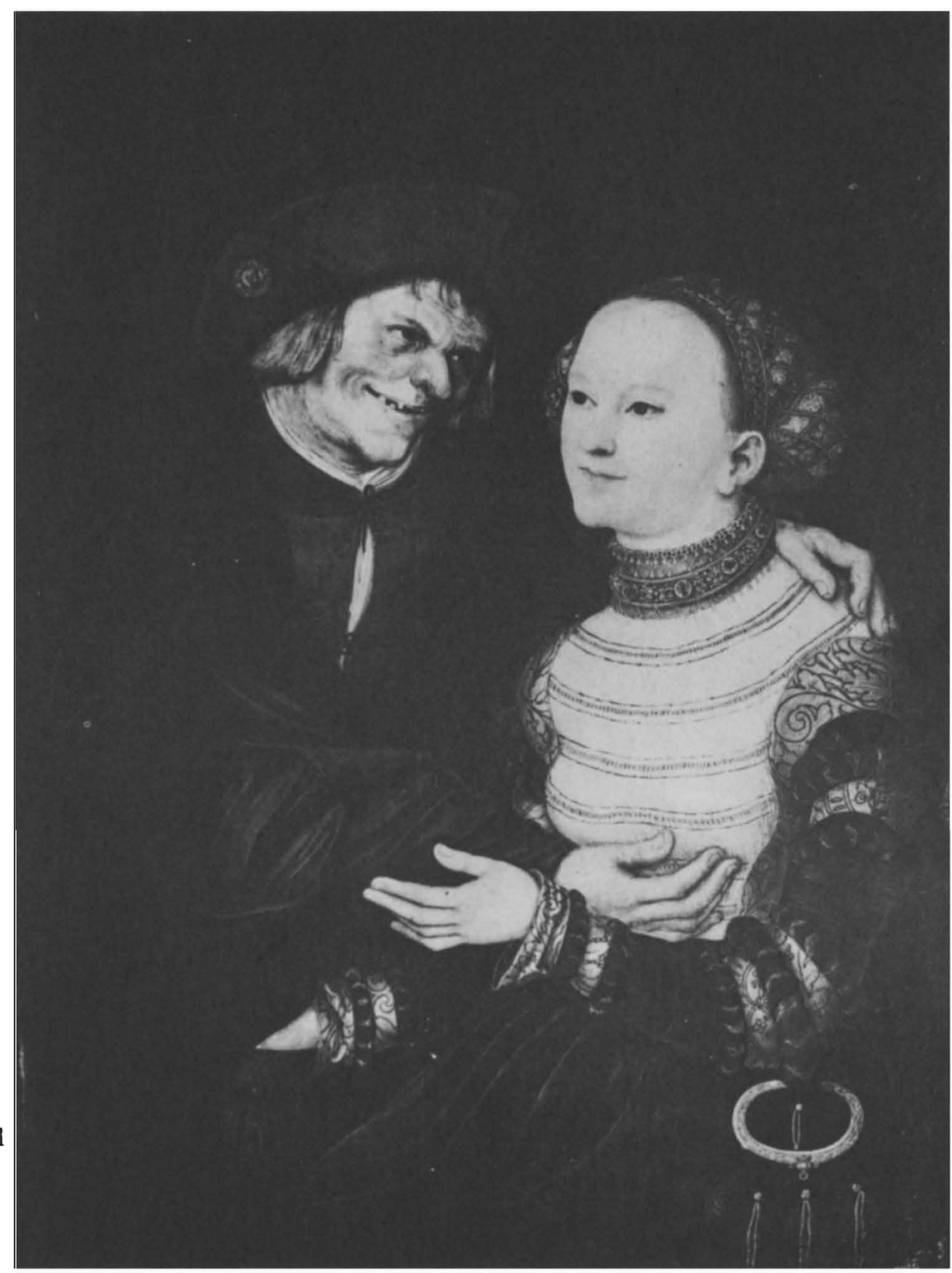

Most of the individuals in Unequal Lovers scenes dress in a manner befitting the wealthy (see, for example, figs. 14, 36, 54 and 55). Women's dress in general is more decorated and more richly detailed than the clothing of men of similar standing, but in most cases male and female partners are dressed in a manner suggesting that both share the same social standing. In seven cases, however, the man is dressed considerably more plainly. Men, on the other hand, are better dressed in only two works (figs. 56 and 57). 


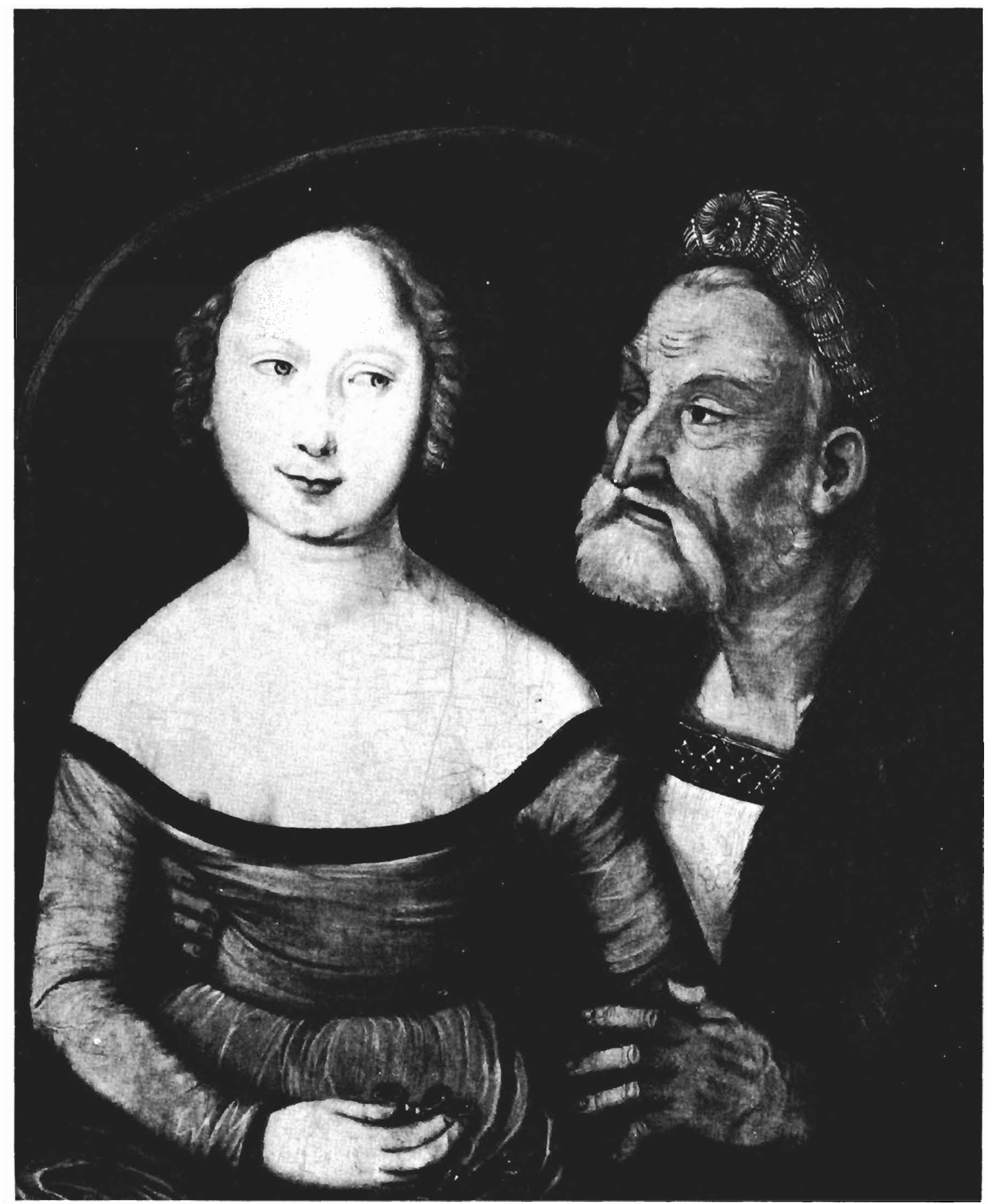

56. Hans Baldung. Old Man and Young Woman, 1527, panel, Liverpool, Walker Art Gallery 


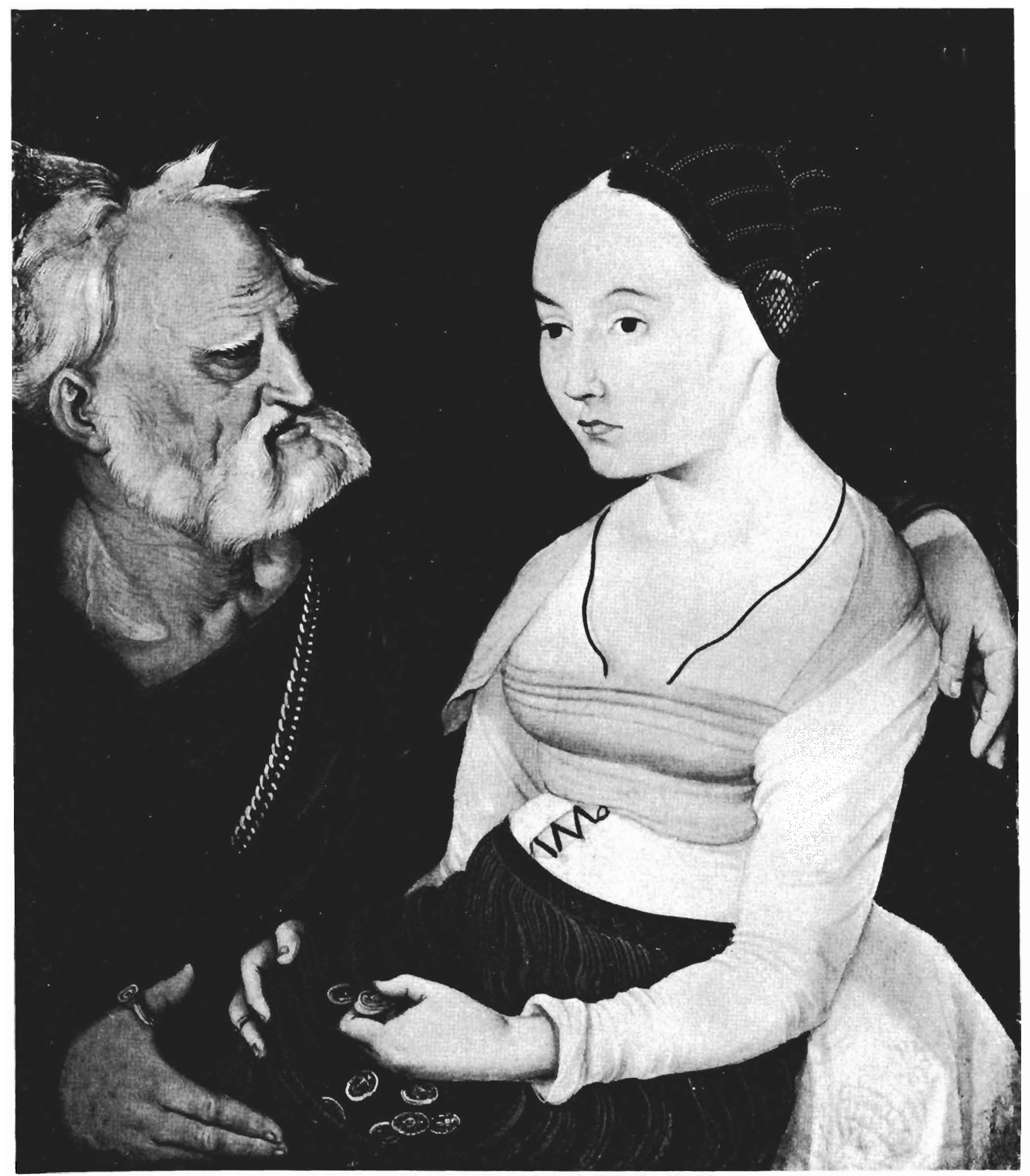

57. Hans Baldung, Old Man and Young Woman, 1528, panel, Karlsruhe, Kunsthalle 


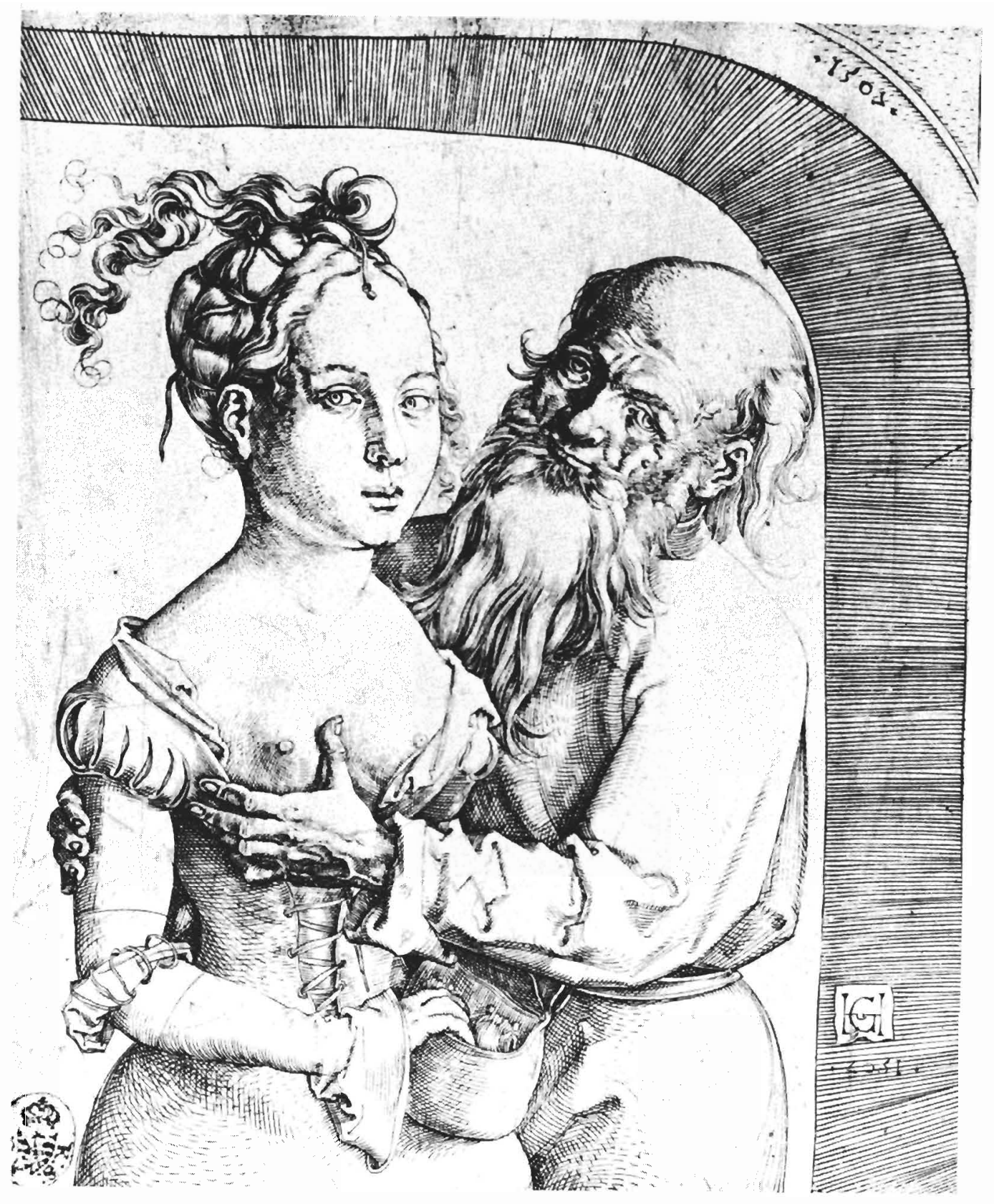

58. Hans Baldung, Old Man and Young Woman, 1507, engraving

The seven cases (figs. 6 and 58-63) in which an old man is more plainly dressed than his younger partner might suggest at first glance that he is either marrying or consorting with a woman above him in class. But frills and finery do not a lady make. Prostitutes were probably affected somewhat differently by the general rule that costume must reflect the social class of its wearer, and it is quite possible that a lower-class man like Strigel's (fig. 63) ${ }^{197}$ is dealing with a prostitute. Marriage, however, need not be ruled out. A man of lower social standing, pleased and proud to marry a woman of a higher class, might have been willing to pay more dearly for the privilege. In the drawing attributed to Jörg Schweiger (fig. 61), the woman 
raises her skirts, a gesture that was associated with marriage or engagement. $^{198}$ Thus Strigel's couple may be prostitute and client, or an unequally-married couple.

Where men dress in finer clothes than their women companions (as in figs. 56 and 57), the implication is that money has given the man the power to buy the companionship of a young woman, be she prostitute or potential wife.

The disparity in dress between the old man, on the one hand, and the younger man and woman, on the other, is immediately apparent in Graf's Love Triangle (fig. 6), where costume reflects a common sympathy between the young people. Costume is similarly used in other Love Triangles by Erhard Schön and Niklaus Manuel (figs. 44 and 62). Similar dress does not necessarily imply similar social standing, especially if the woman is a well-dressed prostitute. Courtesans certainly used ostentatious dress to attract customers and Lucas Cranach's numerous Unequal Couples and

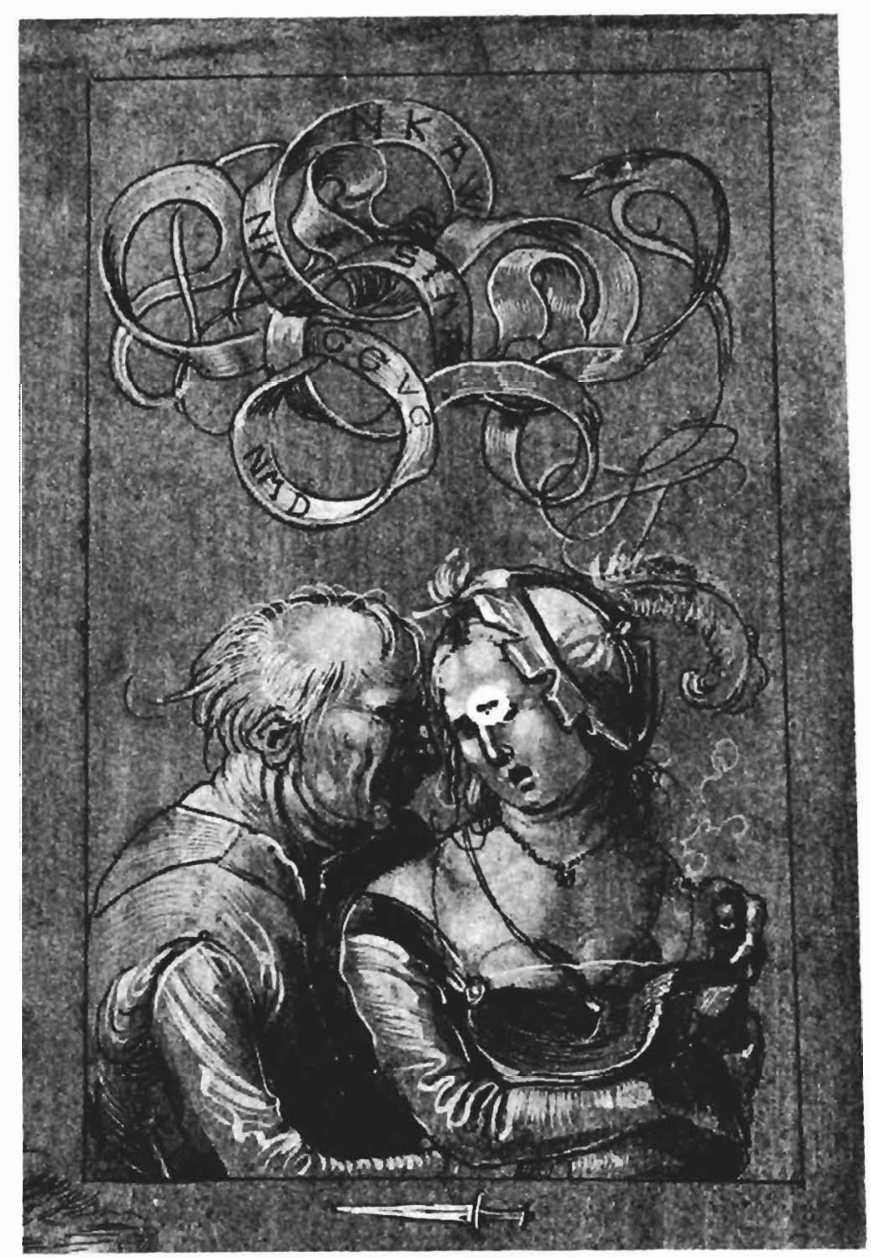

59. Niklaus Manuel, Old Man and Young Woman, ca. 1517 , chiaroscuro drawing, Basel, Kupferstichkabinett, Kunstmuseum 


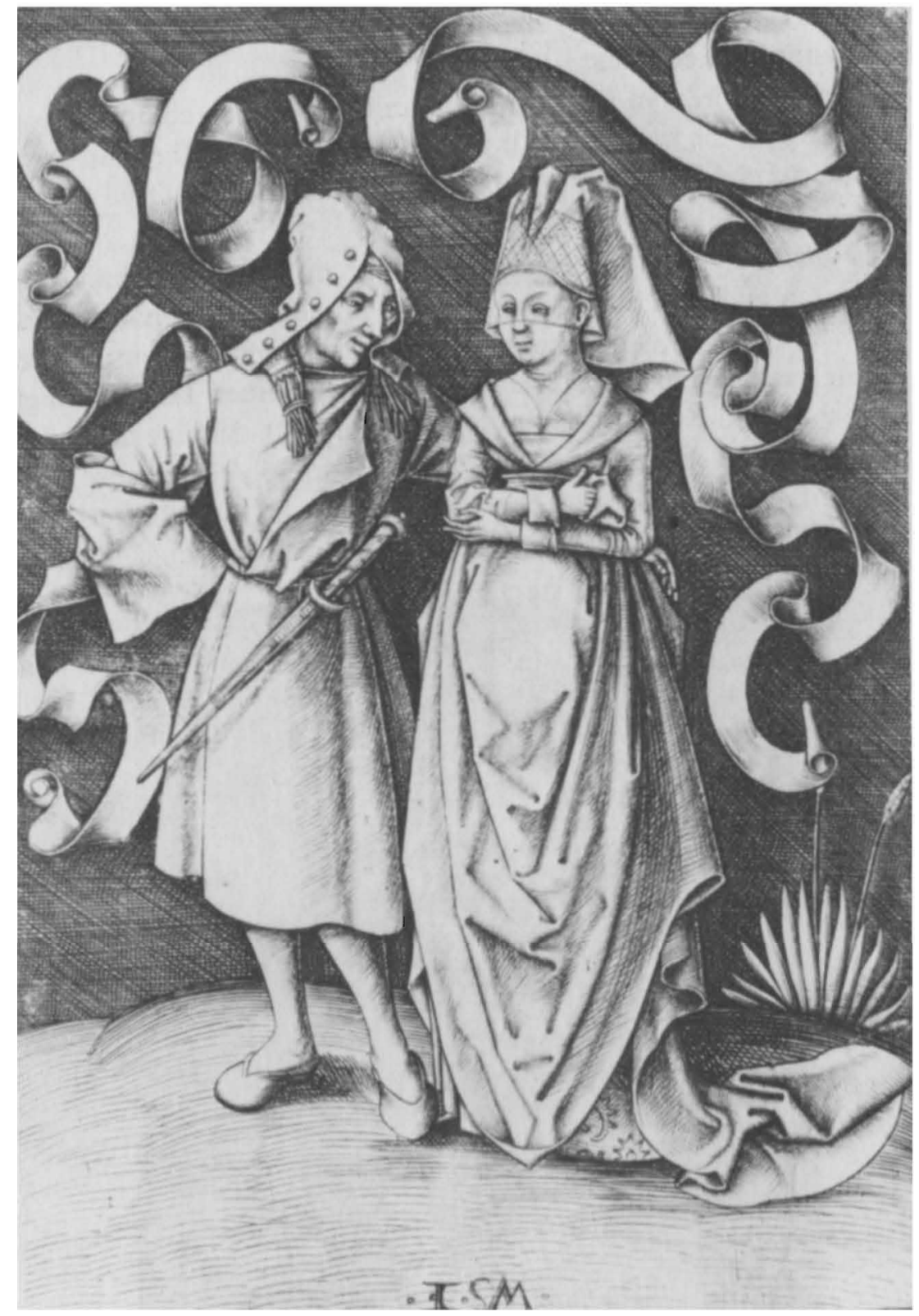

60. Israhel van Meckenem, Old Man with Younger Woman, 1497 or earlier, engraving

earlier examples by Dürer and the Housebook Master (figs. 1 and 14) may illustrate this point. In the latter's drypoint of the Old Man and a Young Woman (fig. 14), the woman wears a dress very similar to the one worn in Dürer's illustration of Brant's chapter "Of Amours"' (fig. 21). That chapter has been described as bringing to mind 
the mala mulier from the German moral encyclopedia of around the early fifteenth century.... [and] the biblical seductress in the attire of a harlot whose effect on her victims, the infatuated apes, is as mortal as that of the basilisk. ${ }^{199}$

Costumes in representations of Unequal Lovers generally help us to interpret these works. Yet in some cases, where man and woman are dressed equally well, costume aids little in establishing whether the woman is a professional, or merely a venal wife. Whether the woman is a wife, a courtesan or a prostitute, the manner in which the pair is dressed often adds yet another dimension to the differences that exist between lovers of dissimilar ages.

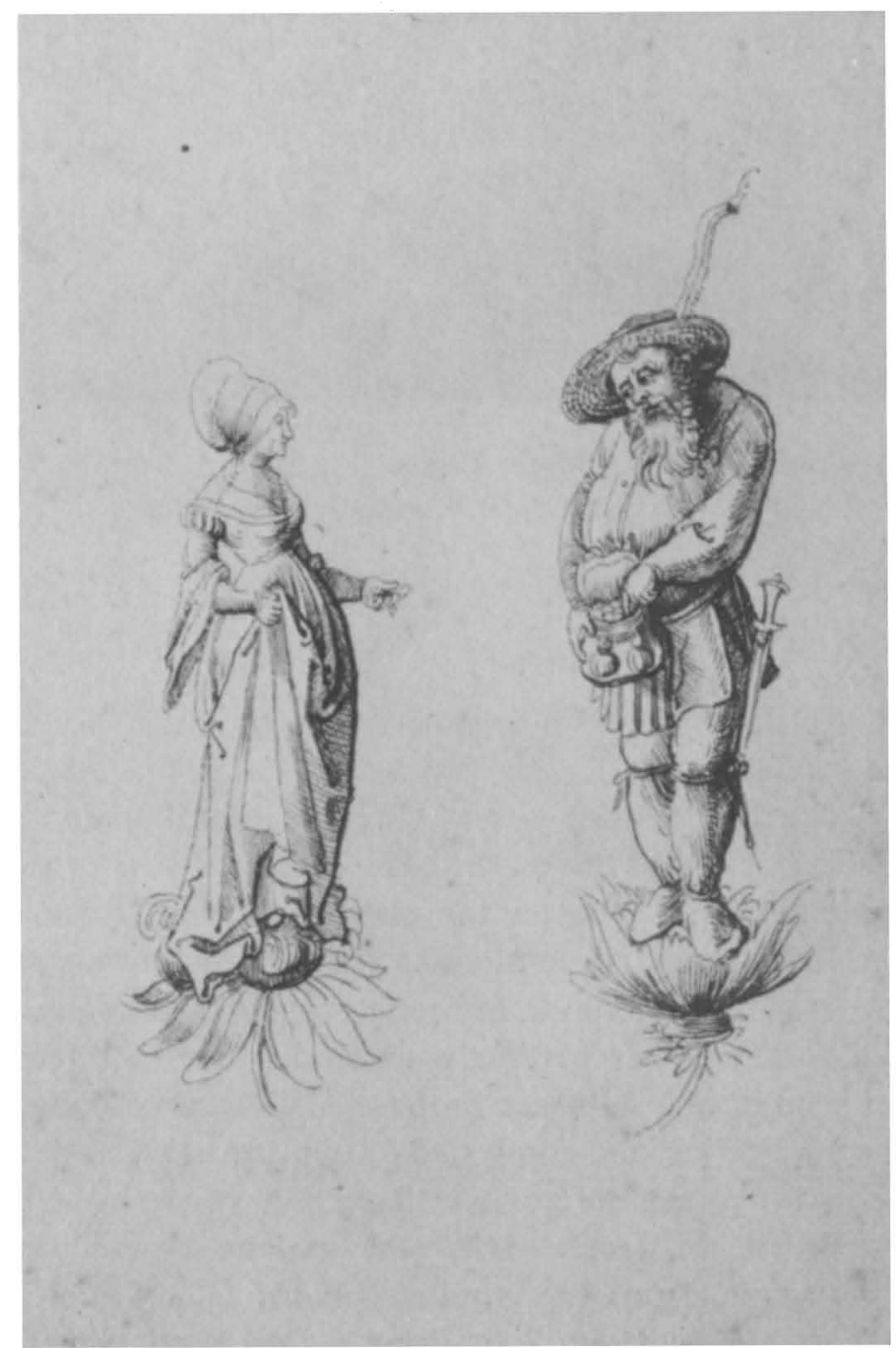

61. Attributed to Jörg Schweiger, Old Man and Young Woman, ca. 1510, drawing, Basel, Kupferstichkabinett, Kunstmuseum 


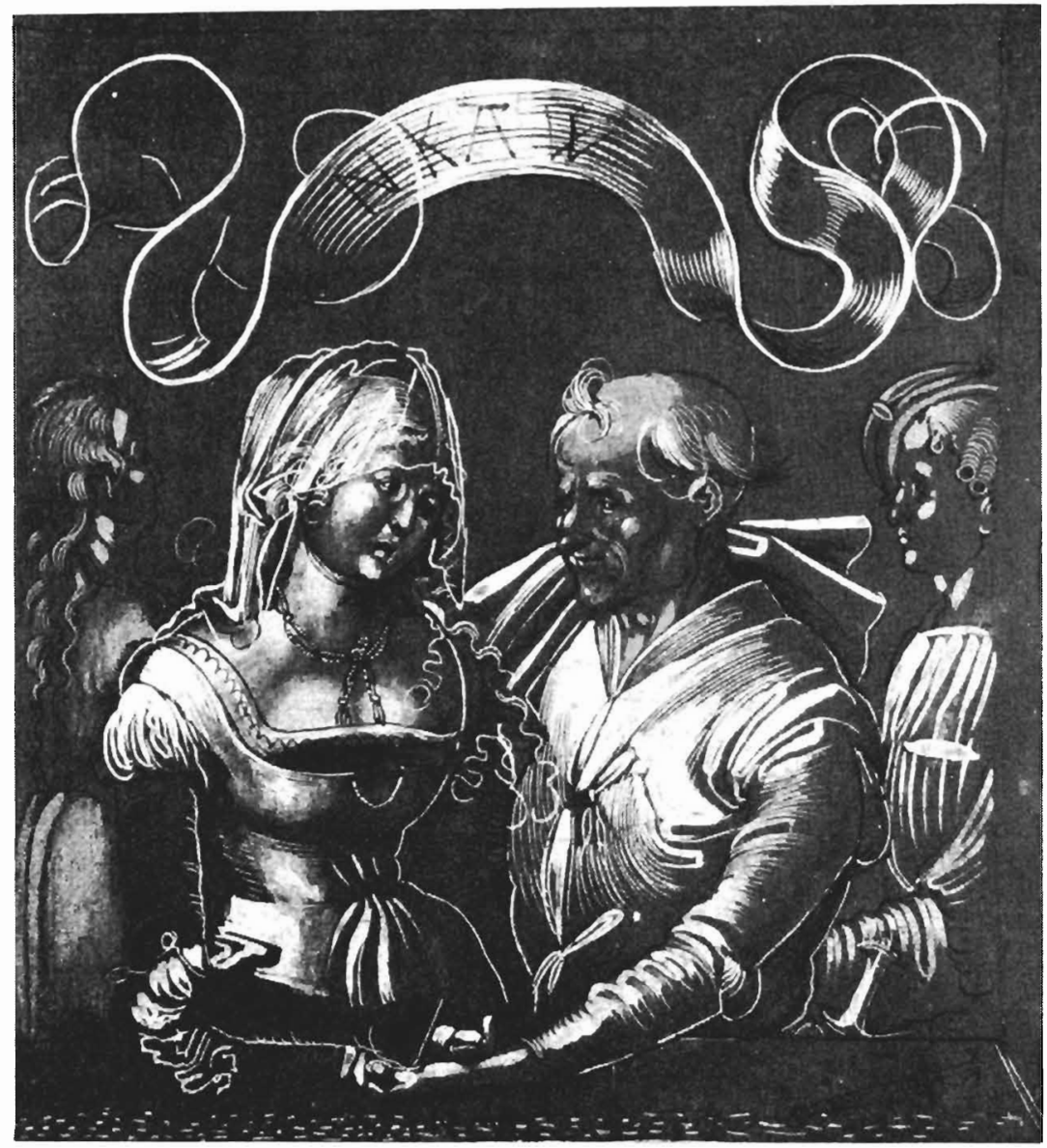

62. Niklaus Manuel, Love Triangle with Old??) Woman, ca. 1517, chiaroscuro drawing, Basel, Kupferstichkabinett, Kunstmuseum

Garlands

Only five representations-four Unequal Couples and one Love Triangle-include garlands worn on the head, almost always by the younger partner. Despite variations in type, the garlands generally seem to denote betrothal. Garlands not only decorated the virgin bride, but were also worn by the groom. ${ }^{200}$ The Housebook Master's drypoint Old Man and Young Woman (fig. 14) depicts her wearing a garland, which has recently been described as a symbol of a marriage promise. ${ }^{201}$ The artist may even have meant it to be a mock garland composed of old dried twigs or straw, or a garland somewhere between the two, which might have carried some satirical connotations. ${ }^{202}$ The interpretation of the garland as the token of an engagement or marriage promise is more convincing in Dürer's woodcut illustrating the unequal couple from Brant's Das Narrenschiff (fig. 32). There the young man is crowned with a garland whose flowers are not easily identifiable, owing perhaps to the still unperfected woodcut medium. The 


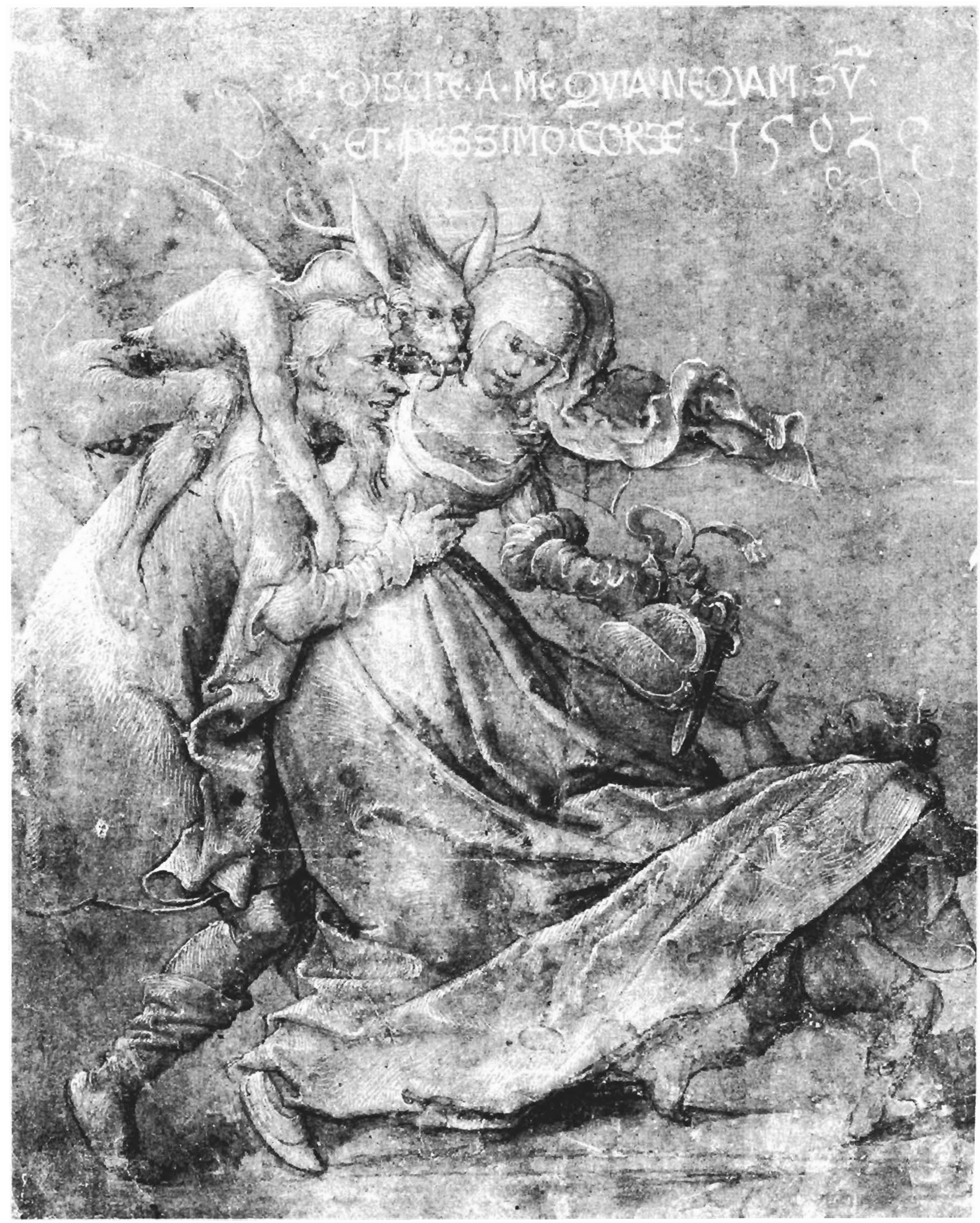

63. Bernhard Strigel, Unequal Couple: Old Man and Young Woman with Demon and Putto Accomplices, 1502, chiaroscuro drawing, Berlin, Kupferstichkabinett, Staalich Museum Preussischer Kulturbestif 


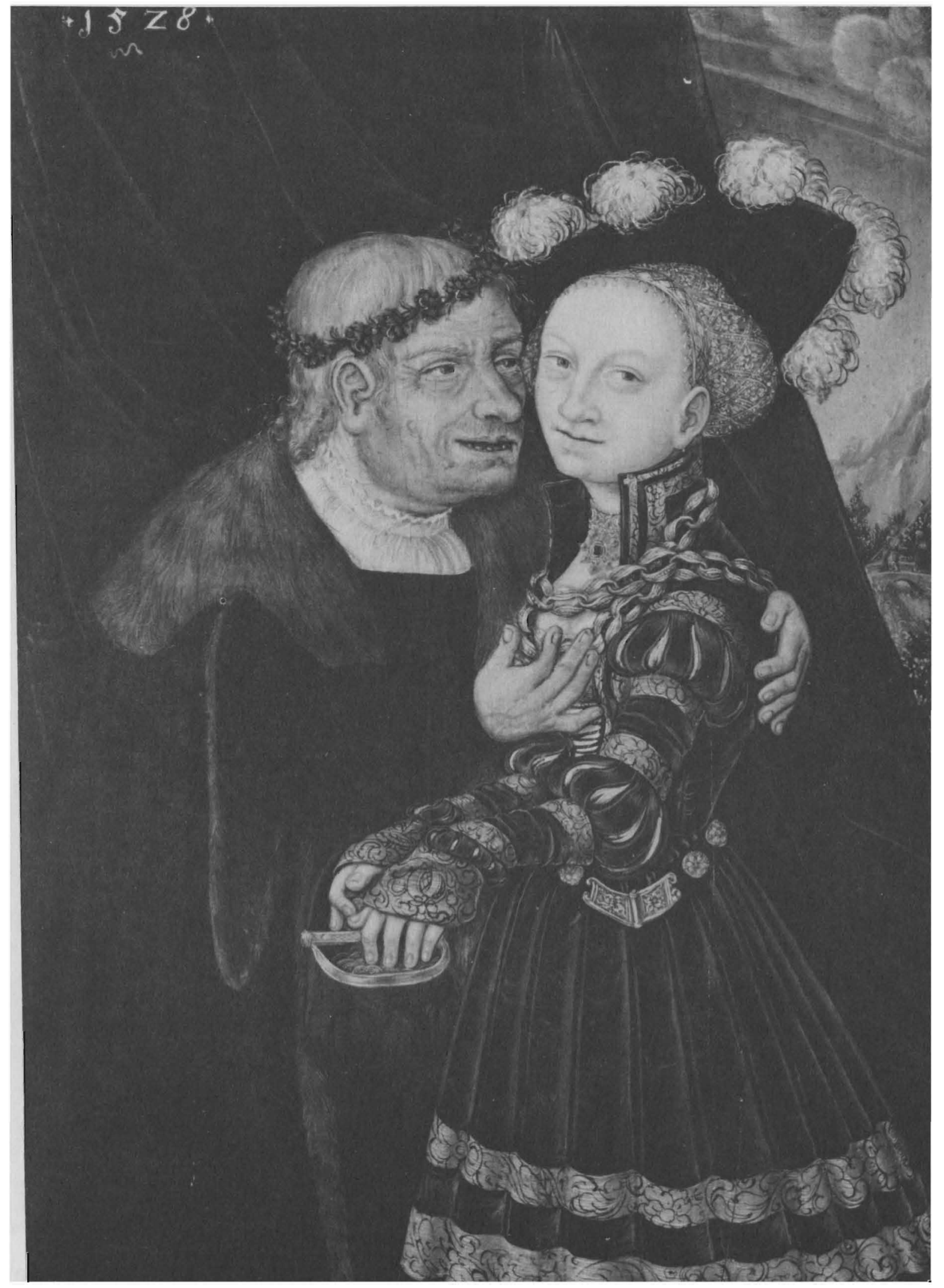

64. Wolfgang Krodel, Old Man and Young Woman, 1528, oil on board, New York, Ira Spanierman Gallery 
connection between garland and betrothal is attested to by the chapter title ("Of Marrying for the Sake of Goods") and its verse, which proclaim the venal intentions of the youth who marries an old woman. ${ }^{203}$

Marriage may also have been connoted in Graf's Love Triangle (fig. 6), in which a young woman wears a crown-the most splendid version of the garland-according to a custom that goes back to antiquity. ${ }^{204}$ The young woman's crown appears to be made of gold, pearls and flowers, in keeping with the contemporary description of the bridal crown in Thomas Murner's Geuchmatt, where it is described as composed of costly materials. ${ }^{205}$

Wolfgang Krodel's Old Man and Young Woman (fig. 64) includes a repulsive old man wearing a garland of red carnations, a flower often used at this time in scenes of the Virgin, of lovers, or in portraits, as an attribute of marriage or betrothal, whether potted, held, or worn. Especially pertinent to this discussion is the inclusion of the carnation garland in fifteenth- and early sixteenth-century German betrothal portraits, for it was customary at betrothals for the bride to place a garland of carnations on her bridegroom's head. ${ }^{206}$ The carnation, it was believed, had the power to ward off evil forces that bridal couples were especially susceptible to, ${ }^{207}$ just as an engagement or wedding ring was believed to hinder evil spirits and illness demons from invading the body. ${ }^{208}$

The connotations of the garland were not, however, always as innocuous as this, and it may have had overtones that still elude us today. A woodcut that probably dates from the third decade of the sixteenth century (fig. 65) depicts a nude (possibly Fortuna) standing on an orb, wearing only

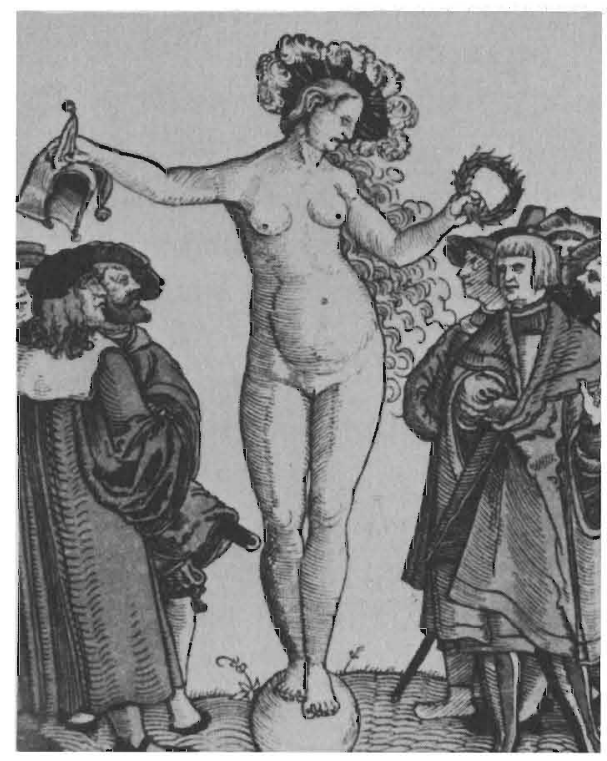

65. Nuremberg, Fortunal?) Presenting Men with Fool's Cap and Ciarland, ca. 1520-1530, woodcut 
a plumed hat, her long hair trailing down her back. To the group of men on the left she hands a fool's cap and to those on the right a garland of what may be laurel, the traditional symbol of victory and virtue. ${ }^{209}$ Even though the men at the front of each of these groups are, respectively, young and beardless, and older and bearded-which suggests that the older are fools and the younger the victors (possibly the better lovers) - the remaining men in each group do not support this dichotomy of age and type. How this woman has decided who are the fools and who the victors is difficult to establish, if the garland is viewed in this manner. If the garland represents virtue, the artist may have intended to contrast foolish luxury and virtue; yet the group as a whole does not support this interpretation either. The association of the fool with luxury may be appropriate here, and is in keeping with a Schwank or sung poem by Hans Sachs of 1566 entitled "Der kram der narrenkappen" ("The Shop of Fools' Caps"). ${ }^{210}$ In the shop, men who have engaged in illicit love are sold fools' caps like the one handed over to the left in the woodcut. ${ }^{211}$

The young woman in Jacopo de' Barbari's Unequal Couple (fig. 66) wears a garland of laurel or bay over her long, flowing hair. ${ }^{212}$ The combination of the garland, her pose-leaning on her hand-and the generally sober tone of the painting suggest the melancholic temperament and call to mind Dürer's Melencolia I. ${ }^{213}$ In that print of 1514 , one of Dürer's master engravings, the winged figure stares out in a similar manner, while resting her head on one hand in the typical melancholic pose. Her garland, however, is composed of water parsley and watercress, two naturally "wet" plants, which grow in water, and were believed to counteract the drying nature of this temperament. ${ }^{214}$ Jacopo's Unequal Couple is unique among Unequal Lovers in its generally somber mood, which makes an interpretation of the garland very difficult here. The painting seems to stress melancholy, and the marriage garland points to the stultifying effects of marriages between old and young, mocking the "happy couple" with a traditional laurel crown of victory.

Long, Unbound Hair

The custom that long, unbound hair is more appropriate to young women or girls than to older women is indeed an old one, and is still current today. The association of long, unbound hair and youth or maidenhood goes back many thousands of years. ${ }^{215}$ Around 1500, the practice seems still to have been current, for married women in Germany had to wear their hair covered with a "Frauenbinde," a veil or bonnet; a more severe tradition existed in ancient Prussia, where the wife's hair was cut off before she entered the bridal bed, at which time other women presented her with a garland and a white cloth, believed to have been a cap or hood. The woman was to wear this until she bore a son. ${ }^{216}$ 


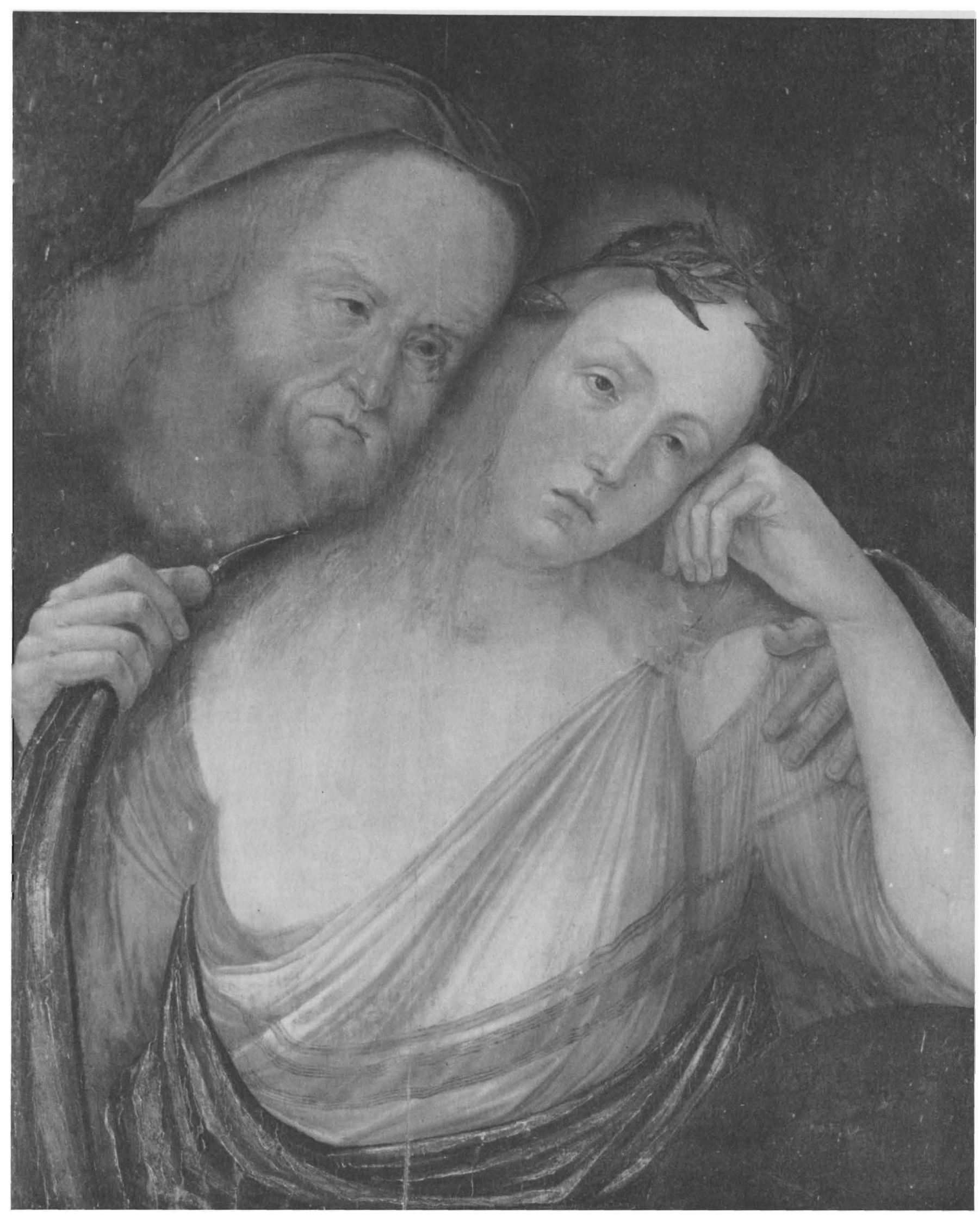

66. Jacopo de' Barbari, Old Man and Young Woman, panel, Philadelphia Museum of Art, Jahn G. Johnson Collection 


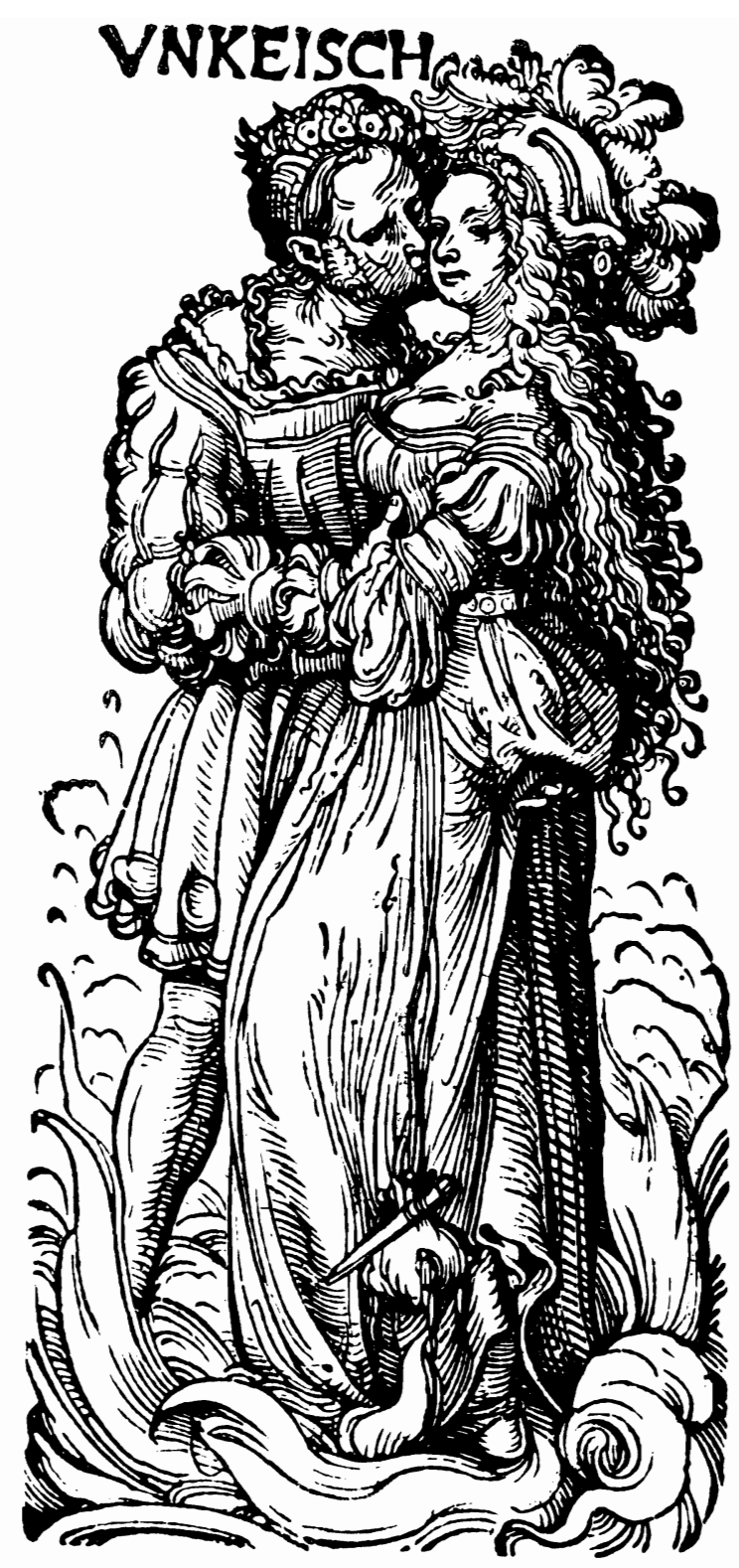

67. Hans Burgkmair, Unkeuschheit (“Lechery”), ca. 1510, woodcut

Few women around 1500, and probably none of the self-respecting married women depicted in art, wear their hair down or loose. Exceptions can be found in allegorical and biblical figures, especially the Virgin and female saints, who, however, are almost always represented as young 
women. It seems that in representations of lay women of the late Middle Ages loose hair was equated with freedom, even sexual freedom.

Literary and artistic sources corroborate the association of long, loose hair with the single state, or even with illicit sex. Erasmus equates long hair with the former as he describes a woman dressed in her finery, and wearing her hair down "exactly as though I'm about to be married." 217 Hans Burgkmair illustrated the latter idea in his 1510 woodcut (fig. 67) of the vice of lechery, Unkeuschheit (inscribed "VNKEISCH"). There, a voluptuous woman sports a low-cut dress, as do many of the women in Burgkmair's two series of virtues and vices. ${ }^{218}$ Appropriately, the décolletage seems to be more exaggerated in this illustration, as is her hair-an ostentatious display of thick, cascading curls topped by a lavishly plumed hat-than in any of the thirteen other prints in these series. The suggestive placement of the man's hand bunching the woman's skirt at her backside, and the inscription, make the improper behavior clear to the viewer.

Long hair was even earlier associated with what were described as feminine characteristics or flaws. What was viewed as the changeable and feeble nature of women is represented in an Austrian manuscript dating from the last quarter of the fifteenth century (fig. 68), in which two young women with long unbound hair illustrate the chapter on maidens in Hugo von Trimberg's Der Renner, completed before $1200 .^{219}$ The author speaks of maidens' "long hair, short wit and changeability of mood," and the artist depicts the northern custom of loose long hair for maidens. The association is made between that hairstyle and woman's amorous desires; for the author comments that maidens' changeable moods are exemplified by their finding different types of men attractive at different times.

How should long, loose hair be explained in representations of women in Unequal Lovers? As with the showy dress, one cannot be sure whether these are single women who have involved themselves in semipermanent immoral relationships, or whether they are prostitutes using their long hair to entice customers. As a matter of fact, in representations of the Unequal Couples theme the number of women who are wearing their hair in this manner is small. They are found in Jacopo's Unequal Couple panel (fig. 66) and Holbein's drawing (fig. 36); and in Graf's woodcut (fig. 6) and Manuel's chiaroscuro drawing (fig. 62), both of which illustrate Love Triangles. Cranach also included young women with long, loose hair in some of his Unequal Couples and expanded compositions (Handlist nos. 24, 31 and 82 ).

Jacopo's panel may associate marriages of unequal couples with the melancholic temperament; Graf's woodcut depicts a single woman engaged or promised in marriage, or involved in promiscuous relations like Manuel's young woman. Cranach's women are either unmarried or prostitutes, while Holbein's woman is very young and appears to be in it for the fun! 


\section{Evil and Vanitas}

The majority of Unequal Lovers are depicted in a fairly humorous, lighthearted manner. A small number, however, include inscriptions and details that point to death as the ultimate reward for such lovers. The presence of symbols of evil in these works suggests that some patrons and members of the Unequal Lovers' audience took a more serious and moralizing view. On the other hand, for some, the inclusion of death and evil may have been an excuse or justification for owning art that was obviously lascivious; by this inclusion the works became socially acceptable.

The first extant example of the presence of evil in an Unequal Couple dates from 1492, when the Antichrist appears as a demon with pendulous breasts. Father and daughter will commit incest because of the work of the devil, according to the inscription at the top of the woodcut: "Here sits the father of the Antichrist who courts his own daughter in lust/She yields to his advances and receives the Antichrist from her own father." 220 Strigel's Unequal Couple of 1502 (fig. 63) also includes a demon who is perched atop the shoulders of the couple and thus encourages their evil activities together-as in Manuel's later pen drawing (fig. 37). Strigel's point of view is clearly moralizing, as indicated by the inscription at the top of his drawing: "Learn from me because I am wicked and of evil heart."221 But the inscription need not be viewed only as didactic: one wonders whether the wicked nature of this relationship would not have delighted and amused. The new, independent medium of chiaroscuro drawing may have had its audience in such circles as the humanists, for their education made them more receptive to innovation than the more traditional-minded lower and middle classes; the Latin inscription is a further corroboration. It is noteworthy that this chiaroscuro drawing bears the only inscription in this study that was written in Latin.

Graf's woodcut of ca. 1512, Love Triangle with Symbols of Pleasure and Transience (fig. 6), illustrates the dangers of thinking only of the delights of this world without considering one's ultimate fate. Graf's lovers, the still-life details on the table, the inscription, and the memento mori below all support such an interpretation. The backgammon board and dice cup, the cards and lute were all viewed as sinful diversions, and the assortment of fruit on the platter would have been noteworthy and appealing for its sumptuousness and for its erotic overtones. The covered goblet, typical of contemporary German work in this medium, may also have been viewed as an exces:, a utilitarian object whose beauty far exceeded necessity. The skull and bone below underscore the inscription set forth in the banderoles on either side: "Consider the end that is my warning, when all things end in death." The empty banderoles above, as well as the comma that follows the inscription below, suggests that the inscription would 


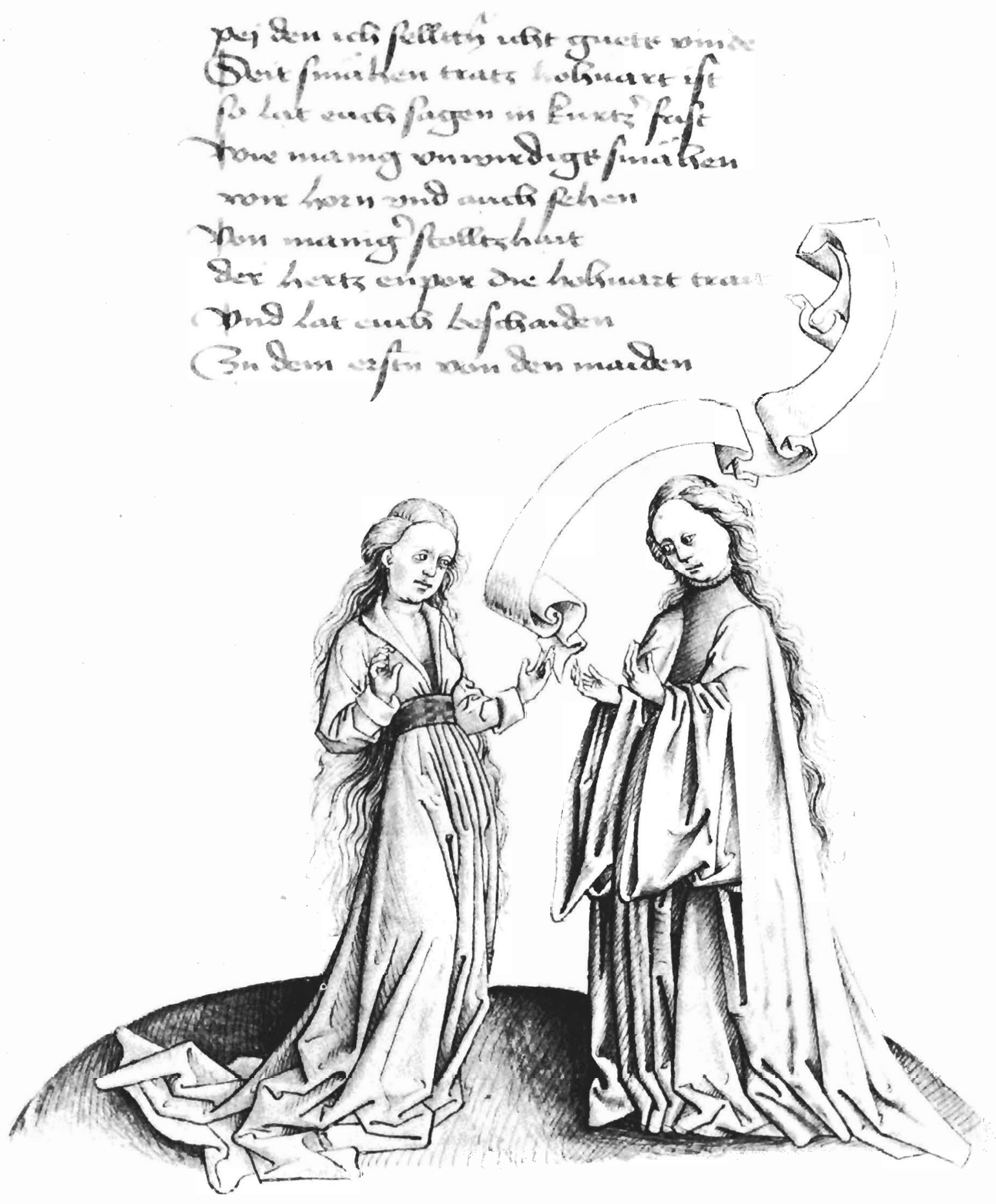

68. Austrian, Women with Long Hair and Short Wits, illumination from Der Renner ca. 1475-1500, New York, Pierpont Morgan Library 
continue at the top with words from the old man: "Birds of a feather flock together, I therefore want to get in the middle [i.e., between the two young lovers].", 222

The memento mori and vanitas aspects of this print are also seen in two other extant representations of Unequal Lovers. In a Love Triangle etched after Lucas van Leyden (fig. 43), skull and bone have grown into a life-size skeleton holding shovel and hourglass, the latter referring to the passage of time as death approaches. The serious and didactic tone suggested by the ominous Grim Reaper is offset by the figure of the grinning fool who makes the "horns" sign of the cuckold.

Lucas Cranach's Payment in Stockholm (fig. 52) likewise includes the element of vanitas though it is reduced to an even less obvious position than in Graf's woodcut or in the etching after Lucas van Leyden. Only the watch hanging from the back wall warns against the delights of this world.

The inclusion of the still-life and genre-like details seen in the Graf and Lucas compositions attests to the newly rising interest in genre associated with contemporary Netherlandish art, especially with the oeuvre of Lucas van Leyden. But the newness of genre-like symbols should not deceive the reader into believing that a lack of vocabulary accounted for the sparse distribution of such threatening or warning motifs, for since ca. 1494 German Unequal Lovers had available for the depiction of evil, the demon, a device known widely in late medieval art. That the artists depicting Unequal Lovers for the most part chose not to include demons or ominous inscriptions, and that they included some of the new genre vocabulary in only a few instances, points in general to an interest in this lascivious, titillating theme more for its own sake than for its moralizing and didactic potential. 


\section{Chapter 5}

\section{Conclusion and Interpretation}

\section{Power of Women, Courtly Love, and Contemporary Society}

The Unequal Lovers theme arose in the graphic arts in the fifteenth century. It was partly a reflection of the already-existing satires on love, the venal, and the Power of Women, themes which were included in literature and art well before 1450, by which time they had begun to be popularized in prints. These satiric themes referred not only to contemporary social tendencies (including the emergence of capitalism and the formation of a newly-rich class of burghers), but also to the overthrow of the late medieval concept of courtly love.

When Master E.S. for example, in the 1450s and 1460s depicted men as fools, labelling them as such by their costumes and situating them in love gardens, the effect was clearly a turning away from the courtly ideal of love, in which the lady was idealized by a gentleman who obtained her love through service. With the waning of courtly love, woman was now cast in the older, more negative mold of temptress and controller of love affairs, ${ }^{223}$ a role for which she was considered well suited as the daughter of Eve, who, like her foremother, was easily tempted to lust. ${ }^{224}$ However, one common factor is noteworthy. In both the French concept of courtly love and the northern satiric Power of Women, it is woman who is supposed to control the relationship by bending man to her will. Woman is placed on a pedestal and idealized in courtly love; in the satires (Power of Women), she is brought solidly down to earth where she can be resented for a power which is viewed as too strong, even as out of control. In either case woman is viewed as the more powerful partner. The German reaction to courtly love consisted of a rejection of the elevation of the lady, but posited a sexual dynamic in which woman still had the upper hand.

Of course, the idea of courtly love had been popular in Germany as well as in France. ${ }^{225}$ But the emergence, in Germany, of the satiric Power of Women theme in opposition to its aristocratic predecessor may have had a great deal to do with the increasing importance of money rather than land as 


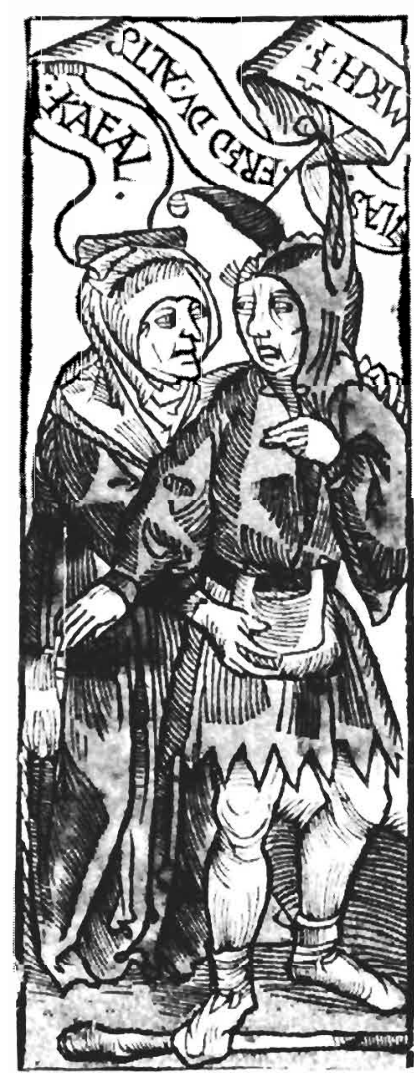

68a. Anonymous German Artist, Old Woman Contemplating a Fool's Purse, third quarter of the fifteenth century, woodcut the measure of wealth. To an extent, the satiric treatment of love coincides with the death-throes of feudalism. Old values were being questioned, the medieval hierarchies examined and found newly inadequate, and the modern state was being born.

In an early fifteenth-century Rhenish tapestry in Regensburg (fig. 69), Minne, the personification of Love, must choose between a noble gentleman, who symbolizes the aristocratic and courtly tradition, and a more humbly-dressed man with money sacks slung over his shoulder, an embodiment of the newly rising bourgeois class produced by German capitalism. ${ }^{26}$ Another contemporary Rhenish tapestry (fig. 20) also foreshadows the graphic satires on love which were to come: a young woman ties an old man and a young man to the fence that encloses the court of Frau Minne. ${ }^{227}$ This tapestry illustrates the already well-known concept of Love as an enslaver of men of all ages. In particular, it points to the idea that women have the power to reduce interested men to slaves or fools, an idea seen as early as the thirteenth and fourteenth centuries in depictions on Minnekästchen (small ornamental boxes which served as love tokens), on capitals, and in frescoes of Aristotle and Phyllis or Samson and Delilah. ${ }^{228}$

A woodcut pasted into a fifteenth-century manuscript represents an old woman fingering a fool's suggestively-placed money bag. "Leave me in peace, you old parasite," he complains to the woman. In another inscription, he informs us: "I am called Henry and fool/The whole world teases me now," a statement suggesting that bargains like his were widely acknowledged, if widely disapproved of. (See left.) 229

Did women in real life have so much power over their love affairs? If women could select a desirable husband or lover as easily as late medieval literature suggests, how can we reconcile this with the fact that women outnumbered and outlived men, a condition that would point to the opposite situation? In reality even noblewomen had difficulty finding suitable husbands, and as a result, sought refuge in religious houses, as reported, for example, in 1354 by Louis de Mâle, Count of Flanders. ${ }^{230}$

In the early Middle Ages, possibly because of the practice of female infanticide, by all accounts men outnumbered women. At the time of the marriage, men compensated the families of their brides with money. But in the late Middle Ages, the tables were turned, and in Northern Europe it was the family of the bride that was now responsible for presenting a dowry, implying that women must have outnumbered men. ${ }^{231}$ This is exactly the case: statistics from the middle of the fifteenth century show a significant imbalance in population by gender. Nuremberg in 1449 had 1,168 burgher women for every 1,000 men (and a total population of about 20,000). When servants were included, the number of women to 1,000 men rose to 1,207 . The ratio in Basel in 1454 was approximately the same-1,000 men to 1,246 women over fourteen years of age. Moreover, the proportion of women to men in general rose with every decade of age. Even though more boys than girls are reported to have been born (which in itself suggests the continued practice of female infanticide), boys 
died sooner. By the ages of seventeen or eighteen, the numbers of males and females had approximately equalized. After thirty, women began the ascent in population that continued until the ratio went as high as two women for every man in the oldest age bracket, probably around fifty, when there were 1,400 to 2,000 women for every 1,000 men. ${ }^{232}$ The greater rate of male mortality at the time has been attributed to the fact that town merchants were armed, and that men's lifestyles were more immoderate than women's, an explanation that admittedly seems less than adequate to explain so large a discrepancy; nonetheless, the discrepancy exists.

To compound the imbalance, significant numbers of men joined the clergy and secular priesthood, thereby eliminating even more men from the marriage market. In Lübeck, for example, there were some 300 or 400 men out of a population of 25,000 who did so. ${ }^{233}$ Thus, it is clear that not all women could marry. Among those who did, it should not be surprising to find some marrying old men. After all, such a marriage was probably preferable to life in a convent or a brothel.

Contemporary reports from as early as mid-thirteenth century inform us that women in general outlived men. Writings of academics like Albertus Magnus, the most prominent medieval biologist, and laymen like Louis de Mâle, suggest that from the cradle to the grave, women outnumbered men.

The marriage in 1284 of fourteen-year-old Agnes of Burgundy to sixty-year-old Rudolph I of Hapsburg (1281-91), German king, uncrowned emperor, and founder of the Hapsburg dynasty, ${ }^{234}$ is probably not a case in point, because it served political ends. But it certainly does remind us of the fact that marriages were arranged. In this case, the age of the suitor was no impediment, as he was distinguished and wealthy, and it seems likely that, generally, high status would compensate for lack of youth. Another marriage that may be mentioned here was that of Berthold Tucher, who was fifty-four in 1346. His second marriage, soon after the death of his first wife, was to Anna Pfintzing, the daughter of a wealthy Nuremberg family, who was only about fifteen at the time. But fifteen was by no means an unusual age for a woman to marry. ${ }^{235}$ (See Handlist no.59.)

The contemporary practice of the morganatic marriage, marriage between members of different social classes which were specifically named in marriage records, can also be linked with the advantage men held in the choice of a spouse, because of their fewer numbers. Marriages between classes began at least in the twelfth century with kings, dukes, and the land-owning classes. ${ }^{236}$ As society changed with the ascendancy of towns, burghers became more important and the aristocracy less so. As we have said, land was losing to gold as the measure of wealth. Not surprisingly, the two classes, nobility and middle class, joined their wealth through intermarriage. In the twelfth and thirteenth centuries, with the formation of a class of lower nobility, which was comprised of ministers, rulers and civil servants, the high nobility began for the first time to marry members of a class other than their own. ${ }^{237}$ 
Andreas Capellanus's De amore describes such early morganatic marriages, and the author discusses intermarriage between members of the middle class, the lower and higher nobility. ${ }^{238}$ A fifteenth-century Middle Rhenish manuscript known in several versions, was illuminated during the closing years of that century. These manuscripts, together with printed editions of the book, from 1482 and 1484, which were complete with woodcut illustrations, attest to the popularity of Capellanus's book. ${ }^{239}$ Capellanus even includes a dialogue between an unequal couple, both of the middle class, in which the woman rejects her elderly suitor, explaining, bluntly enough, "I am rather young and I shudder at the thought of receiving solace from an old man." 240 The practice of marriage between the middle and upper classes was probably fairly common by 1500 .

But as we have noted, in most if not all representations of Unequal Lovers, women are castigated for deceiving men. Could a partial explanation for the tendency to blame women be their greater numbers? Many of them would never marry, and conceivably formed a special category with no well-defined social function. It is interesting to speculate on a relationship between witch-burnings, which reached their peak in the sixteenth century, and the growth of misogynous literature and art, of which the Unequal Couple may in some ways be considered a sub-genre. Could there be a relation between the growing numbers and life-spans of women and the increase in misogynous literature in the thirteenth century, to say nothing of the beginnings of the persecutions of witches at this time? Could the growing population of women have spurred not only the witch-burnings but an anti-feminism which was reflected in art and literature?

All this prompts the question, to what extent are depictions of Unequal Lovers based on real events? In the case of the few representations of young men marrying old women, the explanation is quite simple-burgher marriages were based not on physical attraction but on economics, and were usually negotiated between guild members or those in the same trade. A master's widow, then, would have been a highly desirable marriage partner, even if well on in years, since her young husband would inherit the first husband's shop. ${ }^{241}$ Young women paired with old men, on the other hand, are either prostitutes and their clients, or the legitimized version of this relationship, in which an elderly man acquires beauty or youth through wealth, and his young bride, wealth through beauty. Intermarriage of classes, and the greater numbers of women help to explain these unequal couples. 


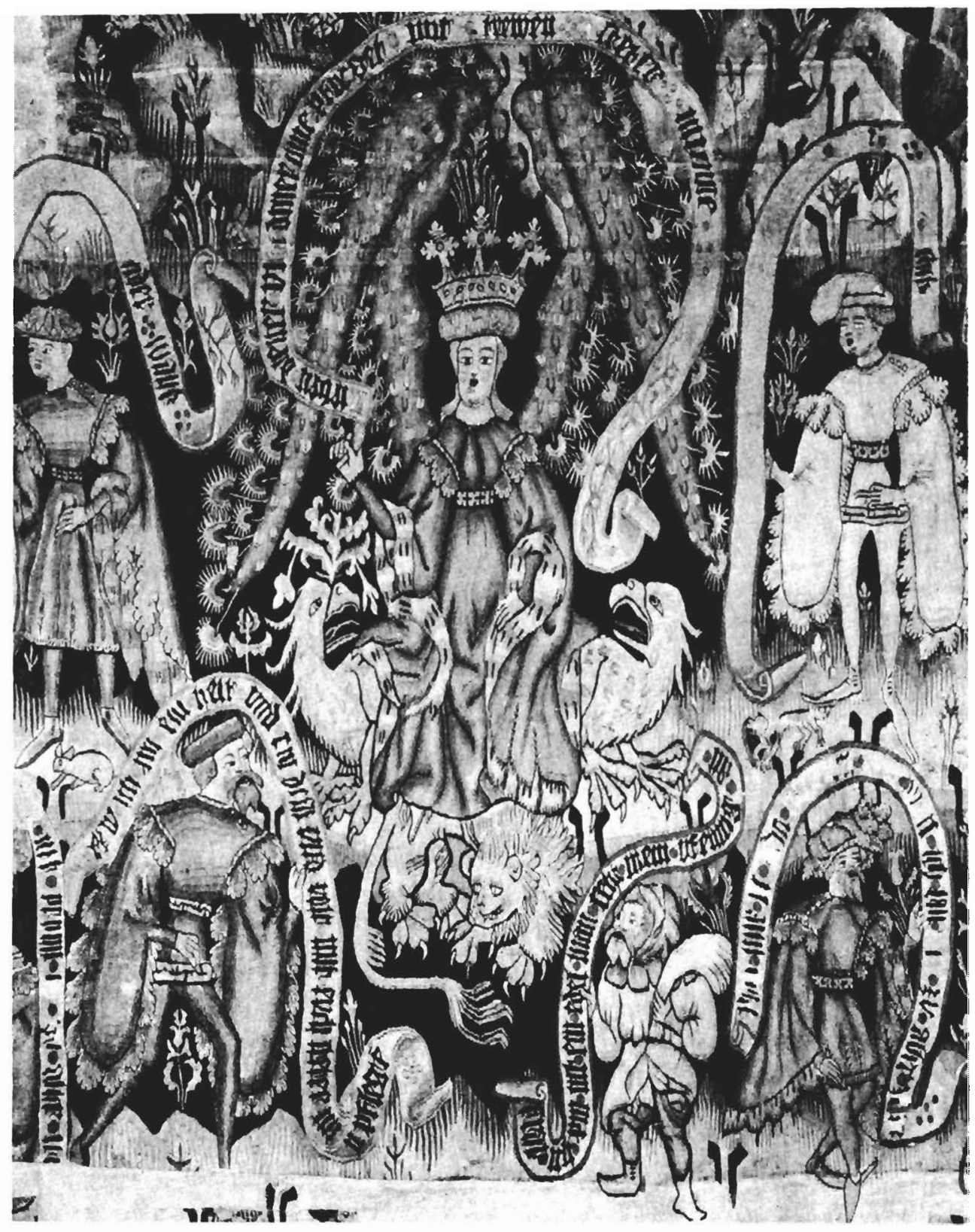

69. Anonymous Rhenish Artist, Dame Venus Deciding Between Noble Gentleman and Burgher with Money Sack, early fifteenth century, tapestry, Regensburg, Rathaus 
The fool, who is commonly included in Unequal Lovers in the guise of the old man, first appears in graphics around the middle of the fifteenth century, when he seems to connote the illicit rather than the sinful. A case in point is a German woodcut of the Nuremberg school, which dates from about 1480, and is unusual for its depictions of a secular subject so early in the history of the woodcut medium, and so soon after the beginnings of Unequal Love as an artistic genre. The woodcut (fig. 70), which shares the basic compositional grouping of Quinten Massys's Washington panel, Old Man, Young Woman and a Fool (see fig. 40), is, like the tapestries mentioned above, related to the theme of the Power of Women. A young couple, seated, embrace in an enclosed garden. The man fondles one of his consort's breasts, and she chucks his chin while in the act of stealing from his open purse. The key to the interpretation of this woodcut is found directly over the young man, where an ape regards itself in a mirror. The inscription, damaged by cropping, explains that the woman "makes a monkey" of her lover. Janson states that

The simian . . . brands the youth as a vain fool deprived of all elementary foresight by his amorous desire. . . . By this time, however, the subject has lost its poetic or philosophical implications so completely that it is visualized in terms of satirical genre. 242

In representations of Unequal Lovers, the fool seems to have served a similar and possibly more inclusive function: to satirize those foolish old lovers who have not the sense to know or even care that they are being taken advantage of - and by women at that. Their old age and infirmity only make their pretensions more ridiculous. The young partner-most often female-knows exactly what she is getting herself into. That old people may well act foolishly, and in a manner unsuited to the wisdom believed to accompany their advancing years, is as well known today through proverbs (e.g., "there's no fool like an old fool") as it was four or five hundred years ago, when the Dutch equivalent, "Gy en siet so oudder so sotter" ("The older the more foolish"), was included in a painting of this theme by Jan Massys. ${ }^{243}$

The fool may be symbolic of a variety of moral qualities ranging from harmless gaiety to sinfulness, but something midway between the two, i.e., the lack of common sense and foresight, generally applies to the fools in scenes of Unequal Lovers. ${ }^{244}$ The fool's function is to satirize the ridiculous behavior of men, and, as Favis states, " . . . the weakness which makes them such easy marks for women's wiles." 245

But where the fool is depicted or implied, the tone is generally rather lighthearted, suggesting and recalling the tolerance and amusement found in 
late medieval writings. 246 This view can be specifically contrasted with that of Brant's Narrenschiff, where it was a culpable folly which was depicted. Unequal Lovers scenes, with their humorous and blameless fools, probably served as recreation and amusement. In the late fifteenth century, the antics of the fool, whether in town squares or at court, were a cathartic means of relieving the pressures of conforming to the demands of civilization. Audiences laughed at the fool, while at once condemning and envying him for his freedom from official censure. The old fool in an unequal relationship exhibits similar unorthodox antics. Did the Unequal Couple theme in art serve to encourage as well as to satirize the pairing of such couples? 247

Anyone who was a slave to the passions, another aspect of folly, was considered a fool, so that elderly lovers certainly qualified. And a contemporary proverb defined a fool as a seeker of the impossible. ${ }^{248}$ If this idea was known in the North, it would have made the old lover a fool on

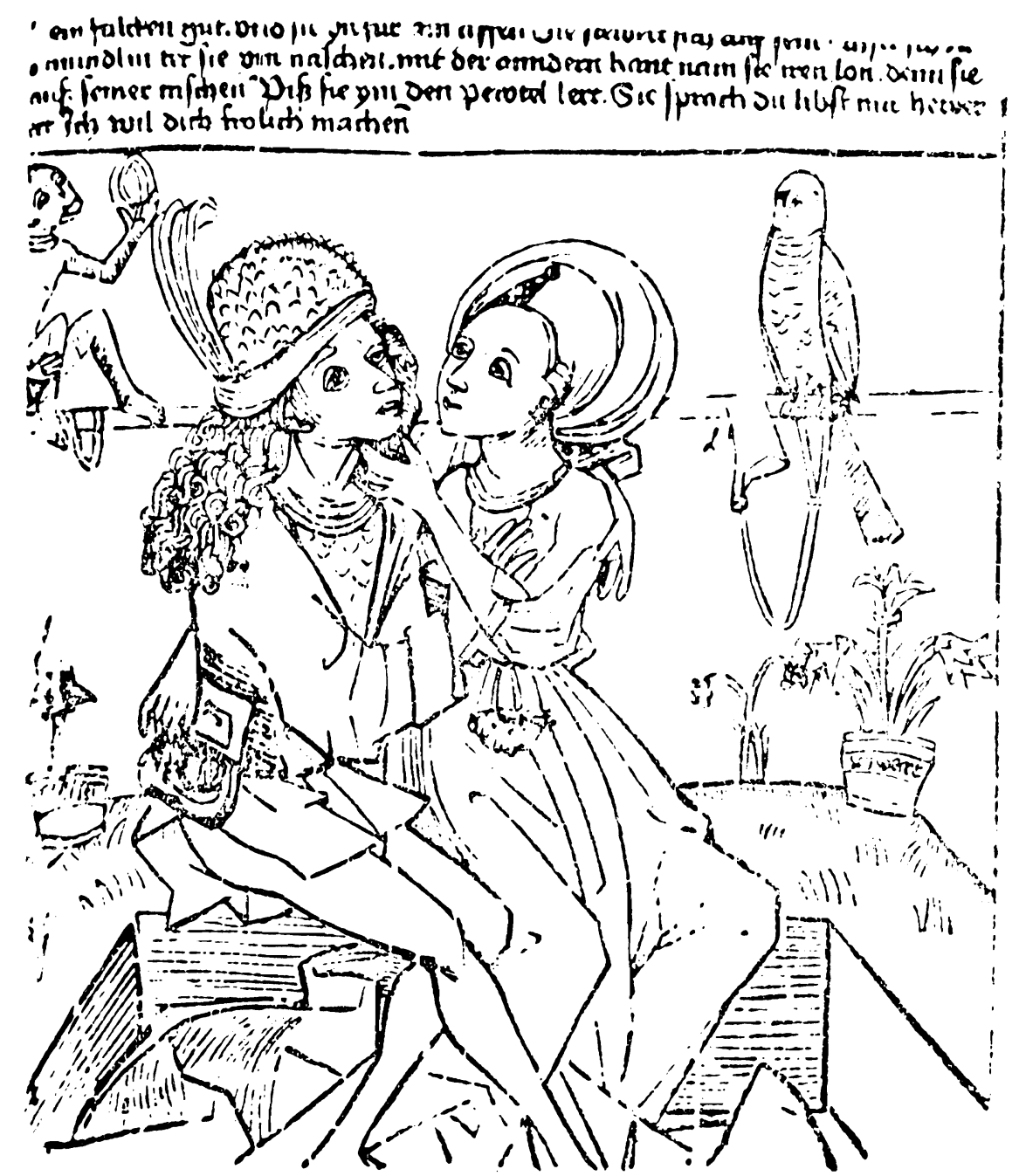

70. Anonymous Nuremberg Artist, Embracing Couple with Ape, ca. 1480 , woodcut 
a double count, since a sexual relationship with a young woman was something which old men were considered ill-equipped to sustain.

The greatest variety and relish in the depiction of the fool occurred in the French and German vernaculars, especially in German carnival plays. As we have seen, the fifteenth-century carnival play abounds with men whose lustful behavior marks them as fools, very like the fools in scenes of Unequal Lovers. The satirical spirit of these plays, with their frequent allusions to lovers as fools, coincides with the contemporary rise in popularity of "folly" and "the fool" as themes in literature and art.

In light of the search for transitory love and money, a small number of Unequal Lovers can be understood as representations of vanitas or memento mori, which is suggested by the presence in them of skulls, skeletons and inscriptions; in some late representations of the 1520 s, Death is shown with a nude woman, and eroticism literally enters into the picture as well. The vanitas theme was depicted in the more traditional and moralizing woodcut medium by Urs Graf around 1511 (fig. 6), and in Cranach's Payment in Stockholm of 1532 (fig. 52). The warning inscriptions in Graf's print and in Strigel's 1502 chiaroscuro drawing in Berlin (fig. 63) may reflect traditional morality paired with new iconography, or they may be attempts at providing "redeeming social value" in these otherwise delightfully worldly depictions.

The moralizing element in most representations was probably small. The level of slick sophistication and lightheartedness, especially in early Unequal Couples, suggests strongly that engraved representations arose more from the specifically erotic and satirical taste of a particular group-humanists, perhaps? - than from any demand for new moralizing material. Though moralizing may have come into play, in most cases it was probably secondary at best. The melancholic tone of Baldung's and Jacopo de' Barbari's works (figs. 57 and 66), and the vanitas elements, mentioned above, do indicate some moralizing concerns, but the inclusion of such elements would not have excluded the probability that representations of Unequal Lovers were meant to entertain and delight their audience,' not only to instruct it. Would anyone, especially if involved in such a relationship, actually have heeded the ostensible warnings of such titillating works of art? ${ }^{249}$ And even if not actually involved, could anyone have failed to notice the erotic and playful elements of them?

In connection with the question of audience response, it must be borne in mind that the fifteenth and sixteenth centuries were, especially in the North, a time in which the limits of polite speech and behavior were considerably wider than in our own time. One has only to consider the writings of so seriously intentioned a figure as Martin Luther to obtain a sense of the difference between his standards of what was permissible, and our own. Sexual license was institutionalized and freely referred to: Emperor Maximilian was famous for the four or five Schlafweiber ("women to sleep with"), who traveled in his retinue; and trains of lansquenets always included Huren weibeln ("prostitutes"), who are frequently shown in woodcuts of the period. 


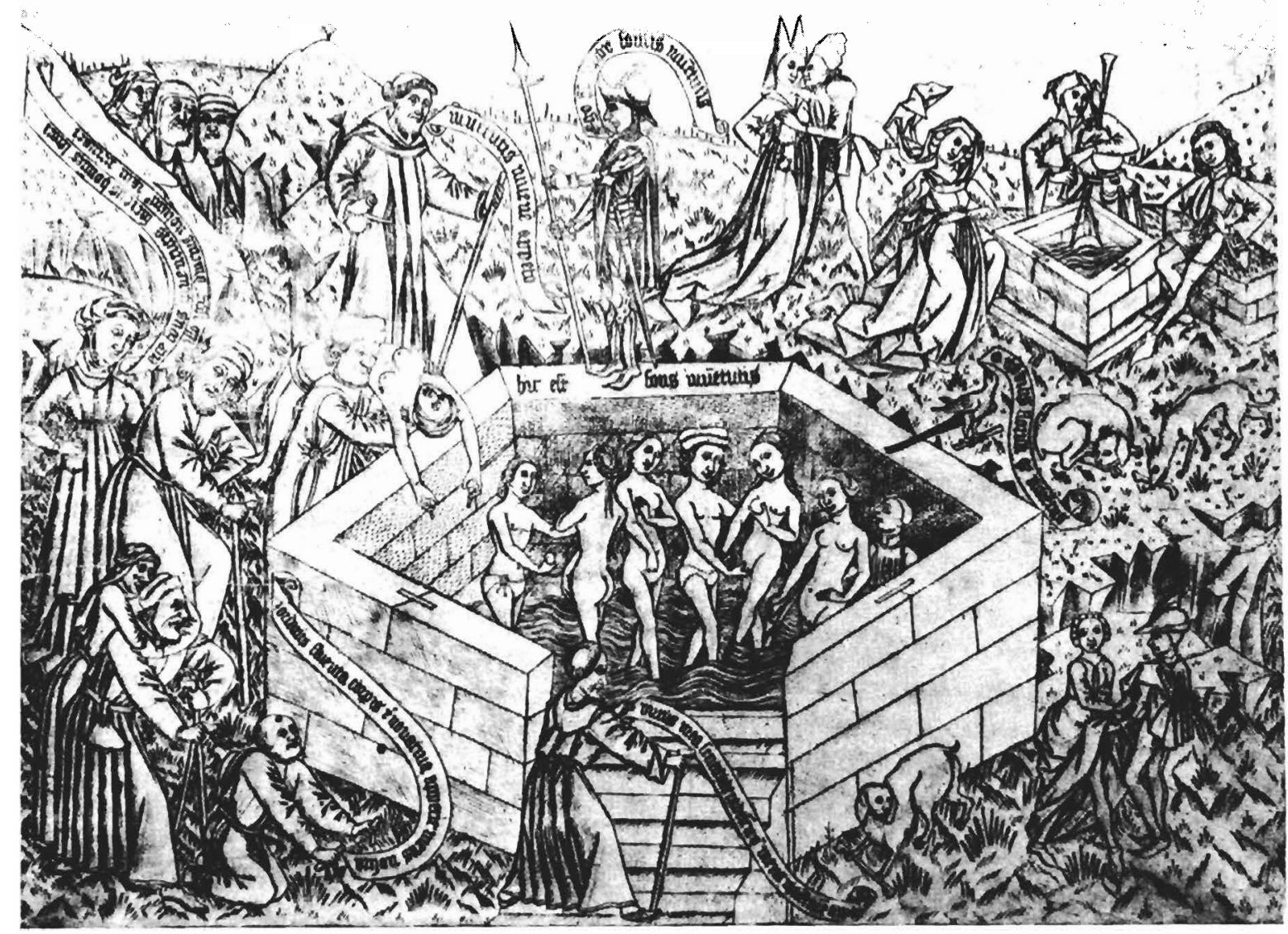

71. Master of the Banderoles, Fountain of Youth, 1450-1475, engraving

Early Pornography and Contemporary Taste

The openly erotic content of the Unequal Lovers theme should therefore not be underestimated. In time it increased: the suggestive placement of the man's hand, as if drawing near the woman's breast (fig. 14), is later transformed into the more explicit fondling of her exposed breast (fig. 58). Her dress exposes her nipples (fig. 56). In Love Triangles a nearly naked woman may be shown full length (not, as in most Unequal Couples scenes, in half-length), between an old suitor and a young one. The presence of these overtly sensual elements points to an interest in the theme in part for its erotic potential.

Graphics once again provide a historical context from which Unequal Lovers emerged, a context that might be described as early pornography. Blatantly erotic art is to be found in engravings since the middle of the fifteenth century. The oeuvre of the Master of the Banderoles, for example, includes some interesting examples; ${ }^{250}$ Fountain of Youth (fig. 71) depicts nudes in overtly sexual play, in a structure that looks more like a high-walled swimming pool than a fountain. Interestingly enough, the left half of the 


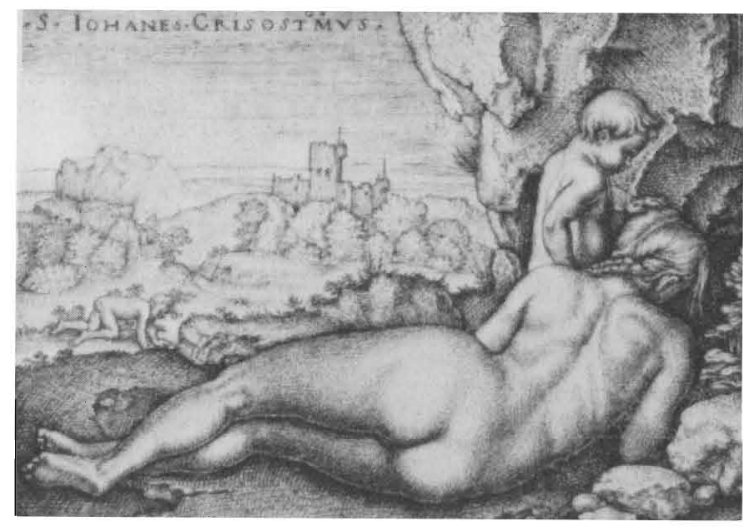

72. Hans Sebald Beham, The Penance of St. Chrysostomus, ca. 1525 28, engraving.

composition contains a number of old men whose capacities for lustful action will be restored only after a splash in the fountain. Master E.S., after whom the group with the fool at the top right was copied, engraved the same type of subject. He goes even further, however, for in a few instances he actually depicts the nude genitals of both sexes, which is most unusual for the time. E.S. also takes advantage of erotic punning, as when a woman plays with a man's gown flap and dagger, which hang before his lap. ${ }^{251}$ (Other early pornographic representations have been discussed in Chapter 2 and illustrated in figs. 12 and 13.)

The lascivious taste of the northern audience, and particularly the German one, seems to have flourished with time, especially after 1520 . Both Altdorfer's Susannah and the Elders of 1526 and his 1537 Lot and His Daughters 252 appear concurrently with other erotic scenes: in Altdorfer's frescoes of about 1532 for the Regensburg Imperial Bathhouse, some fragments of which have been preserved, a nude man and woman recline side by side almost exactly as in the Lot above. ${ }^{253}$ Still more explicit are a number of engravings of nude women and Death executed by Hans Sebald Beham, who was a radical in other ways as well: in 1525 he, along with his brother Barthel, and Georg Pencz, both artists, was banished from Nuremberg for open agnosticism. An engraving by Sebald Beham of 1529, one of the most explicit, depicts a nude couple with Death, in which both man and woman touch each other's genitals. ${ }^{254}$ Other women engraved by Beham are posed in explicitly erotic fashion. The artist himself explained such works as responses to the taste of the time. ${ }^{255}$

Other works of the period exploited the erotic potential of traditional subject matter, like the Old Testament stories of Lot or Susannah, mentioned above, or classical tales like those of Cimon (a Greek general who died in 449 B.C.) and Pero, Cleopatra, Lucretia, Dido, or Leda and the Swan. ${ }^{256}$ Both Dürer and Sebald Beham engraved the Penance of St. Chrysostamus with the saint in the background, rather than in the foreground (figs. 72 and 73). ${ }^{257}$ In Beham's representation the woman for 


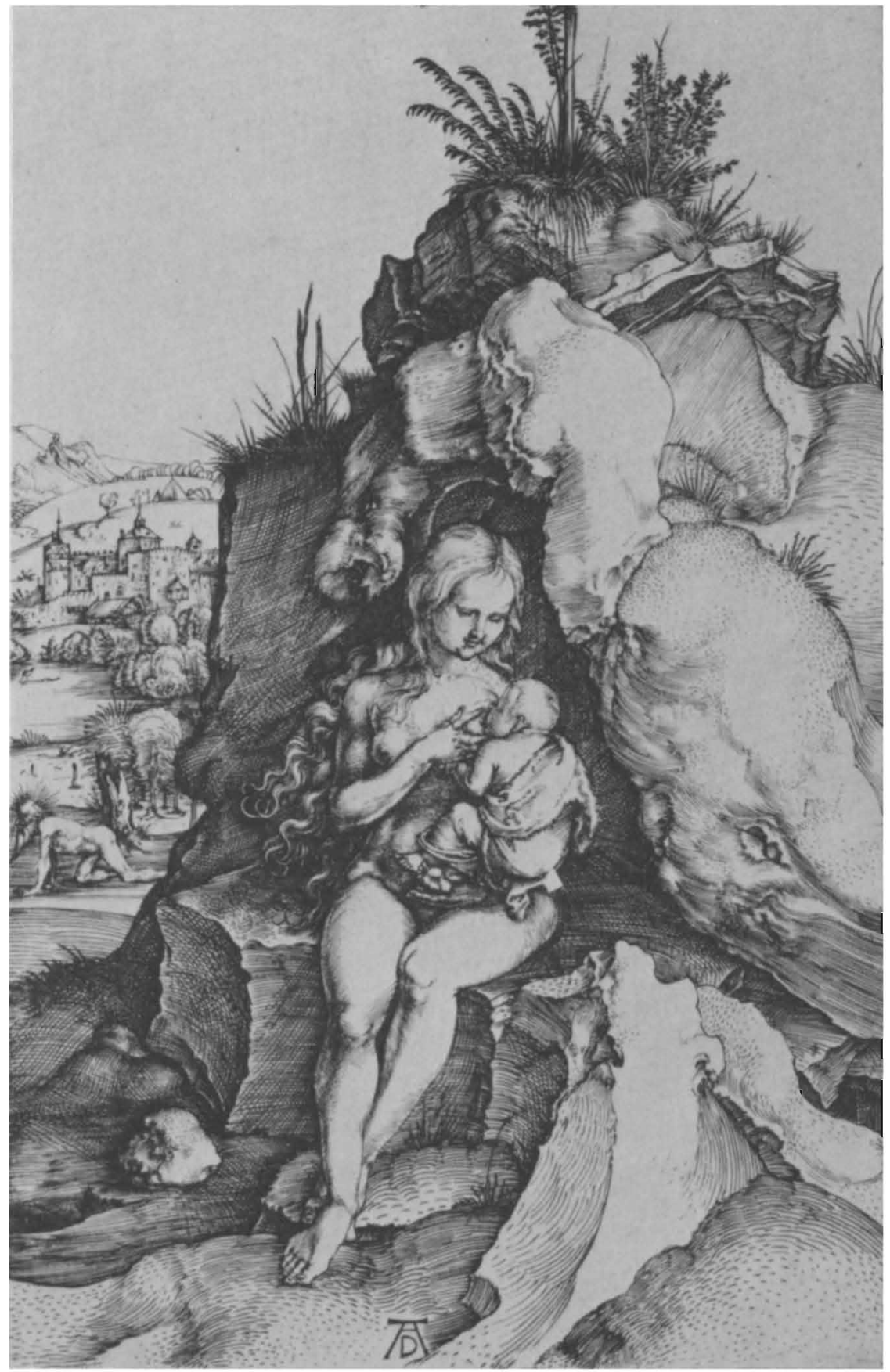

73. Albrecht Dürer, The Penance of St. Chrysostomus, 1496, engraving 


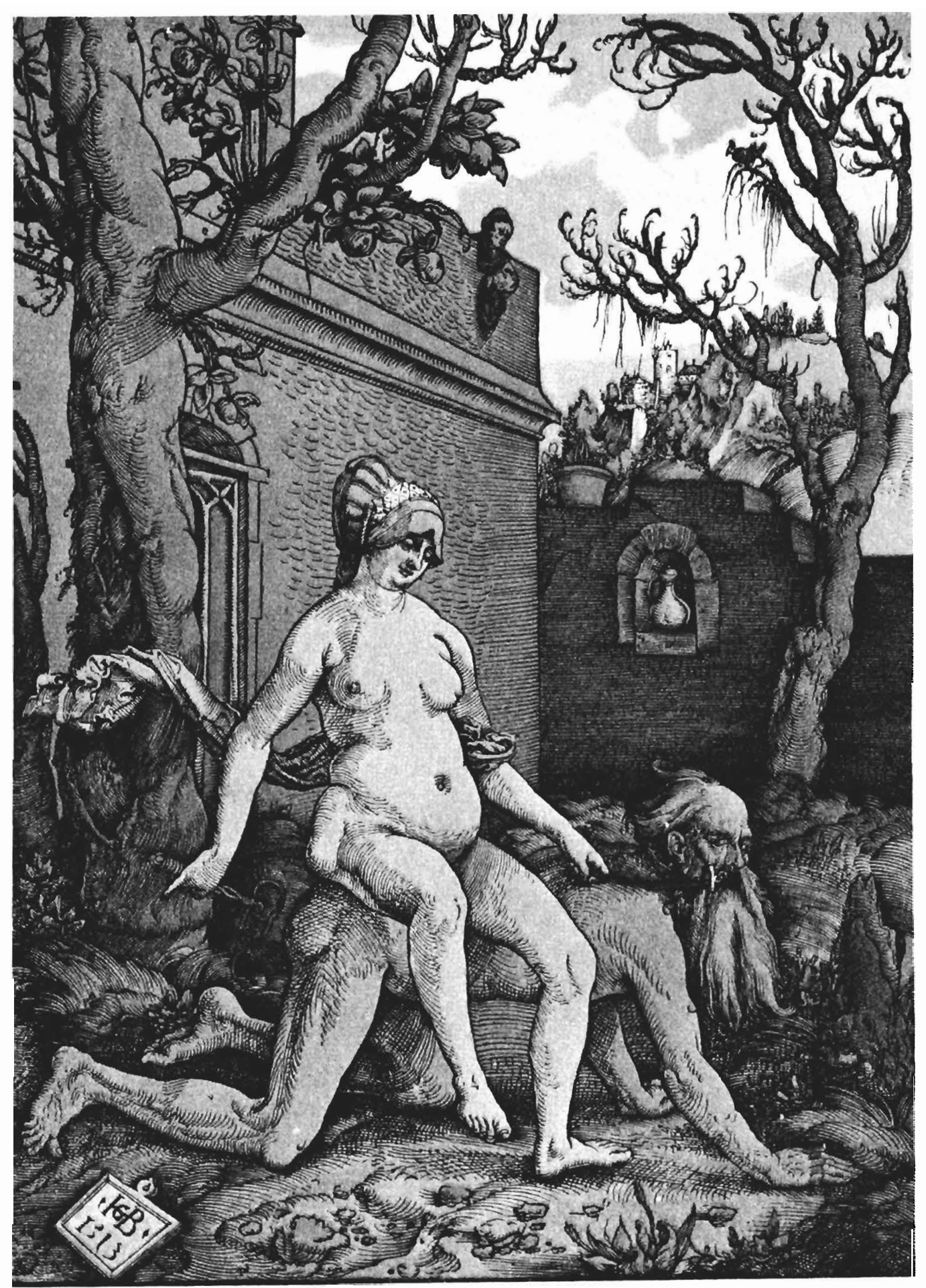

74. Hans Baldung, Aristotle and Phyllis, 1513, woodcut 
whom the saint does penance reclines in the nude across the full width of the foreground. ${ }^{258}$ She is viewed from the back, so that the invasion of family privacy - their child plays with her mother's hair-only serves to heighten the generally erotic tone.

Under the broad heading of quasi-pornographic subjects, we may place both the Unequal Lovers theme and the Power of Women theme. The latter became quite popular during the last quarter of the fifteenth century. As the name implies, it depicted women who had power over men; the erotic content of these depictions was more or less explicit. The theme boomed in engravings, especially in representations of the Samson/Delilah and Aristotle/Phyllis themes, executed by the Housebook Master, Master B R, Master P W of Cologne, and Hans Baldung Grien, among others (see fig. 74). ${ }^{259}$ Especially interesting is the associated theme of the Battle Over the Pants, or the so-called "hen-pecked husband." It was engraved no less than three times by Israhel van Meckenem, who died in $1503 .^{260}$ The popularity of the Power of Women theme continued into the sixteenth century, when it became more common in woodcut. ${ }^{261}$ The depiction of women as the more powerful partners in love affairs was intended to be, and was, construed as negative, and the pejorative impact of such representations was probably not unlike that of those Unequal Lovers scenes in which men were portrayed as fools.

Northern European women were not praised, in the late Middle Ages, for achievement and strength of character in their affairs with men: quite the contrary. Was Delilah popular because she was the Hebrew heroine who struck down the Philistine enemy Samson? Was Phyllis admired for her ability to outsmart Aristotle, the greatest of the philosophers? Unfortunately, the answer is no. In Power of Women scenes, woman was invariably seen in negative and sexual terms: "deceitful" and "lewd" was the behavior of a woman who was able to gain power with what means she had.

Furthermore, woman was blamed for the folly of man. If an old man bought a young woman's sexual favors, the fault was seen as hers. The moral paradigm has persisted, of course, throughout centuries of the criminal prosecution of prostitutes, while their clients are ignored. But woman is blamed so often in the art, literature and philosophy of the period, that the imbalance goes unnoticed. As daughters of Eve, after all, they were suspect from the first.

The Unequal Couple, whether composed of a young woman and an old man or a young man and an old woman, upset the "natural" order in a variety of ways. In either case, the woman seemed to have more real power than she ordinarily had. No longer did the Masculine and Rational rule over the Feminine and Emotional, for whether by virtue of her good looks or her purse, the woman was shown in a decision-making position. The reversal of roles was probably referred to through the ambiguous dress in a painted panel from the circle of Lucas van Leyden (fig. 75). 


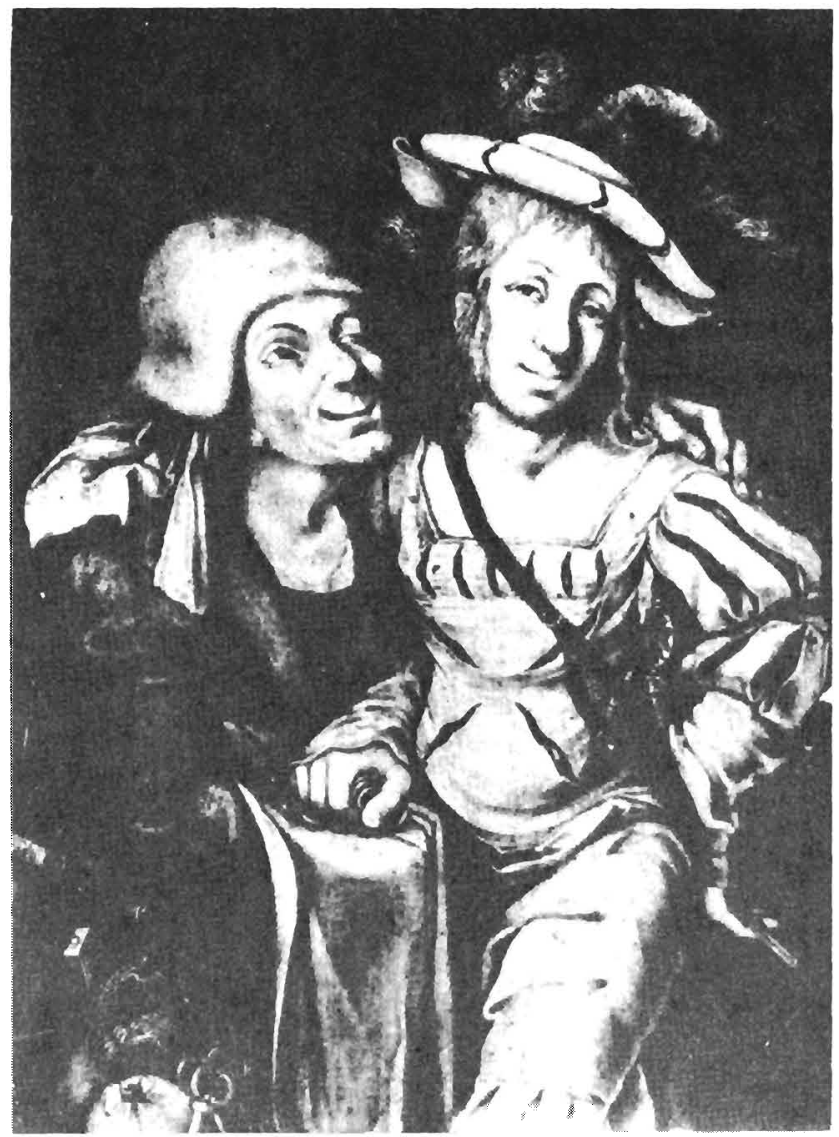

75. Circle of Lucas van Leyden, Old Woman and Young Man in Woman's Dress, 1520-30, panel, Netherlands, Private Collection

Both the Power of Women theme and the Unequal Couple theme therefore operate as double-edged swords. Each may be taken as a statement either feminist or misogynist in thrust. Women in unequal relationships are seen as active, decisive, determined individuals; these qualities, traditionally viewed as masculine, were counted as positive if met with in males, but negative in females. For "unnatural" read "active"; for "cunning," "decisive", for "conniving," "determined."

The power of population circumstances, which encouraged young, attractive women to marry older partners, ultimately led to their being considered "money hungry." But gain through marriage was nothing new, as nearly all marriages involved the exchange, between families, of gold or land. The crux of the matter was that in Unequal Lovers scenes, a woman took her affairs-often literally her gold-into her own hands. 
The Popularity of "Unequal Lovers"

The popularity of the Unequal Lovers theme ca. 1500 is demonstrated not only by the numerous representations of the theme that have come down to us in literature and in the graphic arts but also by the many copies included in this study: Marcantonio Raimondi (fig. 76) copied Duirer's engraving (fig. 1) in reverse; Hans von Kulmbach (fig. 77) duplicated Baldung's 1507 engraving (fig. 58) in paint; Graf's woodcut (fig. 6) may have been executed after a lost prototype that is also reflected in a woven cushion cover of mid-century (fig. 78); the anonymous Nuremberg Love Triangle woodcut of ca. 1525 (fig. 47) is reflected in two others (figs. 48, 49); an etching after Lucas van Leyden (fig. 43) seems to have been copied in an anamorphic woodcut by Erhard Schön (fig. 44); and finally Cranach, his school and his sons executed some forty painted versions of the theme (see Handlist).

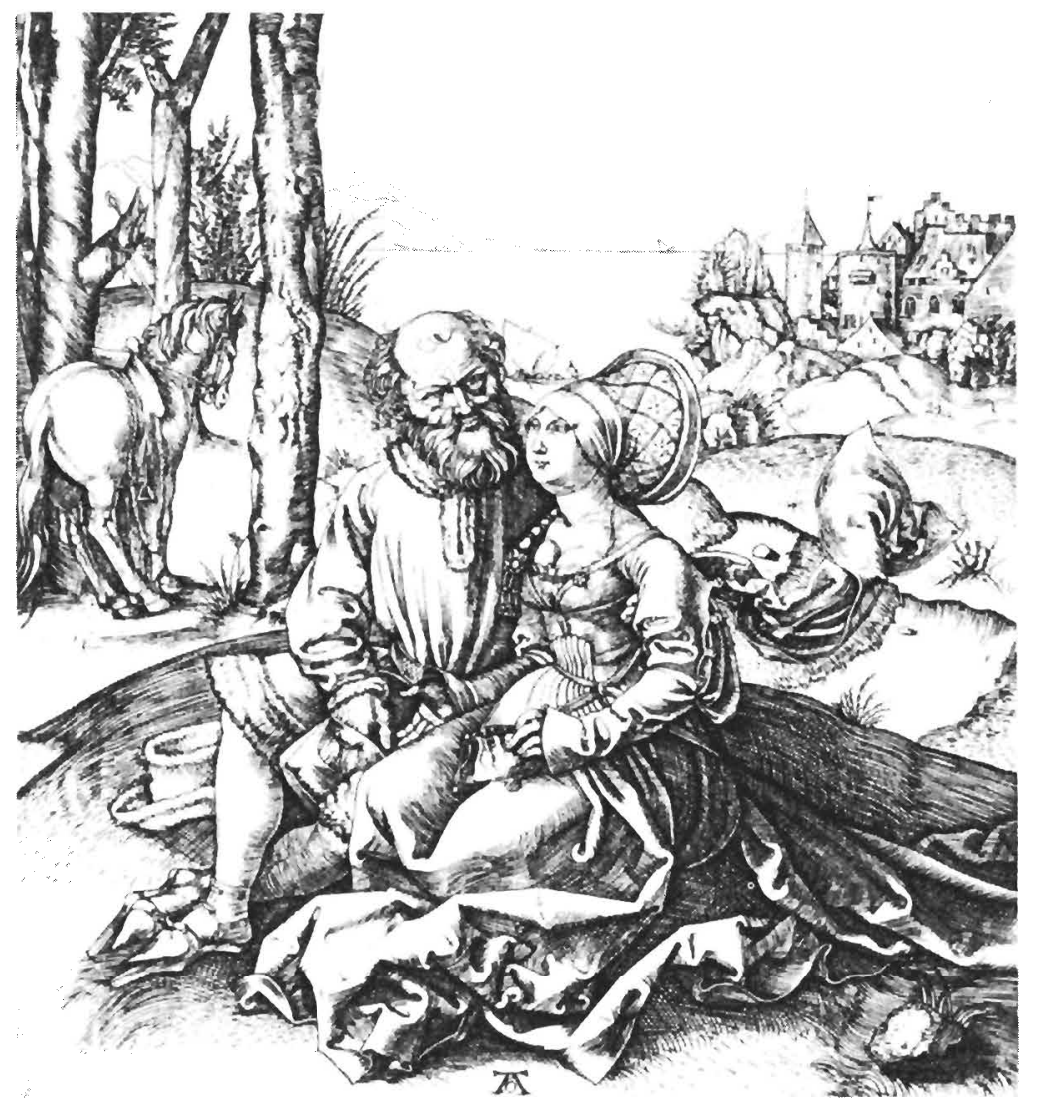

76. Marcantonio Raimondi, Old Man and Young Woman, before 1505, engraving 


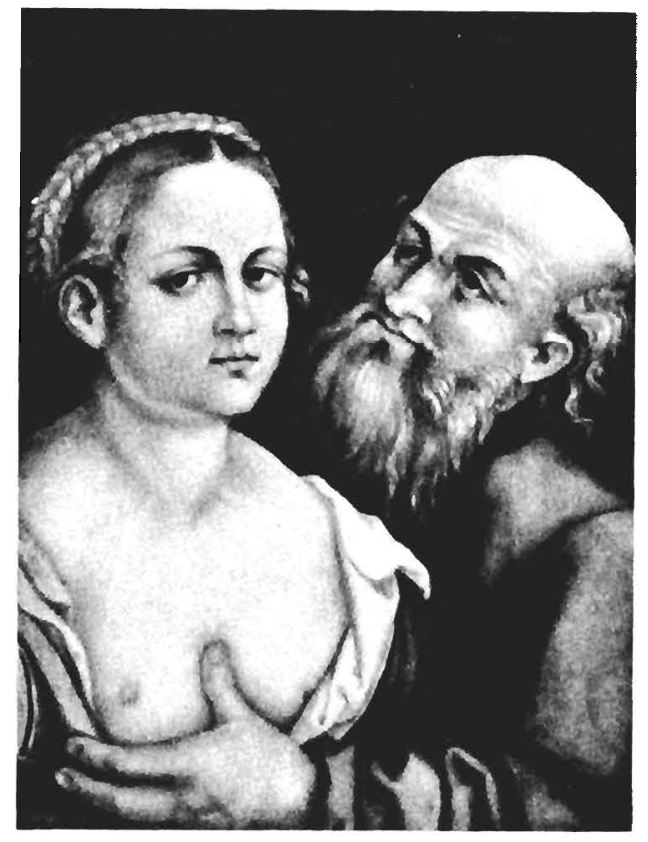

77. Hans von Kulmbach, Old Man and Young Woman, ca. 1510, panel, Private Collection

Why was the theme of Unequal Love so popular in the visual arts around 1500? Its popularity may simply have been an extension of the tendency in engraving to satirize the follies of love. That contemporary social realities like the increasing importance of money in the newly emerging German capitalist society actually forced, or at least encouraged, such relationships is a suggestion which has already been made. As we have said, too, the inventions of engraving and the printing press contributed to this process.

The surge in popularity that the Unequal Couples theme underwent in painting in the 1520 s, especially with Cranach, also calls for some explanation. Was it that by then sufficient time had passed since the introduction of the theme into the graphic arts to allow for the growth of a new audience of patrons who would order paintings of it? Or, have a significant number of paintings of the theme predating 1520 not come down to us for some reason, thus distorting our view of its earlier popularity? Only four paintings date before 1520: Jacopo's 1503 panel (fig. 66); the questionable 1509 Master d H (fig. 79); the Kulmbach copy after Baldung's engraving (fig. 77); and the Jacob Cornelisz. van Amsterdam painting (fig. 33). An inventory from the collection of an official of the chambres des 
comptes in Brussels, one Cornelis Haveloes who died in 1505, includes a painting of an Unequal Couple that is described as "an old man and a young woman" ("eenen ouden man ende een jonk wyf"). ${ }^{262}$ The painting, which has, thus, a terminus ante quem of 1505 , is not known today, nor is a contemporary replica of the 1503 Jacopo panel, now lost but recorded in Berlin in 1920. ${ }^{263}$ Jacopo may also have painted an old male lover mocked by a fool (a variation of the Unequal Couple scenes?), a painting listed in the 1507 inventory of Wittenberg castle but no longer extant. (See Handlist no. 8.)

Perhaps a large number of the 1520 s paintings were commissioned at one particular court, where interest in paintings with such erotic content ran high. Frederick the Wise, the Saxon Elector at Wittenberg, was Cranach's patron from 1505, when that artist replaced Jacopo de' Barbari. Prior to 1503, Jacopo had, for a brief time, worked as painter and miniaturist for Emperor Maximilian and resided principally in Nuremberg, ${ }^{264}$ and he may have painted the Philadelphia panel during his two years with Frederick the Wise at the Saxon court. Cranach too executed most of his paintings for the court of the Elector. Cranach and members of his workshop produced numerous representations of the theme, varying them only slightly to make each one unique, since obviously a considerable demand existed for such subjects, socially acceptable yet intriguingly erotic.

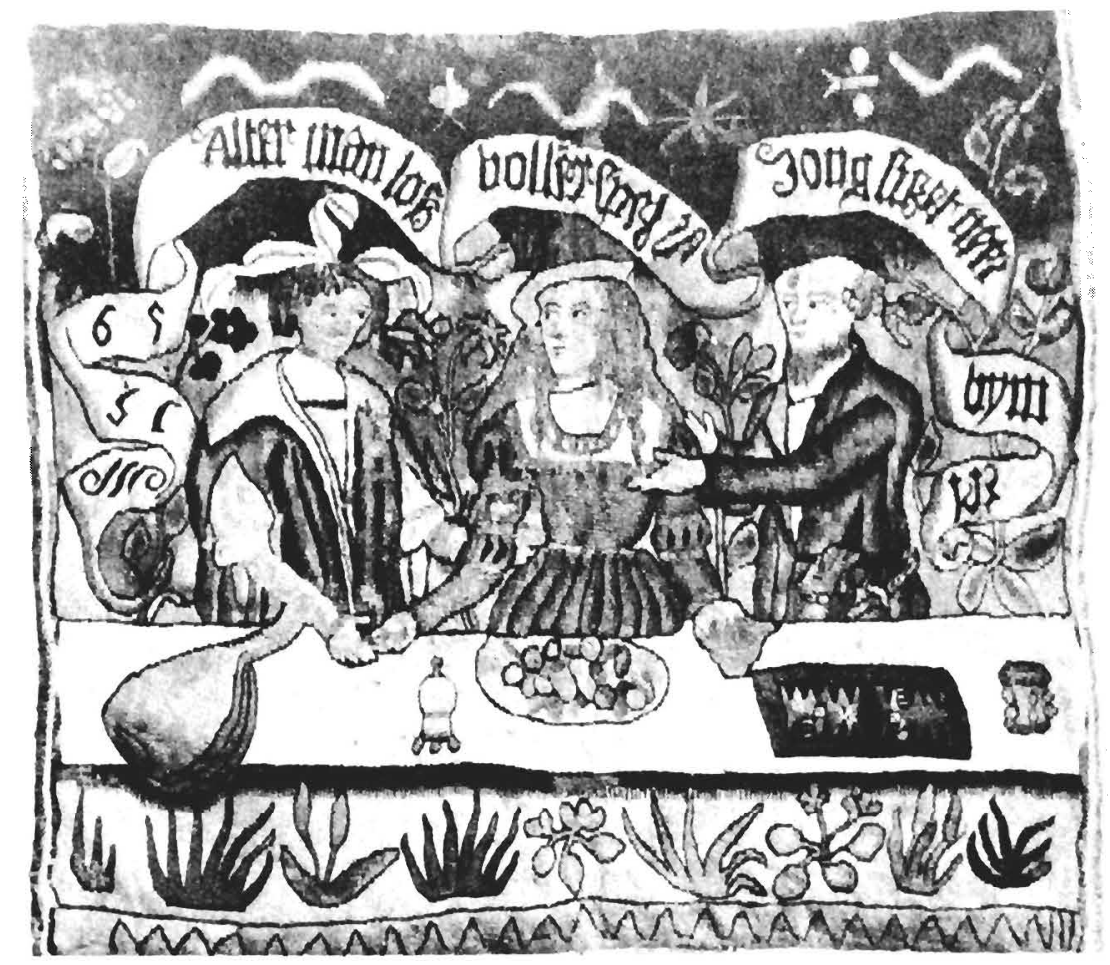

78. Alsatian or Swiss, Love Triangle with Symbols of Pleasure, 1559 or 1565 , woven cushion cover, formerly Vienna, Figdor Collection 


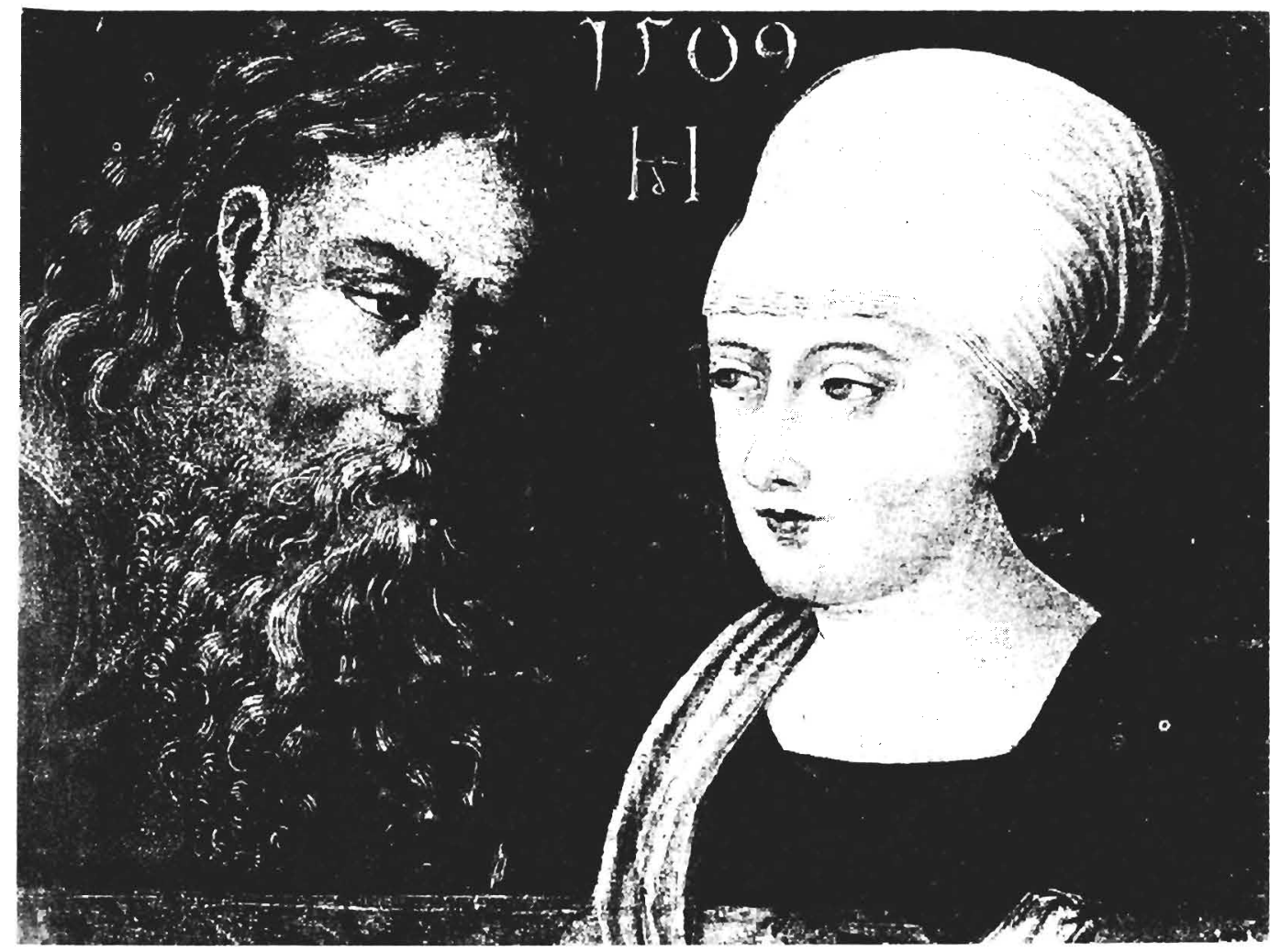

79. Master d H, Old Man and Young Woman, 1509, paper on panel, Nuremberg, Germanisches Nationalmuseum

Audience

How large was the Unequal Lovers audience and who comprised it? Prints quite naturally enjoy a wider audience than paintings, and those who purchased prints did not usually belong to as monied a class as those who commissioned paintings. The difference between the patrons of paintings and the audience for prints is largely one of means.

A patron would usually go to an artist and commission a work from him, whereas the audience for graphics would choose among whatever was offered, and hence comprised a competitive market in the modern sense. The artist who produced graphics endeavored to meet his audience, and to have others work for him so as to sell more prints. Dürer's graphics, for example, were sold by his wife Agnes and by his mother (who died in 1514) at the Heiltumsfest market in Nuremberg and at great fairs in such cities as Augsburg, Frankfurt and Ingolstadt. And there were other ways in which Dürer's prints were distributed:

The wagon of friendly Nuremberg merchant families such as the Tuchers and the Imhoffs carried parcels of Diirer's prints throughout the land. The robber knight Kunz Schott once 
seized a package of Diirer's works-and was probably disappointed with his booty! Colporteurs like Jacob Arnolt distributed the prints. ${ }^{265}$

Dürer's prints were certainly popular in the sense that there was a large market for them, but can we be any more specific about that market? The two principal graphic media that Duirer employed, woodcuts and engravings, throw some light on the nature of his audience. It is well known that woodcuts were easier to print than engravings, not only because a wood block, being "type high," fits on to the printing press, but also because a block did not need the enormous pressure required to pull the ink from the small incised lines of an engraved copper plate. In addition, a wood block did not require meticulous wiping before printing, and the actual cutting of the block was a less intricate and perhaps less time-consuming process because the material involved was not receptive to intricate work. Finally, and perhaps most importantly, the delicate copper plate wears down long before the wood block, and thus yields far fewer impressions, only about two to five hundred for one engraved plate. ${ }^{266}$

The prices of woodcuts and engravings reflect these differences in technique. When Dürer visited Antwerp in 1520/21 he sold sixteen sets of his Small Woodcut Passion (thirty-seven subjects) of 1511 for four florins, while only six sets of the Engraved Passion (sixteen subjects) cost as much as three florins. ${ }^{267}$ A single engraving, therefore, cost over four times as much as a woodcut. The higher price of engravings in part accounts for the fact that they generally contain more erudite subject matter than that of the less expensive woodcut medium. Woodcuts often made use of conservative, religious subjects in the fifteenth and early sixteenth centuries, for, as a rule, the less educated the audience, the more traditional was its taste. Similarly, the more educated strata seem to have been more receptive to untried and novel ideas. Innovative subject matter would therefore have been looked for in engravings, which were directed to a wealthy and better educated audience, one that could afford to experiment.

It was probably the middle class, in fifteenth-century Germany, which provided the audience for much of the burgeoning new secular art of engraving. Around 1430 the Master of the Playing Cards appears as the first master of engraving to depict the secular in that medium. But by the last quarter of the fifteenth century, when Unequal Couples emerged as an independent subject, the interest in the secular and the need for nonreligious and untraditional diversions became significant, perhaps by now, in the new middle class, whose members had made notable gains in wealth and education. Unequal Lovers as a theme may have been a response to the demand for entertainments with erudite associations, for entertainments they were. They may even be called the television of the time, as Lotte Brand Philip has suggested. ${ }^{268}$ 
A particular audience may account not only for the existence of many of the early Unequal Lovers, but also for the fact that they appeared in the medium of engraving, which undoubtedly reached the new humanist audience. Jane Hutchison has recently shown that the Housebook Master's drypoint Aristotle and Phyllis illustrated a specific fifteenth century carnival play. This play was the center of a dispute in a circle of learned men and proto-humanists including Sebastian Brant, Rudolf Agricola and Geiler von Keisersperg. The group they belonged to called itself the Via Moderna, and opposed the Via Antiqua, a philosophy based on the logic of Aristotle. ${ }^{269}$ The Housebook Master's Unequal Couples scenes may, like his Aristotle and Phyllis, also have been inspired in similar circles by a carnival play such as $A$ Play About Marriage, discussed earlier (p.23), or another that has not come down to us.

All members of the Unequal Lovers audience need not have viewed these works on the same level. What the new bourgeois may have considered a scene from contemporary life, a stock comic subject, or a scene from a carnival play, the humanists may have understood as the visualization of a literary work known in their circles.

The association of Dürer's engravings in general-and possibly his engraved Unequal Couple in particular-with a learned, humanist audience has been noted recently:

Dürer's etchings and engravings must have been at least in part conceived as a sophisticated branch of his artistic production, addressed to the narrow circles of his humanistic friends and acquaintances, with Willibald Pirckheimer as the dominant figure, and one who often served as an advisor on subject matter. 270

The individuals who purchased early chiaroscuro drawings, including Strigel's 1502 Unequal Couple with a Demon and Putto (fig. 63), may have traveled in similar circles; certainly they belonged to a monied class. Later, in the 1520s, when Quinten Massys painted his Unequal Couple with a Fool (fig. 40), he seems to have had a group of learned, intelligent and financially comfortable patrons in the Netherlands. ${ }^{271}$ In the same decade Cranach painted secular works for the electors of the Saxon court, the nobility and the influential burghers. ${ }^{272}$

It was probably the same group that constituted the patrons of Cranach's many Unequal Lovers. But other contemporary representations, such as those by Master B R (fig. 30), may have been purchased largely by a less educated class, whose members had become familiar with the theme through carnival plays and other popular literature. Such literature suggests an audience lower on the social scale than that for engravings. That there exist both woodcuts and engravings of the Unequal Couples theme is in itself an indication that the audience crossed class lines. 


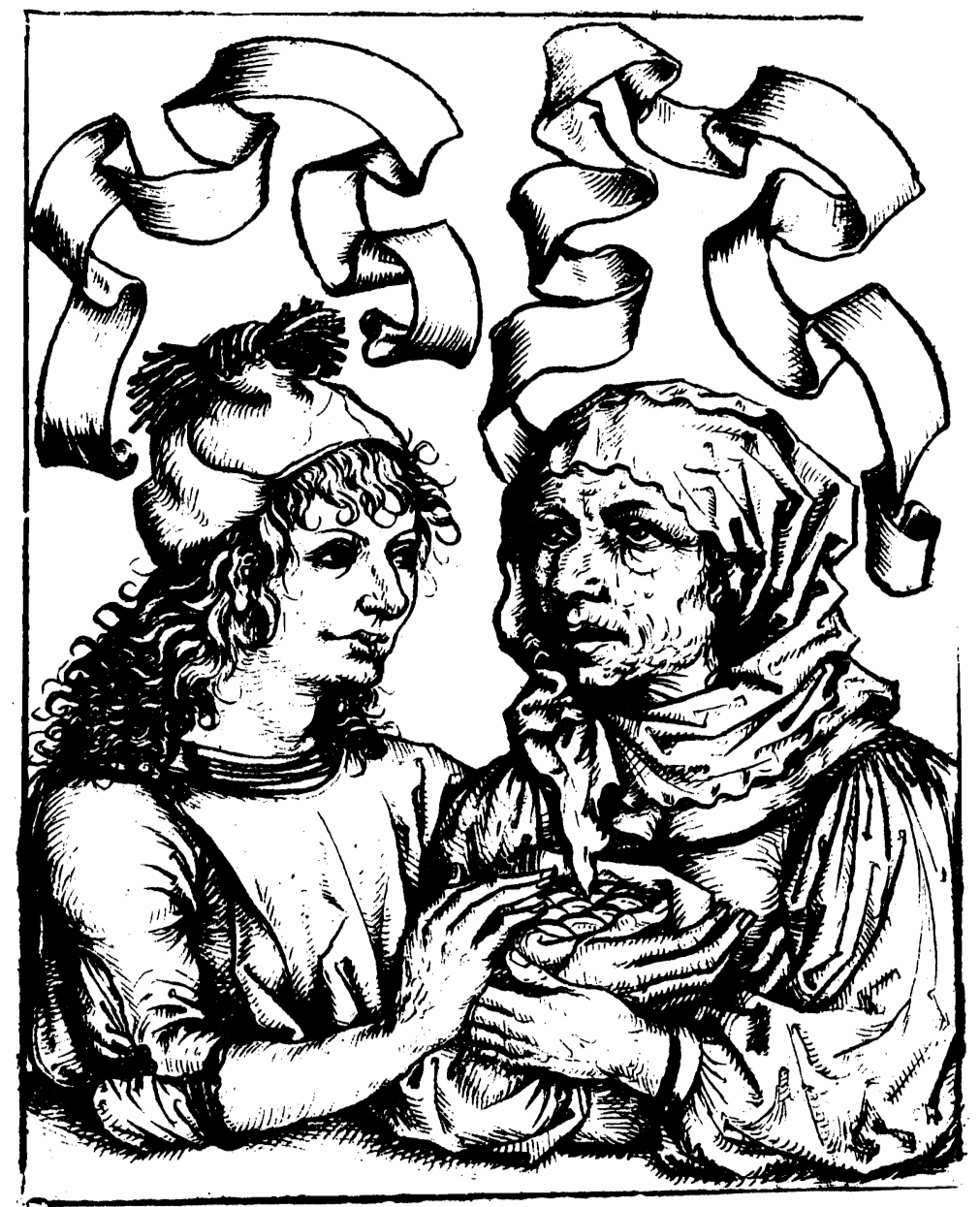

80. The Housebook Master, Old Woman and Young Man, ca. 1475-78, drypoint

In fact, the phenomenon of Unequal Lovers in art bears an intimate connection to what must have been the bewildering economic, social and political changes that marked the fifteenth and sixteenth centuries in northern Europe. And, as we have seen, it was not only men's and women's disparities in age that prompted visual comment from contemporary painters and printmakers, but the related and certainly more fundamental apprehension of the uses and abuses of sexuality as a negotiable item. And while this was surely not the first time that youth and sexual attractiveness were bought and sold for coin, it is, at least in Europe, the first time that a popular consciousness of the satiric possibilities of the theme can be visually documented.

Erhard Schön's Cage of Fools (fig. 81) is a rather emblematic allegorical presentation of the dynamics of marketplace sexuality as they were most often presented to the contemporary audience: i.e., hapless men, imprisoned in a cage that burns with the fires of lust, must sing to the 


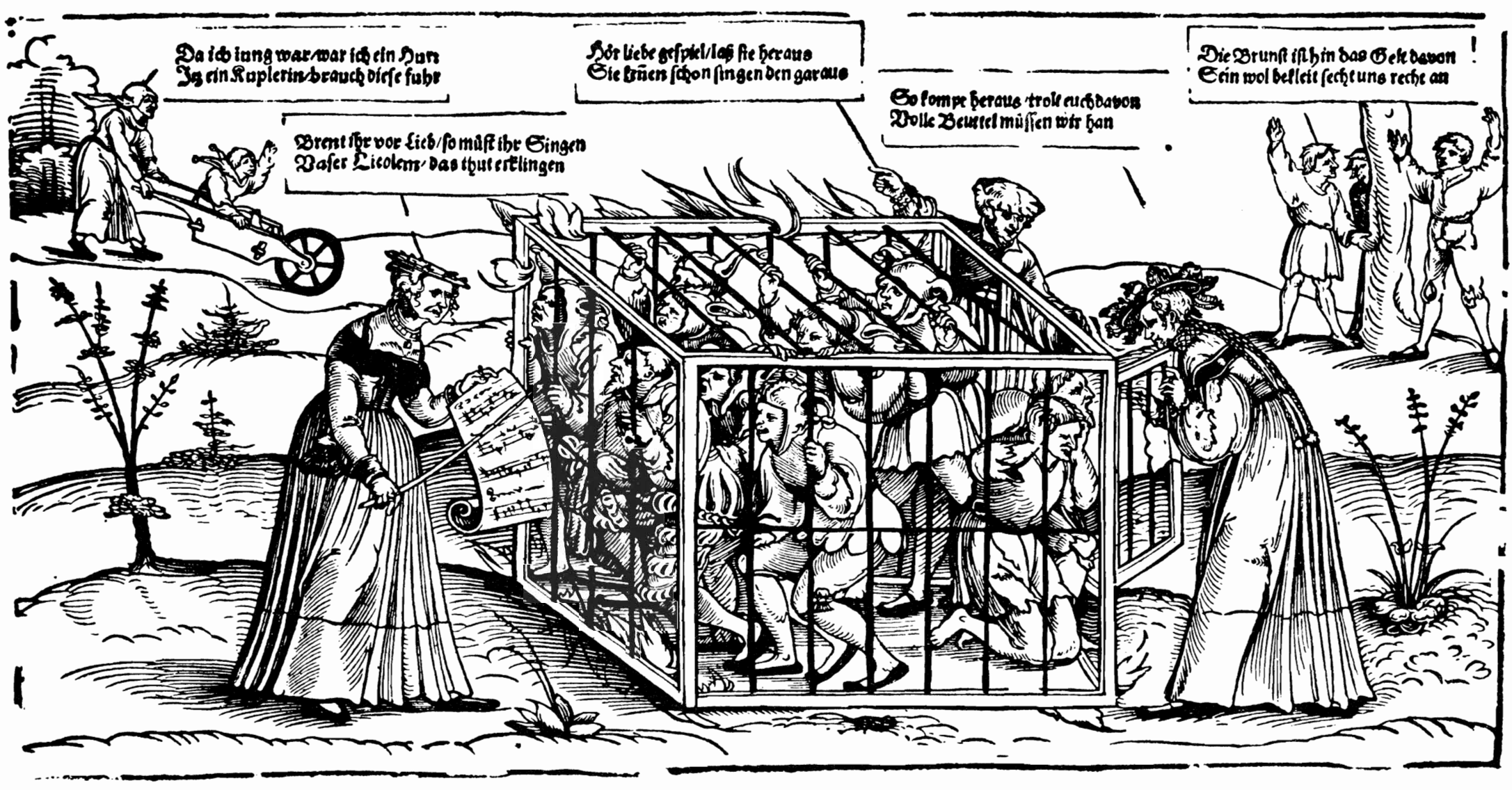


direction of the mercenary women who keep them there. For "full purses must we have," as the woman on the right intones.

But a last print, which we include here as much for its teasing obscurity as for its elucidative value, seems to show the opposite side of the coin, that is, the exploitation by men of women as sexual commodities. In The Horsemarket of Women (fig. 82), the viewer is confronted with the harshest definition of the dynamics of power in a human relation now become wholly exploitative, as men haggle with each other over the women they hold on leashes, even examining the mouth of one as if she were a horse.

This particular print is unusual. By and large it was woman who was presented as the culprit: woman as temptress was held accountable for the foibles of old men, or, if the old woman held the purse, it was her physical decrepitude that was the focus of the satirist. But whether woman or man was seen as the villian, and no matter what the particular inequality of a given Unequal Couple, the prints and paintings of Unequal Lovers offer a fascinating revelation of the psychology of a period in transition, for they suggest and document a process whereby the shifts in attitude that accompany social and political changes are confronted, examined and at last assimilated.

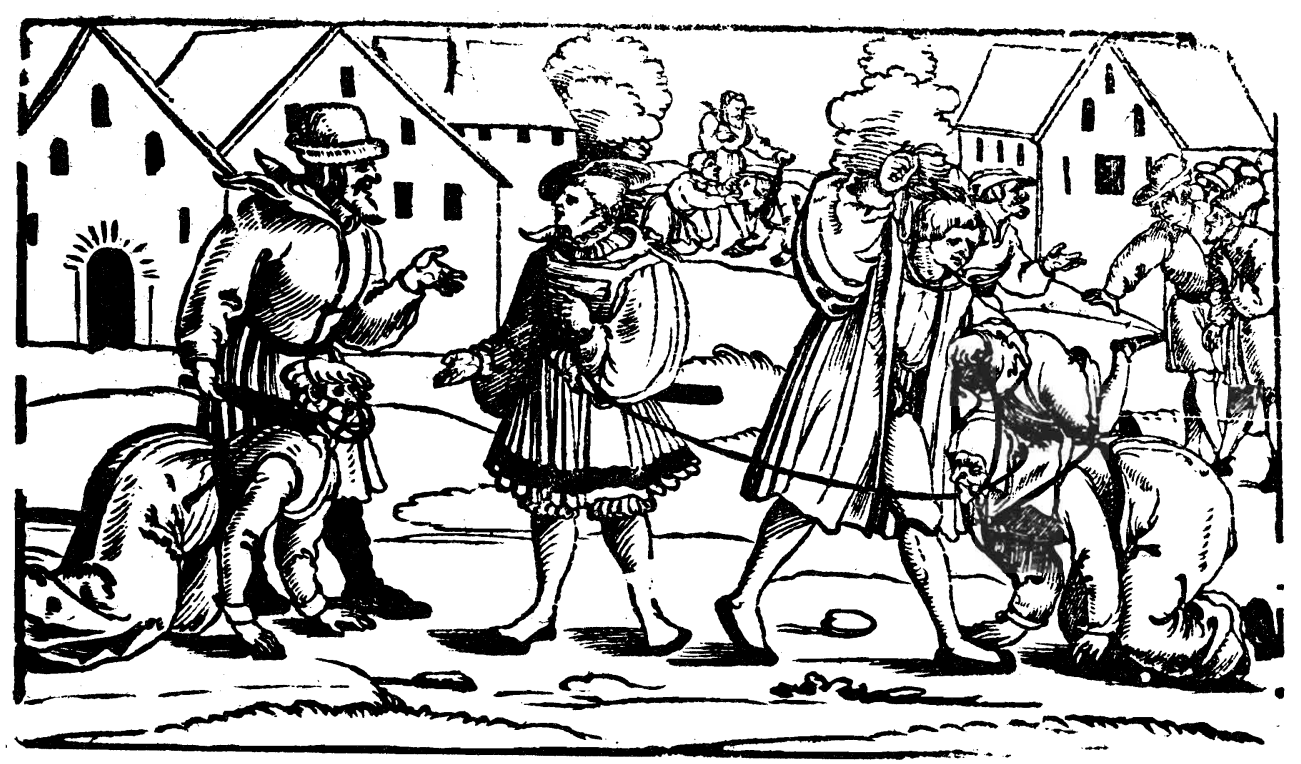

82. Anonymous, The Horsemarket of Women, ca. 1530, woodcut

81. Erhard Schőn, Cage of Fools, ca. 1530, woodcut 


\section{NOTES}

1. As cited in Robertson 1973, p. vii.

2. See Stith-Thompson, Motif-Index of Folk Literature, revised ed., Bloomington 1957, vol. 4, pp. 10, 39, 434; vol. 5, pp. 15, 51, 89, 150, 341, 345 and 348.

3. See Hasso von Winning, Pre-Columbian Art of Mexico and Central America, New York, n. d., pl. 441, for an illustration of a six-inch whistle described as Jaina, Campeche, Late Classic period. I would like to thank Dennis Joyce for bringing this unusual Unequal Couple to my attention.

4. See, for example, Wycherley's The Country Wife of 1675.

5. New York Post, 10 December 1975, p. 55.

6. Van Marle 1931-32, vol. 2, pp. 476-79, and figs. 487-92; Pigler 1974, vol. 2, pp. $568-70$.

7. Wescher 1938, pp. 376-79, and Silver 1974, pp. 104-23.

8. Coupe 1967, pp. 661-71.

9. The four plays are The Merchant, The Pot of Gold, The Casina, and The Comedy of Asses. In the last mentioned, a father helps his son to pay for a young courtesan and in the process falls in love with her himself; in the Pot of Gold, an old man, Megadorus, wishes to marry a miser's daughter. By the end of the comedy, however, she seems--since the conclusion has been lost (Duckworth 1966, vol. 1, p. 117)--to favor the old man's nephew, Lyconides, who has seduced her. In The Casina, old Lysidamus's attempt to sleep with one of his wife's young maids are thwarted through the joint efforts of the old man's wife and his son (who is in love with the same woman). See Duckworth 1966.

10. Duckworth 1966, vol. 1, pp. 277-319.

11. Haight 1965 , p. 3.

12. Kemp-Welch 1913, p. 32.

13. Ibid., pp. 29, 30, and 34 .

14. Ibid., p. 34.

15. See Mason 1924, pp. 125-36.

16. Ibid., p. 107.

17. De Lorris and de Meun, ed. 1962, p. xiii.

18. In an essay on "The Concept of Courtly Love," D. W. Robertson affirms that the Roman is "ironic and humorous," although he adds that "what is being" satirized. . . . is not 'courtly love' at all, but idolatrous passion"; Robertson 1973, p. 3.

19. De Lorris and de Meun, ed. 1962, pp. 99-101.

20. Randall 1966, p. 7.

21. Owst 1933, p. 377.

22. Randall 1957, p. 100.

23. Owst 1933, p. 381.

24. Ibid., pp. 224, 378-79.

25. Coulton 1910 , pp. 604,606 f.

26. See Komroff 1928, p. xi, and Randall 1957, p. 99.

27. See Swan 1905; and Grässe 1924.

28. Kalff 1889, pp. 211, 289-91.

29. Von Fallersleben 1838, pp. 90-99, and Leendertz 1907, pp. 91-97. I would like to thank Keith Moxey for bringing this work to my attention.

30. Boccaccio, ed. 1973, pp. 220-30.

31. Dempster 1941, p. 341.

32. Boccaccio, ed. 1973, pp. 568-79. See also "Second Day, Tenth Story," p. 18 above.

33. Chaucer, ed. 1964, pp. 243-57.

34. Taylor [1930], pp. ix, $\mathbf{x}$. 
35. Some are illustrated in Kurth 1963, figs. 36-48; all are reproduced in Kautzsch 1903.

36. See Talbot 1971, p. 113, n. 1 .

37. Taylor [1930] p. 107.

38. Ibid., p. 108.

39. Chapter 70. Ibid., pp. 132-34. For the illustration of this story by Dürer, see Kurth 1963, fig. 44.

40. Taylor [1930] p. 88.

41. Dempster 1941, pp. 333, 336.

42. Ibid., p. 336.

43. Ibid., 336-40.

44. Ibid., p. 343.

45. See Dempster 1941, pp. 343-47, for an excerpted version of the story; Holthausen 1910-11, pp. 170-76, for a more complete account; and von Keller 1855 , pp. 298-305, for the entire story.

46. The manuscript is in Stockholm, Royal Library. See Dempster 1941, pp. 347-50.

47. Ibid., pp. 354-55.

48. Ibid., p. 350 , n. 3 .

49. Ibid., p. 352.

50. Ibid., p. $354 \mathrm{ff}$.

51. Ibid., p. 341.

52. See von Keller 1853, pp. 700-3.

53. $\mathrm{Nu}$ ist sie junk, so ist er alt,

Und ist auch schwach und ungestalt

Und ist ain abgeritner gaul

Und ist des nachts im pett faul

Ibid., p. 700.

54. O Weibes List, wy manigfalt

Dein wunder sindt und dein gbalt

Am man, der deiner Thuck enpfindt! . . .

Dy Jungen wilden magstu zam,

Dy alten Thorem Im peutel lam.

The German text was cited by Anton Springer (1867, p. 186) though the above is from von Keller 1855, pp. 249 ff., and differs slightly from Springer's quotation of it.

55. Paris and Gevaert 1965, pp. 5 ff.

56. Fischer 1967, p. 318.

57. Ibid., p. 174.

58. Wardroper 1970, p. 2.

59. "Plautus," Der kleine Pauly Lexikon der Antike, ed. Konrat Ziegler and Walther Sontheimer, vol. 4, Miunich, 1972, p. 916.

60. Von Reinhardstoettner 1886 , vol. 1 p. 35.

61. Ibid., p. 33.

62. Ibid., p. 240 .

63. Bolgar 1963, p. 532. Bolgar lists translations of classical works into English, French, German, Italian and Spanish. The earliest Plautine translation was made by G. Berrardo in Italy in 1486; in Germany, Albrecht von Eyb translated Menaechmi and Bacchides in 1475, although they were not printed until 1511.

64. The manuscript is in Munich, Staatsbibliothek, Cod. lat: 14485. See Wiegand 1936, pp. $x$ and 3. The excluded works are Carmen de primordiis et fundatoribus coenobii Gandeshemensis and Vitae paparum SS. Anastasii et Innocentii, ibid., p. 42 .

65. For an illustration of two of these woodcuts, depicting Hroswitha presenting the book to Otto I, and Conrad Celtis presenting it to Frederick the Wise, see Kurth 1963, figs. 143 and 144. See also Grote et al. 1961, pp. 131-32. 
66. Wiegand 1936, p. xxii.

67. Coupe and Krailsheimer 1971, p. 495

68. Murner, ed. 1926, p. 6.

69. Brant, ed. 1962 , p. 33.

70. "Wer numpt ein wyb vum güt vnd gelt,/Der ist zu einem löffel zelt." Cited by Coupe 1967, p. 665; see also Murner, ed. 1926, p. 146.

71. Ob sy sunst gantz rotzig were, Grindig/lieff fol leüss/vnd schebig, Schellig/blint/vnsynnig, debig, Das schad ir nit, hett sy nur gelt, Bald spricht man, das sy wol gefelt. Hett sy zwelff ior an kruchen krochen Und den arss in falten gstochen: Noch is sy juh meyn keyseren ... Coupe 1967, p. 665.

72. Coupe and Krailsheimer 1971, p. 285.

73. "Yider den Ehebruch vnd di sünd der vnküscheit"; Goedeke 1856, p. 117.

74. Hastu vyl gulden in der täschen Die kan sie dir schon vssher näschen . . .

Sie sicht vyllicht mein seckel an Lat mich auch sein ir lieber man. Cited by Coupe 1967, p. 664, n. 2. See also Goedeke 1856, pp. 114 and 145.

75. Nun geths an die Alten grawen, die wil ich gürten bas.

wan sie kommen zu den frawen, so greiffens vmb den ars, sie richtens aus mit tasten, die frewlin sind vhn gram, O Alter Götz lass von tasten, het ich dein vollen kasten, ich seh dich nit mehr an ... Alter las von den weiben, magstu nimmer kegel scheiben, ich schenck dir der Kappen auch. Goedeke 1865, p. 413.

76. Thompson 1965 , vol. 1, p. 6.

77. Ibid., pp. 122, 123.

78. Ibid., p. 405.

79. Ibid., p. 403.

80. Thieme and Becker 1907-50, vol. 10, p. 609.

81. Ibid., vol. 35, p. 141.

82. "Eens Iongen mens auentuir/Dat is eens olden mans Vegevir." Bolte 1895, pp. 141-43.

83. Mijn Lief is ionck, ende ick bin oldt, Sie is seer heet, end ick bin coldt,

Hoer haer is geel, ende tmijn is graeuw, Hoer wangen sint root, de mijn sint blaeuw, ...

Daer om soe kijuen wij all den dach.

Ibid., p. 142. I would like to thank Keith Moxey for bringing these songs from the Antwerp Songbook to my attention.

84. Van Duyse 1905, vol. 2, pp. 938-39, no. 260. Other works from this edition of the Antwerp Songbook are cited by number in the text.

85. Bolte 1895 , p. 143.

86. Van Duyse 1905, vol. 2, p. 939, notes.

87. Hazlitt n. d., vol. 2, pp. 318-20.

88. Ibid., pp. 169-71.

89. Ibid., pp. 316-18. 
90. Ibid., p. 318.

91. Kalff 1889 , p. 293. I am again indebted to Keith Moxey for calling this work, as well as Eine Ehescheidung, cited in my n. 92, to my attention.

92. Fuchs 1909-10, vol. 1, pt. 2, pp. 28-29.

93. Der soll durch's Haar wohl langen,

Eine Weil stehn und danach hangen.

Neun Damen soll er den Läng nach haben, Das ist recht in Bayern und Schwaben.

Ibid., p. 30.

94. Goetze 1893, pp. 192, 113 , no. 34.

95. Bolte 1895 , p. 148 .

96. Ibid., p. 144, and Nijhoff 1933-36, vol. 2, pl. 318. I am grateful to Keith Moxey for referring me to this work.

97. Hutchinson 1966, pp. 73-78.

9.8. London, British Library, Add MS 49622.

99. For the connection between long hair and maidenhood throughout history and in German life and art about 1500, see pp. 94-97

100. Vienna, Oesterreichische Nationalbibliothek, Cod. 338f Ir. Martindale 1967, p. 246. See also Stange 1936, p. 47, and Schlosser 1893, p. 214. I would like to thank William Clark for calling this example to my attention.

101. Paris, Bibl. nat. fr. 282, fol. 345. Meiss 1974, pp. 62, and 444, n. 261.

102. Shestack 1967, commentary to fig. 72.

103. For a similarly dressed man in the Master of the Love Gardens' Small Love Garden, identified as a clerk, see Bliss 1928, p. 99.

104. For the associations between lust, dogs, and birds, see p. 81 and n. 195.

105. Kohlhaussen 1942 p. 168, observes that the Augsburg book printer othmar in 1512 replaced the word min by lieb, since the former term, by then antiquated, was taboo. It applied to indecent love, animals and whores. I would like to thank Christiane Andersson for suggesting this interpretation, made earlier by Kohlhaussen 1942, p. 168 and cited by Favis 1974, p. 235, n. 466.

106. The letter $n$ may have stood for Narrheit or foolishness, as the inclusion of four or possibly five fools in that letter suggests, especially since only one other fool is included in the rest of the alpahbet (in the letter $m$ ). It is interesting to note that in both cases folly is illustrated by scenes of the relations between the sexes; in the $n$ a monk is almost ridden à la Aristotle (see fig. 74), by a young woman who brandishes a switch. See Chapter 5 for a discussion of the Power of Women theme. Similar women are found in Israhel van Meckenem's Henpecked Husband (Lehrs 1969, fig. 649), or in his so-called Angry Wife engraving (Shestack 1967-68, fig. 238); In both, the woman raises her distaff as if she is about to clobber her mate. See also 'Master bxg's Henpecked Husband (Lehrs 1969, fig. 533), in the two figures, especially the woman, have become much older. The sexual power of women is extended also to old women in an engraving by Master b g (Hutchinson 1972, fig. 106), where one, who holds a branch or switch, rides in a low cart pushed by a bearded old man.

107. Maeterlinck 1901, p. 74.

108. Berlin, Staatsbibliothek Preussischer Kulturbesitz, on loan from Breslau, Biblioteka Uniwersytecka, Poland, ms. 2, 2 fol. 244r.

109. For the possible association of mush, bread, lust and appetite, see pp. 51-52.

110. Shestack 1967-68, assigns the date in his commentary preceding no. 29. Master E.S. also depicted men's genitals exposed by their women companions.

See Geisberg 1924, vol. 3 pl. 158

111. Favis $19 \% 4$, p. 176.

112. Shestack 1967, fig. 17 and my n. 188.

113. See Kunzle 1973, p. 14.

114. Muther 1972, p. 332. pl. 28, and Schramm 1920-43, vol. 4: Die Drucke von Anton Sorg in Augsburg, pl. 54, fig. 394.

115. Wittenberg, Lutherhalle. 
116. Basel, Kupferstichkabinett, Kunstmuseum.

117. "Un minem seil ich drafter jeich/vil narren, affen, esel, geuch/die ich verfür betrü und leich." Goedecke 1872, p. 26. The earlier engraving (fig. 22) is glued into an Augsburg manuscript located in Munich, Staatsbibliothek (Clm. 3941, fol. 139v.).

118. Brant, ed. 1962, pp. 88-91. Goedeke 1872, pp. 26-29, cites the German:

Frou Venus mit dem ströen ars

bin ich die minst im narrenfars; ich züch zü mir der narren vil und mach ein gouch uss wem ich wil, ... wen trift Cupido, den enzint Amor, sin brüder, das er brint und mag nit leschen wol die flam, die Didoni ir leben nam ...

David liess weschen Bersabe; Samson vertrut nit Dalide; der wis man als ein ross nit ging; am thụrn Virgilius nit hing; . . . wer mit frouen hat vil credenss, dem würt verbrent sin conscienss; und mag gänzlich nit dienen got, wer mit in vil zü schaffen hat. . . doch vil schäntlicher ist sie dan, so bülen dünt alt wib und man. . . . dan das man wisheit pfleg und bül, mag ganz nit ston in einem stül. ein büler würt berblendt so gar; er meint, es näm nieman sin war; diss ist das kreftigst narrenkrut, diss kappen kläbt lang an der hut.

119. Robertson 1973, p. 199.

120. See Huizinga 1954, p. 114.

121. Capellanus, ed. 1959, p. 20, and Robertson 1973, pp. 392, 393.

122. Ibid., pp. 393f.

123. Ibid., pp. 399, 401.

124. Hollstein 1949-74, vol. 13, p. 61; see also Lebeer 1939-40, p. 193.

125. "En Vuilt myn Hinneken/Niet Te Seer Genaeken/Het Soude lichtelyck Aen De Sprou Geraeken."

126. "Siet hoe den ouden voelt het hoen,/Een droge Queen wil oock wat doen." Hollstein 1949-74, vol. 2, p. 81. For a discussion of birds as a symbol of lust, see pp. 53-54.

127. Brant, ed. 1962, p. 70. Goedeke 1872, pp. 13, 14, cites the German: Min narrheit losst mich nit sin gris; ich bin fast alt, doch ganz unwis, ein bösses kint von hundert jor, den jungen trag ich dschellen vor.... Alter will ganz kein wiss me han. Susannen richter zeigten wol was man eim alten truen sol.

128. Lehrs 1908-34, vol. 8, p. 206, mentions an old woodcut with a dancing fool and an old woman. He also cites an etching by Daniel Hopfer (B. 72 ) that is inscribed above "Bolikana Markolfus," with a poem at the bottom. if Marcolf and Polikana hadn't been so foolish, it points out, they would have been forgotten long ago:

Der Tugent Lieb und Thorheit übung macht, Das offt noch spatt an manchen wird gedacht 
Der seinen Lauff schon längsten hat vollbracht

Marcolphus den die würmer längst gefressen,

Sambt seinem Weib wer Tausendmahl vergessen,

Hätt ihr gehirn die Thorheit nicht besessen.

I would like to thank Lotte Brand Philip for her translation of this passage.

129. "Ich frest und full den bauch mit brey/und eben Mager Bleib dabey." I would like to thank Christiane Anderszon for calling this engraving to my attention and for suggesting this interpretation.

130. Kratz 1949, vol. 1, pp. 96-103, especially p. 103, where a man who neglects his wife for another leaves the former "ungegessen" or uneaten.

131. Lipperheide 1907, p. 920.

132. Brant, 1962 ed., p. 97.

133 The barrel or tub ("Fass"), a utilitarian object related in shape to the jug, was used in the late Middle Ages in German as a metaphor for the female genitals. Adultery was committed therefore when someone drank from another's tub ("aus dem Fasz eines anderen trinken"). See Kratz 1949, vol. 1 , pp. 60, 62.

134. Vienna, Kunsthistorisches Museum. Illustrated Tietze-Conrat 1957, p. 59, fig. 65 .

135. Lehrs 1969, fig. 532.

136. For further discussion of birds and lust, see p. 81, and n. 195.

137. See von Keller 1853, p. 156, cited by Kratz 1949, vol. 2, p. 91.

138. Brant, ed. 1962, p. 139. Goedeke 1872, pp. 63, 64, cites the German: die welt steckt vol beschiss und list ....

Wäger ein schmirzler in sim hüss, dan brüten frömde eier uss.

Wer vil uss fliegen wil zü wald, der wurt zü einer grasmuck bald; wer brennend kol in gören leit und schlangen in sim büsen treit und in sinr teschen zücht ein mussolch gest lont wenig nuss im hus. In the German of the time the word for nest ("Nest") indicated the female genital, and eggs ("Eier") the testicles; Kratz 1949, vol. 1, pp. 67, 90 , and 91 .

139. "My ma syn eyere ontlaeyt/Jees aders nest e laet my ot paeyt."

140. Maeterlinck 1901, p. 192; Hollstein 1949-74, vol. 11, p. 199.

141. Tietze-Conrat 1957, p. 7.

142. See Brant, ed. 1962, pp. 8 ff.

143. Willeford 1969, pp. 11, 85.

144. Koslow 1975, p. 421.

145. Stuttgart, Staatsgalerie and Strasbourg, Musée des Beaux-Arts.

146. "Set ale her czo wor Ich disse rose hin do" and "Scham dich dorin." The engraving is glued into the front cover of ms. Cgm. 403 in the Staatsbibliothek, Munich.

147. Cats, apes and lapdogs were common pets , f courtesans, according to Tomaso Garzoni in his La piazza universale di tuı e le professioni. . ., published in Venice in 1595. Cited by Janson 1952, p. 278, n. 16.

148. Hans Joachim Mähl, in his notes for an edition of Brant's Das Narrenschiff (1964, p. 185, n. 1), observes that "flaying a donkey for its fat" is a proverbial expression for "behaving foolishly," as is the similar "desirirg to milk mead from an ass." Brant's German reads:

Wer durch kein ander ursach me, dan durch güts willen, grift zür e, der hat vil zanks, leid, hader, we.

Goedeke 1872, p. 94 
149. Brant, ed. 1962, pp. 182f. Goedeke 1872, p. 94, cites the German:

Wer schlüft in esel um das schmär, der ist vernunft und wisheit lär, das er ein alt wib nimt zür e ein güten tag und keinen me. Er hat ouch wenig freüd dar von, kein frucht mag im daruss enston und het ouch niemer güten tak, dan so er sicht den pfeningsak.

150. Groningen, Museum van Oudheden.

151. Steinbart 1929, p. 220.

152. Tietze-Conrat 1957 , p. 85 , discusses this generally accepted meaning of the gesture.

153. Brant, ed. 1962, p. 372, n. 1, under chapter 33.

154. For the passage, see ibid., p. 136. Goedeke 1872, p. 33, cites the German: Wer durch die finger sehen kan und losst sin frou eim andern man, do lacht die katz die müs süss an.

155. Röhrich 1973, vol. 1, p. 167, and George Marlier 1954, p. 236.

156. Ibid., p. 236.

157. Steinbart 1929 , p. 220.

158. Author's translation. "My good graces!" refers to Dame Folly.

159. Erasmus of Rotterdam, ed. 1971, Radice and Levi, pp. 141, 142.

160. Ibid., p. 87.

161. Ibid., pp. 82, 83. See also pp. 55, 106.

162. Base], Kupferstichkabinett, Kunstmuseum.

163. Willeford 1969, p. 10.

164. Strauss 1977, pp. 71-73.

165. Slatkes 1976, p. 151.

166. London, British Library. For an illustration see Rosenberg 1923, pl. 46. I would like to thank Christiane Andersson for calling this drawing to my attention.

167. Washington, National Gallery.

168. Shestack 1967-68, intro. to nos. 233-43, dates the Meckenem around 1495-1503. For an illustration of the latter, see Warburg 1930, pl. 27.

169. Castagnola, Thyssen-Bornesmisza Collection, Schloss Rohoncz.

170. Erasmus of Rotterdam, ed. 1971, Radice and Levi, p. 89. Silver 1974, p. 119 , cites this passage in a different version.

171. Jacques Lavalleye 1967, p. 21.

172. Ibid., p. 117, where the original Dutch is cited in rote 40 .

173. Jacques Lavalleye 1967, p. 21.

174. Silver 1974, pp. $111 \mathrm{f}$.

175. Röhrich 1973, vol. 1, p. 434, and Tolnay, n.d., p. 68.

176. "Cockold," The Oxford English Dictionary, vol. 5, Oxford, 1933, p. 385, def. $7 \mathrm{~b}$.

177. Hind 1938-48, vol. 2, pl. 108. See vol. 1, pp. 73 ff., for a discussion of the plate.

178. "I miciamo . in chopa . eldifetto . none . mio"; ibid., vol. 1, p. 73, no. 23, cites the inscriptions and their translations as referred to here and below.

179. "Glie . piu . chmibebechacci."

180. "Chinone . morto . morira . cnonone . becho . vengiira."

181. Gelt und gütz gnung wil ich dir geben

wiltu nach meinen willen leben

Gievst mitter hannde in meinen tasschen

Des sloss will ich diss auch erlassen 
Es hilft kain sloss fur frauwen list kain treu mag sein dar lieb nit ist Darumb ain slussel der mir gefelt Den wol ich kaüffen umb dein gelt

Ich drag ain slüssel zu solliche stoffen wie sol es manchen hat verdrossen Der hat der narrenkappen fill Der rechte lieb erkaüffen will.

182. Röhrich 1973, vol. 2, p. 862, cites a Prussian expression, "He turned the key" ("Er hat sich den Schlüssel verdreht"), meaning "He contracted syphillis" ("Er hat die Syphillis bekommen").

183. Brant, ed. 1962, pp. 134f. Goedeke 1872, pp. 59f., cites the German: Vil narrentag, und selten güt hat, wer sinr frouen hüten důt; dan welch wol wil, die dủt selb recht, welch übel wil, die macht bald schlecht, wie sie $\mathrm{zu}$ wegen bring all 'tag ir böss fürnemen und anschlag. leit man ein malschloss schon dafür und bschlüsst all rigel, tor und tür und sesst ins hus der hüter vil, so gat es dennaht, als es wil. was half der turn drin Danä ging darfür, do sie ein kind entpfing.

184. Fielding 1942, pp. 149-50.

185. Fischart's Gargantua was printed in 1575, 1582 and 1590; Coupe and Krailsheimer 1971, pp. 151 and 355.

186. Veste Coburg, Kunstsammlungen. Davis (1975, fig. 10) dates the drawing and attributes it to the Petrarca Master as does the museum. Würtenberger (1957, pl. X ill. 20) assigns it to Hans Leu.

187. Stockholm, National Museum.

188. David Dalby (Lexicon of the Medieval German Hunt, Berlin, 1965, pp. xxiii-xxv) includes seventeen literary examples of the hunt as an allegory of love, dating from the thirteenth through the end of the fifteenth centuries. Two fourteenth-century examples are especially relevant to this study; one refers in didactic and satirical fashion to the social and political situation in Austria at the end of the century; the other is an obscene allegory of the hunt entitled Die Brackenjagd.

189. See above, p. 52.

190. Göthe (1887, no. 258 ) identifies the coins on the table near her scales as Spanish and French, the significance of which he does not mention.

191. See above p. 54 , and note 195 . The article is by Jongh; 1968-9.

192. Grimm 1854-1971, vol. 12, pt. 2, pp. 433 (def. 5) and 430.

193. Nuremberg, Germanisches Nationalmuseum. The other painting was formerly located in Lucerne, Fischer Gallery.

194. Efforts to locate the variant of the Nuremberg painting have been unsuccesful. A photograph of it is located in the Bayerische Staatsgemäldesammlungen, Munich, where its most recent location is listed as Lucerne, Fischer Gallery. Unfortunately that gallery, which also attributed the work to Lucas Cranach the Younger, can offer no information concerning the painting's location other than its having been in their possession around 1970. For a very poor illustration, see Fuchs 1912-28, vol. 1, fig. 47.

195. Favis 1974, p. 114. In addition Koepplin and Falk 1974-76, vol. 2, p. 574, state that the partridges and swans in the background of Cranach's Samson and Delilah of 1529 (Augsburg, Städtische Kunstsanmmlungen) are probably 
symbols of lust, as are the partridges in his Resting Fountain Nymphs (Private Collection and Darmstadt, Hessisches Landesmuseum) of ca. 1526 and 1533. For illustrations see Koepplin and Falk, pp. 571 and 637. The association of water birds with lust may be directly related to the long hystory-going back to antiquity-of seafood and the water-related as erotic or aphrodisiac. The source is probably Venus's legendary birth from the foam of the sea.

196. Wind 1972, p. 43. His reference to Emil Mâle's L'Art religieux de XIII ${ }^{e}$ siecle en France, Paris, 1902, p. 149, does not check out. Wind himself discusses Vincenzo Campi's Cheese Eaters (Lyons, Musée des Beaux-Arts; his fig. 17) painted in the 1580 s. There, three men who represent youth, middle age and old age eat cheese as an old bawd watches from the right. Wind believes that the cheese-folly association passed into the Renaissance from the later Middle Ages.

197. Berlin, Kupferstichkabinett.

198. Basel, Kupferstichkabinett, Inv. U. VII. 55. See Favis 1974, pp. 99 and $151 \mathrm{f}$., n. 221, for a number of examples, including a Rhenish mural decoration of 1451 depicting an engaged couple, in which the man presents the woman with a ring and she raises her skirt (illustrated Clemen 1930, p. 321, fig. 329). More famous examples include the month of April from the Très Riches Heures, Robert Campin's Marriage of the Virgin, Jan van Ey'ck's Arnolfini Wedding and Rogier van der Weyden's matrimonial scene in his Seven Sacraments. For illustrations, see Panofsky 1971, vol. 2, figs. 91 and 95 (detail), 199, 247, and 349.

199. Janson 1952, p. 83. Fritz Saxl 1942, p. 140, cites two examples of the German moral encyclopedia, a compendium of moral allegories. The copies are located in Rome, Biblioteca Casantense, and in London, Wellcome Museum, and dated by Saxl from the second quarter of the fifteenth century.

200. Hoffmann-Krayer and Bächtold-Stäubli 1927-42, vol. 5, pp. 411-13.

201. Hutchinson 1972, p. 53.

202. Hoffman-Krayer and Bächtold-Stäubli 1927-42, vol. 5, p. 413, and Kratz 1949, vol. 2, p. $440 \mathrm{ff}$.

203. It is interesting to note that both Dürer's woodcut and the accompanying text may have derived ultimately from the activities and plays of the carnival, for it was during the pre-Lenten festivity of the carnival that the custom of making green nosegays or garlands was adopted.

204. Hoffmann-Krayer and Bächtold-Stäubli 1927-42, vol. 5, p. 411.

205. Ich liess von perlen und gestein (edelstein)

ein schönen kranz ir machen ein,

den setz si uf, die zart und rein.

Grimms 1854-1971, vol. 5, p. 2051.

206. The Krodel Unequal Couple is in New York, Ira Spanierman Gallery. A painting very similar to the Krodel is Cranach's betrothal portrait of Herr von Rava (Art Museum in Sao Paolo) of 1539; illustrated Wolffhardt 1954, p. 192. Wolffhardt also cites Hans von Kulmbach's 1511 Margrave Casimir von Brandenburg-Kulmbach (Munich, Alte Pinakothek) and Cranach's Duke Henry the Pious of 1514 (Dresden, Gemäldegalerie). The latter wears a very wide garland that also includes white carnations. For illustrations see Franz Stadler 1936, pl. 19, fig. 47, and Friedländer and Rosenberg 1932, fig. 53. Stadler (p. 113) states, however, that the garland here has nothing to do with Casimir's long engagement, nor, in the case of Duke Henry, is it related to engagement, since the work is dated 1514 and the sitter had been married since 1512 . Cranach is said to have utilized the carnation garland in prtraits of royalty who had long been married.

207. Wolffhardt 1954 , p. 190. 
208. Hanns Bächtold 1914, p. 174.

209. Tervarent 1958, p. 129. See also Hoffmann-Krayer and Bächtold-Stäubli 1927-42, vol. 5, p. 387.

210. Tervarent 1958, vol. 1, p. 128, gives this definition (luxury) for a crown of flowers, citing a series of sixteenth-century Brussels tapestries in Madrid, Museo Nazionale.

211. Sumberg 1941, p. 157.

212. Philadelphia, John G. Johnson Collection.

213. Illustrated Panofsky 1971a fig. 207.

214. Klibansky, Panofsky and Saxl 1964, p. 325, pl. 1.

215. The Egyptians and ancient Britons tied up the bride's hair after the wedding ceremony, possibly as a symbol of the submission that the marital state was supposed to bring, while the ancients commonly cut the hair of newly-married women, essentially to reduce their sex appeal and attractiveness. Fielding 1942, p. 34 .

216. Hoffmann-Krayer and Bächtold-Stäubli 1927-42, vol. 5, p. 415, def. 15.

217. Thompson 1965, vol. 1, p. 113.

218. Illustrated Hollstein 1954ff., vol. 5, pp. 98, 99; and Diedrichs 1908, vol. 1, fig. 590.

219. New York, Pierpont Morgan Library. Illustrated Medieval and Renaissance Manuscripts. Major Acquisitions of the Pierpont Morgan Library 1924-74, New York, no. 50. I would like to thank Bill Voelkle for calling this illustration to my attention.

220. See Handlist no. 56.

"Hye sytzet des Endcrist vatter würbt vmb syn lyplich toch/ter in üppichkeit.die im der werck verwyiliget Vnnd empfachet von irem eygen vatter den anthycrist."

221. “DISCITE.A.ME.QVIA.NEQVAM.SV./.ET.PESSIMO CORDE.1502”,

222. "Bedēk das end das ist mein rot: Wañ alle ding beschlusst der todt." "Ye glych und glych geselt sich gern. Drum wil ich mich zu diesem kern." Schreiber $1926-30$, p. 115 , no. 1978 , cites this additional inscription not included in fig. 6 , but gives no location for it.

223. See Favis 1974, chapter 4, pp. 195-228, and Wulff 1914, passim.

224. White 1976 , p. 8. I would like to thank Keith Moxey, who sponsored the graduate paper on Unequal Lovers at the University of Virginia, and Lynda White, the author. Her study proved especially provocative for the sociology of Unequal Lovers and formed the basis for many of the ideas discussed in this chapter.

225. See ibid., p. 32, n. 12. See also Jackson 1968, pp. 55-76.

226. Favis 1974 (p. 298) identifies the tapestry as fifteenth-century Rhenish, though her apparent source (Kohlhaussen 1942, p. 152, fig. 5) cites the work as Franconian ca. 1400-20.

227. Favis 1974 (p.209) again identifies the tapestry as fifteenth-century Rhenish, though her apparent source (Kohlhaussen 1942, p. 151) calls it Alsatian ca. 1380. She also identifies the old and young man as such (p. 183).

228 Engelbert Kirschbaum, ed. 1971. Lexikon der Christlichen Ikonographie, vol. 3, Rome, Freiburg, Basel and Vienna, col. 269.

229. "LAS MICH I FRID DV ALTS KAFAL" and "Heintz und narr genent pin ich/All welt tut yetzundt fatzen mich." The manuscript into which the woodcut is pasted is found in the Bayerische Staatsbibliothek, Munich, no. TK. The latter inscription is quoted from von Keller 1858, p. 325, and referred to by Springer 1867 , p. 206.

230. Herlihy 1975 , pp. 10-11.

231. Ibid., p. 13.

232. Ibid., p. 12, Bücher 1910, pp. 3, 6, and 9. See Gilbert 1967, pp. 7ff., for a discussion of the Renaissance conception of old age. 
233. Rörig 1967, pp. 112, 115, 116. The figures are from about 1400 .

234. Von Andlaw 1861, p. 199.

235. Veit [ 1969 ], commentary to plate v.

236. Schabacker 1972, p. 378.

237. Kühn 1968, pp. 7 and 9.

238. See Capellanus, ed. 1959, pp. 44-68, 84-106.

239. See Beeh 1966, pp. 53-82, and Schramm 1920-43, vol. 4, p. 51 and figs.

756-68; vol. 19, pp. 11, 15, and figs. 776-91. I would like to thank Christiane Andersson for bringing the article by Beeh to my attention.

240. Capellanus, ed. 1959, pp. 39f. See Beeh 1966, p. 76, fig. 2, for the manuscript illumination, although the accompanying young man and old woman (fig. 3) are not described by Capellanus.

241. Sachs 1971, pp. $20 \mathrm{f}$.

242. Janson 1952, p. 262, and fig. 20, p. 263.

243. Douai, Museum. The attribution to Jan Massys is questionable (see handlist 20).

244. Favis 1974 , p. 226.

245. Ibid., p. 226.

246. See Swain 1969, pp. 1-4.

247. Natalie Zemon Davis has offered related suggestions concerning role reversals in comedy and festivity in early modern Europe. See Davis 1975, p. 131.

248. Swain 1969, pp. 12 , and 189, n.2.

249. Ruhmer 1963, p. 20, commenting on Cranach's numerous representations of the theme, writes that they are

sometimes sheer comedy. Their underlying irony

is reminiscent of Shakespeare or Hogarth without the latter's moralizing pathos. Cranach neither complains nor seeks to educate-he shows himself full of good-humoured understanding.

250. Lehrs 1969 , p. 360.

251. See Geisberg 1924, vol. 2, plates $149-158$ and 167 , which illustrate engravings ranging from the suggestive to the obvious. For example, a woman holds a man's gown flap (pl. 149); a young man touches his own suggestively-placed dagger (pl. 150); or, more blatantly, a fool's penis is exposed by a woman who pulls back his gown (pl. 158); and another fool holds up a young woman's skirt, thereby exposing her stubbled genitals (pl. 167).

252. Munich, Alte Pinakothek and Vienna, Kunsthistorisches Museum, respectively. For illustrations, see Winzinger 1975, plates 55 and 49; and Ruhmer 1965, figs. 150,141 , and 142 .

253. Regensburg, Städtisches Museum and Budapest, Szépmüveszéti Muzeum. Illustrated Winzinger 1975, plates 80-89, and Ruhmer 1965, fig. 154.

254. Illustrated Hollstein, 1954ff., vol. 3, p. 93.

255. Von der Osten and Vey 1969, p. 233.

256. Hollstein 1954ff., vol. 3, pp. 50-58, 73.

257. Harbison 1969 , p. 30 , stresses the exploitation of this subject specifically for the change in the depiction of the female nude.

258. Illustrated Holkstein 1954ff., vol. 3, p. 45. See ibid., pp. 166-289, for illustrations of H. S. Beham's woodcuts.

259. For a discussion of the themes, see Hutchison 1966, pp. 73f., and Kahr 1972, pp. 282-99.

260. The earliest is a copy after a lost work by the Housebook Master; a woman rides a man in the Topsy-Turvy World dating from the 1480s (Shestack 196768, no. 206). Another depicts a wife literally wearing her husband's pants (Lehrs 1969, fig. 63), while the third and latest, ca. 1495-1503, shows the devil-possibly a false demon with an equally false threat, like that found in a few Unequal Lovers-aiding the wife, who commands not only her husband but also his pants (Shestack 1967-68, no. 238, and Lehrs 1969, fig. 649). 
261. For some illustrations of woodcut representations, see Kahr 1972.

262. Campbell 1976, p. 189. I wish to thank Mark Zucker for bringing this article to my attention,

263. See the Handlist, no. 8 pertinent information known to me, including Ulrich Bart's descrip-

264. Thieme and Becker 1907-50, vol. 2, p. 461.

265. Waetzoldt n.d., p. 8. See Rupprich 1956-69, vol. 1, p. 244, for the Jacob Arnoldt document of 1500. Dürer had already hired Konrad Schweitzer in 1497 to sell his engravings and woodcuts from region to region and city to city; ibid., vol. 3, p. 448. Strauss 1974, p. ix, suggests that Agnes sold only Dürer's devotional prints at the Nuremberg market square, while Fedja Anzelewsky 1970, p. 5, states that it has been recorded that Agnes sold both her husband's woodcuts and engravings - and thus possibly secular subjects alsostanding at a market stall. This implies that Agnes was working in Nuremberg, where she and her husband lived.

266. Talbot 1971, p. 14. Dürer sent 200 and 500 impressions to Cardinal Albrecht of Brandenburg for two engraved portraits of him.

267. Ibid., p. 15

268. Lotte Brand Philip, private communication.

269. Hutchison 1966, p. 77.

270. Bialostocki 1967, p. 28

271. See Silver 1974, pp. 122f.

272. Koepplin and Falk 1974-76, vol. 2, p. 562.

273. Möller 1928, p. 154.

274. Urzidil 1942, pp. 20, 30, 37f., and 48.

275. Pedretti 1964, p. 80 .

276. Koepplin and Falk 1974-76, vol. 1, p. 214, and vol. 2, p. 568.

277. Sumberg 1941, p. 78, n. 130.

278. Hutchison 1972, p. 12. For illustrations, see ibid., p. 128, fig. 46, and p. 131, fig. 50; Bossert and Storck 1912, pl. 2.

279. Friedländer and Rosenberg 1932 , p. 55 , no. 132 , Ruhmer 1963, p. 86 , and Friedländer 1947, p. 116.

280. I would like to thank Lotte Brand Philip for bringing this painting to my attention.

281. Margaretta Salinger 1960, "Baldung-Grien," Encyclopedia of World Art, vol. 2, New York, Toronto and London, cols. 205f.; Otto Fischer 1951, Geschichte der deutschen Zeichnung und Graphik, Deutsche Kunstgeschichte, vol. 4, Munich, p. 337; R. W. Scheller 1963, A Survey of Medieval Model Books, Haarlem, pp. 214f. See also Christiane L. Joost-Gaugier 1973, "Subject or Nonsubject" in a Drawing by Jacopo Bellini. Commentari 29: 148-53.

282. I would like to thank Christiane Andersson for making this drawing and perinent information about it known to me, including Ulrich Bart's description of it as a typical goldsmith drawing.

283. Von der Osten and Vey 1969, p. 215.

284. For the woman in profile and the five grotesque men, both in Windsor (12447R and 12495R), see Clark and Pedretti 1968, vol. 2, figs. $12447 \mathrm{r}$ and 12495r; vol. 1, p. 73, dates the drawing of the woman in profile to ca. 1491 and Pedretti 1957, p. 33, to ca. 1492. The Five Grotesques are placed around the same time-ca. 1490 by Popham (1945, p. 42) and ca. 1494 by Clark and

Pedretti (1968, vol. 1, p. 85). For interpetation and a copy after the Five Grotesques, see Gombrich 1976, p. 71 (and fig. 183), and Bialostscki 1959, pl. 4.

285. Larsen 1950, p. 174, and Krönig 1950, pp. 174, and 10f., n. 24.

286. Major and Gradmann [1942], p. 21, no. 38, and fig. 38. 


\section{HANDLIST}


This handlist is divided into three main sections to facilitate locating and studying representations of Unequal Love. The first division, "Half-Length Unequal Couples," includes those prints and paintings that consist of an embracing unequal couple in approximate half length before a neutral ground; some examples from the next section are included here for comparative purposes. "Expanded Unequal Couples" comprises all other representations of unequal couples, including a small number with more than one unequal couple, and those in full length, often with backgrounds or settings that suggest the outdoors. Demons, animals, and putti are also included, and greater attention is paid to genre-like details, such as fruit or card games. "Love Triangles" are depictions of an old man giving money to a young woman who passes it to her young lover (the sequence is usually left to right: old man, young woman, young man). An additional section is appended for questionable representations.

The organization is both chronological and formal. A purely chronological arrangement is impossible due to the paucity of dates on the many works by Cranach and school and it is hoped that the formal arrangement will illuminate the few types and many variations employed by that circle. If two paintings are near copies and only one is dated, for example, the undated variant is placed after the dated. Similarly, if a painting of 1530 has a variant of 1540 , the latter would be placed directly after the earlier date, rather than among the works of 1540 . 


\section{HALF-LENGTH UNEQUAL COUPLES:}

\section{Old Man and Young Woman}

The Housebook Master (active ca. 1465-1505, Middle Rhine around Mainz)

Ca. 1472-75; drypoint; 101 x 91 mm. L.8.141.63; P.2.263. 55. Amsterdam, Rijksprentenkabinet (unique). Augustoni 1972, no. 74. Hutchison 1972, pp. 11, 12, places this drypoint at the end of the Housebook Master's early period (1465-75); p. 135, fig. 55. Lehrs [1894], fig. 55. See text fig. 14.
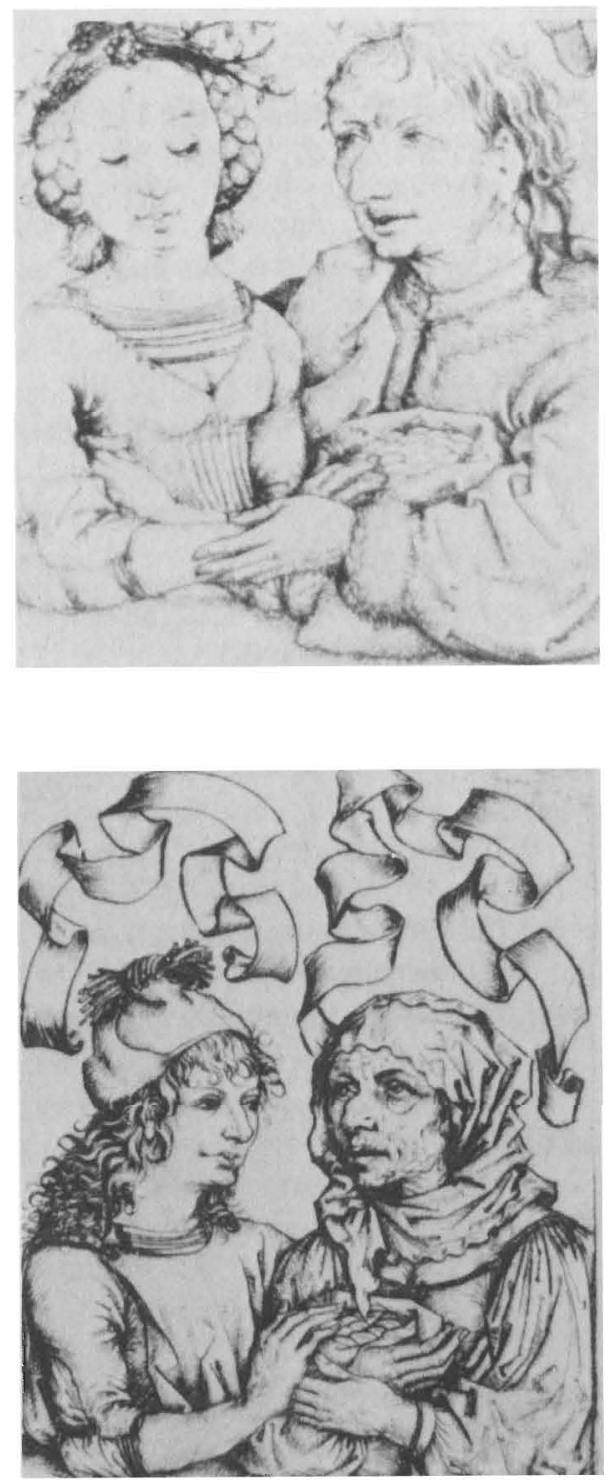

Old Woman and Young Man

The Housebook Master

Ca. 1475-78; drypoint; 125 x 97 mm. L.8.141.62; P.2.263.54. Amsterdam, Rijksprentenkabinet (unique). Augustoni 1972, no. 73. Hutchison 1972, pp. 11, 12, dates this drypoint at the beginning of the Housebook Master's mature period (1475-88); fig. 56. Lehrs [1894], fig. 56. See text fig. 80 .
Old Man and Young Woman (copy in reverse of no. 1)

Israhel van Meckenem (ca. 1445-1503, active Lower Rhine Valley, especially Bocholt and Cleve).

Ca. 1480/85-90; engraving; 147 x 114 mm. B.6.266.170; L.9.381.489; P.2.194.180. Silver 1974, p. 113, fig. 6.

Shestack 1967-68, assigns a date around 1480-90; fig. 208. Geisberg 1905, p. 189, dates the companion piece around 1485-90, suggesting a terminus post quem of 1485 for this engraving also; fig. 400 .

not illustrated 
Old Woman and Young Man (copy in reverse of no. 2) Israhel van Meckenem

Ca. 1485-90; engraving; 146 x 114 mm. B.6.266.169; L.9.381; P.2.194.169. Silver 1974, p. 112, fig. 5. Geisberg 1905, pp. 188, 189 (for dating see no. 3); fig. 399.

Old Woman and Young Man (after a Leonardo da Vinci drawing of the late 1490s)

Jacob Hoefnagel (1575-ca. 1630, active Vienna and Prague) 1602; drawing; 169 x $193 \mathrm{~mm}$. Vienna, Albertina. Silver 1974, p. 111; p. 117, fig. 10 . Suida 1929, p. 71, fig. 119; p. 101, for dating. Möller 1928, p. 153, fig. 214; pp. 15254, for the "vom Huknagel 1602" inscription on the back, which the author believes reflects an authentic signature and date originally on the front, and added to the verso when the sheet was.trimmed. See text frontispiece.
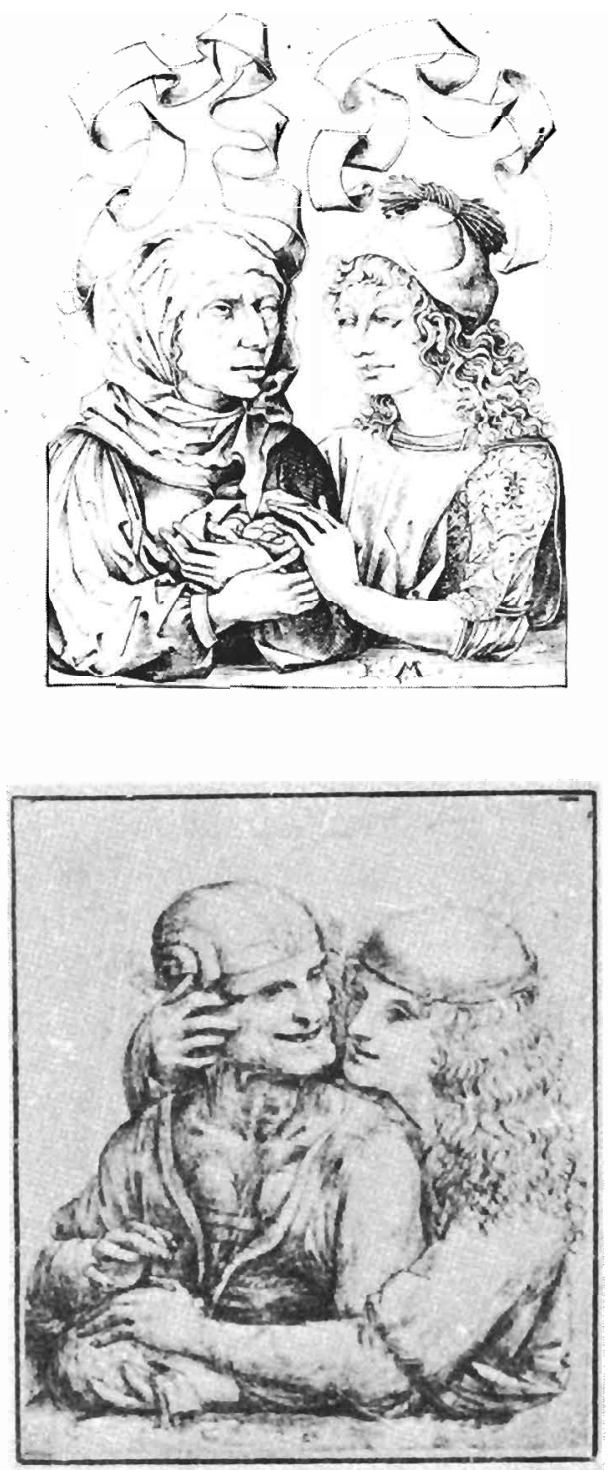

Old Woman and Young Man

Wnezel Hollar (1607-1677, Bohemian, active in England and Antwerp)

1646; etching; 170 x 132 mm. Koepplin and Falk 197476, vol. 2, p. 569, no. 464. Möller 1928, fig. 216.

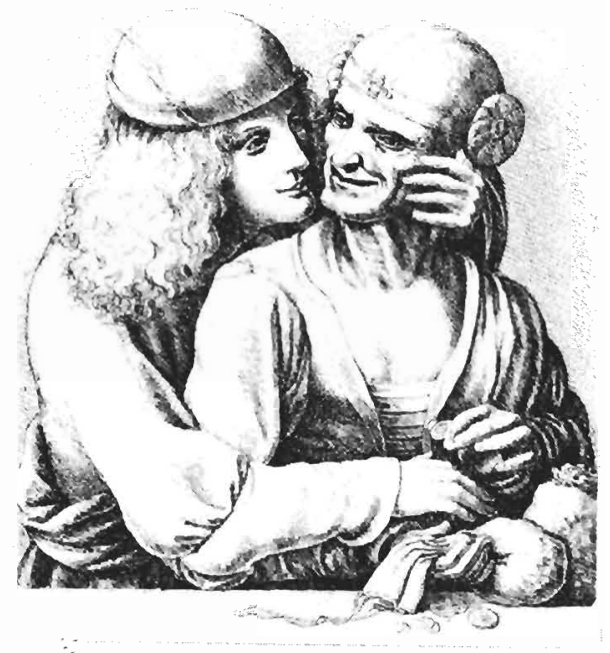


Leonardo da Vinci is believed to have executed a drawing of an Old Woman and Young Man in Milan in the late 1490s, which is known today through two copies. Jacob Hoefnagel's drawing of 1602 (no. 5), so dated on the verso, and Wenzel Hollar's etching of 1646 (no. 6) are certainly Leonardesque in style, and undoubtedly reflect first-hand experience with a drawing by Leonardo or someone from his studio. Inscribed "Leonardo" (top right), the Hoefnagel draws on a Leonardo that Hoefnagel probably saw in the Kunstkammer of Rudolph II, his employer beginning in 1602. Rudolph purchased all the Leonardo paintings, drawings, and writings owned by the Italian painter and art theorist Gian Paolo Lomazzo at his death in $1600 .{ }^{273}$

Hollar's etching is inscribed: "Leonardo da Vince inu. W. Hollar fecit. Ex Collectione Arundeliana 1646." Thomas Howard, duke of Arundel, was a passionate collector of Leonardo's drawings and writings. He employed Hollar before 1630, early in the artist's career, until the duke's death in 1646. Hollar resided from 1636 to 1641 in Arundel's London home, where he copied from the largest extand collection of Leonardo's drawings (now in Windsor Castle). Later, in 1644, Hollar worked in Antwerp where plates engraved with Leonardo caricatures and cartoons were said to have been stacked in his studio. ${ }^{274}$ In 1646 Hollar etched his Unequal Couple, apparently after his own record of a Leonardo drawing that he had seen in Arundel's collection.

Leonardo's well-known love of contrasts probably drew him to the Northern theme of Unequal Love. In his Treatise on Painting, which dates after 1490, Leonardo writes:

I say also that in narrative paintings one ought to mingle direct contraries so that they may afford a great contrast to one another, and all the more when they are in close proximity; that is, the ugly next to the beautiful, the big to the small, the old to the young, the strong to the weak; in this way you will vary as much and as close together as possible. ${ }^{275}$

The opportunity to contrast man and woman, youth and age, beauty and ugliness, as well as poor and rich probably pointed Leonardo in the direction of the Housebook Master's drypoint (no. 2) as reflected by Meckenem's copy (no.4), which dates only ten years before the Leonardo and is the only earlier yet similarly composed work on the them. Silver observes, quite rightly, that the Leonardo draws on the Meckenem, which transmitted the Housebook Master's original design in reverse.

Leonardo clearly satirizes the relationship of the old, wrinkled, gap-toothed woman and her beautiful, avaricious young partner. Greater intimacy is established through the closer embrace and by the placement of the young man's hand on the old woman's cheek. However, Leonardo maintains the original figure types, especially the young man with long hair.

\section{Old Man and Young Woman}

Jacopo de’ Barbari (ca. 1450-ca. 1517, Venetian, active in Gemrany and the Netherlands from 1500)

1503; panel; 404 x 324 mm. Philadelphia Museum, John G. Johnson Collection. Johnson Collection catalogue 1966, p. 40, no. 167. Servolini 1944, pl. XXVI. De Hevesy 1925, pl. XXX. See text fig. 66.

Koepplin and Falk credit Jacopo with the possible invention of what may be another Unequal Couple, a representation of an old male lover mocked by a fool. It is considered to be a painting on cloth in watercolor and is included in a description, printed in 1507 , of works in the Wittenberg castle. ${ }^{276}$

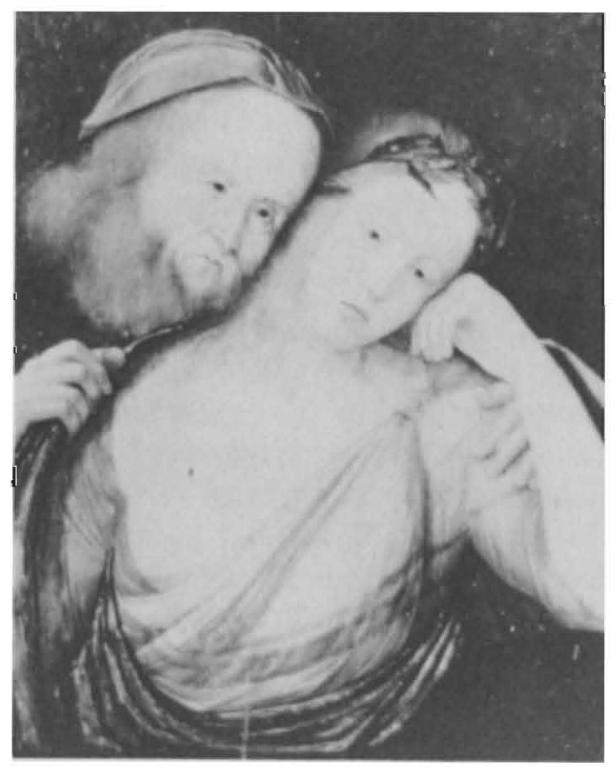


8 Old Man and Young Woman (contemporary replica or copy of no. 7, now lost)

After Jacopo de' Barbari

Copper; 451 x 359 mm. Berlin, Lepke's Sale, 22 March 1920. Johnson Collection catalogue 1966, p. 40, no. 167.

De Hevesy 1925, p. 47.

\section{Old Man and Young Woman}

Hans Baldung, called Grien (1484/85-1545, Strasbourg) 1507; engraving; 173 x 139 mm. H.2.72; N.3.330.944; P.3.319.3. Oettinger and Knappe 1963, fig. 94. Lauts 1959 , p. 213, fig. 4. Hugelshofer 1933, p. 170. Parker 1925, p. 421. See discussion following no. 14. See text fig. 58.

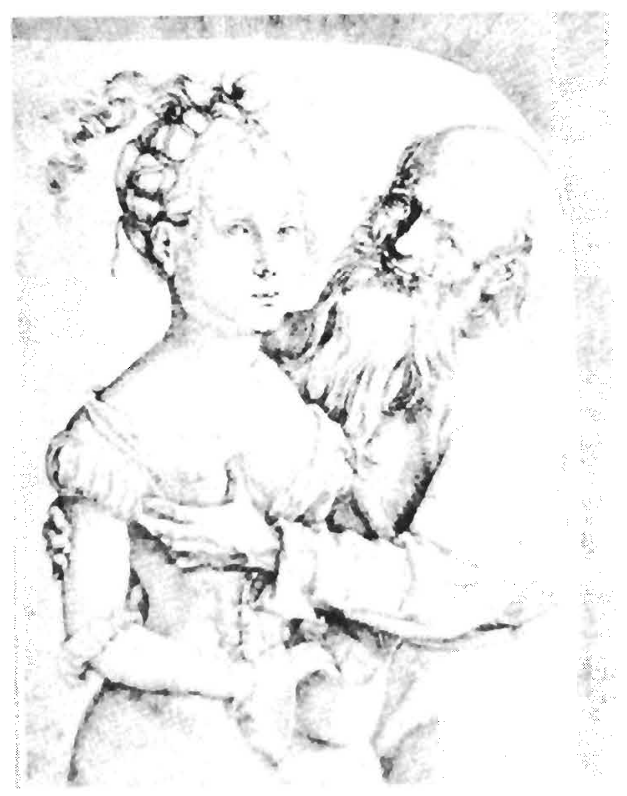

10 Old Man and Young Woman (copy of no. 9)

Hans von Kulmbach (ca. 1480-1522, Nuremberg)

Ca. 1510; panel. Private Collection. Wescher 1938, pp. $377 f$, dates the painting around 1510. See text fig. 77 .

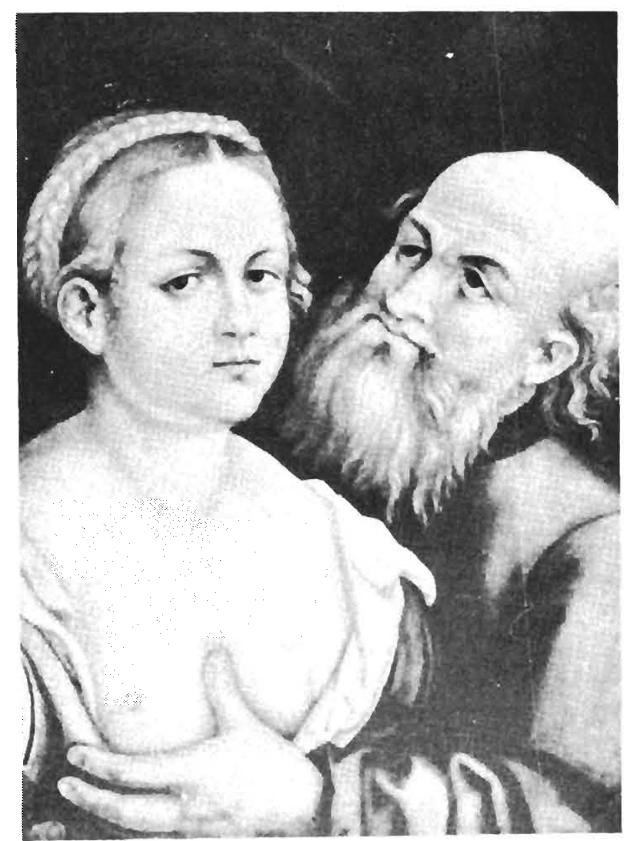


Niklaus Manuel (1480-1530, Basel)

Ca. 1517 or after; chiaroscuro drawing in pencil and pen on red paper heightened in white; 131 x 197 mm. Basel, Kupferstichkabinett, Kunstmuseum. Von Mandach and Koegler [1942], p. LIV, pl. 76; p. 27 for the date. See text fig. 59.

12 Old Man with Young Woman and Young Man with Old Woman

German

Ca. 1510-20; woodcut; 265 x $365 \mathrm{~mm}$. Schreiber 4.115 . 1977. Coupe 1967, p. 666. Diedrichs 1908, vol. 1, fig. 219. See text fig. 35 .
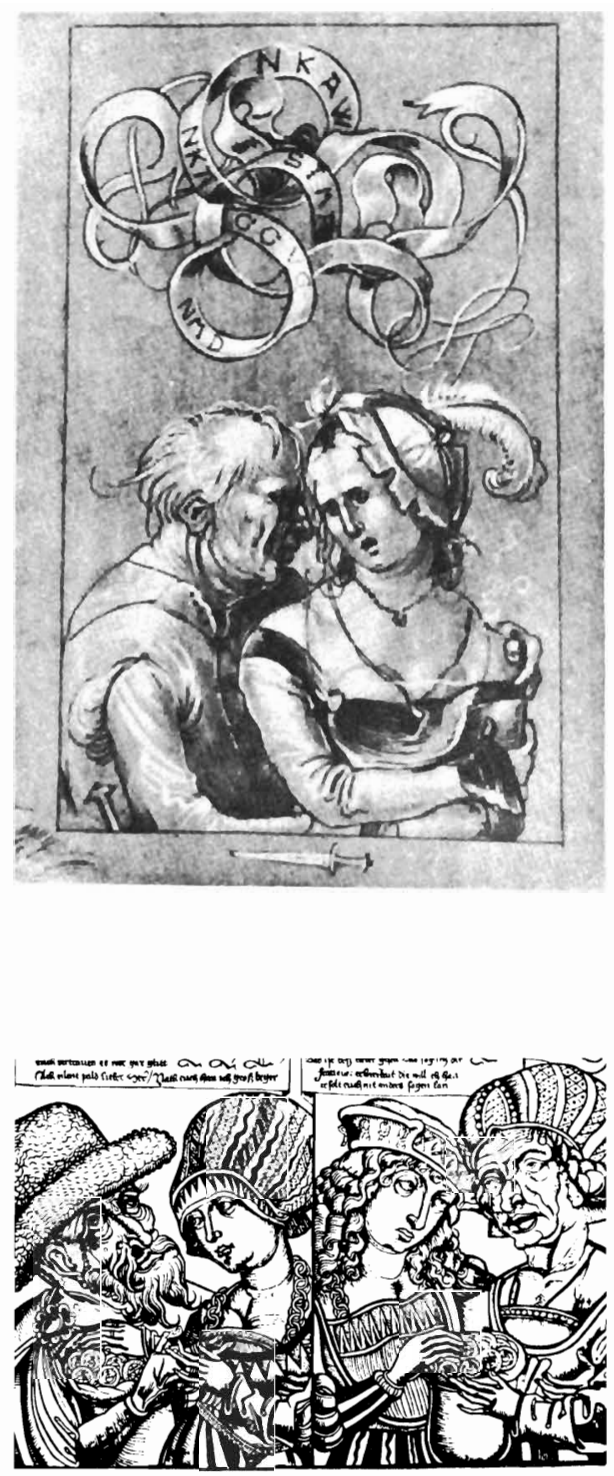

Schreiber dates the woodcut about 1500 . The "slitted" costume suggests a date closer to 1510 or 1520, when it was depicted in German art. Neck chains were probably popular even before the turn of the fifteenth century; the Strasbourg preacher Geiler von Kaisersberg referred to them satirically in 1498 as "umbhencken den halss mit viel guldenden ketten." 277 Larger and more ostentatious collections of chains were not represented until around 1520. The medium-weight neck chains and the elaborate costume worn by the young woman here suggest a date of about 1510 to 1520 for the work. The inclusion of two sets of Unequal Couples within this composition also suggests a similar date, for it was not until about 1512 that this occurs in other examples (see no. 64). The stringy fingers, the oval-shaped woman's face, and the sumptuous curls of the youth are characteristic of the art of the end of the fifteenth century. This woodcut may therefore reflect an earlier work transmitted by a later artist, who updated the costume. Similarities in facial type and composition to the Housebook Master and Meckenem prints (nos. 1-4) suggest the possibility that all these works go back to a lost engraving by Master E. S., who was active around 1450 to 1466/67 in southwest Germany near Lake Constance. Leo Baer once thought E. S. apprenticed the Housebook Master who copied and adapted a number of E. S.'s works. See, for example, the Housebook Master's St. Barbara and Mary Magdalen with Five Angels as well as a work from the Housebook, which was inspired by the suit of acrobats from E. S.'s playing cards. ${ }^{278}$ 
Lucas van Leyden (ca. 1489-1533, Leyden)

1520; etching with engraving; $104 \times 73 \mathrm{~mm}$. B.150;

H.10.170. Lavalleye [1967], fig. 127. See text fig. 39.

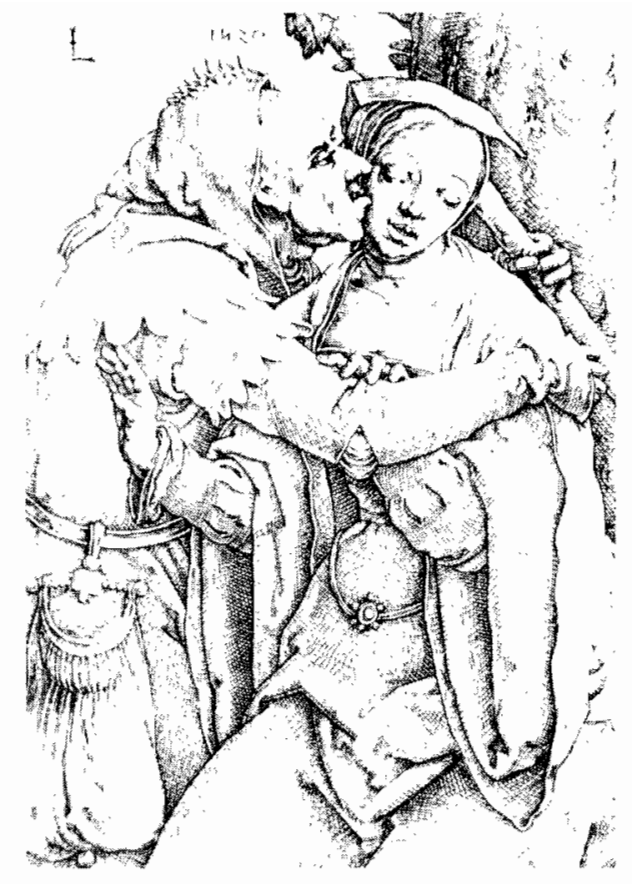

\section{Old Woman and Young Man}

Lucas Cranach the Elder (1472-1533, active Saxon court, Wittenberg, from 1505).

Ca. 1520-22; panel; 370 x 305 mm. Budapest, Szepmuveszeti Muzeum. Pigler 1968, vol. 1, p. 163, 110. 137; vol. 2, pl. 349. Friedländer and Rosenberg 1932, p. 55, no. 131, dated; fig. 131. See text fig. 54.

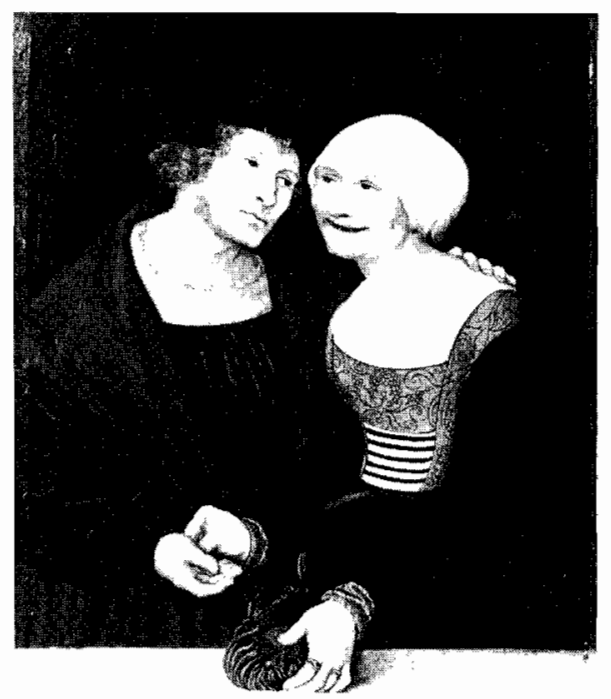

This painting is considered the earliest of forty-four representations of Unequal Lovers by Lucas Cranach the Flder, his sons including Lucas Cranach the Younger, and his school. Only three of these (nos. 14-16) represent the more unusual combination of an old woman and a young man. Max J. Friedländer, Jakob Rosenberg and Eberhard Ruhmer have suggested that Cranach's Unequal Couples go back to Massys, to N Netherlandish models that Cranach may have seen during his Netherlandish trip of 1509, or even to such Italian models as Jacopo de' Barbari's 1503 painting in Philadelphia. ${ }^{279}$ None of these is very convincing. The painting has been dated ca. 1520-22, and Cranach's Old Man and Young Woman (no. 17) is dated 1522 on the painting. The Massys (no. 18) has recently been dated somewhat later, to about 1522-23. The later dating, as well as the different formats and approaches to the theme adopted by Massys and Cranach, suggests that the artists were inspired less by each other than by other literary or artistic sources (see pp. 68-71) like the Leonardo (see nos. 5 and 6); it also nakes doubtful Cranach's dependence on Massys. The Netherlandish works that would have been available to Cranach during his trip there are the drypoints of the Housebook Master (nos. 1 and 2), whose Netherlandish origins are still debated, and the Meckenem engravings (nos. 3 
and 4) copied after the Houscbook Master. Meckenem's full-length Unequal Couple of about 1497 (no. 60 ), in addition, would have circulated more widely than the drypoints, given the greater number of engravings that can be pulled from one plate. Jacopo's painting (no. 7), the only original Italian work on the theme extant today, may have been painted at Wittenberg for the Saxon elector Frederick the Wise. In 1505 Cranach succeeded Jacopo as court painter for Frederick, most likely painting then many of his Unequal Couples. Thus Jacopo's painting may have influenced Cranach, or, more possibly, the patromage of Frederick the Wise or his circle may have accounted for the appearance and popularity of the Unequal Lovers theme there.

In form, especially their three-quarter length, Cranach's representations, as exemplified by no. 14, are closer to Baldung's 1507 engraving (no.9) than to Jacopo's painting. The grinning old woman and old man -in type and in the close proximity of their heads show the influence of Leonardo's reworking of the Housebook Master. Given the predominantly German tradition of the theme in art and literature before 1520, the importance placed on Netherlandish sources should be minimized.

Old Woman and Young Man (variant of no. 14)

\section{School of Lucas Cranach the Elder}

Print; $198 \times 144 \mathrm{~mm}$. Inscribed left bottom: "Alt. I4 Lat. not illustrated 1IUnc," betow: "Cranach pinx." Schuchardt 1851, pt. 2, p. 333 , no. 36 .

Old Wornan and Young Man (variant of no. 14) Lucas Cranach the Elder (?)

Madrid, Marques de Ariany Collection. Witt.

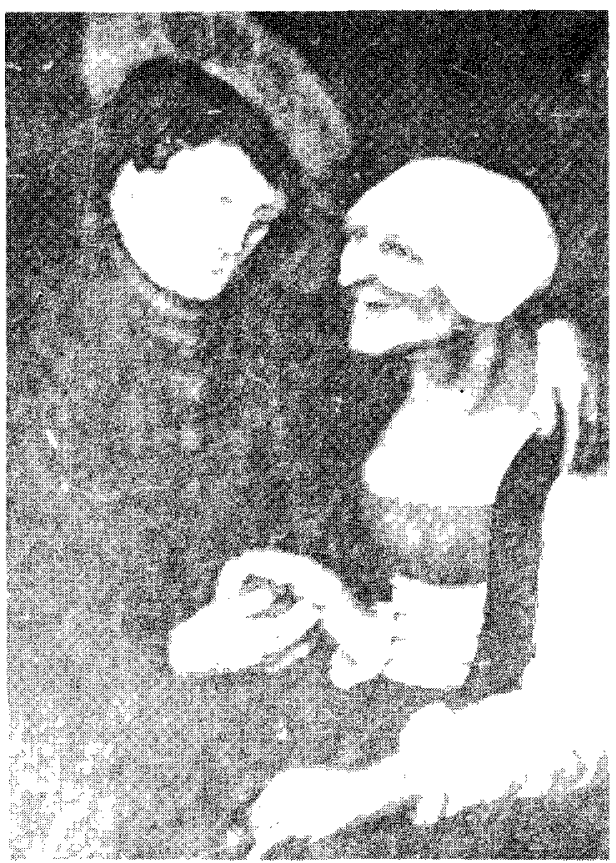


Lucas Cranach the Elder

1522; panel; $850 \times 630 \mathrm{~mm}$. Budapest, Szepmuveszeti

Muzeum. Friedländer and Rosenberg 1932, p. 55, no. 132, and fig. 132. Flechsig 1900, pl. 77. Woermann 1899, no. 16. Z. I. See text fig. 5.5 .

Old Man, Young Woman and Fool

Quinten Massys (1466-1530, Antwerp)

Ca. 1522-23; panel; $420 \times 620 \mathrm{~mm}$. Washington, Nationai Gallery. Formerly, Paris, Countess Portales Collection. De Bosque 1975, p. 193, Silver 1974, pp. 104-23, especially pp. 106, 107, for the date. Friedländer 1924-74, vol. 7, fig. 54. See p. 71 for the relation to Lucas van Leyden's Prodigal Son (?) woodcut, and commentary under no. 14, for the relation to Cranach's paintings. See text fig. 40.

Old Man, Young Woman and Fool, with Still Life Below (variant of no. 18)

Netherlandish

After 1575; $762 \times 640 \mathrm{~mm}$. Liège, Bibliothèque de l'Universite, Wittert Collection. Formerly Baron Adrien Wittert, Chateau de Colonster. Siecle de Bruegel 1963, p. 133, no. 168, dates the work after the death of Jan Massys in 1575 because of the stilllife; fig. 32.
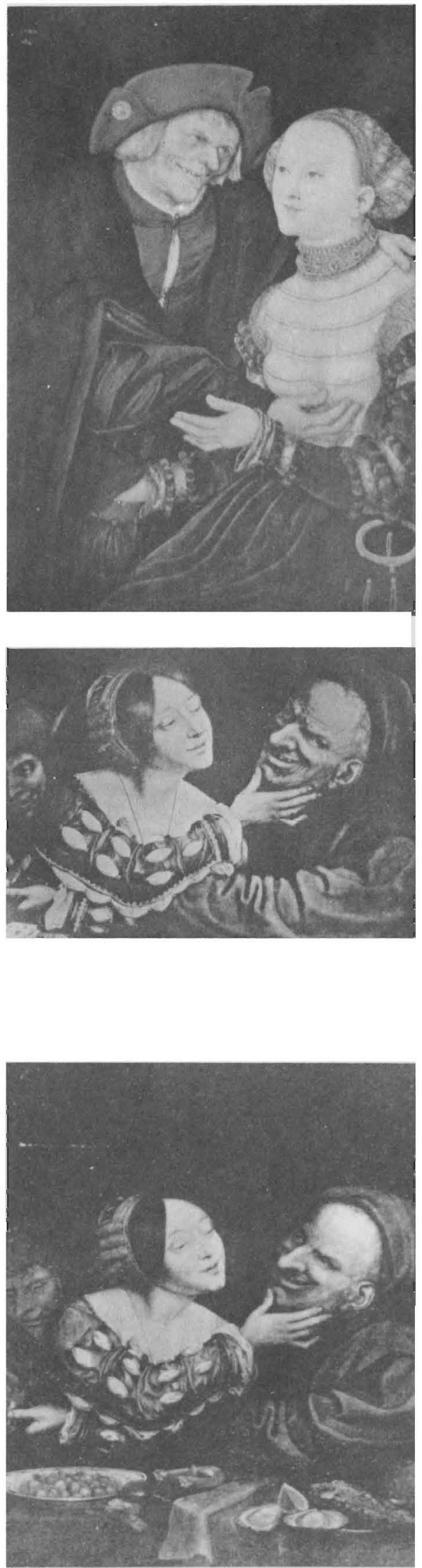
Old Man, Young Woman and Fool (variant of no. 18)

Netherlandish, in the Manner of Jan Massys

Ca. 1525-50; 720 x 150 mm. Douai, Musée. Inscribed: “Gij eij siet so ouwer so sotter" ("The older one is, the more foolish one grows"). DIAL no. 42D3121. RKD. Warburg.

Old Man and Young Woman

School of Lucas Cranach the Elder

1522; panel; 860 x $630 \mathrm{~mm}$. Budapest, Szepmüveszeti Muzeum. Pigler 1968, vol. 1, p. 167, no. 134. Witt. Z. I.

22 Old Man and Young Woman (variant of no. 39)

Lucas Cranach the Elder

Ca. 1525; panel. Erfurt, Städtisches Museum. Z.I. 
Lucas Cranach the Elder

Ca. 1525-30; panel; 315 x 230. Darmstadt, Hessisches Landesmuseum. Koepplin and Falk 1974-76, vol. 2, p. 567, no. 462; p. 569, fig. 294a. Von der Osten 1973, p. 203. Z. I.

Cranach depicted peasants in only two of his Unequal Couples, one of which is known today through a nineteenth-century lithograph (see no. 24). The couples in these two works are unequal more in station than in age, at least in relation to the normally very old age of the man.

Middle-Aged Peasant and Young Woman

School of Cranach

Lithograph by Jean-Baptiste Mauzaisse (1784-1844) after Cranach. Koepplin and Falk 1974-76, vol. 2, p. 567, and p. 568 , fig. 294 . Schuchardt $1851-71$, pt. 2, p. 333, no. $3 \%$ Witt.

\section{Old Man and Young Woman}

Hans Baldung

1527; panel; 285 x 230 mm. Liverpool, Walker Art Gallery. Walker Art Gallery catalogue text vol., p. 12, no. 1221; plate vol., no. 1221. Bromwelle 1955, p. 352, fig. 34. See text fig. 56 .
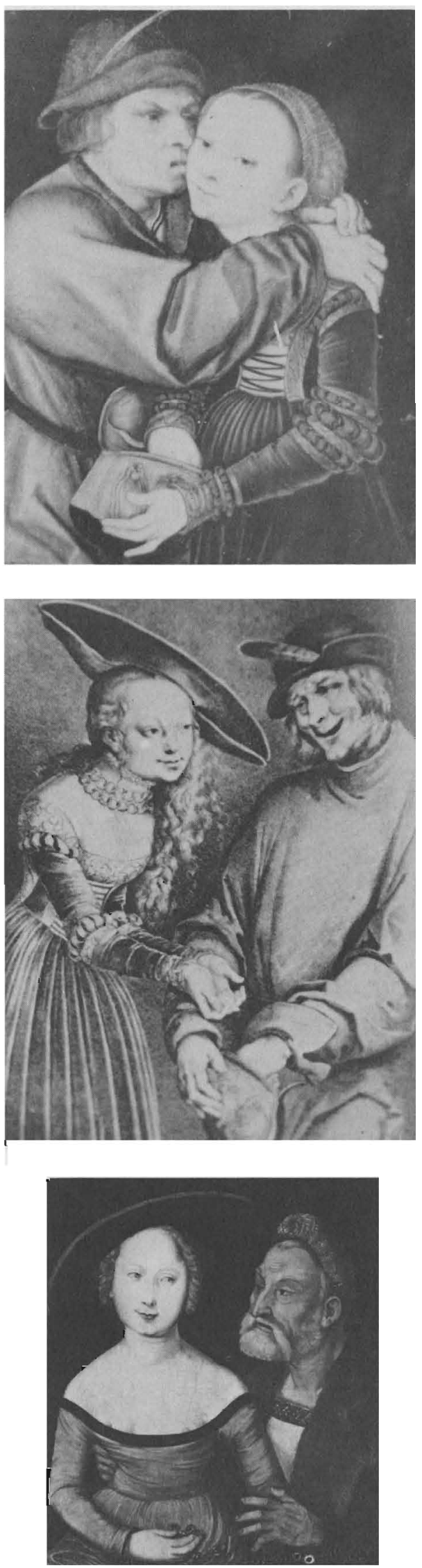
Hans Baldung

1528; panel; 295 x 240 mm. Karlsruhe, Staatliche Kunsthalle. Altdeutsche Meister 1964, no. 42, and fig. 42. Wescher 1938, pp. 376ff., ill. p. 379. Buchner and Feuchtmayr 1924, vol. 1, p. 297. See text fig. 57.

Old Man and Young Woman

Wolfgang Drodel (born ca. 1500, active until 1561 in Saxony, school and workshop of Lucas Cranach the Elder) 1528; oil on board; 509 x 359 mm. New York, Ira Spanierman Gallery. ${ }^{280}$ See text fig. 64.

Old Man and Young Woman

Lucas Cranach the Elder

1528; panel. Munich, Bayerische Staatsgemäldesammlungen. Z. I.
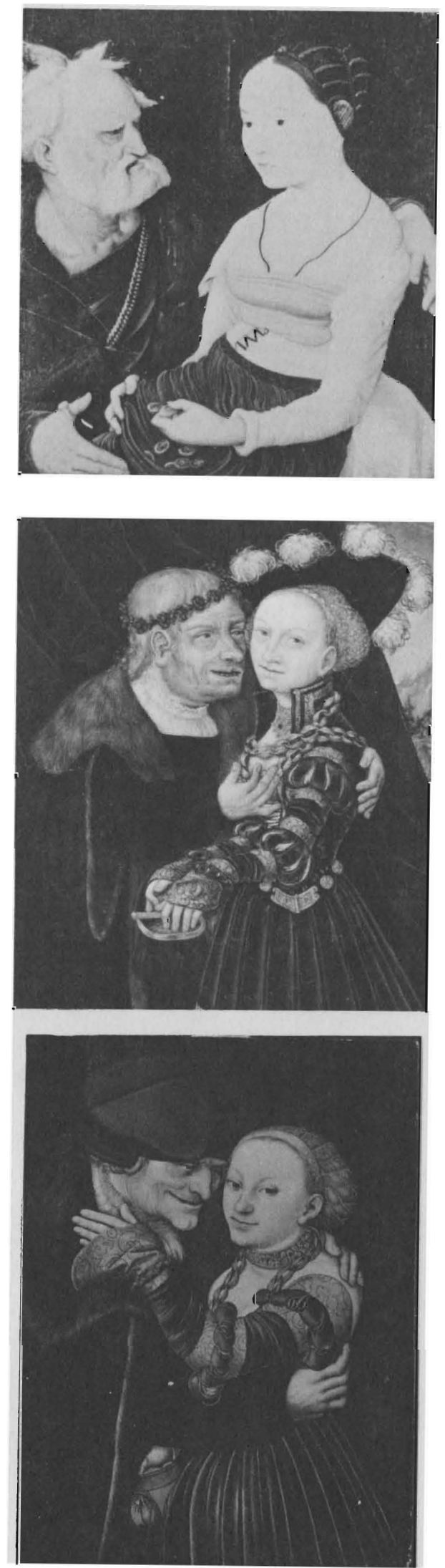
Old Man and Young Woman

Lucas Cranach the Elder

Ca. 1530; panel; 600 x 525 mm(?). Munich, Bayerische Staatsgemäldesammlungen. Formerly Schleissheim. Friedländer and Rosenberg 1932, p. 72, no. 235f or 235g. Schuchardt 1851-71, pt. 2, p. 112, no. 391, gives the dimensions. Witt. Z. I.

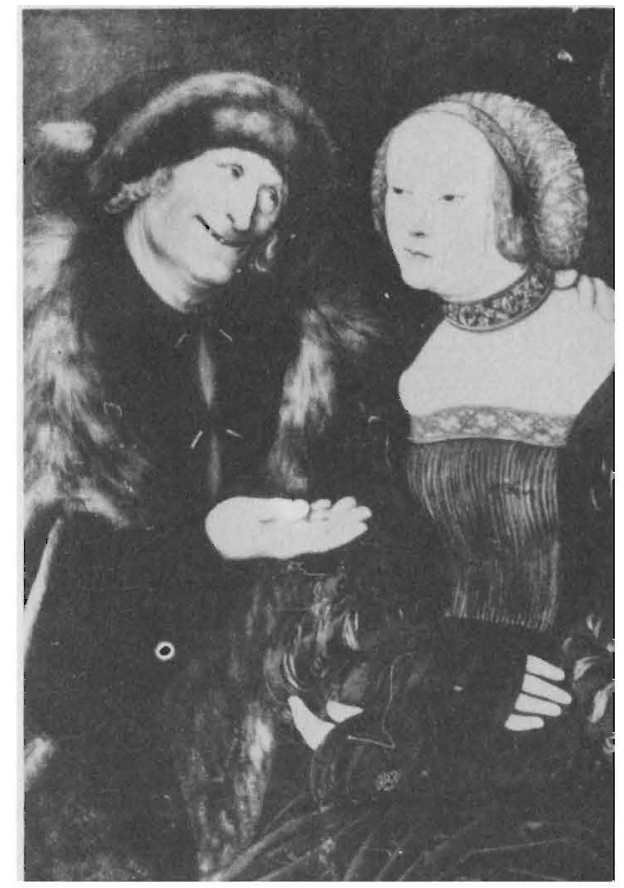

30 Old Man and Young Woman (copy of no. 29)

Lucas Cranach the Elder or School

Budapest, Collection Baron Herzog. Biermann 1912, p. 418, fig. 3 .

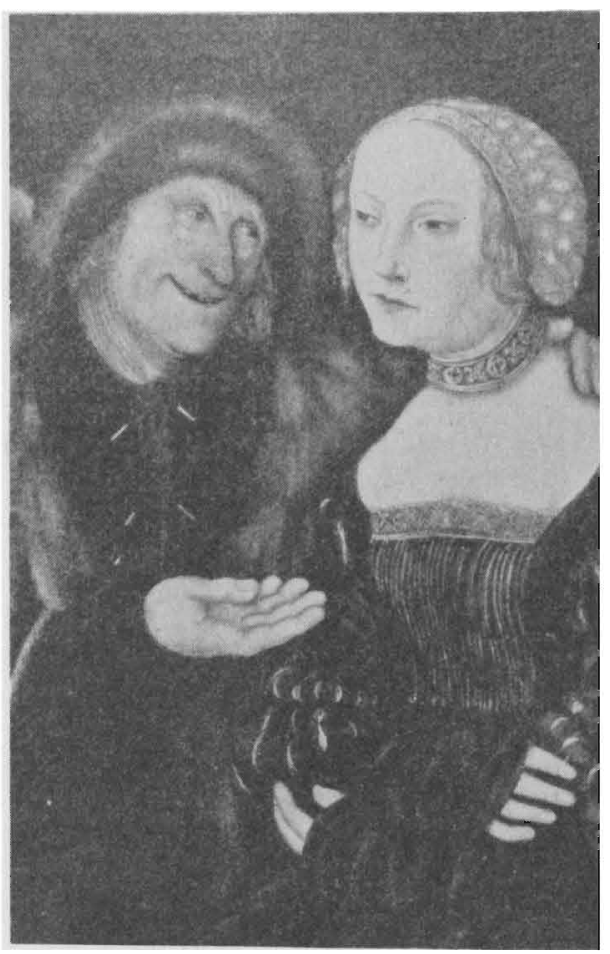




\section{Old Man and Young Woman}

Lucas Cranach the Elder

Ca. 1530; panel; 387 x 258 mm. Düsseldorf, Kunstmuseum. Koepplin and Falk 1974-76, vol. 2, p. 567, no. 463, and p. 568, fig. 293. Friedländer and Rosenberg 1932, p. 72, no. 235a. Witt. Z.I. Cf. nos. 32 and 33 for related versions.

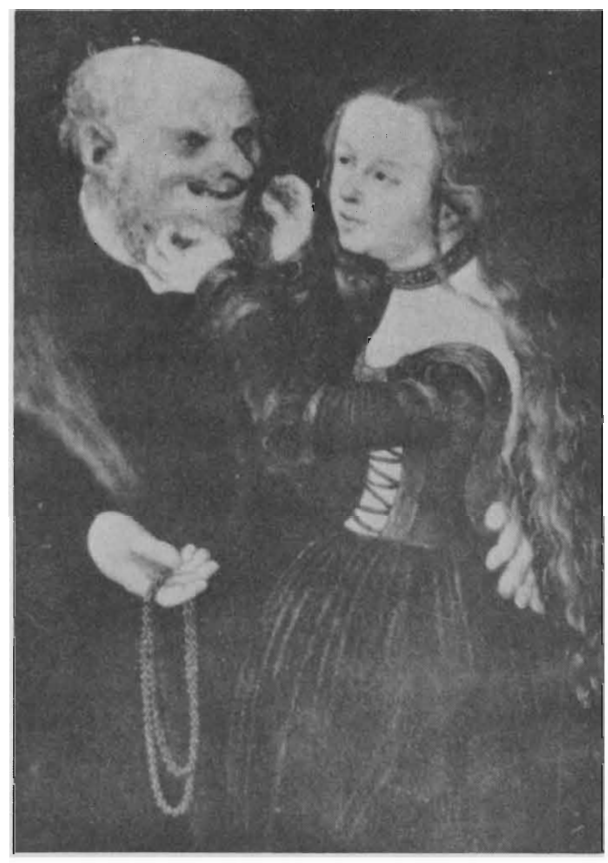

32 Old Man and Young Woman (replica of no. 31)

Lucas Cranach the Elder

not illustrated

Sibiu, Rumania. Schade 1974, p. 387, n. 540.

33 Old Man and Young Woman (weak copy of no. 31)

School of Lucas Cranach the Elder

not illustrated

Munich, Helbing Auction 19 February 1913, no. 15.

Friedländer and Rosenberg 1932, p. 72, no. 235a.

\section{Old Man and Young Woman}

Lucas Cranach the Elder

Ca. 1530; panel; 880 x 600 mm. Nuremberg, Germanisches Nationalmuseum. Lutze and Wiegand 1937, text vol., p. 40, no. 218; plate vol., fig. 370. Friedländer and Rosenberg 1932, p. 72, no. 235; fig. 235. Katalog der Gemaldesammlung 1909, p. 70, no. 218. Schuchardt 1851-71, pt. 2, no. 377 ; pt. 3 , p. 175 . Cf. nos. 35 and 36 for a near copy and variant. See text fig. 53 .

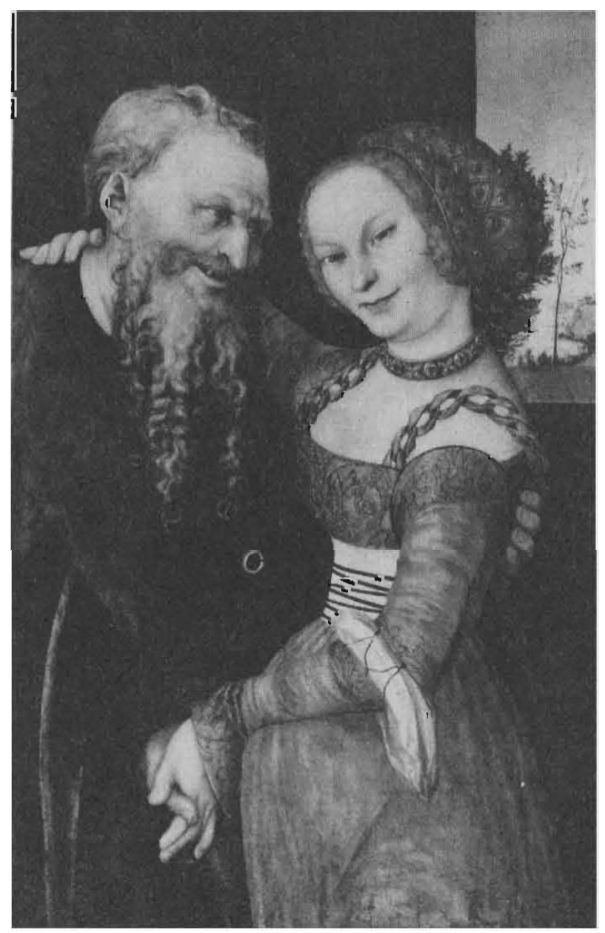


Old Man and Young Woman (copy of no. 34)

Lucas Cranach the Younger

Ca. 1530; panel; $590 \times 455 \mathrm{~mm}$. Lucerne, Fischer Sale ca. 1970. Formerly(?) Collection Coray-Stoop, Haldengut, Erlenbach-Zurich. Friedländer and Rosenberg 1932, p. 72, under no. 235.

Old Man and Young Woman (variant of no. 34)

Lucas Cranach the Elder

Ca. 1530-40. Besançon. Witt.

\section{Old Man and Young Woman}

Lucas Cranach the Elder

1531; panel; 495 x 345 mm. Prague, Rudolphinum.

Friedländer and Rosenberg 1932, p. 72, no. 235c. Katalog

der Gemalde-Galerie 1912, p. 53, no. 119. Schuchardt 1851-71, pt. 2, p. 109 , no. 387.

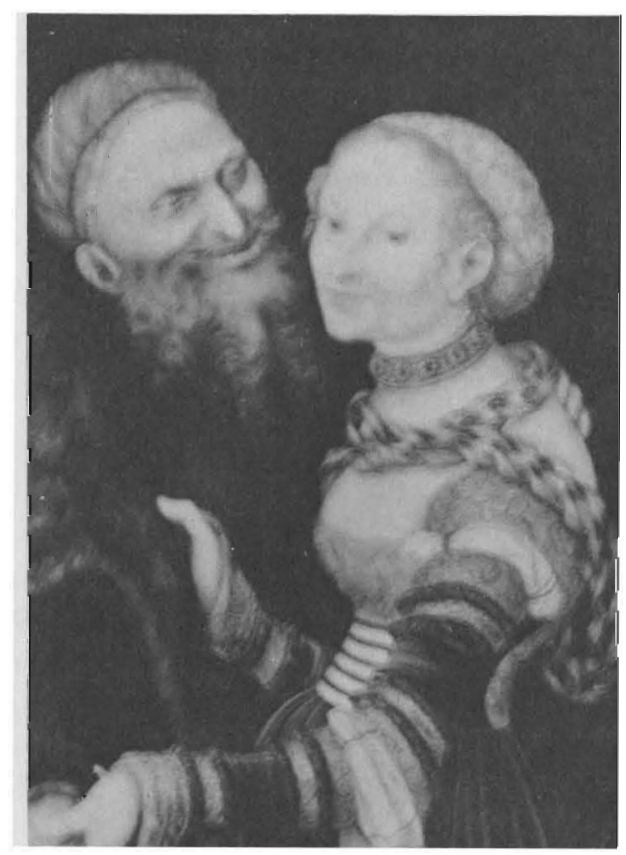

not illustrated 
Lucas Cranach the Elder

Ca. 1530; panel; 380 x 250 mm. Prague, Rudolphinum. Schade 1974, pl. 180. Friedländer and Rosenberg 1932, p. 72 , no. 233, and fig. 233. Katalog der Gemalde-Galerie 1912, pl. 180.

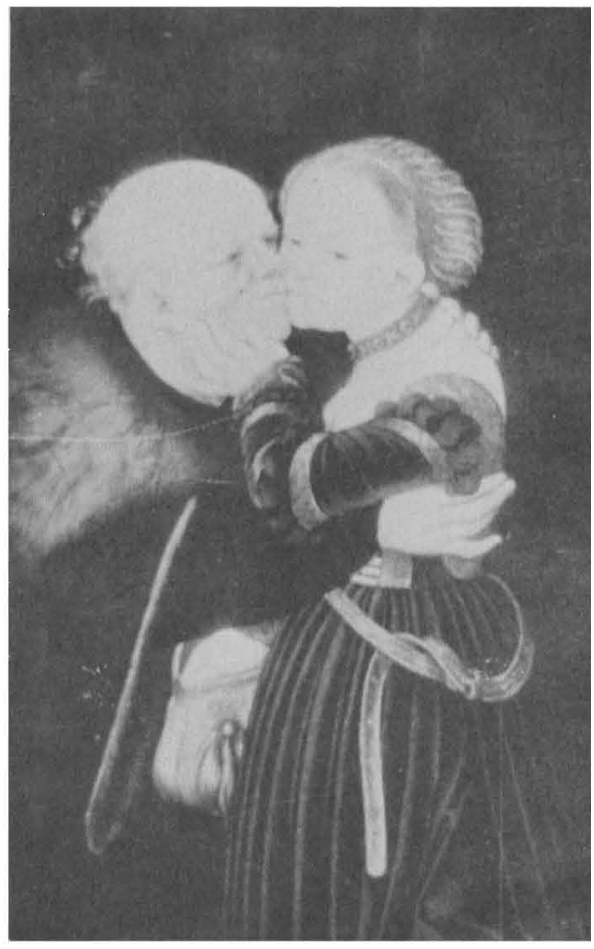

Old Man and Young Woman

Lucas Cranach the Elder

$390 \times 255 \mathrm{~mm}$. Paris(?). Z. I. See also nos. $40-43$ for weaker versions of this best of five.

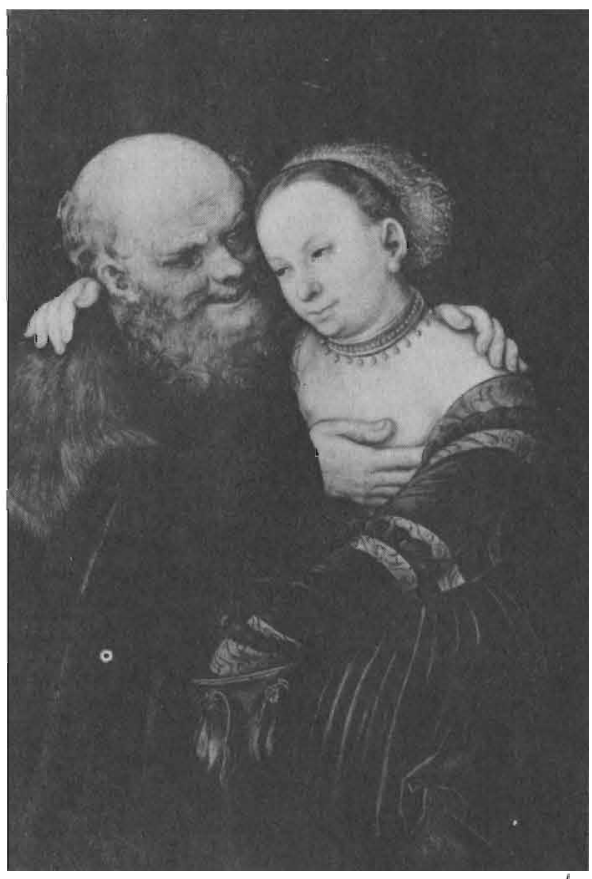


Old Man and Young Woman (copy of no. 39) Lucas Cranach the Elder(?)

1541. Munich, J. Scheidwimmer Gallery. Z. I.

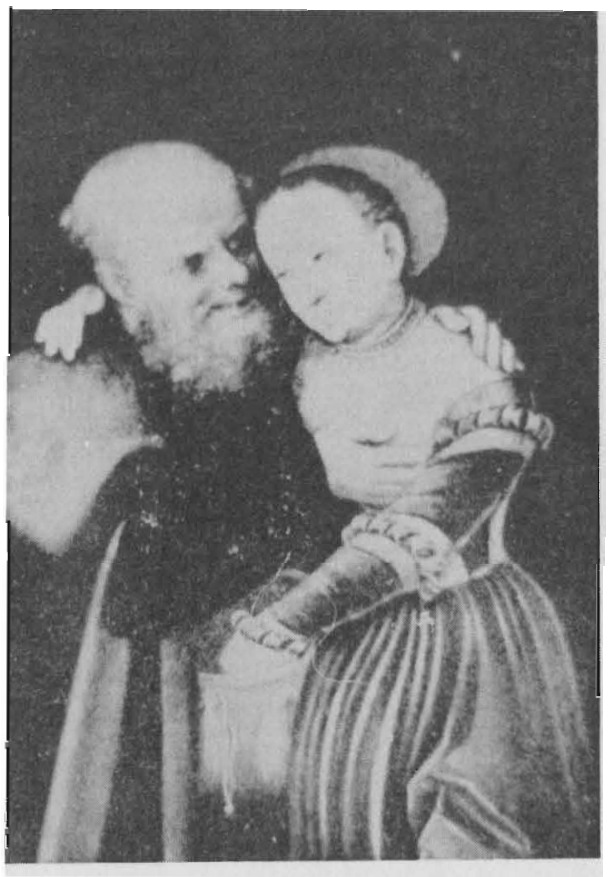

41 Old Man and Young Woman (variant of no. 39) Lucas Cranach the Younger $365 \times 270$ mm. Budapest, Sale Ernst Museum 21 February 1921 . Witt.

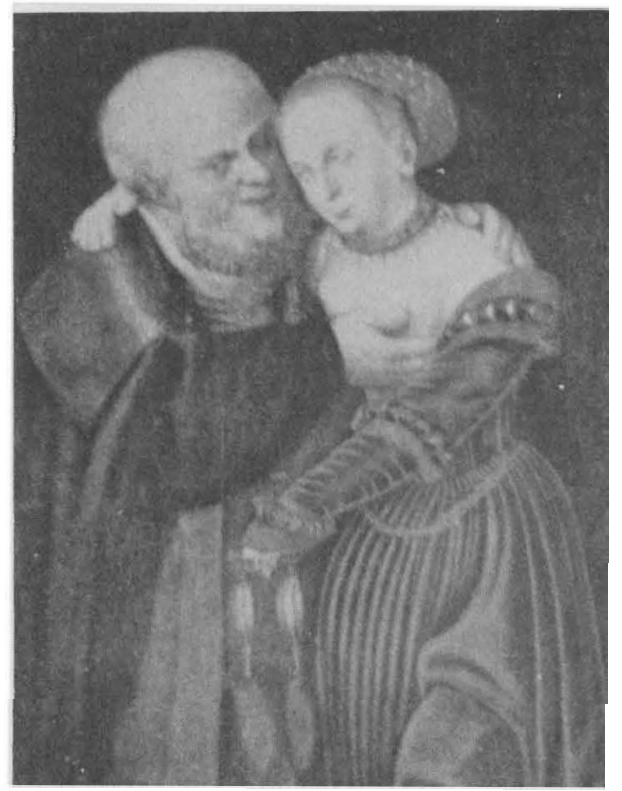


Cologne, Sale Lempertz 11 November 1964. Witt.

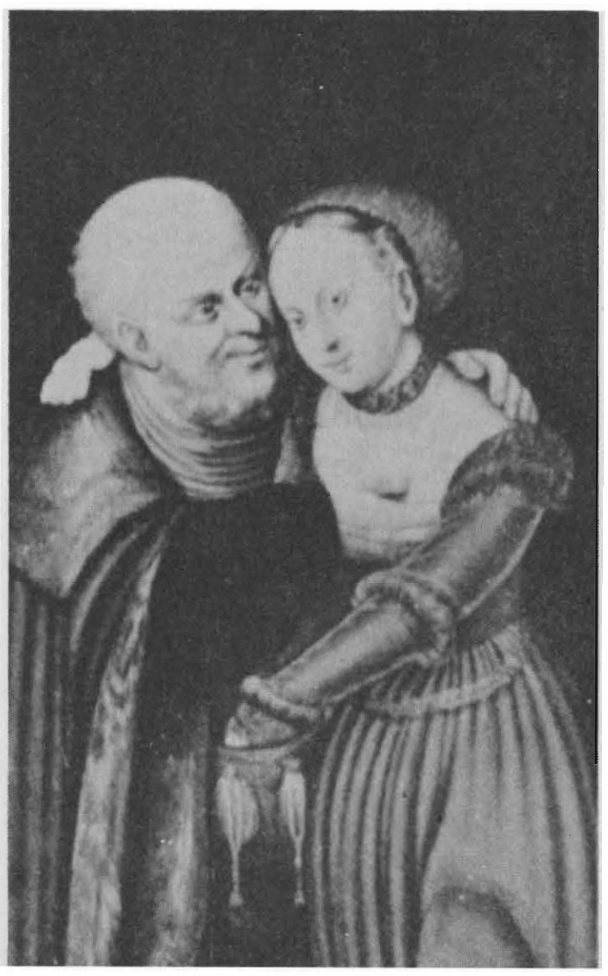

Old Man and Young Woman (variant of no. 41)

School of Lucas Cranach the Elder

Oil on panel and mother-of-pearl; $430 \times 260 \mathrm{~mm}$. Munick Weinmüller Sale of the U. Denon Collection, Paris, 1829. Formerly Royal Saxon galleries. Witt. Seal on the right suggests it was a Kunstkammer piece.

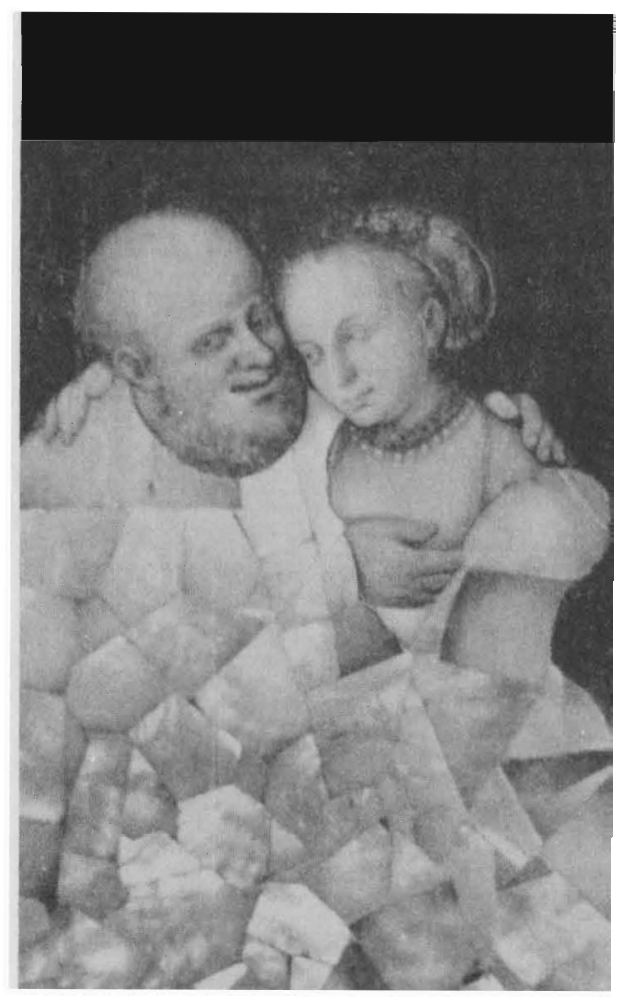


Lucas Cranach the Elder

Panel; 370 x 280 mm. Vienna, C. Castiglioni Sale, Ball and Graupe 28-29. November 1930. Friedländer and Rosenberg 1932, no. 235b (location cited as Berlin). Von Falke 1930a, p. 22, no. 35; pl. 18, fig. 35. Witt.

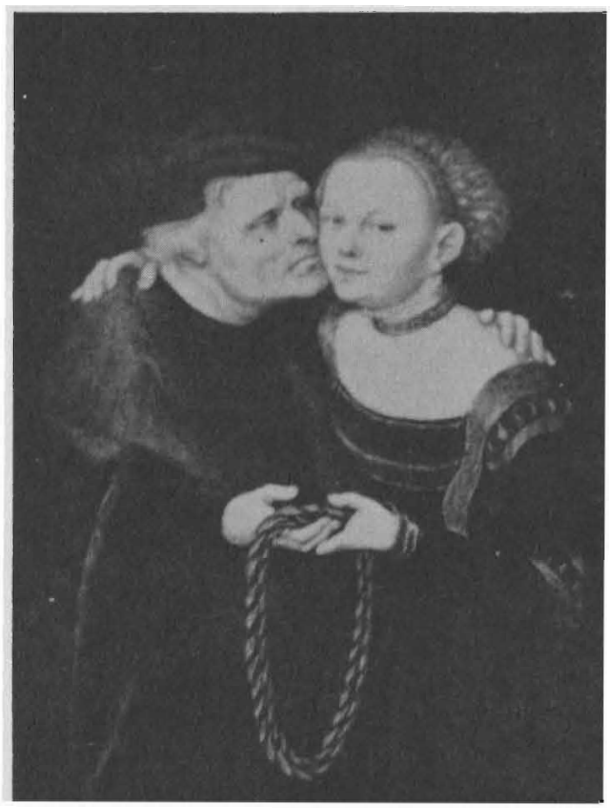

Old Man and Young Woman

Lucas Cranach the Elder

1531; panel; $510 \times 365 \mathrm{~mm}$. Vienna, Akademie der bildenden Künste. Hutter 1972, p. 29, no. 31, and fig. 26. Friedländer and Rosenberg 1932, p. 72, no. 232; fig. 232. Eigenberger 1927, p. 91, no. 559; pl. 57. Schuchardt 185171, pt. 2, no. 435 .

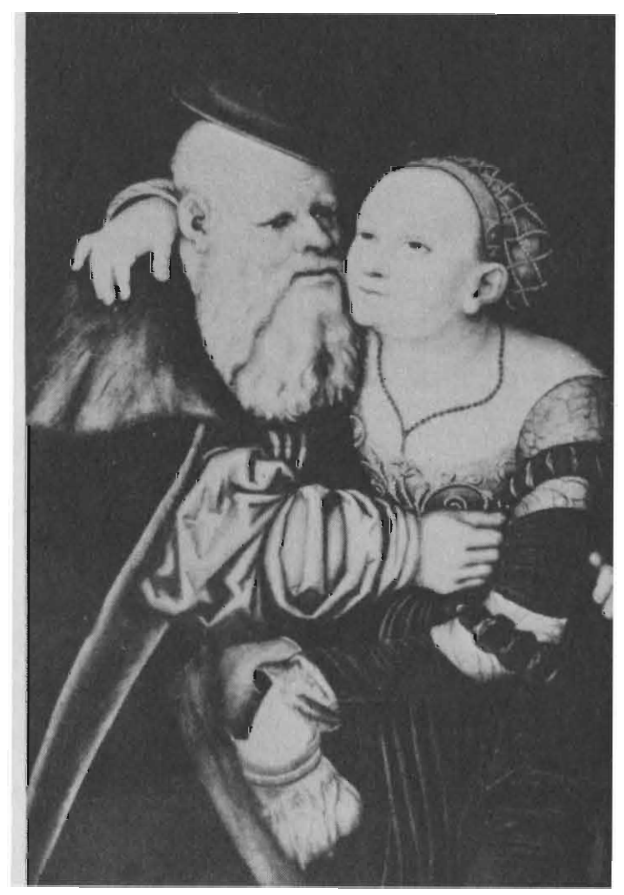


Lucas Cranach the Elder(?)

Panel; 750 x $485 \mathrm{~mm}$. Warsaw, National Museum. Chudzikowski 1969, vol. 1, p. 100, no. 267, and fig. 267.

Friedländer and Rosenberg 1932, p. 72, no. 235d. Gembarzewski 1926, p. 31, no. 270 . Witt. See nos. 47 and 48 for two weaker versions.

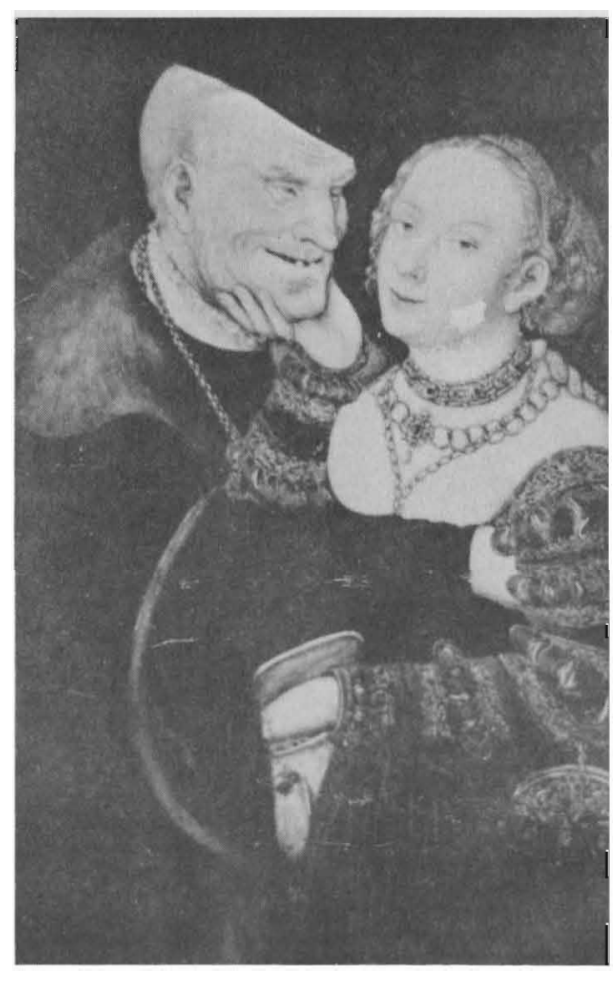

47 Old Man and Young Woman (weak variant of no. 46)

\section{School of Lucas Cranach the Elder}

1535; panel; $410 \times 320 \mathrm{~mm}$. Berlin, International Sale, 24 January 1934. Witt.

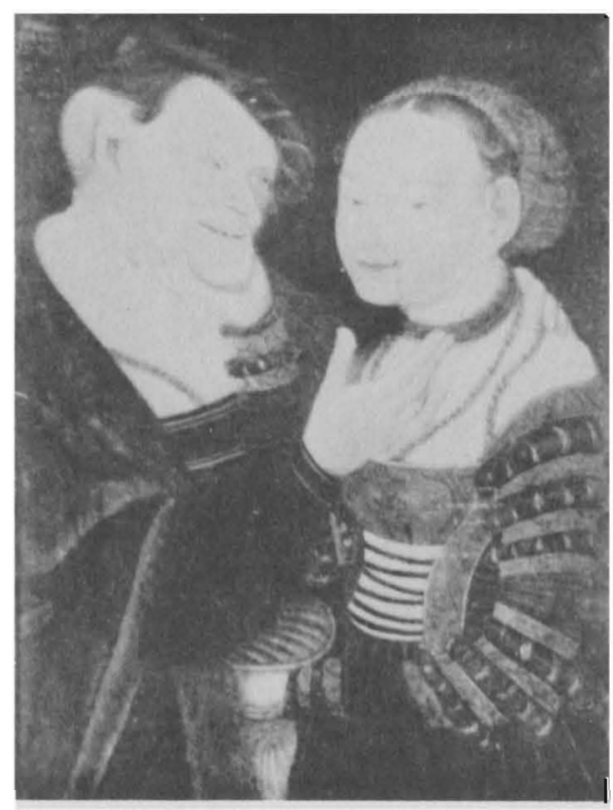


48 Old Man and Young Woman (weak variant of no. 47)

School of Lucas Cranach the Elder

Ca. 1525-30; woodcut. Munich, Weinmüller Sale 1974. Witt.

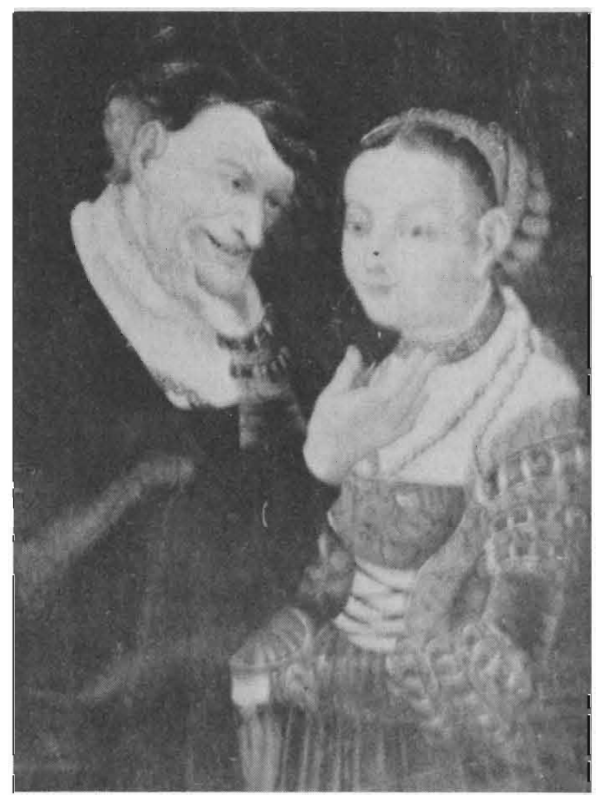

49 Old Man and Young Woman (nearly identical to no. 50) Lucas Cranach the Elder

Paris, Charpentier Gallery, 30 November 1974 Sale of the Collection of Madame K. L. Witt.

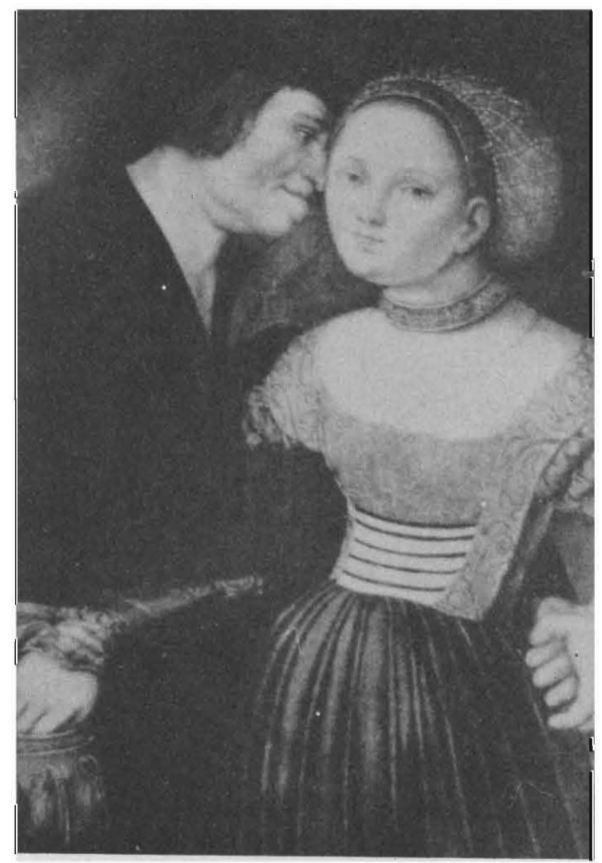


Old Man and Young Woman (nearly identical to no. 49) Lucas Cranach the Elder

Panel; 385 x 290 mm. Vienna, O. Bondy Collection.

Friedländer and Rosenberg 1932, p. 72, no. 234; fig. 234. Witt.

\section{Old Man and Young Woman}

School of Lucas Cranach the Elder

622 x 514 mm. New York, American Art AssociationAnderson Galleries, 8-9 May 1936 Sale of the E. F. Bonaventure Collection, catalogue no. 339. Witt. Z. I.
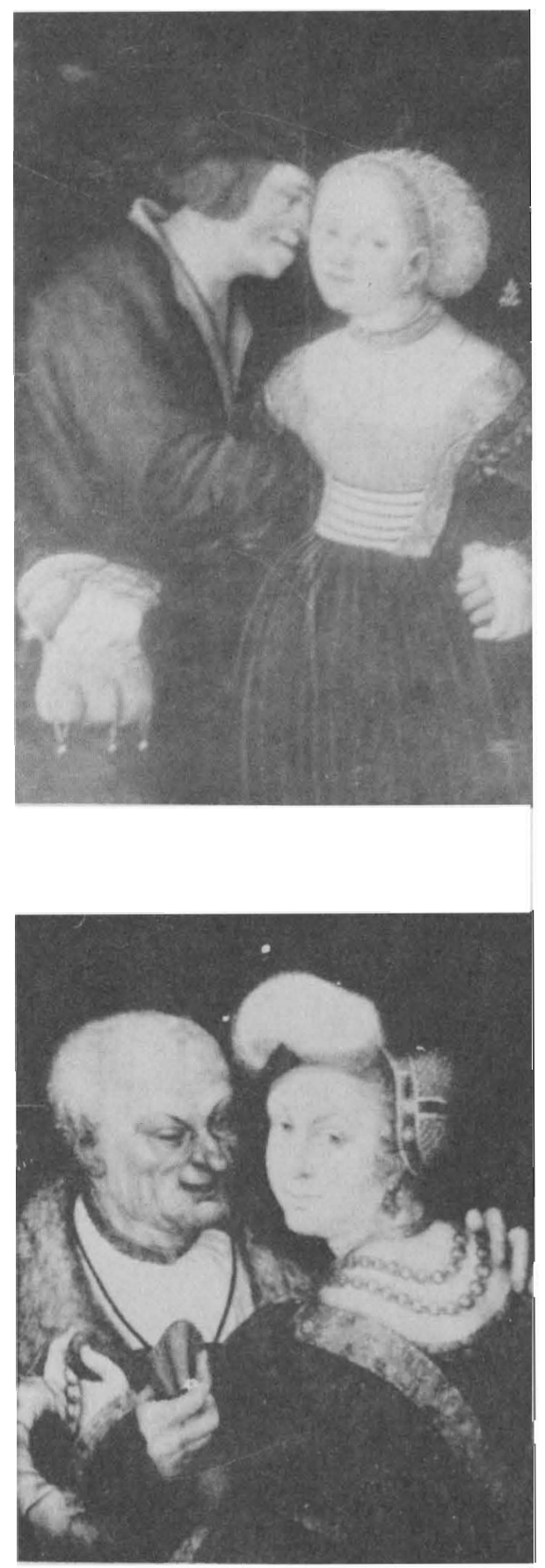
School of Lucas Cranach the Elder

Munich, Flüggen Sale, Helbing, 29-30 April 1907. Witt.

53 Old Man and Young Woman (nearly identical to no. 54 and the full-length no. 84)

Lucas Cranach the Elder

Ca. 1530-40; panel; $195 \times 145$ mm. Vienna, Kunsthistorisches Museum. Schütz 1972, pp. 25f., no. 14, dates the painting; fig. 9. Friedländer and Rosenberg 1932, p. 72, no. 235e. Possibly Schuchardt 1851-71, pt. 2, p. 137, no. 429 .

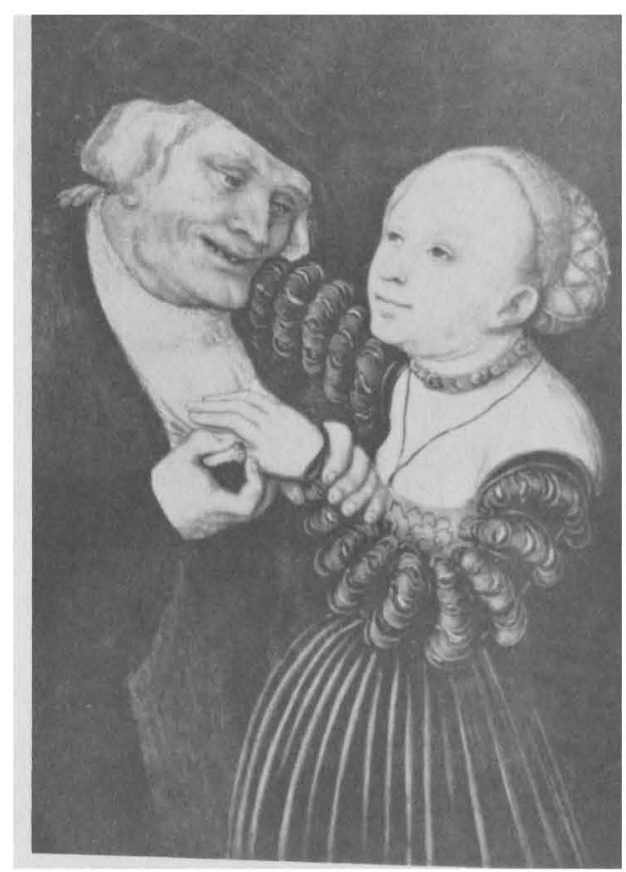


54 Old Man and Young Woman (nearly identical to no. 53) Lucas Cranach the Elder

Dowdeswell. Witt.

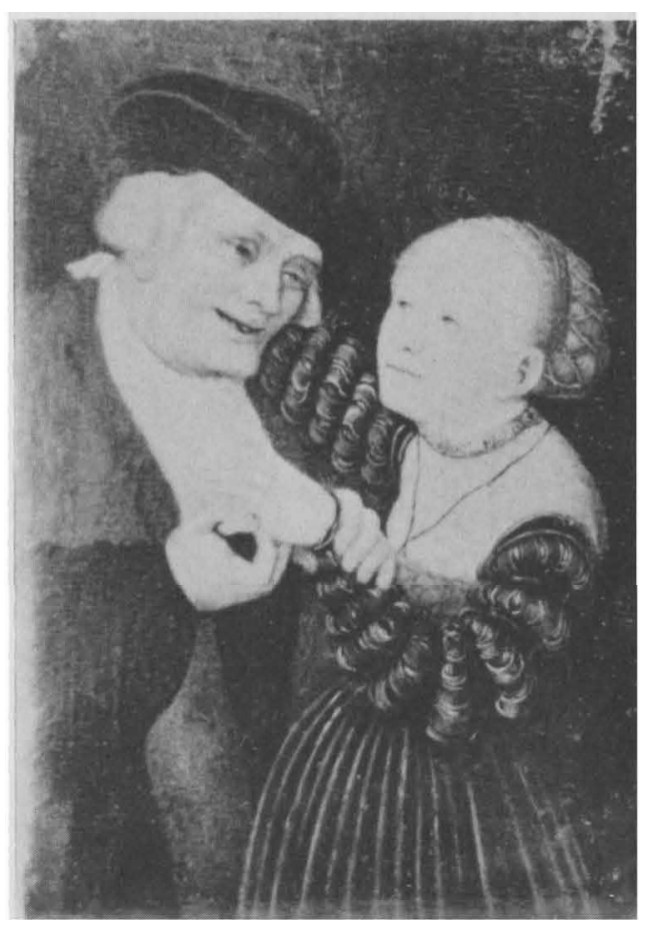

\section{EXPANDED UNEQUAL COUPLES:}

55 Old Fool and Young Woman with Dog

Master B R (active in the Lower Rhine Valley, second half of the fifteenth century, follower of Martin Schongauer)

Ca. 1490-1500; engraving; 127 x 97 mm. L.6.307.11. Lehrs 1969, fig. 437. See text fig. 30.

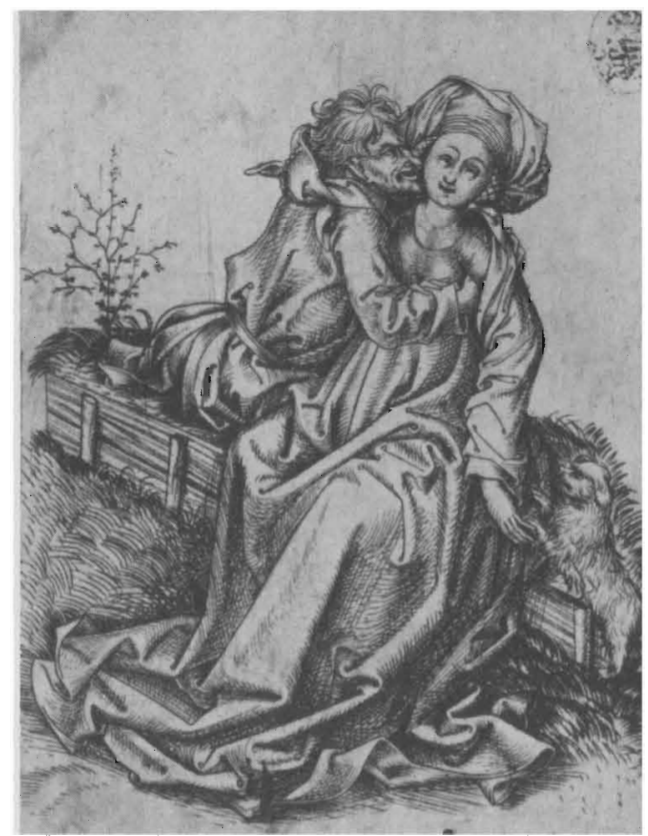


Old Man and Young Daughter with Antichrist

Attributed to Thomas Fröschlein of Reutlingen

1494; woodcut; 135 x 82 mm. Muther 1972, p. 457, pl. 154.

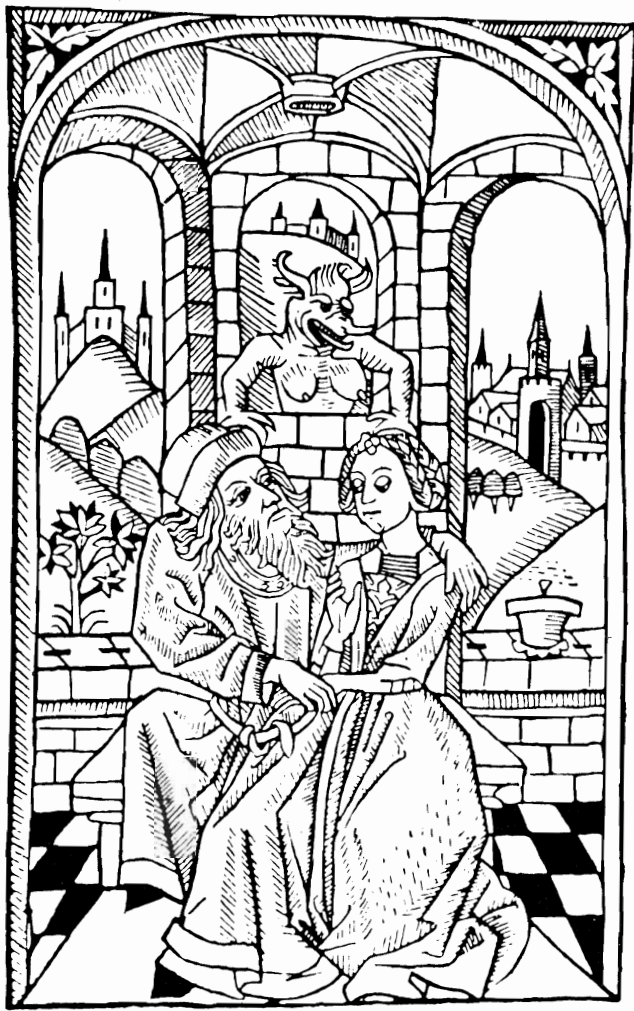

Old Man and Young Daughter with Antichrist German

Woodcut. Musper 1970. p. 8, leaf 2r-b.

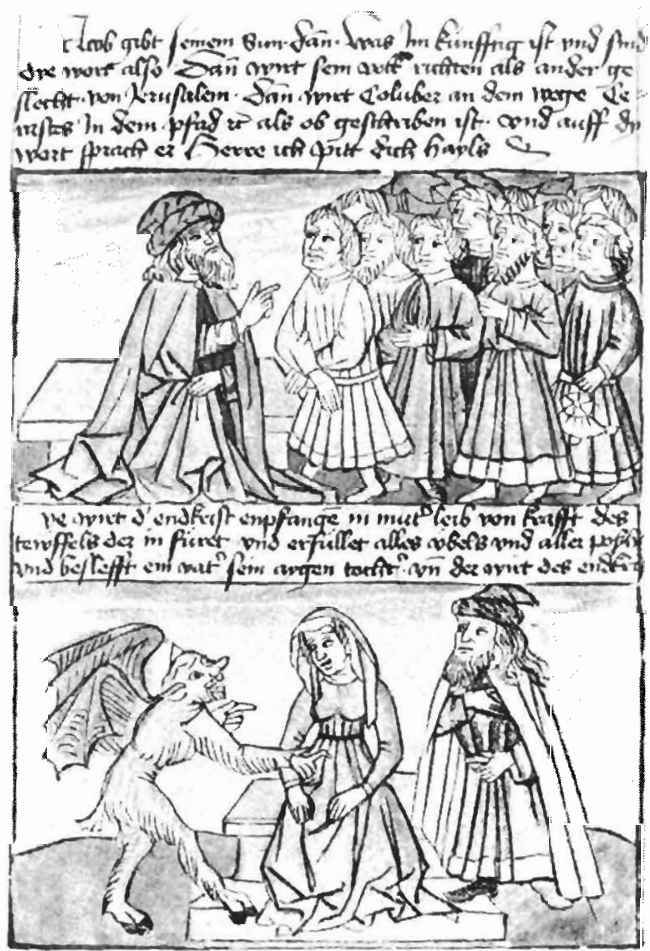


Old Wife and Young Fool

Albrecht Dürer (1471-1528, Nuremberg)

1494; woodcut from Sebastian Brant's Narrenschiff (Johann Bergmann von Olpe, Basel, 1494). Kurth 1963, fig. 54. Brant 1962 ed., p. 182. Winkler 1951, pl. 21. See text fig. 32 .

Old Man and Young Woman

Albrecht Dürer

Ca. 1495; engraving; 150 x $139 \mathrm{~mm}$. B.7.103.93;

H.7.73. Strauss 1972, pl. 5. Panofsky 1971 a, pp. $68 f$. Talbot 1971, p. 113, no. 3; fig. 3. Springer 1867, pp. $186,187,206$. Thausing 1884 , vol. 1, pp. 210 f. See text fig. 1 .

Will in Munzbelustigung, vol. III, p. 164, wrote that Berthold Tucher and Anna Pfinzing of Nuremberg are pictured. Tucher, in the year 1365, after the death of his first wife, had tossed a coin whether to take holy orders or whether to marry again. The decision was for the second alternative. He then according to the story, sat down in front of Pfinzing's house until one of his three daughters came out to marry him.
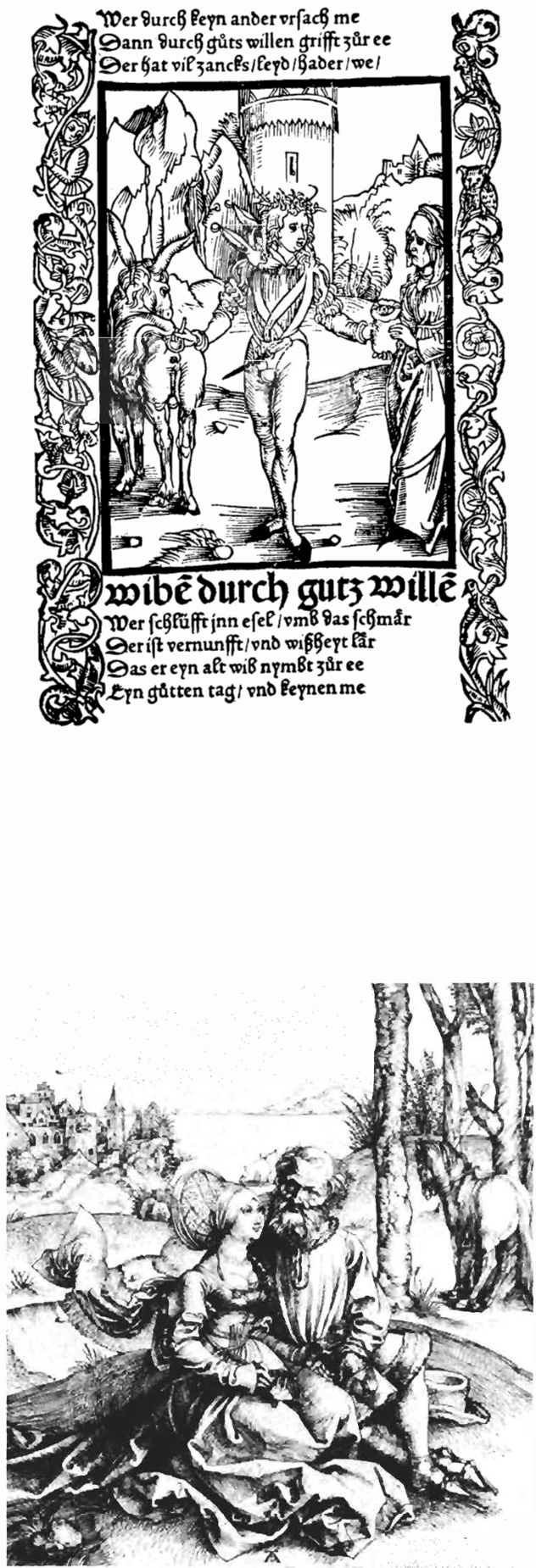
1497 or earlier; engraving from Meckenem's late series of twelve scenes of daily life; ca. 159 x $107 \mathrm{~mm}$. B.7.267.171; L.9.392.502. Shestack 1967-68, no. 236, after Lehrs assigns to this engraving a terminus ante quem of 1497 , when the print was copied in reverse in a Spanish edition of Boccaccio; fig. 236. Warburg 1930, pl. 23. Geisberg 1905, pl. 404. See text fig. 60.

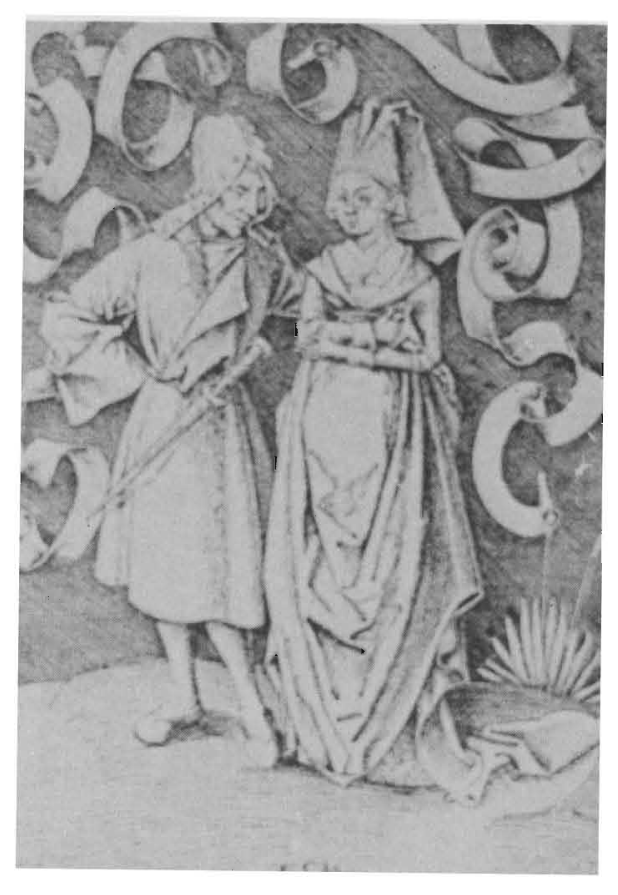

61 Old Man and Young Woman with Demon and Putto Accomplices

Bernhard Strigel (1461-1528, Memmingen in Swabia)

1502; chiaroscuro drawing on slate-gray paper, heightened in white and red; $225 \times 176 \mathrm{~mm}$. Berlin, Kupferstichkabinett, Kunstmuseum. Rettick 1967, p. 104, reads the date as as 1503 , those below as 1502 . Shestack 1966, p. 22, fig. 2 . Otto 1964, p. 108, no. 169; fig. 169. Parker and Hugelshofe 1 1925, p. 30. Bock and Friedländer 1921, p. 87, no. 4256. See text fig. 63.

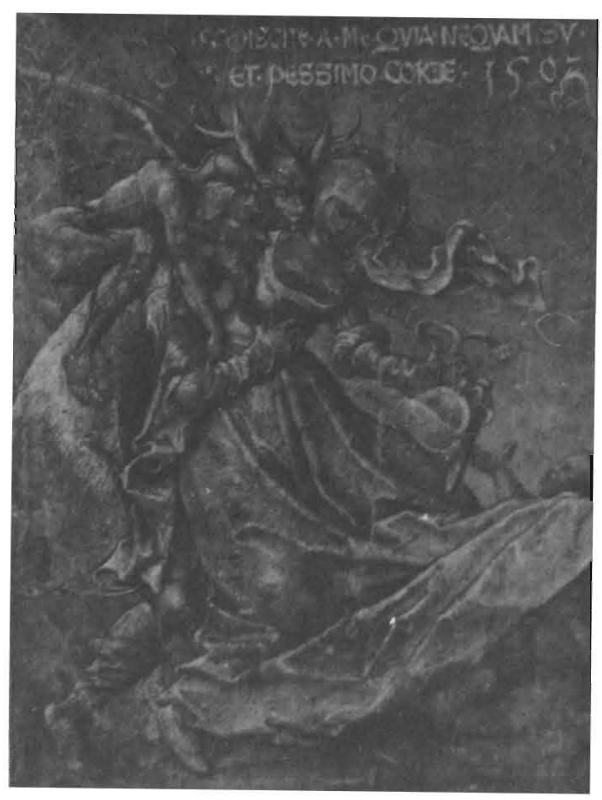

This drawing is the first Unequal Couple to have come down to us in a non-reproductive medium. It was probably executed as a finished work of art. The finished quality of this work and of chiaroscuro drawings in general is suggested by their use of colored paper, their heightening in colors including gold, and their precise draughtsmanship. Margaretta Salinger considers Baldung's drawings-probably his chiaroscuro drawings-"not mere preparatory studies but finished works of art." Otto Fischer specifically mentions that Baldung's chiaroscuro drawings from his Freiburg years (1512-16) are often seen as works existing for themselves because of their completeness. This drawing's earlier dating, by some ten years, should present no problem in its acceptance as a finished work. Independent drawings are thought to have existed even in the fifteenth century. R. W. Scheller, for example, sees Jacopo Bellini's drawings in a similar light, as "a basically new idea of creating a graphic work of art for its own sake." 281 
Old Man and Young Woman (copy in reverse of no. 59) Marcantonio Raimondi (ca. 1480-ca.1530, born Bologna)

Before 1505; engraving; 147 x 138 mm. B.14.414.650. Durer through other Eyes 1975, pp. 30, 31; p. 80, fig. 13 (detail). Delaborde 1888, p. 271, calls this engraving among the first, if not the very first, of Marcantonio's copies of Dürer's prints. This includes his Life of the Virgin Series, which dates about 1505 . Warburg. See text fig. 76.

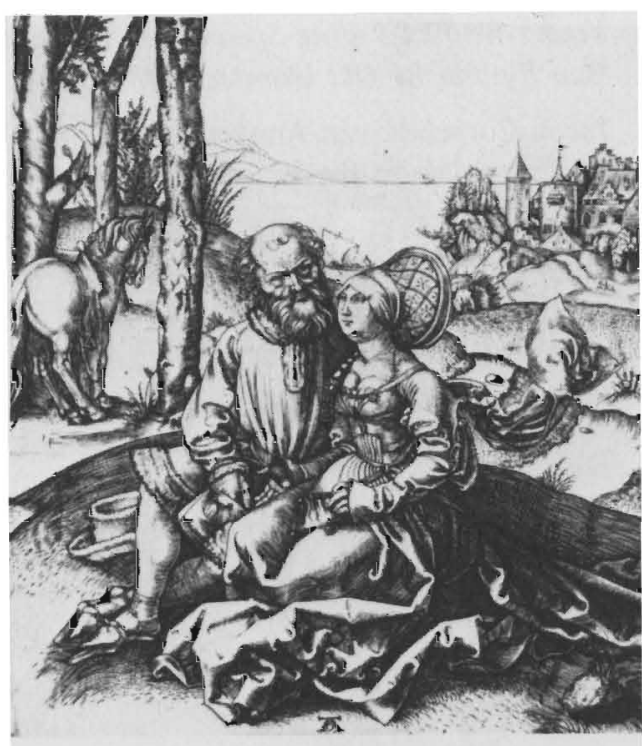

Attributed to Jörg Schweiger (goldsmith and stamp cutter, born Augsburg, active in Basel from 1505, died 1533/34)

Ca. 1510; drawing, probably for goldsmith work. ${ }^{282}$ Basel, Kupferstichkabinett, Kunstmuseum, Inv. No. U.VIII. 55. See text fig. 61 . 
64 Young Woman Selling Spectacles to Old Man and Young Man Embracing Old Woman, with a Fool

Jacob Cornelisz. van Amsterdam (ca. 1470-1533, active in Amsterdam in the sixteenth century)

Soon after 1511; panel; 470 x $350 \mathrm{~mm}$. Groningen, Museum van Oudheden. Gerson 1950, p. 48 (excellent reproduction). Hoogewerff 1939, vol. 3, p. 534. Steinbart 1929, p. 220, dates the painting; fig. 12 . DIAL no. 49598. See text fig. 33 .

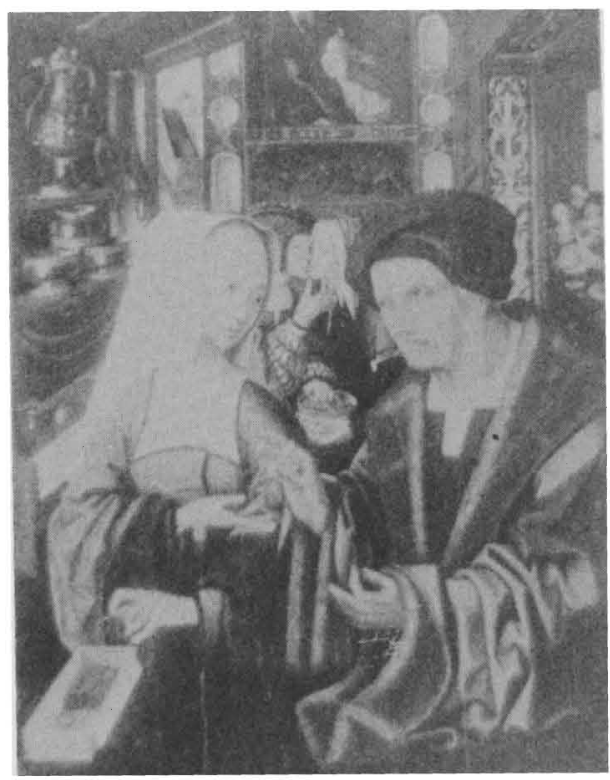

65 Old Man and Young Woman, Old Woman and Young Man with Fool Indoors (copy of no. 64)

After Jacob Cornelisz. van Amsterdam.

not illustrated

Panel; 460 x 320 mm. J. Goudstikker Art Dealer, Amsterdam 1936 from Freund Collection, Amsterdam, 20 February 1906. Friedländer 1936-47, vol. 3, p. 197, no. 288.

66 Old Man and Young Woman, Old Woman and Young Man with Fool Indoors (copy? of no. 64)

not illustrated

After Jacob Cornelisz. van Amsterdam

Panel; 450 x $320 \mathrm{~mm}$ or 470 × $350 \mathrm{~mm}$. Art Dealer, Berlin 1922. Friedländer 1936-47, vol. 3, p. 197, no. 288. 
Hans Holbein the Younger (1497-1543, born Augsburg, active in Basel, later in England)

1515; drawing in Myconius's copy of Erasmus's Praise of Folly published in that year. Basel, Kupferstichkabinett. Kunstmuseum. Landolt 1972, fig. 54. Dated by Von Mandach and Koegler [1942], p. LIII, pl. 69. See text fig. 37.

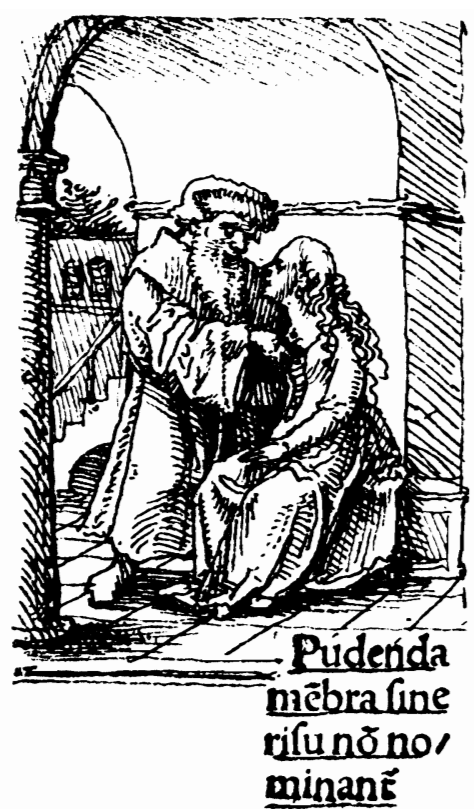

Old Woman, Young Man and Demon Accomplice

Niklaus Manuel

Ca. 1515; pen drawing in gray-black ink; $191 \times 289 \mathrm{~mm}$. Basel, Kupferstichkabinett, Kunstmuseum. Landolt 1972, fig. 54. Dated by Von Mandach and Koegler [1942], p. LIII, pl. 69. See text fig. 37.

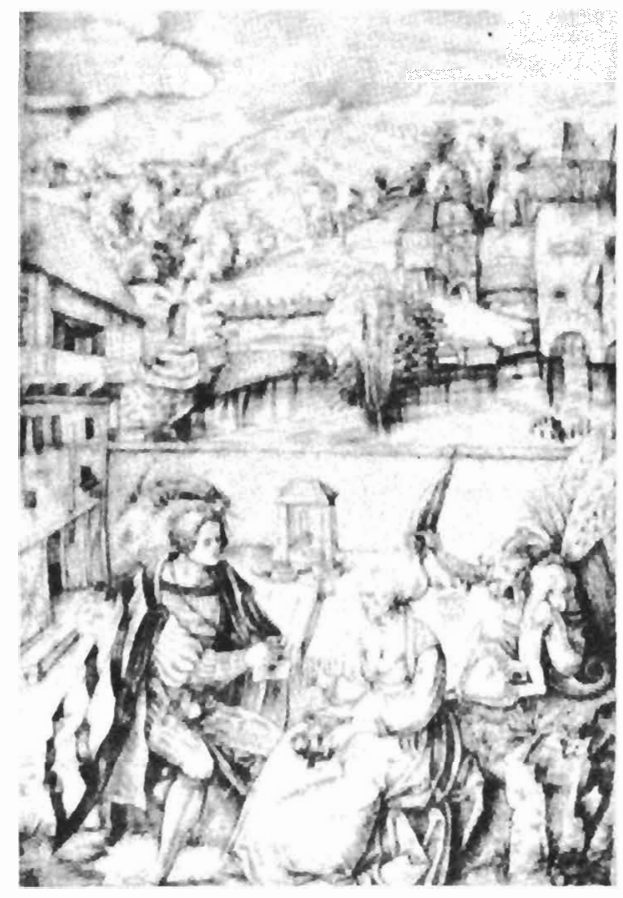


Hans Wandereisen (active ca. 1535-48?, Nuremberg)

1519; woodcut printed by Georg Erlinger at Bamberg; $210 \mathrm{x}$ $137 \mathrm{~mm}$. B.1.6.940. Geisberg 1974, vol. 4, no. 1437. Bolte 1895, pp. 141-43. See text fig. 3.

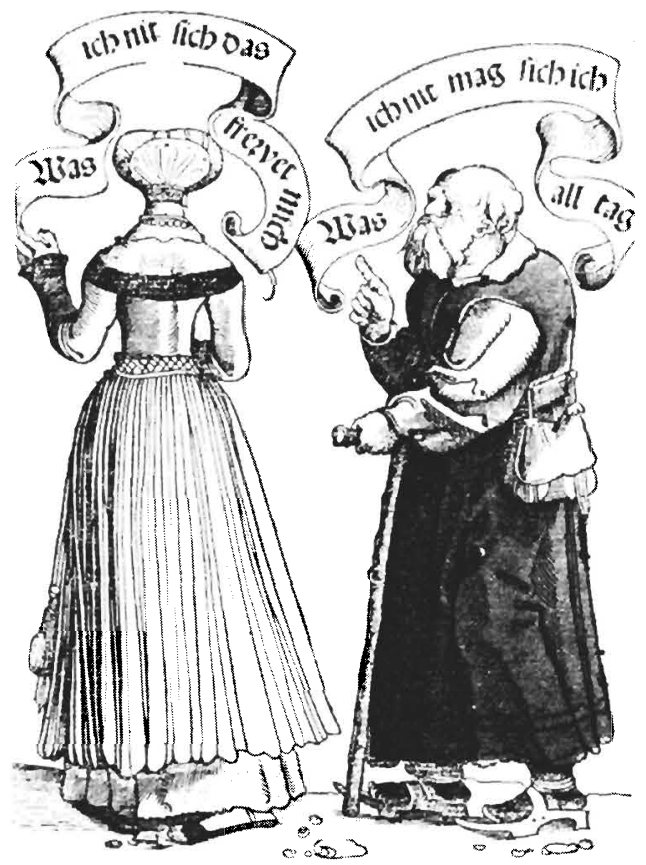

70 Young Woman Flattering Old Man by Tickling his Nose with a Reed

Hans Weiditz the Younger (born before or ca. 1500, active first third of the sixteenth century; generally identified with the Petrarca Master who was active in Augsburg)

Ca. 1520; woodcut from the 1532 edition of Petrarch's Von der Artzney bayder Glueck, published in Augsburg, one of the most widely read books of the time. ${ }^{283}$ Scheidig 1955 , p. 123, with illustration. See text fig. 34.

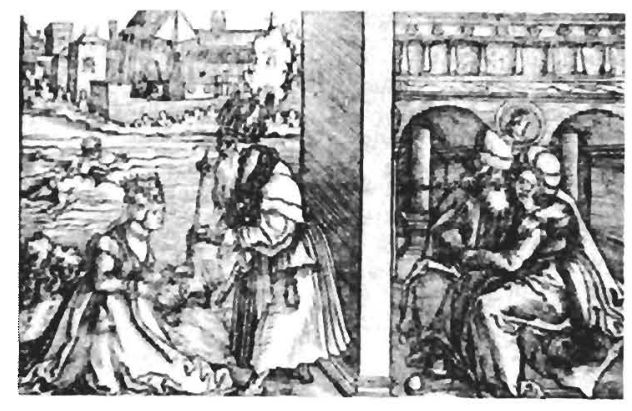

Old Woman and Young Man

Hans Weiditz the Younger

Ca. 1520; woodcut from the 1539 edition of Petrarch's Von der Artzney bayder Glueck, published in Augsburg. Scheidig 1955, p. 122, with illustration.

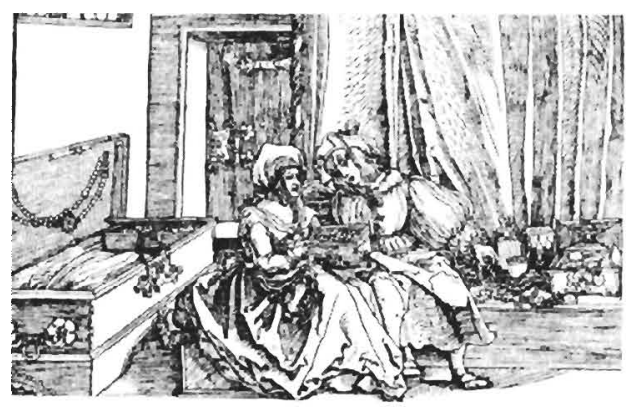


72 Old Woman and Young Man with Six Onlookers: The Marriage Contract

After Quinten Massys

Ca. 1530; canvas; $550 \times 910 \mathrm{~mm}$. Formerly Vienna Art Market. Probably Berlin, Lepke Collection 30 April 1929 (540 x $880 \mathrm{~mm})$. Friedländer 1967-76, vol. 7, Add. 192. Larsen 1950, p. 174. Friedländer 1947, p. 118, fig. 13; p. 119. Witt.

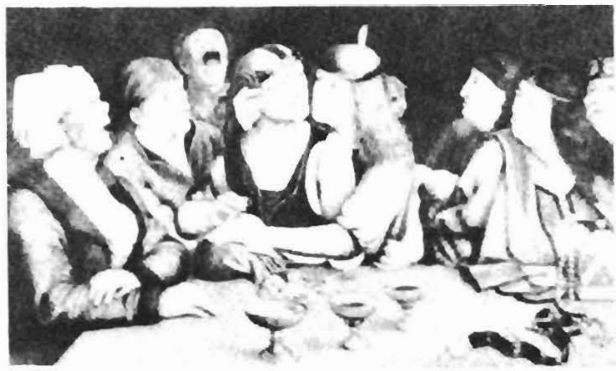

This painting, which is known in five versions (nos. 72-76), is believed to have originated in the circle of Quinten Massys about 1530. The work was inspired by Leonardo drawings that date from the 1490s not only for the Unequal Couple (see nos. 5 and 6), but also for the old woman in profile at the left and the two figures on either side of the central couple (illustrated below). ${ }^{284}$ Two paintings of this theme were listed in the 1709 and 1710 inventories of the collection of the French king. One was called a Leonardo, the other a Wuinten Massys. Larsen believes that the Leonardo may be the Smith Collection version (no. 73) and the Massys that of the Palitz Collection (no. 74). ${ }^{285}$ The attribution of nos. 73 and 76 to Bernardino dei Conti should be questioned since he died in 1522 and the paintings probably date somewhat later, about 1530 or soon thereafter.
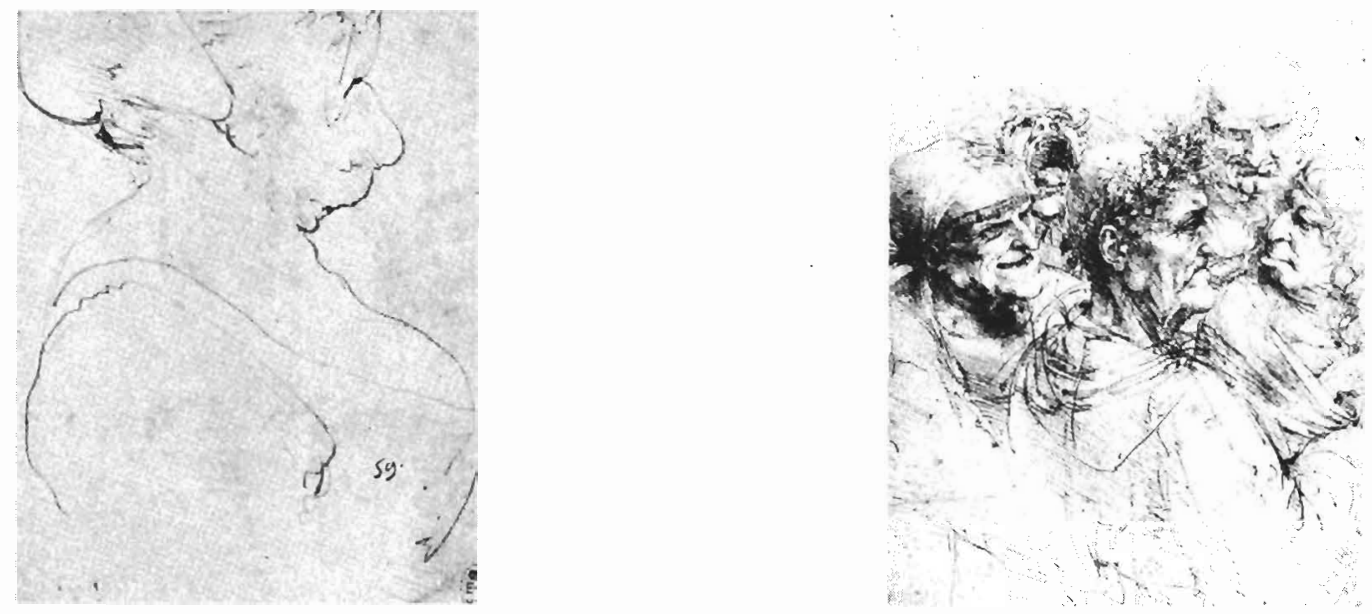
73 Old Woman and Young Man with Six Onlookers (copy of no. 72)

Circle of Leonardo, variously attributed to Leonardo and his follower Bernardino dei Conti (active 1490-1522, Milan) Ca. 1525-50; $699 \times 896$ mm. W. Thomas Smith Collection. Larsen 1950, p. 174. Witt. See above, no. 72.

74 Old Woman and Young Man with Six Onlookers (copy of no. 72 and nearly identical to no. 75 , which omits one figure)

Flemish(?)

Ca. 1530; panel; 559 x 839 mm. New York, Clarence Palitz Collection. Valentiner and Suida 1949, p. 105, no. 71; fig. 71. Krönig 1936, p. 174.

75 Old Woman and Young Man with Five Onlookers (copy of no. 74 omitting screaming[?] man to the left of center) Attributed to Lucas Cranach the Younger

Ca. 1525-50; panel; 559 × 845 mm. London, Alexander Arensberg Collection. New York, American Art Association, Roerich Museum Sale 26/8 March 1930̣. Witt.
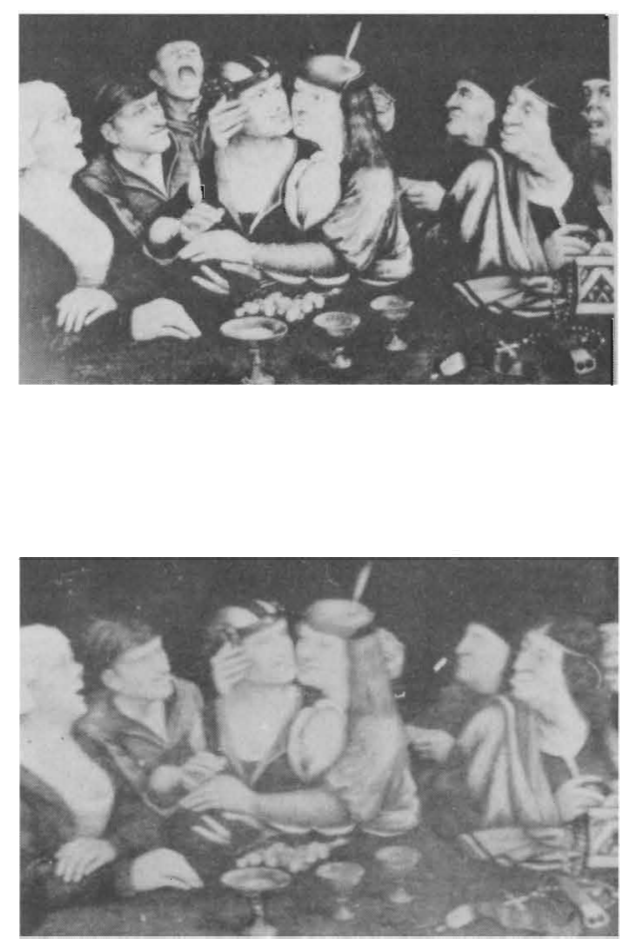

76 Old Woman and Young Man with Five Onlookers (weak copy of no. 72 omitting figure at far right)

Circle of Leonardo, variously attributed to Leonardo and Bernardino dei Conti

Ca. 1525-50. W. Thomas Smith Collection. Venice, Collection of Guido Minerbi Co., 1921. Witt.

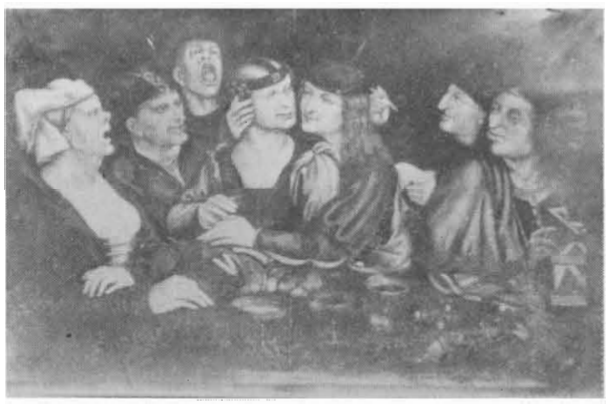


Old Man and Young Woman with Two Young Women Nearby

Lucas Cranach the Elder

Ca. 1530; panel; $840 \times 116 \mathrm{~mm}$. Paris, Private Collection. Formerly Sotheby's, Sale 12 December 1973, earlier Aldwick, Craigwell House (London auction 2 August 1932, lot 126). Burlington Magazine vol. 115, pt. 4 (Nov. 1973): p. XXV (Sotheby advertisement). Friedländer and Rosenberg 1932, p. 72, no. 237; fig. 237.

The Payment: Unequal Couple with Hunting Gear

Lucas Cranach the Elder

1532; panel; 108 x 119 mm. Stockholm, National Museum. Schade 1974, pl. 173. Friedländer and Rosenberg 1932, no. 236 , fig. 236 . Göthe 1887 , p. 60 , no. 258 . See text fig. 52.

Old Man Holds Young Wife on Leash, Young Man Holds Old Wife on Leash: The Old Wives' Horse Fair (Warning against Unequal Marriage)

Erhard Schön (ca. 1491-1542, Nuremberg)

Ca. 1533; woodcut illustration to a now-lost poem by Hans Sachs entitled The Old Wives' Horse Fair; 139 x 244 mm. Die Welt des Hans Sachs 1976, p. 133, no. 135. Geisberg 1974, vol. 3, no. 1129. Schmidt 1930, no. 1182. Röttinger 1925, no. 187. See text fig. 82.

Old Woman and Young Man, Old Man and Young Woman, and Two Young Lovers

Lucas Cranach the Younger

See the commentary for no. 72. Ca. 1540; panel; $735 \mathrm{x}$ $1210 \mathrm{~mm}$. Dresden, Staatliche Kunstsammlungen. Koep. plin and Falk 1974-76, vol. 2, p. 570, no. 469; p. 572, fig. 296. Woermann 1889 , no. 1936. For the realtion of

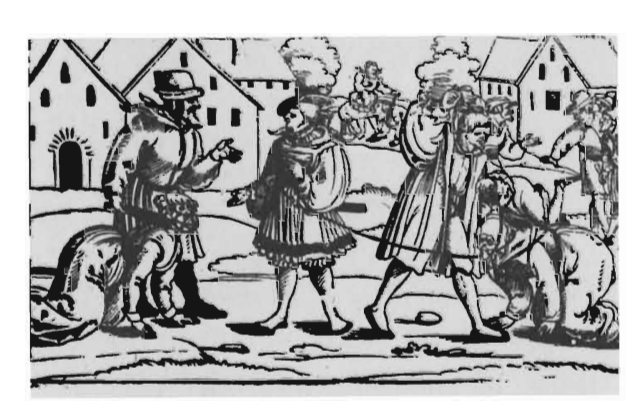
the pug-nosed woman to a Leonardo drawing, see no. 72 .
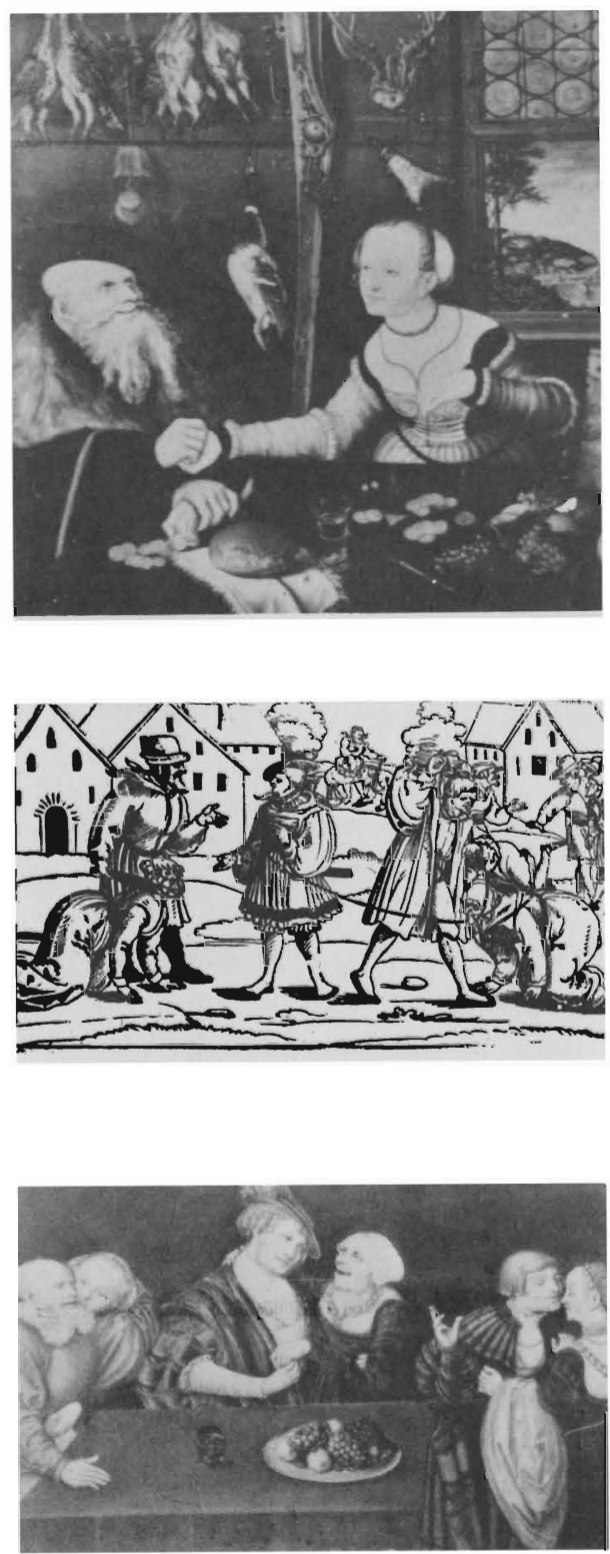
81 Old Man and Young Woman with Another Young Woman School of Lucas Cranach the Elder

London, T. Harris 1932. Witt.

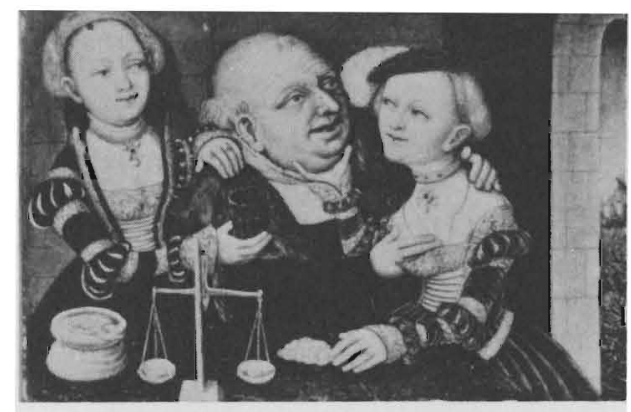

82 Old Man and Young Woman, Two Young Women, and Two Young Lovers

Lucas Cranach the Elder

Munich, von Bissing Collection 1910. Witt. Cf. no. 80 .

83 Old Man and Young Woman, Two Young Women, and Two Young Lovers (weak variant of no. 82)

Halle, Bodenburg Collection. Witt.
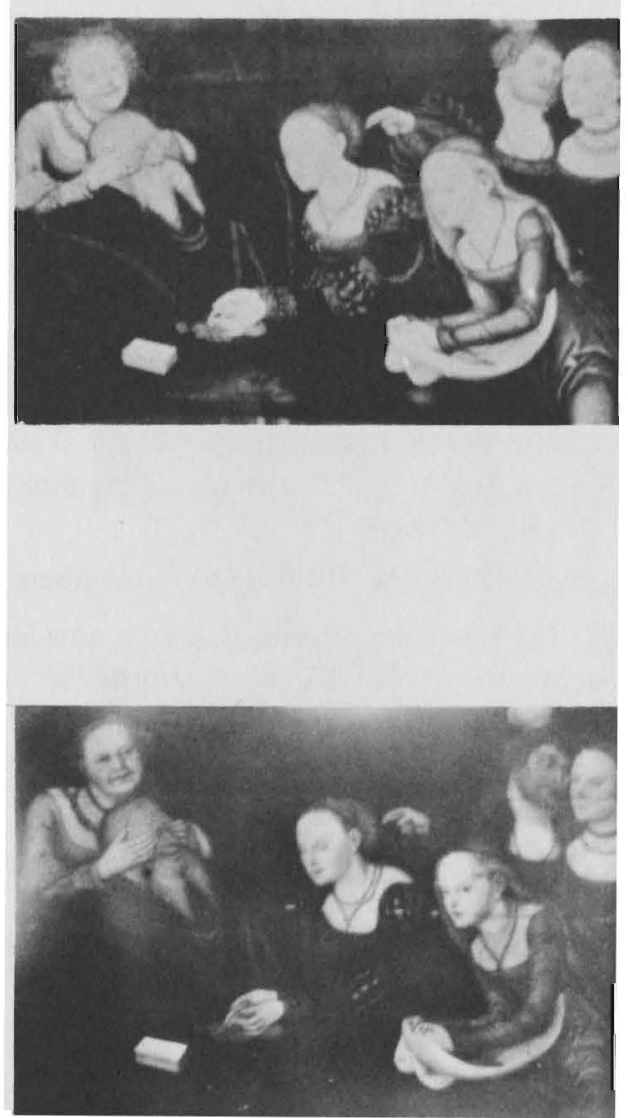
84 Old Man and Young Woman (for related half-lengths, see nos. 53 and 54)

School of Lucas Cranach the Elder

London, Koetser 1951. Witt.

\section{LOVE TRIANGLES:}

85 Love Triangle with Symbols of Pleasure and Transience Urs Graf (ca. 1485-1527/28, Basel)

Ca. 1511; woodcut; 324 x $223 \mathrm{~mm}$. London, British Museum (unique). B.7.unno. Koegler 1947, p. 180. Major and Gradmann [1942], fig. 127, p. 37, no. 137. See text fig. 6 .

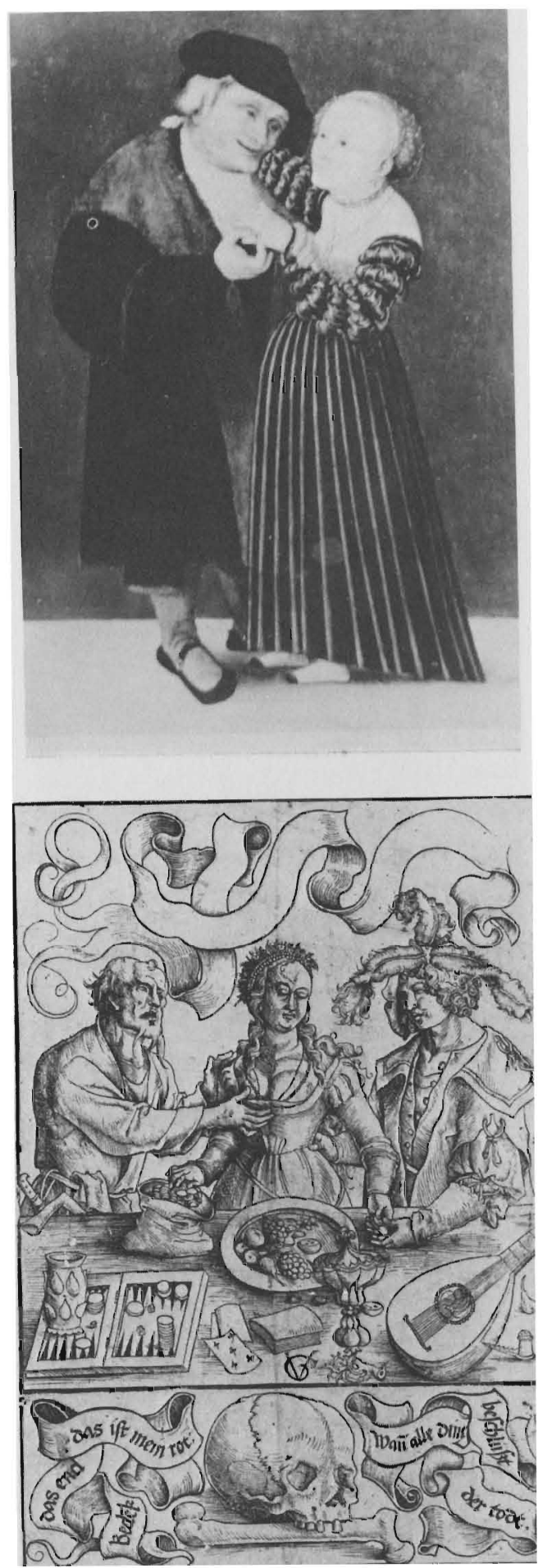

Major and Gradmann date this woodcut about 1511, as assigned by Parker. The work should date no later than 1512, the last year that the artist employed the borax box as part of his signature, included here at middle right. Major and Gradmann suggest that the woodcut does not reflect an invention of Graf, since the clarity of design and figure types are certainly uncharacteristic of that artist. It may, according to these authors, be a pastiche that had Graf's monogram added to it. 
Alsatian or Swiss

1559 or 1565; woven cushion cover. Formerly Figdor Collection, Vienna. Göbel 1933, vol. 1, pt. 3, fig. 164a. Von Falke 1930, vol. 1, fig. 12. Kurth 1926, vol. 1, p. 121. See text fig. 78.

Ca. 1512; panel; 302 x 392 mm. Castagnola, ThyssenBornemisza Collection, Schloss Rohoncz Foundation. Formerly The Hague, G. B. Huiskamp, Dealter. Earlier Dunsany Castle, The Lady Dunsany (sold 1971 Christie's). Parshall 1974, p. 98 dates the painting. Fried. länder 1967-76, vol. 7, pl. 111, Add. 181. Middeleeuwse Kunst 1958, p. 109, no. 130. DIAL no. 17076. See the two copies of this painting (nos. 88 and 89). See text fig. 41.

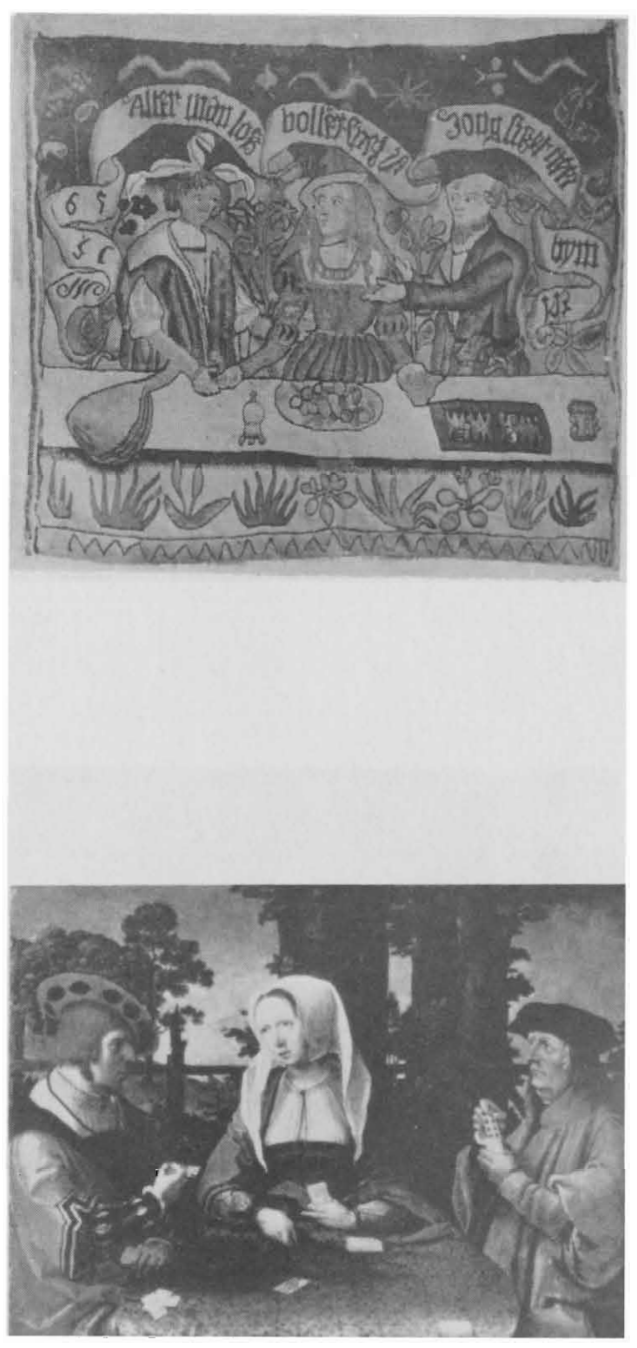

After Lucas Van Leyden

(Copy of no. 87); panel; $515 \times 425 \mathrm{~mm}$. London, Private Collection. 
Love Triangle in a Card Game Outdoors (weak copy of no. 87)

After Lucas van Leyden

Ca. 1512; panel; $420 \times 510 \mathrm{~mm}$. Eindhoven (Netherlands), the Late Dr. A. F. Philips Collection. Formerly Art Market, Amsterdam. Friedländer 1967-76, vol. 10, p. 87. cites the present location; pl. 111, Supp. 171. Middeleeuwse Kunst 1958, p. 109, under no. 130. Friedländer 1924-37, vol. 14, p. 122, gives the Amsterdam location, measurements and date.

Love Triangle with Old Woman

Niklaus Manue!

Ca. 1517; pen drawing heightened in white on brick-red paper. Basel, Kupferstichkabinett, Kunstnuseum. Eisler [1975], pl. 69. Mandach and Koeg]er [1942], p. LIV, date the work; pl. 76, with description. Sce text fig. 62.

\section{Love Triangle}

French

Ca. 1520; gold filigree and enamel hat omament; diameter 57 mm. New York, Robert Lelıman Collection, Metropolitan Museum of Art. Secular Spirit 1975, p. 88, no. 94, with illustration.
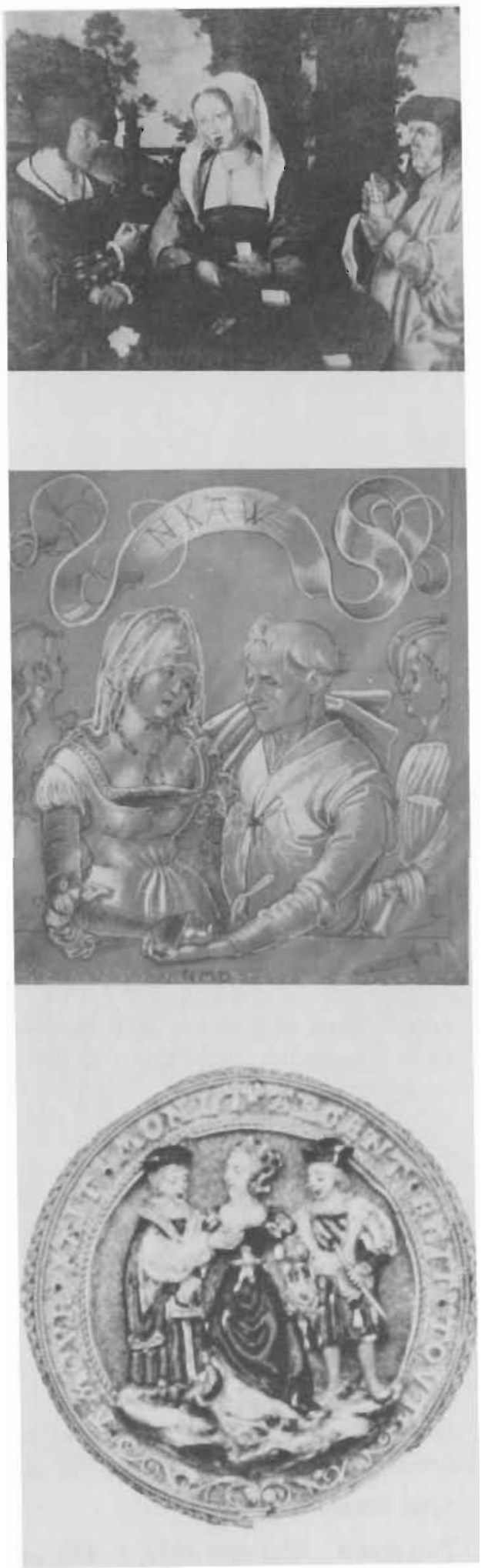
After Lucas van Leyden

Ca. 1520-30; etching; $183 \times 137$ mm. B.7.unno; H.10.244.99;

P.3.7. Bolte 1895 , p. 146. Warburg. See text fig. 43.

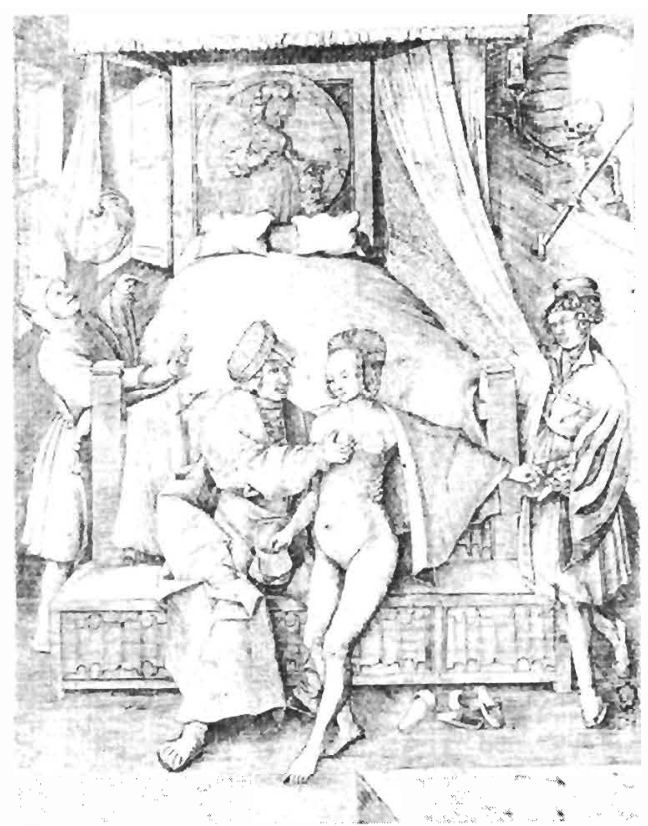

The composition, with a woman seated at the foot of a bed addressing a man to the left front, relates in form to a pen drawing by Urs Graf dated from about 1511 to $1516 .{ }^{286}$ Although Hollstein lists the print as an engraving, the regular graphic means suggest that it is an etching. Passavant describes a curled piece of paper marked with an L, Lucas's monogram, depicted on the floor. But it is not included in the impression in Oxford, the only one known to me.

93 Love Triangle in Bedroom with Fool, and Anamorphic Lewd Love Triangle Inscribed "Out You Old Fool" "“Aus du alter tor')

Erhard Schön

Ca. 1535; woodcut; $155 \times 758 \mathrm{~mm}$. B.9.151.2. Schuyt and

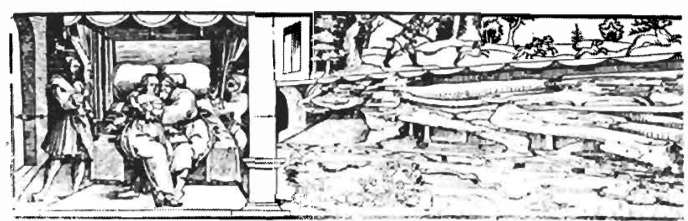
Elffers 1976, fig. 9. Baltrusaitis [1955], p. 14, pl. IIc. Röttinger 1925, p. 453, no. 204. Fuchs 1906, p. 180. See text fig. 44.

94 Love Triangle in Bedroom with Fool, and Anamorphic Lewd Love Triangle (copy of no. 93 in fragment)

After Erhard Schön

not illustrated

Two sheets. Röttinger 1925, p. 453, under no. 204. 
Love Triangle with Old Woman and Fool

Frans Crabbe van Esplegem (The Crayfish Master, ca. 14801552, Malines

Ca. 1525-35; engraving; $200 \times 140$ mm. H.5.94; P.3.20.46; W.1.352.46. Phopham 1935, p. 99, and 1935a, p. 209. Van Marle 1931-32, vol. 2, p. 458, fig. 490.

Hollstein accepts the attribution to Frans Crabbe, though Popham does not, saying that it is probably German and "recalls in no way Crabbe's design or technique." See text fig. 45 .

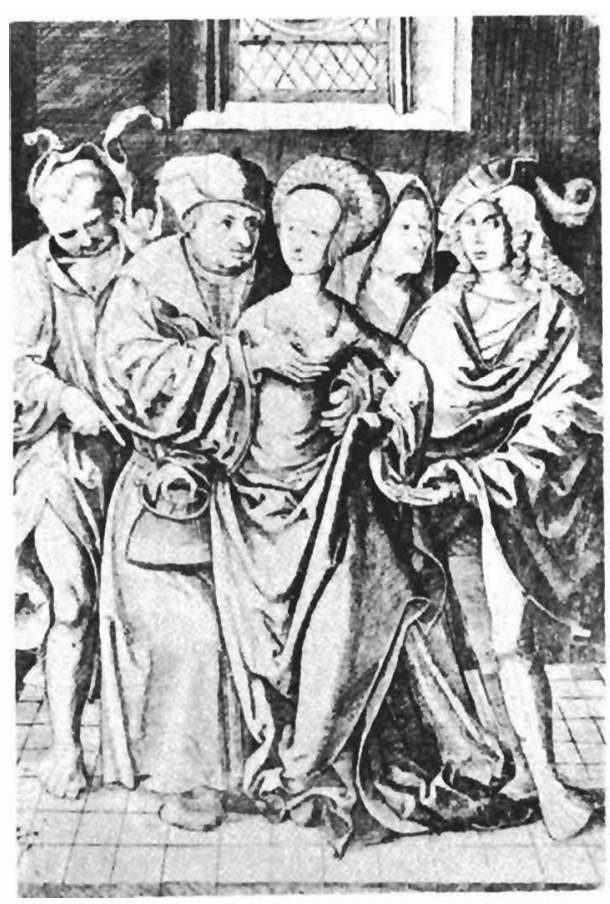

Love Triangle with Chastity Belt and Key

Nuremberg

Ca. 1525-30; woodcut. P.3.211.282. Coupe 1967, pl II. Van Marle 1931-32, vol. 2, p. 456, fig. 488. Fuchs 1906, p. 181. Bolte 1895 , p. 145 . See text fig. 47.

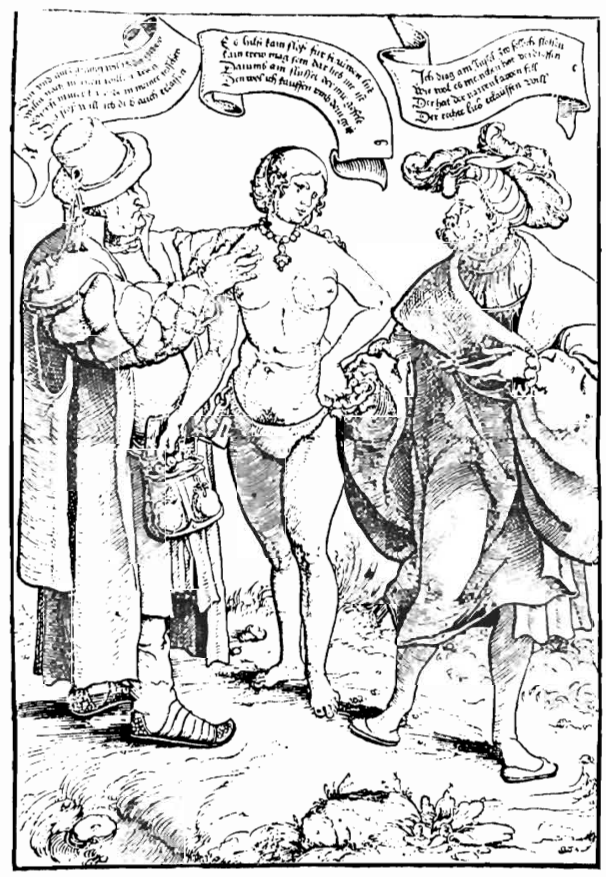


97 Love Triangle with Chastity Belt and Key (variant in reverse of no. 96)

Erhard Schön

Ca. 1525-30; woodcut; diameter ca. $67 \mathrm{~mm}$. Röttinger 1925 , p. 208, no. 312. Fuchs 1906, p. 180. Bolte 1895 , p. 145 , n. 1 . See text fig. 48.

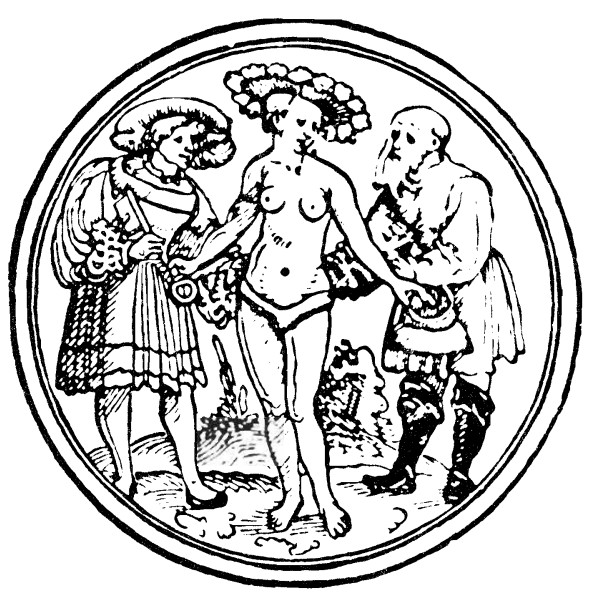

98 Love Triangle with Chastity Belt and Key (variant of no. 96)

\section{Nuremberg}

Ca. 1530 or later; colored woodcut. Fuchs 1906, illustrated p. 57.

The costume suggests a date later than the period under consideration here (ca. 1470-1535), possibly late in the sixteenth century or even the nineteenth.

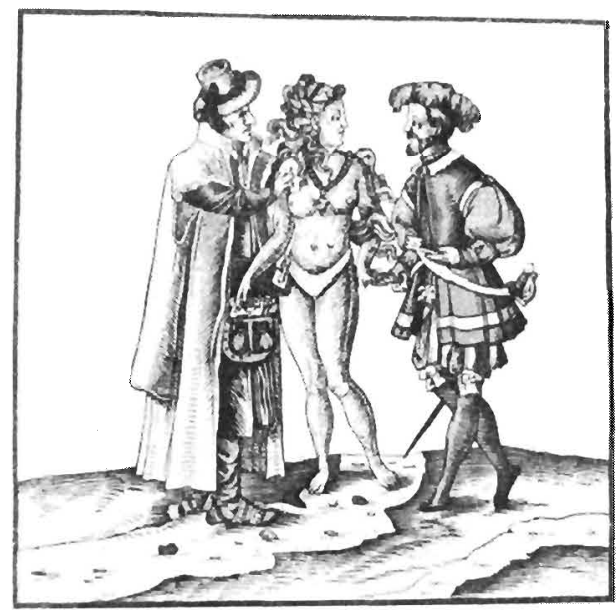


Love Triangle with Chastity Belt and Key with Old Man on Horseback (related to nos. 96-98)

Erhard Schön

Ca. 1530; woodcut playing card. Schmidt 1930 , p. 224, no. 1311.
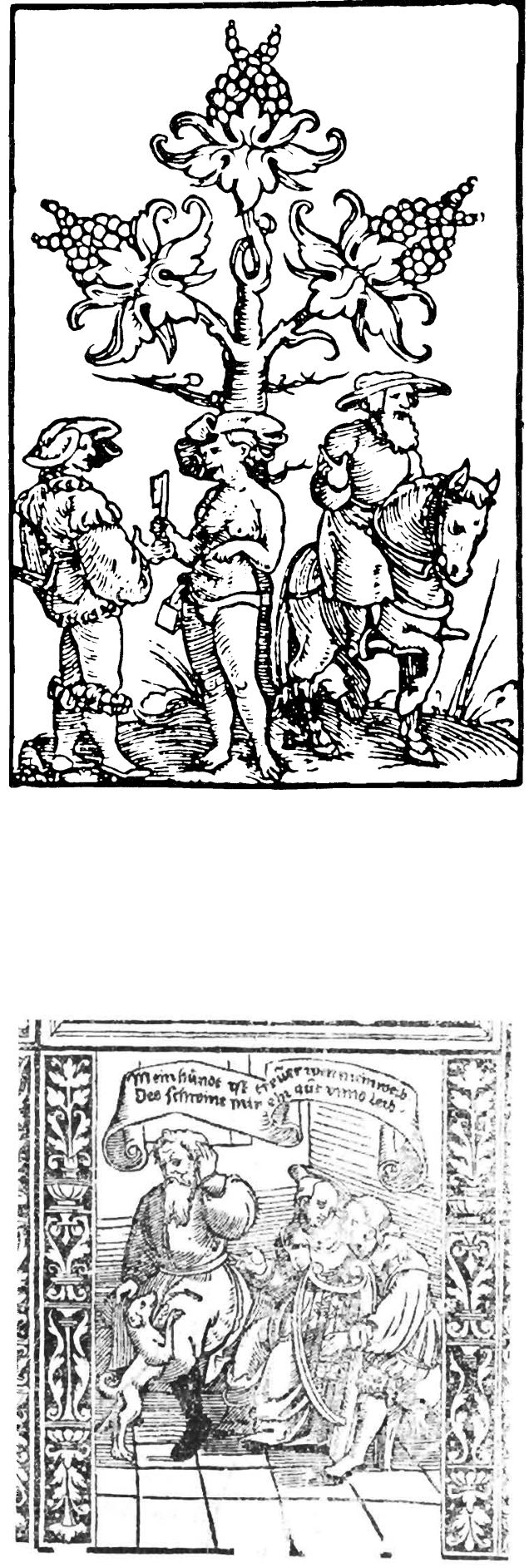


\section{QUESTIONABLE LOVERS:}

101 Old Man, Young Woman

Master W B (active ca. 1500, Middle Rhine around Mainz)

Ca. 1485-87; engravings; 138 x $88 \mathrm{~mm}$.

L.3.2 and L.4; P.2.263.58. Shestack 1971, p. 51 , fig. 41 , and p. 52 , fig. 2 , dates the engravings. Lehrs 1969, figs. 449 and 450.

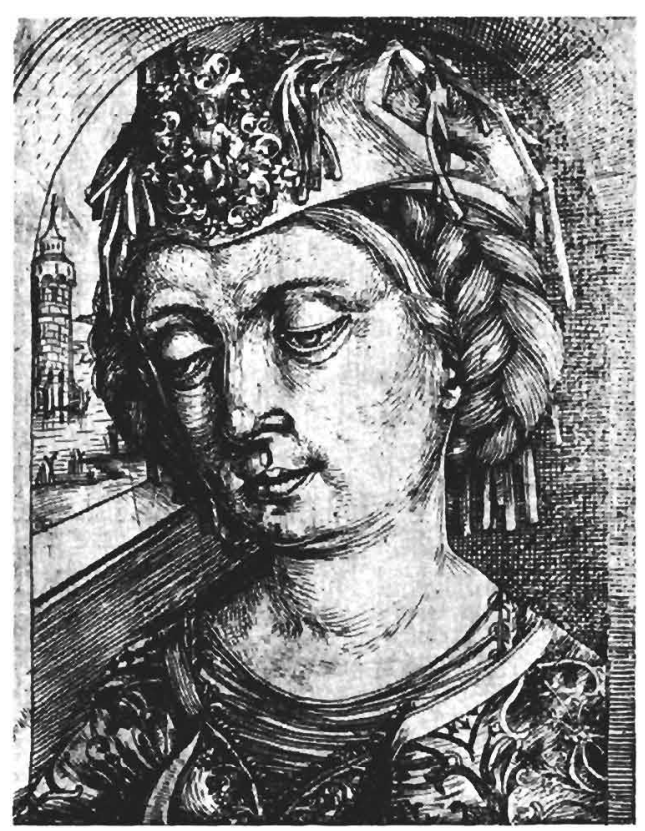

102 Old Man, Young Woman

Master W B

Ca. 1485-87; engravings; $137 \times 90 \mathrm{~mm}$, $116 \times 87$ mm. L. 1; P.2.270.61. Shestack 1971 , p. 53, figs. 44 and 45 , dates the engravings. Lehrs 1969, figs. 451, 452.

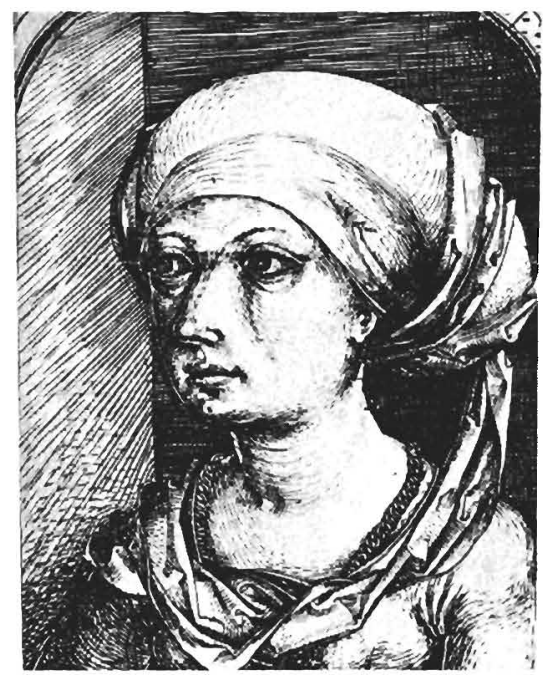

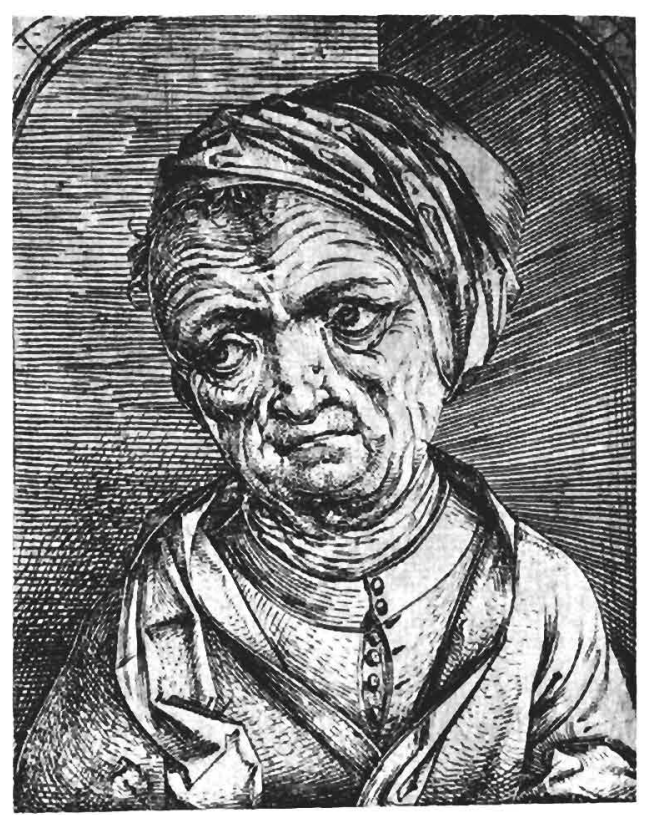

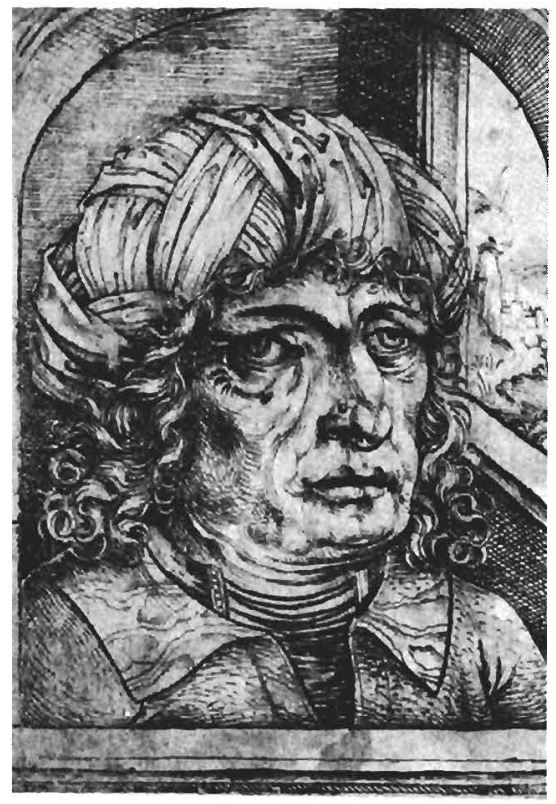


German

Late fifteenth century or nineteenth century: silver medallion engraved in niello; $\phi 49 \mathrm{~mm}$. Richmond, Virginia Museum. Wilk 1973, pl. xviii, fig. 9. The work is assigned by the Richmond Museum to fifteenth-century Germany. Authorities from the Museum für Kunst und Gewerbe, Hamburg, and Badisches Landesmuseum, Karlsrube, lean toward a nineteenth-century attribution.

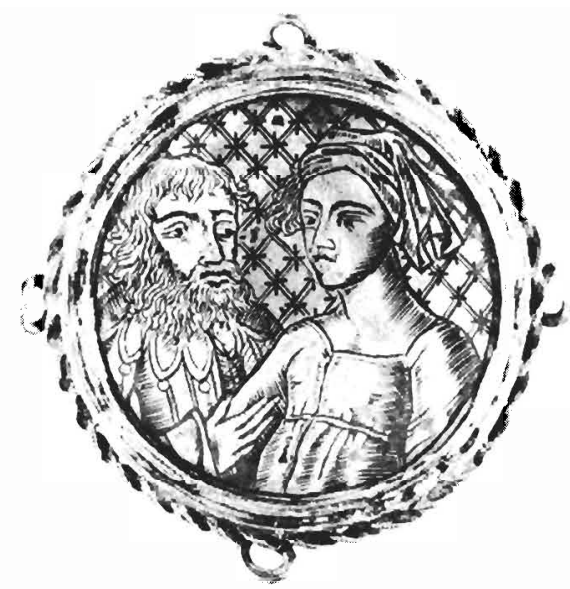

104 Old Man and Young Woman

Monogrammist d H (Nuremberg School, early sixteenth century)

1509; paper on panel; $190 \times 150 \mathrm{~mm}$.

Nuremberg, Germanisches Nationalmuseum.

Lutze and Wiegand 1937, plate vol., fig. 108.

See text fig. 79.

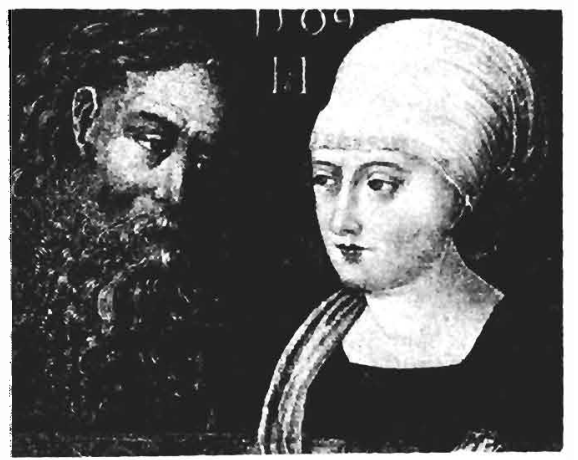

105 Old Woman and Young Man in Woman's(?) Dress

Circle of Lucas van Leyden

Ca. 1520-30; panel; $240 \times 180 \mathrm{~mm}$.

Netherlands, Private Collection. Dial no. 24629.

See text fig. 75 .

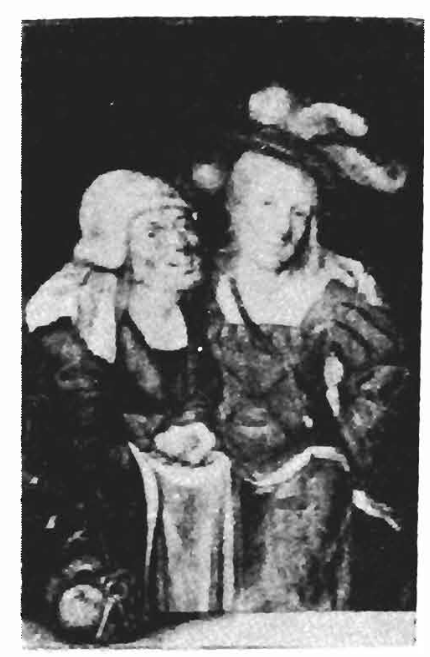

Love Triangle with Two Young(?) Men

Master HM (unknown monogrammist)

Ca. 1520-30; etching. Warburg.

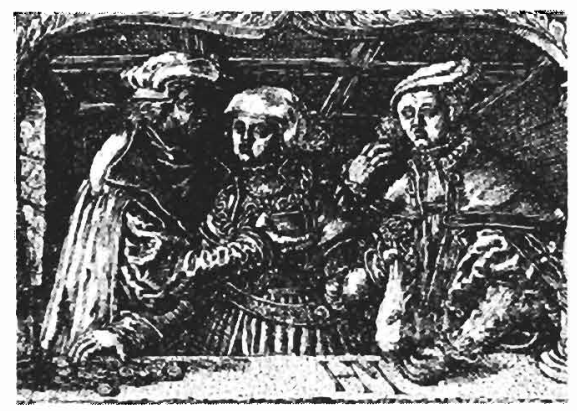


BIBLIOGRAPHY 


\section{ABBREVIATIONS}

B.

H.

H.

L.

N.

P.

\section{Schreiber}

W.

DIAL

RKD

Warburg

Witt

Z. I.

Bartsch, Adam. 1803-21. Le Peintre graveur. 21 vols. Vienna.

Hollstein, F. W. H. 1949-74. Dutch and Flemish Etchings Engravings and Woodcuts ca. 1450-1700. 19 vols. Amsterdam.

Hollstein, F. W. H. 1954ff. German Engravings Etchings and Woodcuts ca. 1400-1700. 12 vols. Amsterdam.

Lehrs, Max. 1908-34. Geschichte und kritischer Katalog des

deutschen niederländischen und französischen Kupferstichs im $X V$. Jahrhunderts. 9 vols. Vienna.

Nagler, G. K. 1966. Die Monogrammisten und diejenigen bekannten und unbekannten Künstler aller Schulen. Munich and Leipzig.

Passavant, J. D. 1860-64. Le Peintre-graveur. 6 vols. in 3. Leipzig.

Schreiber, W. L. 1926-30. Handbuch der Holz- und Metalschnitte des $X V$. Jahrhunderts. 8 vols. Leipzig.

Wurzbach, Alfred von. 1906-11. Niederländisches KünstlerLexikon. 3 vols. Leipzig and Vienna. 1906-11.

Decimal Index of the Art of the Lowlands

Rijksburo voor Kunsthistorisch Documentatie, The Hague

Warburg Institute, University of London

Witt Library, Courtauld Institute, University of London

Zentralinstitut für Kunstgeschichte, Munich 
A

Altdeutsche Meister aus der Staatlichen Kunsthalle Karlsruhe. 1964. 2d enlarged ed. Karlsruhe.

Andlaw, Franz Feiherr von. 1861. Die Frauen in der Geschichte. Ein historischer Versuch. 2 vols. in one. Mainz.

Anzelewsky, Fedja. 1970. The Drawings and Graphic Work of Dürer. New York.

Augustoni, Fabrizio, ed. 1972. Maestro del Libro di Casa. Maestri dell'incisione. Milan.

B

Bächtold, Hanns. 1914. Die Gebräuche bei Verlobung und Hochzeit mit besondrer Berlicksichtigung der Schweiz. Basel and Strasbourg.

Baltrusaitis, Jurgis. [1955]. Anamorphoses ou perspectives curieuses. Paris.

Beeh, Wolfgang. 1966. Eine spätgotische mittelrheinische Handschrift "Über die Liebe zu erwerben und die Liebe zu verschmähen." Kunst im Hessen und am Mittelrhein 6:53-82.

Bialostocki, Jan. 1959. “Opus Quinque Dierum”: Dürer's Christ Among the Doctors and its Sources. Journal of the Warburg and Courtauld Institutes 22:17-34. . 1976. Myth and Allegory in Dürer's Etchings and Engravings. Print Review 5:24-34.

Biermann, Georg. 1912. Die Gemäldesammlung des Baron Herzog in Budapest. Cicerone 4:417-34.

Bliss, Douglas Percy. 1928. Love Gardens in the Early German Engravings and Woodcuts. Print Collector's Quarterly 15:90-109.

Boccaccio, Giovanni. 1973 edition. The Decameron. Translated and with an introduction by G. H. McWilliams. Baltimore.

Bock, Elfried and Friedländer, Max J., eds. 1921. Staatliche Museen zu Berlin. Die deutschen Meister. Die Zeichnungen alter Meister im Kupferstichkabinett. Berlin.

Bolgar, R. R. 1963. The Classical Heritage and its Beneficiaries. Cambridge.

Bolte, Johannes. 1895. Bilderbogen des 16. Jahrhunderts. Tijdschrift voor Nederlandsche Taal- en Letterkunde 14:140ff.

Bosque, A. de. 1975. Quentin Massys. Brussels.

Bossert, Helmut Th. and Storck, Willy F. 1912. Das Mittelalterliche Hausbuch nach dem Originale im Besitze des Fürsten von Waldburg-Wolfegg-Waldsee. Leipzig.

Brant, Sebastian. 1962 edition. The Ship of Fools. Translation, introduction, and commentary by Edwin H. Zeydel. New York.

- 1964 edition. Das Narrenshiff. Edited by Hans Joachim Mähl. Translated by H.A. Junghaus. Stuttgart.

Bromwelle, Norman. 1955. Cleaned Pictures at Liverpool. Burlington Magazine 97: 352-54.

Bücher, Karl. 1910. Die Frauenfrage im Mittelalter. 2d enlarged ed. Tübingen.

Buchner, Ernst and Feuchtmayr, Karl, eds. 1924. Oberdeutsche Kunst der Spätgotik und Reformationszeit. 2 vols. Augsburg.

\section{C}

Campbell, Lorne. 1976. The Art Market in the Southern Netherlands in the Fifteenth Century. The Burlington Magazine 118:188-98.

Capellanus, Andreas. 1959 edition. The Art of Courtly Love. Introduction, translation, and notes by John Jay Parry. New York. 
Chaucer, Geoffrey. 1964 edition. Canterbury Tales. Edited by A. Kent and Constance Hieatt. New York.

Chudzikowski, Andrzej, ed. 1969. National Museum in Warsaw. Catalogue of Paintings, Foreign Schools. 2 vols. Warsaw.

Clark, Kenneth and Pedretti, Carlo. 1968-69. The Drawings of Leonardo da Vinci in the Collection of her Majesty the Queen at Windsor Castle. 2d edition. 3 vols. New York.

Clemen, Paul. 1930. Die Götische Monumentalmalerei der Rheinlande. Düsseldorf.

Coulton, George G. 1910. A Medieval Garner. Human Documents from the Four Centuries Preceding the Reformation. London.

Coupe, W. A. 1967. Ungleiche Liebe-a Sixteenth-Century Topos. The Modern Language Review 62:661-71.

Coupe, W. A. and Krailsheimer, A. J., eds. 1971. The Continental Renaissance. Baltimore.

\section{D}

Dalby, David. 1965. Lexicon of the Medieval German Hunt. A Lexicon of the Middle High German Terms (1050-1500) Associated with the Chase, Hunting with Bows, Falconry, Trapping and Fowling. Berlin.

Davis, Natalie Zemon. 1975. "Women on Top." In Society and Culture in Early Modern France. Eight Essays, pp. 124-51. Stanford.

Delaborde, Henri. 1888. Marc-Antoine Raimondi. Paris.

Dempster, Germaine. 1941. Sources and Analogues of Chaucer's Canterbury Tales. Edited by W. F. Bryan and Germaine Dempster. Chicago.

Diedrichs, Eugen, ed. 1908. Deutsches Leben der Vergangenheit in Bildern. Introduction by H. Kunzie. 2 vols. Jena.

Duckworth, George E., ed. 1966. The Complete Roman Drama. All the Extant Comedies of Plautus and Terence, and the Tragedies of Seneca in a Variety of Translations. 2 vols. New York.

Dürer through other Eyes. His Graphic Work Mirrored in Copies and Forgeries of Three Centuries. 1975. Exhibition catalogue, Sterling and Francine Clark Art Institute, Williamstown, Mass.

Duyse, Florimond van. 1903-8. Het Oude Nederlandsche Lied. Wereldlijke en Geestelijke Liederen mit vroegeren Tijd. 4 vols. The Hague.

\section{E}

Eigenberger, Robert. 1927. Die Gemãldegalerie der Akademie der bildenden Künste in Wien. 2 vols. Vienna and Leipzig.

Eisler, Colin T. [1975]. Drawings of the German Masters. German Drawings from the 16th Century to the Expressionists. Boston and Toronto.

Erasmi Roterodami Encomium moriac, i.e. Stultitiac laus, Praise of Folly published Basle in 1515 and decorated with the Marginal Drawings of Hans Holbein the Younger, 1931. Translated by Helen H. Tanzer, with an introduction by Heinrich Alfred Schmid. 2 vols, Basel.

Erasmus of Rotterdam. 1971 edition. Praise of Folly and Letter to Martin Dorp 1515. Translated by Betty Radice, with an introduction and notes by A. H. T. Levi. Baltimore.

\section{$\mathbf{F}$}

Falke, Otto von, ed. 1930. Die Sammlung Dr. Albert Figdor Wien. 5 vols. Vienna and Berlin.

1930a. Die Sammlung C. Castiglioni Wien. Gemälde. Skulpturen, Keramik.

Textilen. Berlin. 
Fallersleben, Hoffmann von, ed. 1838. Altniederlandische schaubühne. Abele spelen ende sotternien. Horace Belgicae, vol. 6. Breslau.

Favis, Roberta Smith. 1974. The Garden of Love in Fifteenth Century Netherlandish and German Engravings: Some Studies in Secular Iconography in the Late Middle Ages and Early Renaissance. Unpublished doctoral dissertation. University of Pennsylvania.

Fielding, William J. 1942. Strange Customs of Courtship and Marriage. Philadelphia.

Fischer, Hanns, ed. and trans. 1967. Schwankerzahlungen des deutschen Mittelalters. Munich.

Flechsig, Eduard. 1900. Die Tafelbilder Lucas Cranachs d. A. und seiner Werkstatt. Leipzig.

Friedländer, Max J. 1924-37. Die Altniederländische Malerei. 14 vols. Berlin.

- 1947. Quentin Massys as a Painter of Genre Pictures. Burlington Magazine 89: 114-19.

- 1967-76. Early Netherlandish Painting, comments and notes Nicóle VeroneeVerhaegen, translated by Heinz Norden. 14 vols. in 16. Leiden.

- - and Rosenberg, Jakob, eds. 1932. Die Gemälde von Lucas Cranach. Berlin.

Fuchs, Eduard. 1906. Die Frau in der Karikatur. Munich.

- 1909-10. Illustrierte Sittengeschichte vom Mittelalter bis zur Gegenwart. 3 vols. in 6. Munich.

- 1912-28. Geschichte der erotischen Kunst. 3 vols. Munich.

\section{G}

Geisberg, Max. 1905. Verzeichnis der Kupferstiche Israhels van Meckenemt 1503. Studien zur deutschen Kunstgeschichte, vol. 58. Strasbourg.

—, ed. 1924. Die Kupferstiche des Meisters E. S. 2 vols. Berlin.

- - 1924-30. Der deutsche Einblatt-holzschnitt in der ersten Halfte des $16 \mathrm{Jahr}$ hunderts. 40 vols. in 43. Munich.

-. 1974. The German Single-Leaf Woodcut 1500 to 1550. Walter L. Strauss, ed. 4 vols. New York.

Gembarzewski, Bronislaw. 1926. Muzeum Narodowe w Krakowie. Cracow.

Gerson, Horst. 1950. Van Geertgen tot Frans Hals. Amsterdam.

Gilbert, Creighton. 1967. When Did a Man in the Renaissance Grow Old? Studies in the Renaissance 14:7-32.

Gobel, Heinrich. 1923-34. Wandteppiche. 3 vols. in 6. Leipzig.

Goedeke, Karl, ed. 1856. Pamphilus Gengenbach. Hanover.

- ed. 1872. Das Narrenschiff von Sebastian Brant. Leipzig.

Goetze, Edmund. 1893. Sämtliche Fabeln und Schwanke von Hans Sachs. Neudrucke deutschen Litteraturwerke des XVI. und XVII. Jahrhunderts. No. 116-17. Halle.

Gombrich, Ernst H. 1976. "The Grotesque Heads," In The Heritage of Apelles. Studies in the Art of the Renaissance. pp. 57-75. Ithaca.

Göthe, Georg. 1887. Nationalmusei Tafvelsamling Beskrifvande Förteckning. Stockholm.

Grässe, Johann Georg, ed. 1924. Gesta Romanorum. Das älteste Märchen und Legenden: buch des christlichen Mittelalters. Leipzig.

Grimm, Jacob and Grimm, Wilhelm. 1854-1971. Deutsches Wörterbuch. 17 vols. Leipzig.

Grote, Ludwig, et al. Die Meister um Albrecht Dürer. Exhibition catalogue, Germanisches Nationalmuseum. Nuremberg.

\section{$\mathbf{H}$}

Haight, Anne Lyon, ed. 1965. Hroswitha of Gandersheim. Her Life, Times, and Works, and a Comprehensive Bibliography. New York. 
Harbison, Craig. 1969. Symbols in Transformation. Iconographic Themes at the Time of the Reformation. Exhibition catalogue, Princeton University Art Museum. Princeton, N. J.

Hazlitt, W. Carew, ed. n.d. Shakespeare Jest-Books. 3 vols. New York.

Herlihy, David. 1975. "Life Expectancies for Women in Medieval Society." In The Role of Woman in the Middle Ages, pp. 1-22. Edited by Rosmarie Thee Morewedge. Albany.

Hevesy, André de. 1925. Jacopo de Barbari: Le Maître au caducée. Paris and Brussels.

Hind, Arthur M. 1938-48. Early Italian Engraving. A Critical Catalogue with Complete Reproduction of all Prints Described. 7 vols.

Hoffmann-Krayer, Eduard and Bächtold-Stäubli, Hanns, eds. 1927-42. Handwörterbuch des deutschen Aberglaubens. 10 vols. Berlin and Leipzig.

Hollstein, F. W. H. 1949-74. Dutch and Flemish Etchings Engravings and Woodcuts ca. 1450-1700. 19 vols. Amsterdam.

- 195ff. German Engravings Etchings and Woodcuts ca. 1400-1700. 12 vols. Amsterdam.

Holthausen, F. 1910-11. Die Quellen von Chaucers "Merchant's Tale." Englische Studien 43:170-76.

Hugelshofer, Walter. 1933. Zu Hans Baldung. Pantheon 11:169-77.

Huizinga, Johan. 1954. The Waning of the Middle Ages. Garden City, N: Y.

Hutchison, Jane Campbell. 1966. The Housebook Master and the Folly of the Wise Man. The Art Bulletin 48:73-78.

- 1972. The Master of the Housebook. New York.

Hutter, Herbert. 1972. Lucas Cranach der Ältere in der Akademie der Bildenden Künste in Wien. Vienna.

\section{J}

Jackson, W. T. H. 1968. "Faith Unfaithful -the German Reaction to Courtly Love." In The Meaning of Courtly Love, pp. 55-76. Edited by F. X. Newman. Albany.

Janson, Horst W. 1952. Apes and Ape Lore in the Middle Ages and the Renaissance. London.

John G. Johnson Collection Catalogue of Italian Paintings. 1966. Introduction by Barbara Sweeny. Philadelphia Museum, Philadelphia.

Jongh, E. de. 1968-9. Erotica in vogelperspectief. De dubbelzinnigheid van een reeks 17de eeuwse genrevoorstellingen. Simiolus 3:22-74.

\section{$\mathbf{K}$}

Kahr, Madlyn. 1972. Delilah. The Art Bulletin.54:282-99.

Kalff, Gerrit. [1889]. Geschiedenis der nederlandsche letterkunde in de 16de eeuw. 2 vols. Amsterdam.

Katalog der Gemalde-Galerie im Hause Rudolfinum zu Prag. 1912. Prague.

Katalog der Gemäldesammlung des Germanischen Nationalmuseum in Nürnberg. 1909. 4th ed. Nuremberg.

Kautzsch, Rudolf. 1903. Die Holzschnitte zum Ritter vom Turn. Studien zur deutschen Kunstgeschichte, vol. 44. Strasbourg.

Keller, Adelbert von, ed. 1853. Fastnachtspiele aus dem fünfzehnten Jahrhundert. Bibliothek des litterarischen Vereins in Stuttgart, vols. 28-29. Stuttgart.

- 1855. Erzahlungen aus altdeutschen Handschriften. Bibliothek des litterarischen Vereins in Stuttgart, vol. 35. Stuttgart.

- 1858. Fastnachtspiele aus dem fünfzehnten Jahrhundert. Nachlese. Bibliothek des litterarischen Vereins in Stuttgart, vol. 46. Stuttgart.

Kemp-Welch, Alice. 1913. Of Six Medieval Women. London. 
Klibansky, Raymond, Panofsky, Erwin, and Saxl, Fritz. 1964. Saturn and Melancholy. Studies in the History of Natural Philosophy Religion and Art. London.

Koegler, Hans. 1947. Urs Graf. Basel.

Koepplin, Dieter and Falk, Tilman. 1974-76. Lukas Cranach. Gemälde Zeichnungen Druckgraphik. Exhibition catalogue, Kunstmuseum, Basel. 2 vols. Basel and Stuttgart.

Kohlhaussen, Heinrich. 1942. Die Minne in der deutschen Kunst des Mittelalters. Zeitschrift des deutschen Vereins für Kunstwissenschaft 9:145-72.

Komroff, Manuel, ed. 1928. Tales of the Monks from the Gesta Romanorum. The Library of Living Classics. New York.

Koslow, Susan. 1975. Frans Hals's Fisherboys: Exemplars of Idleness. Art Bulletin 57 418-32.

Kratz, Henry. 1949. Über den Wortschatz der Erotik im Spätmittelhochdeutschen und Frühhochdeutschen. 2 vols. Unpublished dissertation, Ohio State University.

Krönig, Wolfgang. 1936. Der italiensiche Einfluss in der flamischen Malerei im ersten Drittel des 16. Jahrhunderts. Beiträge zum Beginn der Renaissance und der Malerei der Niederlande. Würzburg.

Kühn, Joachim. 1968. Ehen zur linken Hand in der Europäischen Geschichte. Stuttgart.

Kunzle, David. 1973-. The Early Comic Strip. Narrative Strips and Picture Stories in the European Broadsheet from c. 1450 to 1825. Vol. 1. Berkeley, Los Angeles and London.

Kurth, Betty. 1926. Die deutsche Bildteppiche des Mittelalters. 3 vols. Vienna.

Kurth, Willi, ed. 1963. The Complete Woodcuts of Albrecht Dürer, With an introduction by Campbell Dodgson. New York.

\section{$\mathbf{L}$}

Landolt, Hanspeter. 1972. 100 Master Drawings of the 15th and 16th Centuries from the Basle Print Room. Basel.

Larsen, Erik. 1950. Un Quentin Metsys Inconnu à New York. Revue Belge d'archéologie et d'histoire de l'art 19:170-74.

Lauts, Jan. 1959. Hans Baldung Grien. Exhibition catalogue, Staatliche Kunsthalle. Karlsruhe.

Lavalleye, Jacques. [1967] Pieter Bruegel the Elder and Lucas van Leyden. The Complete Engravings, Etchings, and Woodcuts. New York.

Lebeer, Louis. 1939-40. De Blauwe Huyck. Gentsche Bijdragen tot de Kunstgeschiedenis 6:161-229.

Leendertz, Pieter. [1907] Middelnederlandsche dramatische poëzie. Bibliotheek van Middelnederlandsche Letterkunde. Leyden.

Lehrs, Max. [1894] The Master of the Amsterdam Cabinet. New York, Paris, London, and Berlin.

Lehrs, Max. 1908-34. Geschichte und kritischer Katalog des deutschen, niederländischen und französischen Kupferstichs im XV. Jahrhundert. 9 vols. Vienna.

- 1969. Late Gothic Engravings of Germany and the Netherlands. With an essay and notes by Hyatt Mayor. New York.

Lipperheide, Franz. 1907. Sprichwörterbuch Sammlung. Berlin.

Lorris, Guillaume de and Meun, Jean de. 1962 edition. The Romance of the Rose. Translated by Harry W. Robbins. Edited and with an introduction by Charles W. Dunn. New York.

Lutze, Eberhard and Wiegand, Eberhard. 1937. Kataloge des Germanischen Nationalmuseums zu Nürnberg. Die Gemälde des 13. bis 16. Jahrhunderts. 2 vols. Leipzig. 
Maeterlinck, Louis. 1901. Le Genre satirique dans la peinture flamande. Mémoires couronnés par l'academie royale de Belgique, vol. 62. Brussels.

Major, Emil and Gradmann, Erwin. [1942] Vrs Graf. Basel.

Mandach, C. von and Koegler, H. [1942] Niklaus Manuel Deutsch. Sein Leben und sein Wirken. Basel.

Marle, Raimond van. 1931-32. Iconographie de l'art profane au Moyen-Age et à la Renaissance et la décoration des demeures. 2 vols. New York.

Marlier, George. 1954. Erasme et la peinture flamande de son temps. With a preface by Luis Reis-Santos. Brussels.

Martindale, Andrew. 1967. Gothic Art. London.

Mason, Eugene. 1924. French Medieval Romances from the Lays of Marie de France. London, Toronto and New York.

Meiss, Millard. 1974. French Painting in the Time of Jean de Berry. The Limbourgs and their Contemporaries. New York.

Middeleeuwse kunst der noordelijke nederlanden. 1958. Exhibition catalogue, Rijksmuseum, Amsterdam.

Möller, Emil. 1928. Salai und Leonardo da Vinci. Jahrbuch der kunsthistorischen Sammlungen in Wien N. F. 2:139-61.

Murner, Thomas. 1926 edition. Narrenbeschwörung. Edited by M. Spanier. 2 vols. Berlin and Leipzig.

Musper, H. Th., ed. 1970. Der Antichrist und die fünfzehn Zeichen FaksimileAusgabe des einzigen erhaltenen chiroxylographischen Blockbuches. 2 vols., Munich.

Muther, Richard. 1972. German Book Illustration of the Gothic Period and the Early Renaissance (1460-1530). Translated by Ralph R. Shaw. Metuchen, N. J.

\section{$\mathbf{N}$}

Nijhoff, Wouter. 1933-36. Nederlandsche Houtsneden 1500-1550. 2 vols. The Hague.

o

Oettinger, Karl and Knappe, Karl-Adolphe. 1963. Hans Baldung Grien und Albrecht Dürer in Nürnberg. Nuremberg.

Osten, Gert von der. 1973. Deutsche und niederländische Kunst der Reformationszeit. Cologne.

— , and Vey, Horst. 1969. Painting and Sculpture in Germany and the Netherlands, 1500 to 1600 . Baltimore.

Otto, Gertrud. 1964. Bernhard Strigel. Munich.

Owst, Gerald Robert. 1933. Literature and Pulpit in Medieval England. A Neglected Chapter in the History of English Letters and of the English People. Cambridge.

$\mathbf{P}$

Panofsky, Erwin. 1971. Early Netherlandish Painting, Its Origins and Character. 2 vols. New York.

- 1971a. The Life and Art of Albrecht Dürer. Princeton.

Paris, Gaston and Gevaert, Auguste, eds. 1965. Chansons du XV siècle. Paris.

Parker, K. T. 1925. The Engravings of Hans Baldung Grien. Print Collector's Quarterly 12:419-34.

—, and Hugelshofer, W. 1925. Bernardin Strigel als Zeichner. Belvedere 8:29-44.

Parshall, Peter. 1974. Lucas van Leyden and the Rise of Pictorial Narrative, unpublished dissertation, University of Chicago. 
Pedretti, Carlo, ed. 1957. Leonardo da Vinci Fragments at Windsor Castle from the Codex Atlanticus. n. p.

- - 1964. Leonardo da Vinci on Painting. A Lost Book (Libro A). Foreword by Sir Kenneth Clark. Berkeley and Los Angeles.

Pigler, Ander, ed. 1968. Katalog der Galerie alter Meister, Museum der bildenden Künste. Revised ed. 2 vols. Tübingen.

Pigler, Anton. 1974. Barookthemen. Eine Auswahl von Verzeichnissen zur Ikonographie des. 17. und 18. Jahrhunderts. 2d ed. 3 vols. Budapest.

Popham, A. E. 1935. The Engravings of Frans Crabbe van Espleghem. Print Collector's Quarterly 22:92-115.

- 1935a. Catalogue of Engravings and Etchings of Frans Crabbe. Print Collector's Quarterly 22:194211.

- 1945. The Drawings of Leonardo. New York.

$\mathbf{R}$

Randall, Lilian M. C. 1957. Exempla as a Source of Gothic Marginal Illustration. The Art Bulletin 39:97-107.

- 1966. Images in the Margins of Gothic Manuscripts. Berkeley and Los Angeles.

Reinhardstoettner, Karl von. 1886. Plautus. Spätere Bearbeitungen plautinischer Lustspiele. Ein Beitrag zur vergleichenden Litteraturgeschichte. Die klassischen Schriftsteller des Altertums ihrem Einflusse auf die späteren Litteraturen, vol. 1. Leipzig.

Rettick, Edeltraud. 1967. "Bernhard Strigels Handzeichnungen." In Kunstgeschichtliche Studien für Kurt Bauch zum 70. Geburtstag von seinen Schülern, pp. 10114. N.p.

Robertson, Durant Waite. 1973. A Preface to Chaucer. Studies in Medieval Perspectives. Princeton.

Röhrich, Lutz. 1973. Lexikon der sprichwörtlichen Redensarten. 2 vols. Freiburg, Basel and Vienna.

Rörig, Fritz. 1967. The Medieval Town. Berkeley and Los Angeles.

Rosenberg, Jacob, ed. 1923. Martin Schongauer Handzeichnungen. Munich.

Röttinger, Heinrich. 1925. Erhard Schon und Niklas Stör, der Pseudo Schön. Studien zur deutschen Kunstgeschichte, vol. 229. Strasbourg.

Ruhmer, Eberhard. 1963. Cranach. Translated by Joan Spencer. Greenwich, Conn., and London.

- 1965. Albrecht Altdorfer. Munich. Munich.

Rupprich, Hans, ed. 1956-69. Dürer Schriftlicher Nachlass. 3 vols. Berlin.

\section{$\mathbf{S}$}

Sachs, Hannelore. 1971. The Renaissance Woman. Translated by Marianne Herzfeld, revised by D. Talbot Rice. New York.

Saxl, Fritz. 1942. A Spiritual Encyclopedia of the Later Middle Ages. Journal of the Warburg and Courtauld Institutes 5:82-134.

Schabacker, Peter H. 1972. De matrimonio ad morganaticam contracto: Jan van Eyck's “Arnolfini" Portrait Reconsidered. Art Quarterly 35:375-98.

Scheidig, Walter. 1955. Die Holzschnitte des Petrarca-Meisters zu Petrarcas Werk Von der Artzney bayder Glück des guten und widerwärtigen Augsburg 1532. Berlin.

Schlosser, Julius. 1893. Die Bilderhandschriften Königs Wenzel I. Jahrbuch der Kunsthistorischen Sammlungen des allerhöchsten Kaiserhausses 14:214-317.

Schmidt, Hugo, ed. 1930. Bilder-Katalog zu Max Geisberg Der deutsche EinblattHolzschnitt in der ersten Hälfte des XVI. Jahrhunderts. Munich.

Schramm, Albert 1920-43. Der Bilderschmuck der Frühdrucke. 23 vols. Leipzig. 
Pedretti, Carlo, ed. 1957. Leonardo da Vinci Fragments at Windsor Castle from the Codex Atlanticus. n. p.

- - 1964. Leonardo da Vinci on Painting. A Lost Book (Libro A). Foreword by Sir Kenneth Clark. Berkeley and Los Angeles.

Pigler, Ander, ed. 1968. Katalog der Galerie alter Meister, Museum der bildenden Künste. Revised ed. 2 vols. Tübingen.

Pigler, Anton. 1974. Barookthemen. Eine Auswahl von Verzeichnissen zur Ikonographie des. 17. und 18. Jahrhunderts. 2d ed. 3 vols. Budapest.

Popham, A. E. 1935. The Engravings of Frans Crabbe van Espleghem. Print Collector's Quarterly 22:92-115.

- 1935a. Catalogue of Engravings and Etchings of Frans Crabbe. Print Collector's Quarterly 22:194211.

- 1945. The Drawings of Leonardo. New York.

$\mathbf{R}$

Randall, Lilian M. C. 1957. Exempla as a Source of Gothic Marginal Illustration. The Art Bulletin 39:97-107.

- 1966. Images in the Margins of Gothic Manuscripts. Berkeley and Los Angeles.

Reinhardstoettner, Karl von. 1886. Plautus. Spätere Bearbeitungen plautinischer Lustspiele. Ein Beitrag zur vergleichenden Litteraturgeschichte. Die klassischen Schriftsteller des Altertums ihrem Einflusse auf die späteren Litteraturen, vol. 1. Leipzig.

Rettick, Edeltraud. 1967. "Bernhard Strigels Handzeichnungen." In Kunstgeschichtliche Studien für Kurt Bauch zum 70. Geburtstag von seinen Schülern, pp. 10114. N.p.

Robertson, Durant Waite. 1973. A Preface to Chaucer. Studies in Medieval Perspectives. Princeton.

Röhrich, Lutz. 1973. Lexikon der sprichwörtlichen Redensarten. 2 vols. Freiburg, Basel and Vienna.

Rörig, Fritz. 1967. The Medieval Town. Berkeley and Los Angeles.

Rosenberg, Jacob, ed. 1923. Martin Schongauer Handzeichnungen. Munich.

Röttinger, Heinrich. 1925. Erhard Schon und Niklas Stör, der Pseudo Schön. Studien zur deutschen Kunstgeschichte, vol. 229. Strasbourg.

Ruhmer, Eberhard. 1963. Cranach. Translated by Joan Spencer. Greenwich, Conn., and London.

- 1965. Albrecht Altdorfer. Munich. Munich.

Rupprich, Hans, ed. 1956-69. Dürer Schriftlicher Nachlass. 3 vols. Berlin.

\section{$\mathbf{S}$}

Sachs, Hannelore. 1971. The Renaissance Woman. Translated by Marianne Herzfeld, revised by D. Talbot Rice. New York.

Saxl, Fritz. 1942. A Spiritual Encyclopedia of the Later Middle Ages. Journal of the Warburg and Courtauld Institutes 5:82-134.

Schabacker, Peter H. 1972. De matrimonio ad morganaticam contracto: Jan van Eyck's “Arnolfini" Portrait Reconsidered. Art Quarterly 35:375-98.

Scheidig, Walter. 1955. Die Holzschnitte des Petrarca-Meisters zu Petrarcas Werk Von der Artzney bayder Glück des guten und widerwärtigen Augsburg 1532. Berlin.

Schlosser, Julius. 1893. Die Bilderhandschriften Königs Wenzel I. Jahrbuch der Kunsthistorischen Sammlungen des allerhöchsten Kaiserhausses 14:214-317.

Schmidt, Hugo, ed. 1930. Bilder-Katalog zu Max Geisberg Der deutsche EinblattHolzschnitt in der ersten Hälfte des XVI. Jahrhunderts. Munich.

Schramm, Albert 1920-43. Der Bilderschmuck der Frühdrucke. 23 vols. Leipzig. 
Urzidil, Johannes. 1942. Hollar. A Czech Emigré in England. London.

Valentiner, W. R. and Suida, William E. 1949. Leonardo da Vinci. Loan Exhibition. Exhibition catalogue, Los Angeles County Museum. Los Angeles.

Veit, Ludwig. [1969]. Das liebe Geld. Zwei Jahrtausende Geld- und Münzgeschichte. Bibliothek des Germanischen National-Museums zur Kulturgeschichte, Nuremberg, vol. 30. Munich.

\section{$\mathbf{W}$}

Waetzoldt, William. n. d. Dürer and his Times. Translated by R. H. Boothroyd. New York.

Walker Art Gallery, Foreign Schools Catalogue. 1963. 2 vols. Liverpool.

Warburg, Anni. 1930. Israhel van Meckenem. Sein Leben, sein Werk und seine Bedeutung für die Kunst des ausgehenden 15. Jahrhunderts. Edited by Eugen Lüthgen. Bonn.

Wardroper, John. 1970. Jest Upon Jest. A Selection from the Jestbooks and Collections of Merry Tales Published from the Reign of Richard III to George III. London.

Wescher, Paul. 1938. Ein "ungleiches Liebespaar" von Hans von Kulmbach. Pantheon 22:376-79.

White, Lynda. 1976. The Unequal Couple in Northern Reformation Art, unpublished paper, University of Virginia.

Wiegand, Sister M. Gonsalva. 1936, ed. and trans. The Nondramatic Works of Hrosvitha: Text, Translation and Commentary. Published dissertation, St. Louis University. St. Louis.

Wilk, Sarah. 1973. Tullio Lombardo's "Double-Portrait” Reliefs. Marsyas 16:67-86.

Willeford, William. 1969. The Fool and His Scepter. A Study in Clowns and Jesters and their Audience. N.p. .

Wind, Barry. 1972. Studies in Genre Painting: 1580-1630. Unpublished dissertation, Institute of Fine Arts, New York University. New York.

Winkler, Friedrich. 1951. Dürer und die Illustrationen zum Narrenschiff. Deutscher Verein für Kunstwissenschaft, vol. 36. Berlin.

Winzinger, Franz. 1975. Albrecht Altdorfer. Die Gemälde. Munich and Zurich.

Woermann, Karl. 1899. Katalog der Königlichen Gemäldegalerie zu Dresden. 4th enlarged ed. Dresden.

Wolffhardt, Elisabeth. 1954. Beiträge zur Planzensymbolik. Zeitschrift für Kunstwissenschaft 8:177-96.

Wulff, August. 1914. Die Frauenfeindlichen Dichtungen in den romanischen Literaturen des Mittelalters bis zum Ende des XIII. Jahrhunderts. Romanischen Arbeiten, vol. 4. Halle.

Würtenberger, Franzsepp. 1957. Pieter Bruegel d. A. und die deutsche Kunst. Wiesbaden, . 


\section{INDEX}

\section{SUBJECTS}

A

Adultery, 15, 17, 19-22, 27, 45; and the young, 30; and wife, 54, 75; gesture relating to, 60

Animal. See Bird; Dog; Fox; Goat; Horse; Monkey; Pig; Stag

Antichrist, 98, $162 \mathrm{HL}$ nos. 56 and 57

Anticlericalism, 37, 38

Apple, 23

Aristocracy, 16, 37, 102. See also Nobility

Aristotle and Phyllis, 34, 48, 102, 113, 120

Art, satire in, 34, 35, 39, 41, 42, 45, $55,90,106-8,116,121,123$

Ass (Donkey), 47, 59; ears of, 67. See also Fool, cap of

Attributes, of fool, 52, 65

Audience, comprised of humanists, 120; for paintings, 116-118, 120;

for prints, 45, 118-21; for Unequal Lovers, 12, 98, 118-20; literary, 34; lower- and middle-class, 16,119 ; theatrical, 13 ; upper-class, 14,16

\section{B}

Bathmaid, 36

Bathhouse, 39, 41

Battle of sexes, folly of, $128 \mathrm{n} .106$

Beauty, 17, 18, 20, 28, 68; of young man, 22; of young woman, 18, 20, 28, 68; power of, over tyrants, 69

Bed, 39, 94

Beggar, 53

Bell, 52, 55, 59

Bellows, 65-67

Betrothal, 90, 93
Bird, 37, 39, 54, 81, 100. See also Chicken; Cock; Cuckoo; Duck; Goose; Hawk; Hen; Sparrow; Waterbird

Blindness, 50; of old man, 20, 23, 25; of old woman, 27

Bourgeoisie. See Middle class

Bowl, 51, 52

Bread, 51-53, 81

Breast, 45, 62, 98; fondled, 42, 65, 109 ; offer of, 41

\section{C}

Capitalism, 101, 116

Cards, playing, 68, 70, 98, 138

Carnation, 93

Carnival, 133 n. 203

Carnival play, 23-25, 27, 31, 34, 54, 56,108

Charms, of woman, 49

Chastity, 14, 20, 22

Chastity belt, 25, 74-77, 79

Cheese, 81

Chiaroscuro drawing, 87 fig. 59, 90 fig. 62,91 fig. $63,98,108,120,164$

Chicken, 50, 50 fig. 23

Chivalry, 14

Claw, 39

Clergy, 16, 35, 37

Clothing, 94, 101, 109, 143; of fool, 52,55 ; of prostitute, 86 ; social class as reflected in, 82-89, 97

Cock, 73

Coins, 65, 75, 79, 81, 121. See also Money

Comedy, 13, 51, 57, 59, 120

Commandment, seventh, 42, 43 fig. 16 , 45; ninth, 44, 45; Ten, $43-45$

Costume. See Clothing 
Courtly love, 101-102

Crown, 90-94

Cuckold, old man as, 19, 20, 30, 71, 72

71-72 figs. 43-45, 100

Cuckoo, 47, 54

Culprit, 123

Cunning, 18, 24, 77, 79; of young woman, 19, 41

Cushion cover, 117 fig. 78, 174

HL 86

\section{D}

Dame Venus, 46-50, 55, 56

David and Bathsheba, 48

Death, 98, 100, 108, 110

Deceit, 22, 31, 47, 49, 113; of woman, 104, 113; of young man to old woman, 30; of young woman, 18, 42, 73, 104, 113

Deception, $61,70,71$; self-, of old man, 15, 18, 19

Demon, 42, 44, 45, 66, 67, 93, 138

Didacticism, 42, 45, 98, 100

Distaff raised (gesture), 128 n. 106

Divorce, 31

Doctor, 30

Dog, 37, 38 figs. 10-11, 39, 56 fig. 30; lap, 42, 57, 57 fig. 31

Donkey, 47, 59, 67

Dowry, 17, 27, 28, 62, 102

Drama, 14, 18, 34, 69

Dress. See Clothing

Drink, offer of (gesture), 45

Duck, 53, 54

\section{$\mathbf{E}$}

Eating, 51-52

Eggs, 53, 54

Eroticism, 109, 110, 113, 117; of gestures, 42, 110, 135 n. 251

Evil, 98

\section{$\mathbf{F}$}

Faithfulness, 22, 39, 77

Falcon, 42

Farce, 18, 31

Fastnachtspiel. See Carnival play

Feminine characteristics. See Old

woman; Woman; Young woman
Fertility, 54

Fiddling, 24, 25 fig. 2

Fire, 48, 65-67, 121

Flattery, 31, 49, 60

Flower. See Carnation; Garland; Rose

Folk literature, 11

Folly, 15, 22; and battle of sexes, 128 n. 106; and lasciviousness, 56; and love, 15, 48-49, 116; and youth, 15; associated with men, 55, 77, 79, 113; in Narrenschiff, 59, 107; in Praise of Folly, 61-65, 69

Follies of Love. See Love, Folly of

Fool, 55-82, 106-8; attributes of, 52, 65 ; cap of, $28,48,75,79,94$; cap of, worn by old man, $31,50,55$, 57; cap of, worn by young man, 59; commanded by Dame Venus, 47-49; costume of, 52, 55; description of, 55; in Master E.S., 101, 128 n. 106, 135 n. 251; lasciviousness of, 39, 67,135 n. 251 ; mocks old man, 117 , 141; monk dressed as, 39; old man as, 30, 31, 41-42; staff (bauble) of, $55,56,60$; tree with many a, 78 fig. 51, 79; woman makes man into, 102; young man as, 59 fig. 32,59

Foolishness, 41, 52, 65, 81, 128 n. 106; and lovers of all ages, 61 ; and woman, 39; of old lovers, 34, 48-50, 69; of old men, 18, 19, 24, 27, 30, 34, 42, $50,57,61,75,79,106,107$; of young men, 24, 27, 44 fig. 17

Fortuna, 93, 93 fig. 65

Fox, 39

Freedom, 77, 97

Fruit, 19, 20, 23, 138

Fruit tree, 19, 20, 23, 25, 34

\section{G}

Game, 68

Garden, enclosed, 106; love, 47, 49, 101

Garland, 90-94

Genitals, 56; Female 39, 57, 110, 135 n. 251; importance of size of male's and female's, 31 ; male's 39 , 110,128 n. 110. See also Penis; Testicles

Genre, 53, 100, 106 
Gesture, 39, 42; distaff, raising of, 128 n. 106; drink, offer of, 45 ; erotic, $42,110,135$ n. 251 ; hand, raising of, 35; hand, placement under arm, 57; nose tickled with reed, 60 ; relating to adultery, 60 ; skirt, raising of, 87

Glasses, eye, 60-61

Goat, 73

God, 23, 25, 34, 48, 49

Goose, 81

Gown flap, 110, 135 n. 251

Greed, 22, 55

\section{H}

Hair, garlands used to decorate, 90-94; length of, 35, 42, 52, 94-97, 99

fig. 68; of prostitutes, 97

Hand (gestures), 35, 57

Harlot, 89; in literature, 12, 20. See also Prostitute; Whore

Hat, 94, 97

Hawk, 14-15

Headdresses, 39, 42

Heat, 65

Hen, 50

Henpecked husband, 113, 128 n. 106

Hook, 49

Horns, 73, 81

Horse, 24

Human nature, 11

Humanists, 26, 98, 126 n. 65, 108; audience comprised of, 120

Humor, 19, 34, 59, 65, 68, 98

Hunt, 39, 42

Husband, 17, 54, 77, 102; controlled by wife, $22,47,113$; old, with young wife, 30,31

\section{I}

Idiot, 49

Idleness, 65

Incest, 21, 98

Infidelity. See Adultery

J

Jest, 23

Jester, 55. See also Fool

Judah and Tamar, 20

Judge, 18

Judith and Holofernes, 75

Jug, 51, 52

\section{$\mathbf{K}$}

Key, 75, 77

Knight, 14, 18

Kunstkammer, 155

$\mathbf{L}$

Land, 101, 114

Lap, 42, 54

Lasciviousness, 39, 50, 52, 56-57; and behavior of woman, 113, 135

n. 251; and folly, 56; artistic interest in, 45, 98, 100; of fool, 39, 67, 135

n. 251

Latin, 98

Laurel (bay), 94

Lay, 14

Life expectancy, 102, 105

Literature, audience of, 34; old wife in, 16-18, 27, 30, 31, 48; prostitute in, 13, 20; satire in, 16, $18,19,27,59.65,68$; young wife in, $14,17,19,20,22,28,30,31$, 69

Lock, 75, 77

Love, 24, 31, 48-50, 101-102, 113; allegory of, 39; as enslaver of men, 102; characteristics of, 13; controlled by woman, 101; courtly, 101-2; folly and, 15, 48-49, 116; as game between the sexes, 68; glorified, 15; illicit, 39 94, 97, 102, 106. See also Sex; Main consideration of relationship, 15, 22; presiding over affair, 16; purchased. See Mercenary love; triumphs, 19;

Love garden, 47, 49, 101

Love triangle, $12,15,19,24,33,34,59$, $71,75,87,97,138,173-79$ HL85100

Lovers, 61

Lower class, 20

Lower- and middle-class, audience, 16 , 119

Lust, 17, 49-50, 57, 65, 81, 121; fires of, $65-67,121$; of old man, 13, 16, $39,50-55$; of old woman, 67; of woman, $75,77,101$; of young man, 15; of young woman, 19, 24, 30,31 ; sin of, called unchastity, 27 , $42,45,97$

Lute, 98

Luxury, 36, 42, 57, 94 
Madness, 13

Makeup, 62, 69

Man, 79, 113; power over woman, 123

Manuscripts, 14, 17, 23, 26, 34-36, 97, 104

Marcolf and Polikana, 51, 51 figs. 24, 25

Marriage, 16, 17, 24, 49, 97, 102-4;

age at, 22; between classes

(morganatic), 86, 103-4; fidelity

in, 21-22; folly of, 65 ; gesture

associated with, 87; of old man and young woman, 14, 19-20, 23, $24,30,31,69,97,114$; to old woman, 16, 27, 59, 63; parents blamed for unequal marriage, 14, 19, 24; symbol of, 90, 92-93

Maumariée ("of Those Badly Married"), 24

Memento Mori, 98, 100, 108

Men, enslaved by love, 102; genitals of, exposed, 39, 110, 128 n. 110

Mendicant preachers, 16, 36

Mercenary love (venal love), 15-18, $28,49,75,89,101,123$; marriage as, 18, 27, 30, 31, 93. See also Prostitute

Middle class, 101-4, 119, 120

Midwife, 31

Mirror, 52, 106

Misogyny, 34

Monasteries, 26

Money, 15, 37; and folly, 27, 55; and Unequal Lovers audience, 120; as basis of love, 15-17; deceit rewarded with, 22; of man lost to woman, 47; of old man, 28, 31, 42, 71, 75; of old woman, 59, 62, 63, 77; power of, 87,116 ; relation of, to vanitas, 108; social importance of, 101, 105; women hungry for, 114. See also Coins; Wealth

Money bag, 28, 35, 59, 102 ill. See also Purse

Monk, 39

Monkey, 47, 89, 106

Moralizing, 17, 19, 27, 34, 45, 59, 98, $100,106,108$

Mush, 51-52
Nest, 54

Nobility, 14, 16, 103-4, 120; lower, 103-4. See also Aristocracy

Nose, tickled with reed (gesture), 60

$\mathbf{0}$

Obscenity, 23, 24, 31, 34

Oil on board, 92 fig. 64, 149 HL27

Old age, and folly, 15, 106; Rennaissance conception of, 134 n. 232; sexuality of, $28,50,65-67$

Old doctor, 30

Old man, absurdity of, 13; affectionate nature of, 20; as cuckold, 19, 20, $30,71,71-72$ figs. $43-45,100$; as fool, 30, 31, 41-42; blindness of, 20, 23, 25; deceived, 30, 31 (see also Deceit; Deception); foolishness of, $18,19,24,27,30,34,42,50$, 57, 61, 75, 79, 106, 107 (see also Foolishness); impotence of, 14, 18, 19, 23, 28, 30, 31, 108, 110; infirmity of, 106; lust of, 13, 16, 39, 50-55; madness of, 13; married to young woman, $18,20,22,28$, $30,69,103,114$; mocked by fool, 117,141 ; physical description of, $20,23,24,30,68,69$; self-deception of, $15,18,19$; stupidity of, 13 ; unaffectionate nature of, 30 ; wealth of, 19, 23, 24, 65

Old woman, 18, 24, 26-28, 49, 54, 59,65 ; blindness of, 27; deceived by young man, 30; description of, $16,24,27,31,59,123$; lust of, 67 ; marriage to young man, $77,93,104$; sexual power of, 128 n. 106 ; shrewish personality of, $27,59,77$; wealth of, $27,30,31,65$; with young man, 18, 26-8, 30, 31, 103, 113, 144-45 HL14-16

\section{$\mathbf{P}$}

Paintings, audience for, 116-18, 120

Panel with paper, 118 fig. 79, 181 HL104

Pants, battle over (theme), 113, 130 n. 260 
Parents, 14, 19, 24

Passion, 63, 65, 79

Patient, 30

Patron, 116-118, 120. See also Audience

Pear tree, 19, 20

Peasant, 24, 53, 148 HL23-24

Penis, 41, 54, 75, 81, 135 n. 251

Pig, 51

Pleasure, symbols of, 33

Poem, 24, 31; sung (Spruch), 24

Popularity, of Unequal Lovers, 115-17

Population, 102-3, 114

Pornography, 109-13

Power, man's over woman, 123;

of beauty over tyrants, 69; of Women (theme), 34, 39, 47, $75,101-2,106,114,128$ n. 106 (see also Aristotle and Phyllis; Judith and Holofernes; Samson and Delilah; Vergil in the Basket); sexual, of old woman, 128 n. 106; struggle by woman within the home, 18; woman's in real life, 102 ; woman's over man, 41,47 , $49,55,75,79,113$

Pre-Columbian whistle, 11

Prints, audience for, 45, 118-21

Property, 79

Prose tales, 23, 69

Prostitute, 16, 41, 57, 87, 89, 97, 104, 108,113 ; clothing of, 86 ; hair of, 97; in literature, 13. See also Harlot; Whore

Psalter, 35

Publishers, 20, 26, 27, 29, 30, 32, 45

Purse, 24, 28, 68, 70, 71, 75, 106, 113, 123. See also Money bag

Putto, 65, 138

\section{$\mathbf{R}$}

Restraints on young woman. See Chastity belt; Lock

Rose, 57, 57 fig. 31

S

Saint Peter, 23, 25, 34

Samson and Delilah, 22, 48, 102, 113
Satire, 141; in art, 34, 35, 39, 41, 42, $45,55,90,106-8,116,121,123$; in literature, $16,18,19,27,59,65,68$; in art and literature, 12, 101-2

Secularism, 12, 36, 106, 119, 120, 136 n. 265

Seduction, 47,89

Sermon, 16, 17, 36

Sex, 19, 28, 31, 52-54; for procreation, 49. See also Love, illicit

Sex role reversals, 135 n. 247

Sexual incompatibility, 31

Shrew, 27, 59, 77

Sin, 59, 73, 77, 97, 106

Skeleton, 100. See also Death

Skirt, raising of (gesture), 87

Skittles, 28

Society, 101

Social class, clothing as reflection of, 82-7, 97. See also Aristocracy; Lower class; Middle class; Nobility

Song, 24, 30

Sotterniën (satirical endings of dramas), 18

Sparrow, 54

Spoon, 52

Stag, 23

Still life, 100

Susannah and the Elders, 22, 50

Syphilis, 28

$\mathbf{T}$

Tales, humorous (Schwankerzählungen), 24-26, 34, 94

Taste of time, 109-14

Temperament, melancholic, 94, 97

Testicles, 54

Theater, audience for, 13; comedy, 13, $51,57,59,120$; drama, 14, 18, 34, 69

Theft, 106

Titillation, 16, 34, 45, 100, 108

Tower, 14, 15, 44

Transience, 33 figs. 5 and 6. See also Vanitas

Tree, 19, 20, 23, 25, 34; with fools, 78 fig. 51,79

Triangle, love. See Love Triangle 


\section{$\mathbf{U}$}

Unchastity. See Lust

Unequal Lovers, audience for, 12,98 , 118-20

Upper class, audience comprised of, 14,16

\section{V}

Vanitas, 98, 100, 108. See also Transience

Venal love. See Mercenary love

Venus, 52. See also Dame Venus

Vergil in the Basket, 48

Victory, 94

Virtue, 94

\section{W}

Waterbird, 54, 81

Wealth, 18, 49, 63, 83, 102-4, 119; of old man, 19, 23, 24, 65; of old woman, 27, 30, 31, 65, See also Money

Weapons, 42, 110, 135 n. 251

Weight, 51-52

Whore, 15, 16, 22, 25, 34. See also Harlot; Prostitute

Wife, 16, 22, 30, 63, 104; and adultery, 54, 75; controls husband, $22,47,113$; old, in art, 27, 32

fig. 4, 59; old, in literature, 16-18, $27,30,31,48$; young, in art, 36 , $60,87,89$; young, in literature, $14,17,19,20,22,28,30,31,69$; young, in society, 77,94 ; young, with old husband, 30, 31. See also Marriage

Wine, 52, 81

Wing, 67

Wisdom, 24, 39, 48, 49, 69, 106

Woman, and foolishness, 39; as controller of love affairs, 101; as culprit, 123; as headstrong, 77; as property, 79; as shrew, 77; as temptress, 101, 123; charms of, 49; cunning of, 18, 19, 24, 41, 77, 79; genitals of, $39,57,110,135,251$; greed of, 55 ; lascivious behavior of, 113, $135 \mathrm{n}$. 251 ; lust of, $75,77,101$; makes man into fool, 102; mercenary desires of, 123; nature of, 79, 97; power of, in real life, 102; power of, over man, 41, $47,49,55,75,79,113$; power struggle of, within the home, 18; wiles of, $77,79,106$

Women authors, 14-15

\section{Y}

Young man, as fool, 59 fig. 32, 59; foolishness of, 24, 27, 44 fig. 17; beauty of, 22; deceit of, 30; lust of, 15; married to old woman, 77, 93, 104 ; mercenary desires of, 31 ; preferred by young woman, 30; sexual ability of, 24; with old woman, 18 , $26-8,30,31,103,113,144-45$ HLL1416

Young woman, adulterous desire of, for young man, 30 ; beauty of, 18,20 , 28, 68; complains about old husband, 30,31 ; cunning of, 19 , 41; deceit of, 18, 42, 73, 104, 113; extricated from tower, 15 ; fanning fire, 67; flattery of, 31 ; genitals of, exposed, 135 n. 251 ; lust of, 19, $24,30,31$; married to old man, 18 , 20, 22, 28, 30, 69, 103, 114; mercenary intentions of, 16,30 ; physical description of, 30,68 ; preference of, for young man, 30

Youth, 24, 30, 69, 104; folly of, 15; mercenary desires of, 93. See also Young man; Young woman 


\section{NAMES AND LOCATIONS}

\section{A}

Aesop (Steinhöwel), 23

Agricola, Rudolf, 120

Allegory of Adultery (C. Massys), 54, 54 fig. 28

Allegory of Fiddling (Graf), 24, 25

fig. 2, 93

Alsation or Swiss Artist, 117 fig, 78, 174 HL86

Altdorfer, Albrecht, 110

Ameto (Boccaccio), 22

De Amore (Capellanus), 49, 104

Amorous Couple on a Grassy Bench

(Master E.S.), 42

Amsterdam, Goudstikker Art Dealer, 1936, 166 HL65

Amsterdam, Rijksprentenkabinet, Rijksmuseum, 139 HL nos. 1 and 2 Anamorphic Love Triangle (Schön), 72 fig. 44, 176 HL93

Antwerp Songbook, 30

Aristotle and Phyllis (Baldung), 112

fig. 74, 113

Augsburg artist, 44 fig. 18

Austrian artist, 97, 99 fig. 68

\section{B}

Baldung, Hans, 75, 112 fig. 74, 113, 164; engraving, 86 fig. 58,115 , 116 HL9, 145; paintings, 84 fig. 56,148 HL25; 85 fig. 57, 108, 149 HL26

The Ball (Master MZ), 68

Barbari, Jacopo de', 94, 95 fig. 66, 97, 108, 116, 117, 141, 141 HL7; after, 142 HL8
Basel, Kupferstichkabinett, Kunstmuseum, 25 fig. 2; 89 fig. 61, 165 HL63; Holbein's drawing, 63 fig. 36, 65, 167 HL67; Manuel's Love Triangle, 87, 90 fig. 62, 175 HL90; Manuel's Old Man and Young Woman, 86, 87 fig. 59, 143 HL11; Manuel's Old Woman and Young Man, 45, 64 fig. 37, 65-67, 98, 167 HL68

Bathhouse as Brothel (Master of the Banderoles), 39, 41 fig. 13

Bathsheba (Memling), 57

Beham, Hans Sebald, 52, 55 fig. 29, 56, 110, 110 fig. 72

Berlin, Art Dealer, 166 HL66; International Sale 1934, 157 HL47;

Kupferstichkabinett, Staatliche Museen Preussischer Kulturbesitz, 91 fig. 63, 164 HL61; Lepke's Sale 1920, 142 HL8; Staatsbibliothek Preussischer Kulturbesitz, 40 fig. 12

Besancon, 152 HL36

Bloemaert, Cornelis, 50

Boccaccio, Decameron, 18-19, 23, 36; Hroswitha, compared to, 14, 18, 126 n. 65; Marie de France, compared to, 18; Plautus, compared with, 18

Boccaccio, Giovanni, Ameto, 22; la Tour Landry, compared to, 22

Bohemian artist, 36 fig. 8

The Book of the Chevalier de la Tour Landry (la Tour Landry), 20-22

Bracciolini, Poggio, 26

Brant, Sebastian, 120; Narrenschiff, 34, 50, 52, 65, 75, 107; Narrenschiff, "Amours," 47, 48 fig. 21, 88; Narrenschiff, "Unequal Couple," 27, 44, 58 fig. $32,59,60,77,90$ 
Bromyard, John, 16

Bruyn, Nicolas de, 51, 51 fig. 25

Büchlein Der Sele trost ("Book of the Soul's

Consolation"), 44-5, 44 fig. 18

Budapest, Collection Baron Herzog, 150 HL30; Sale Ernst Museum 1921, 154 HL41; Szépmüvészeti Muzeum, 82 fig. 54, 144 HL14; 83 fig. 55, 146 HL17; 147 HL21

Die Buhlschaff auf dem Baume

("Love in the Tree"), 24-26

Burgkmair, Hans, 96 fig. 67, 97

Burgundian artist, 40 fig. 12

Die Buskenblaser ("The Can Blower"), 18

\section{C}

Cage of Fools (Schön), 121, 122 fig. 81

Canterbury Tales (Chaucer), 19-20, $22,23,36$

Capellanus, Andreas, 49, 104

Card-Playing Couple (van Meckenem), 68

Castagnola, Thyssen Collection, 69 fig. 41, 174 HL87

Celtis, Conrad, 26, 126 n. 65

Chaucer, Geoffrey, 19-20, 22, 23, 36 , compared to, 22

Cicero, Marcus Tullius, 26

Coburg, Kunstsammlungen der Veste Coburg, 78 fig. 51

Colloquies (Erasmus), 28-29

Cologne, Sale Lempertz 1964, 155 HL42

Congreve, William, 11

Cornelisz. van Amsterdam, Jacob, 59, 60,60 fig. $33,63,68,116,166$ HL64; after, 166 HL65, 166 HL66

Courtship (Picasso), 11

Crabbe van Esplegem, Frans, (The Crayfish Master), 71, 72 fig. 45, 75, 177 HL95

Cranach the Elder, Lucas, 87, 97, $115-17,120,144-46 ; 145-72 \mathrm{HL}$ nos. $16,17,22,23,28-32,34,36-$ 40, 44-46, 49, 50, 53, 54, 77, 82; Nuremberg Old Man, Young Woman, 80 fig. 53, 81; Old Woman, Young Man, 82 fig. 54, 83, 144 HL14;
Payment, 78, 79 fig. 52, 100, 108, 171 HL78; Ten Commandments, 45, 45 fig. 19; School of, 144; 147-173 HL nos. $21,24,27,30$, $33,43,47,48,51,52,81,83,84$

Cranach the Younger, Lucas, 144, 152-171 HL nos. 35, 41, 42, 75, 80

\section{D}

Dame Venus (Dürer), 47, 48 fig. 21; (Master of the Power of Women), 47, 49 fig. 22; (Rhenish artist), 46 fig. 20;102, 105 fig. 69

Darmstadt, Hessishes Landesmuseum, 148 HL23

Decameron (Boccaccio), 18-19, 23, 36

Deschamp, Eustache, 22

"A Divorce" (Eine Ehescheidung) (Tyrolian), 31

Doesborch, Jan van, 70

Domenichi, Lodovico, 23

Douai, Musée, 147 HL20

Dowdeswell, 161 HL54

Dream of the Toler (Dürer), 65, 66 fig. 38

Dresden, Staatliche Kunstsammlungen, 171 HL80

Dürer, Albrecht, 20, 26, 94, 118-119, 120, 165; Dame Venus, 47, 48 fig. 21; Dream of the Idler (Dürer), 65, 66 Melencolia I, 94; Old Wife and Young Fool, 27, 44, 47, 57, 58 fig. 32, 59, 60, 163 HL58; Old Man and Young Woman, 21 fig. 1, 24, 88, 120, 163 HL59; St. Chrysostomus, 110, 111 fig. 73

Düsseldorf, Kunstmuseum, 151 HL31

\section{$\mathbf{E}$}

Eindoven, late Philips Collection, 175 HL89

Embracing Couple with Demon (Augsburg artist), 44, 44 fig. 18

Embracing Couple with Ape (Nuremburg artist), 106, 107 fig. 70

English artist, 35, 35 fig. 7

Erasmus, Desiderius, 13, 34, 97; Colloquies, 28-29; Praise of Folly, 
13, 28, 31; Praise of Folly, Unequal

Couples, 61-63, 63 fig. 36, 65, 68-70

Erfurt, Städtisches Museum, 147 HL22

Erlinger, Georg, 29

Eunuchus (Terence), 26, 52

Everaert, Cornelis, 31

Exempla, 16-17, 36

\section{F}

Fais et dis de la cité de Romme

(Valerius Maximus), 36

Fantastic Alphabet (Master E.S.),

37-39, 38 figs. 10 and 11

Flemish(?) artist, 170 HL74

Florentine artist, 73, 73 fig. 46

Fortuna(?) (Nuremberg artist), 93, 93 fig. 65

Fountain of Youth (Master of the Banderoles), 109, 109 fig. 71

Franco-Flemish artist, 36, 37 fig. 9; 39 , 40 fig. 12

Frederick the Wise, 145

French artist, 175 HL91

Fröschlein of Reutlingen, Thomas, attributed to, 162 HL56

Furter, Michael, 20

\section{G}

Gengenbach, Pamphilus, 27-28

German artist, 61, 62 fig. 35, 143

HL12, 162 HL57, 181 HL103

Gesta romanorum, 17-18

Gorleston Psalter (English artist), 35, 35 fig. 7

Gouchmatt ("Meadow of Fools") (Gengenbach), 27-28

Graf, Urs, 176; Allegory of Fiddling, 24, 25 fig. 2, 93; Love Triangle, $32-33,33$ fig. 6, 59, 87, 93, 97, 98, 100, 108, 115, 173 HL85

Groningen, Museum van Oudheden, 60 fig. 33, 166 HL64

\section{H}

Halle, Bodenburg Collection, 172 HL83

Harold and Maude, 11

Vom Heiraten Spil ("A Play About Marriage"), 23, 120
Hoefnagel, Jacob, frontispiece, 140 HL5, 141

Holbein the Younger, Hans, 63 fig. 36, 65, 167 HL67

Hollar, Wenzel, 140 HL6, 141

The Horsemarket of Women (Schön), 123, 123 fig. 82, 171 HL79

The Housebook Master, Old Woman and Young Man, 120, 121 fig. 80, 139 HL2; Old Man and Young Woman, 41 fig. $14,51,52,88,90,113,139$ HL1

Hroswitha of Gandersheim, 14; Boccaccio compated to, 18; Plautus compared to, 14, 18, 126 n. 65 ; revival of, 26,34

Hume, David, 11

Imperial Golden Bull (Bohemian artist), 36 fig. 8

Isidore of Seville, 50

I

Imperial Golden Bull (Bohemian artist), 36 fig. 8

Isidore of Seville, 50

\section{J}

Jestbooks (Shakespeare), 30

Julien des Augustins, 23

\section{$\mathbf{K}$}

Karlsruhe, Kunsthalle, 85 fig. 57, 149 HL26

von Keisersperg, Geiler, 120, 143

The King of the Goats (Florentine artist), 73,73 fig. 46

Der kram der narrenkappen ("The Shop of Fools' Caps"), 94

Krodel, Wolfgang, 92 fig. 64, 93, 149 HL27

von Kulmback, Hans, 26, 115, 116, 116 fig. $77,142 \mathrm{HL} 10$

\section{$\mathbf{L}$}

"Lay of Equitan" (Marie de France), 15; "Lay of Laustic" (Marie de France), 17; "Lay of Yonec" (Marie de France), 14,18 
Leonardo da Vinci, frontispiece, 140 HL5, 141, 145, 169, 171; circle of, 170, HL73, 170 HL76

Leu, Hans, 78 fig. 51,79

van Leyden, Lucas, Old Fool Embracing

Young Woman, 67, 67 fig. 39, 68, 144 HL13; Love Triangle, 69 fig. 41, 174 HL87; Prodigal Son(?) in a Tavern, 70 fig. 42, 71, 146, 176; after, Love Triangle etching, 71 fig. 43, 71, 100, 176 HL92; Love Triangle paintings, 100, 115, 174 HL88, 175 HL89; circle of, 113, 114 fig. 75, 181 HL105

Liège, Bibliothèque de l'Université, Wittert Collection, 146 HL19

Liverpool, Walker Art Gallery, 84 fig. 56, 148 HL25

Locher Philomusus, Jakob, 26

London, Arensberg Collection, $170 \mathrm{HL}$ 75; British Library, 35 fig. 7; 33 fig. 6, 173 HL85; Harris 1932, 172 HL 81; Koetser 1951, 173 HL84; Private Collection, 174 HL88

de Lorris, Guillaume, and de Meun, Jean, 15, 49

Lot and his Daughters (Altdorfer), 110

Love Triangle (after Schön), 176 HL94; (Alsatian or Swiss artist), 117 fig. 78, 174 HL86; etching (after Lucas van Leyden), 71 fig. 43, 71, 100, 176 HL92; (Frans Crabbe), 71, 72 fig. 45, 75, 177 HL95; (French artist), 175 HL91; (Graf), 32-33, 33 fig. 6, 59, 87, 93, 97, 98, 100, 108, 115, 173 HL85; (Manuel), 87, 90 fig. 62, 97, 175 HL90; (Master HM), 181 HL106; (Netherlandish artist), 32, 33 fig. 5; (Nuremberg artist), 76 fig. 48, 115, 178 HL98; painting (Lucas van Leyden), 68, 69 fig. 41, 174 HL87; paintings (after Lucas van Leyden), 100, 115, 174 HL88, 175 HL89; (Schön), 75, 76 fig. 49, 77 fig. 50, 115, 178 HL97, 179 HL99, 179 HL100; woodcut (Nuremberg artist), 74 fig. 47, 75, 115, 177 HL96

Lucerne, Fischer Sale ca. 1970, 152 HL 35

Lucretius, 26

Ludicrum drama (Locher), 26

\section{Lustful Old Man Fondling Chicken}

(Master ISD), 50 fig. 23

\section{M}

Macho, Julien, 23

Madrid, Marques de Ariany Collection, 145 HL16

Male and Female Fools (H.S. Beham), 55 fig. 29, 56

Manuel, Niklaus, Love Triangle, 87, 90 fig. 62, 97, 175 HL90; Old Man and Young Woman, 86, 87 fig. 59, 143 HL11; Old Woman and Young Man, 45, 64 fig. 37, 65-67, 98, 167 HL68

Marcolf and Polikana (de Bruyn), 51, 51 fig. 25; (Master bðg), 51, 51 fig. 24

Marie de France, 14-15, 17, 18; compared to Boccaccio, 18; compared with la Tour Landry, 22; compared with Plautus, 18

Massys, Cornelis, 54, 54 fig. 28

Massys, Jan, 106, 146, 147

Massys, Quinten, 68 fig. 40, 68, 69-71, 106, 120, 146 HL18, 169 HL72

Master bxg, 51, 51 fig. 24, 52 fig. 26, 53, 53 fig. 27, 57

Master B R, 56 fig. 30, 57, 59, 65, 67, $113,120,161$ HL55

Master dH, 116, 118 fig. 79, $181 \mathrm{HL}$ 104

Master E.S., 42, 110, 128 n. 110, 143; Fantastic Alphabet, 37-39, 38 figs. 10 and 11; fool in, 101, 128 n. 106, 135 n. 251

Master HM, 181 HL106

Master ISD, 50 fig. 23

Master MZ, 68

Master PW, 113

Master WB, 180 HL101, 180 HL102

Master of the Banderoles, 39, 41 fig. 13, 109, 109 fig. 71

Master of the Love Gardens, 42, 42 fig. 15,128 n. 103

Master of the Playing Cards, 119

Master of the Power of Women, 47, 49 fig. 22, 57, 57 fig. 31

van Meckenem, Israhel, 68, 113; 
Old Man and Young Woman, 139 HL3, 143-45; Old Man with Younger Woman, 88 fig. 60, 145, 164 HL60; Old

Woman and Young Man, 140 HL4, 143-5

Melancholia I (Dürer), 94

Memling, Hans, 57

Menaechmi (Sachs), 26

Miroir de Mariage (Deschamp), 22

Munich, Bayerische Staatsgemäldesammlungen, $150 \mathrm{HL} 29$; von Bissing Collection 1910, 172 HL82; Helbing Auction 1913, 151 HL33; 1907, 160 HL52; J. Scheidwimmer Gallery, 154 HL40; Weinmüller Sale 1974, 158 HL48; 1829, 155 HL43

Murner, Thomas, 27

Myconius, 63 fig. 36, 65

\section{$\mathbf{N}$}

Naked Woman with a Rose (Master of the Power of Women), 57, 57 fig. 31

Narrenbeschwörung ("Exorcism of Fools") (Murner), 27

Narrenschiff (Brant), 34, 50, 52, 65, 75, 107; folly in, 59, 107; "Amours," 47, 48 fig. 21, 88; "Unequal Couple," $27,44,58$ fig. $32,59,60,77,90$

Netherlandish artist, 32-33, 33 fig. 5, 146 HL19, 147 HL20

Netherlands, Private Collection, 114 fig. 75, 181 HL105

New York, American Art AssociationÅnderson Galleries 1936, 159 HL51; Ira Spanierman Gallery, 92 fig. 64, 149 HL27; Lehman Collection, Metropolitan Museum of Art, 175 HL91; Palitz Collection, 170 HL74; Pierpont Morgan Library, 99 fig. 68

Nicholas of Trèves, 26

Nuremberg, Germanisches Nationalmuseum, Cranach Unequal Couple, 80 fig. 53, 151 HL34; Dame Venus, 46 fig. 20,102; Master dH Unequal Couple, 116, 118 fig. 79, 181 HL104

Nuremberg artists, 74 fig. 47, 75, 76 figs. 48 and 49, 77, 93, 93 fig. 65, 106, 107 fig. 70, 115, 177 HL96, 178 HL 97 and 98
Odo of Cheuton, 17

Old Fool and Young Woman (German artist), 181 HL103

Old Fool Embracing Young Woman (van Leyden), 67, 67 fig. 39, 144

HL13

Old Fool Embracing Young Woman with Dog (Master B R), 56 fig. 30, 57, 161 HL55

Old Man and Young Daughter with Antichrist (attributed to Thomas Fröschlein of Reutlingen), 98, 162 HL56; (German artist), 162 HL57

Old Man and Young Wife (Wandereisen), 29-30, 29 fig. 3, 168 HL69

Old Man and Young Woman (Baldung), Liverpool painting, 84 fig. 56, 148 HL25; Karlsruhe painting, 85 fig. 57, 108, 149 HL26; engraving, 86 fig. 58, 115, 116 HL9, 145; (de' Barbari), 95 fig. 66, 97, 141 HL7; (after de' Barbari), 142 HL8; (Cranach the Elder), 79 fig. 52, 80 fig. 53, 83 fig. 55; 146-61 HL nos. 17, 22, 28-32, 34, 36-40, 44-46, 49, 50, 53, 54; (Cranach the Younger), 152-55 HL nos. 35, 41, 42; (School of Cranach the Elder), 147-60 HL nos. 21, 27, 30, 33, 43, 47, 48, 51, 52; (Dü rer), 163 HL59; (The Housebook Master), 41 fig. 14, 88, 90, 139 HL1; (Krodel), 92 fig. 64, 93, 149 HL27; (Manuel), 86, 87 fig. 59, 143 HL11; (Master dH), 118 fig. 79, 181 HL104; (Raimondi), 115 fig. 76, 165 HL62; (Strigel), 91 fig. 63, 98, 120, 164 HL61; (van Meckenem), 139 HL3; (von Kulmbach), 116 fig. 77, 142 HL10

Old Man and Young Woman with Another Young Woman (Cranach school), 172 HL81

Old Man and Young Woman with Two Young Women Nearby (Cranach), 171 HL77

Old Man Embracing Young Woman (Holbein the Younger), 63 fig. 36, 65, 97, 167 HL67

Old Man, Three Young Women, and Two Young Men (Cranach) 172 HL82; 
(Cranach school), 172 HL83

Old Man with Younger Woman (van

Meckenem), 88 fig. 60, 164 HL60

Old Man with Young Woman and

Young Man with Old Woman

(German artist), 61, 62 fig. 35, 143 HL12

Old Man, Young Woman (Master

W B), 180 HL101, 180 HL102

Old Man, Young Woman and Fool (Massys), 68 fig. 40, 106, 120, 146 HL18; (Netherlandish artist), 147 HL20

Old Man, Young Woman and Fool, with Still Life Below (Netherlandish artist), 146 HL19

Old Peasant Couple Carrying Ducks and Eggs (Master bxg), 53, 53 fig. 27

Old Peasant Couple Carrying Loaves of Bread and Jug (Master bxg), 52 fig. 26, 53

Old Wife and Young Fool (Dürer), 58 fig. 32, 163 HL58

Old Wives' Horse Fair (Schön), 123 fig. 82, 171 HL79

Old Woman and Old Fool with Bowl and Jug (Marcolf and Polikana?)

(Master bxg), 51, 51 fig. 24, 57

Old Woman and Old Fool with Bread and Mush (Marcolf and Polikana?) (de Bruyn), 5151 fig. 25

Old Woman and Young Man (attributed to Schweiger), 89 fig. 61, 165 HL63; (Cranach or school), 82 fig. 54, 144 HL14, 145 HL15, 145 HL16; (Hoefnagel), frontispiece, 140 HL5, 141; (Hollar), 140 HL6, 141; (Housebook Master), 120, 121 fig. 80, 139 HL2; (Petrarca Master), 168 HL71; (van Meckenem), $140 \mathrm{HL} 4$

Old Woman and Young Man in Woman's(?) Dress (van Leyden circle), 113, 114 fig. 75, 181 HL105

Old Woman and Young Man, Old Man and Young Woman, Old Man and Young Woman, and Two Young Lovers (Cranach the Younger), 171 HL80

Old Woman and Young Man with Six Onlookers (after Massys), 169 HL72; (attributed to Cranach the Younger),
170 HL75; (circle of Leonardo), 170 HL73, 170 HL76; (Flemish? artist) 170 HL74

Old Woman, Young Man and a Demon (Manuel), 45, 64 fig. 37, 99, 167 HL68, 179

von Olpe, Johann Bergmann, 27

\section{$\mathbf{P}$}

Paphnutius (Hroswitha), 14

Paris, Bibliothèque Natonale, 37 fig. 9

Paris, Charpentier Gallery 1974, 158

HL49

Paris, Private Collection, 171 HL77

Paris(?), 153 HL39

Payment (Cranach), 79, 79 fig. 52, 100, 108, 171 HL78

Peasant and Young Woman (Cranach), 148 HL23, 148 HL24

Penance of St. Chrysostomus (Beham), 110, 110 fig. 72; (Dürer), 110, 111 fig. 73

Petrarca Master (Hans Weiditz), Young Woman Flattering Old Man, 60, 61 fig. 34, 168 HL70; Tree of Fools, 78 fig. 51, 79, 168 HL71

Philadelphia Museum of Art, John G. Johnson Collection, 94, 95 fig. 66, $141 \mathrm{HL} 7$

Picasso, Pablo, 11

Pirckheimer, Willibald, 26

Plautus, Titus Maccius, 11, 13, 19; Boccaccio compared with, 18; Hroswitha compared to, 14, 18, 126 n. 65; Marie de France compared with, 18 ; revival of, 26,34

Prague, Rudolphinum, 152 HL37, 153 HL38

Praise of Folly (Erasmus), 13, 28, 31; folly in, 61-65, 69; Unequal Couples, $61-63,63$ fig. $36,65,68-70$

Private Collection, 116, 116 fig. 77, 142 HL10

Prodial Son(?) in a Tavern (van Leyden), 70 fig. 42, 71, 146, 176

\section{$\mathbf{R}$}

Raimondi, Marcantonio, 115, 115 fig. 76, 165 HL62 
Rastell, John, 30

Rederijker (rhetoricians), 29, 30, 69

Regensburg, Rathaus, 102, 105 fig. 69

Der Renner (Austrian artist), 97, 99

fig. 68

Repast in a Bathhouse (Franco-Flemish artist), 40 fig. 12

Reuchlin, Johannes, 26

Rhenish artist, 46 fig. 20, 102; Dame

Venus Choosing Between Gentle-

man and Burgher with Money

Sack, 102, 105 fig. 69

Richmond, Virginia Museum, 181 HL103

Ritter vom Turn (la Tour Landry), 20-22

Roman de la Rose (de Lorris and de Meun), 15-16, 49

Gesta romanorum, 17-18

\section{S}

Sachs, Hans, 26, 31-33, 34, 94, 171

Saint Bernardino, 17

Die Schelmenzunft ("Guild of Rogues") (Murner), 27

Schön, Erhard, Anamorphic Love

Triangle, 71, 72 fig. 44, 87, 115, 176 HL93; Cage of Fools, 121, 122

fig. 81; Horsemarket of Women, 123, 123 fig. 82, 171 HL79; Love Triangle playing card, 75, 77 fig. 50, 179

HL99; Love Triangle with Chastity

Belt and Key, 75, 76 fig. 49, 115, 178 HL97; Love Triangle with Harp and Dog, $179 \mathrm{HL100}$; attribution to Love Triangle, 75; after, 176 HL94

Schongauer, Martin, 67

Schweiger, Jörg, attributed to, 86,89

fig. 61, 165 HL63

Seventh Commandment (Strasbourg

artist), 42, 43 fig. 16

Shakespeare, William, 30

Ship of Fools. See Narrenschiff

Sibiu, Rumania, 151 HL32

Small Garden of Love (Master of the Love Gardens), 42, 42 fig. 15, 128 n. 103

Smith Collection, 170 HL73, 170 HL76

Solis, Virgil, 32

Sorg, Anton, 45

Steinhöwel, Heinrich, 23
Stockholm, National Museum, 79 fig. 52, $81,100,171$ HL78

Van Stout ende Onbescaemt ("Of the Naughty and Unashamed") (Everaert), 31

Strasbourg artist, 43 fig. 16, 42-45

Strigel, Bernhard, 86, 91, fig. 63, 98, 108, 120, 164 HL61

Summa Predicantium (Bromyard), 16

Susannah and the Elders (Altdorfer), 110

\section{$\mathbf{T}$}

Tales, humorous (Schwankerzahlungen), 24-26

Tapestry, 46 fig. $20,47,106$

Ten Commandments (Cranach), 45, 45 fig. 19

Terence, 26, 52

de la Tour Landry, Chevalier, 20-22

Traut, Wolf, 26

Tree of Fools (attributed to Leu or the Petrarca Master), 78 fig. 51, 79, 168 HL71

von Trimberg, Hugo, 97

\section{$\mathbf{U}$}

Unkeuschheit ("Lechery"), 96 fig. 67, 97

\section{V}

Valerius Maximus, 36

Van die valsche ontrouwe Liefte ("Of False, Untrue Love") (Netherlandish artist), 32-33, 33 fig. 5

Vanity (Memling), 57

Vienna, Akademie der bildenden Künste, 156 HL45; Albertina, frontispiece, 140 HL5; Art Market, formerly, 169 HL72; Ball and Graupe 1920, 156 HL44; Bondy Collection, 159 HL50; Figdor Collection, formerly, 117 fig. 78, 174 HL86; Kunsthistorisches Museum, 160 HL53; Oesterreichische Nationalbibliothek, 36

de Vitry, Jacques, 17

Vogtherr, Heinrich, 75 
Wandereisen, Hans, 29-30, 29 fig. 3, 168 HL69

Warsaw, National Museum, 157 HL46

Washington, National Gallery, 68 fig.

40, 146 HL18

Weiditz, Hans. See Petrarca Master

Wittenberg, Lutherhalle, 45, 45 fig. 19

"Wives and Widows" (St. Bernardino), 17

Woenende, Pieter Warnersz., 32

Women with Long Hair and Short Wits (Austrian artist), 97, 99 fig. 68

Wycherley, William, 11

$\mathbf{Y}$

Young Woman Flattering Old Man

(Petrarca Master), 60, 61 fig. 34, 168 HL70

Young Woman Selling Spectacles to Old Man and Young Man Embracing Old Woman, with a Fool (Cornelisz. van Amsterdam), 59, 60 fig. 33, 166 HL64; (after Cornelisz. van Amsterdam), 166 HL65, 166 HL66

\section{$\mathbf{Z}$}

Zweierlei Ungleiche Ehen ("Two Unequal Marriages") (Sachs), 31-33

A J. Burt Totaro production 